UNIVERSIDADE DE SÃO PAULO

ESCOLA DE COMUNICAÇÕES E ARTES

ILANA FELDMAN MARZOCHI

\title{
JOGOS DE CENA: \\ ENSAIOS SOBRE O DOCUMENTÁRIO BRASILEIRO CONTEMPORÂNEO
}

SÃo PAULO

2012 


\section{Jogos de cena: \\ Ensaios sobre o documentário brasileiro contemporâneo}

Tese apresentada ao Programa de Pós-Graduação em Ciências da Comunicação da Escola de Comunicações e Artes da Universidade de São Paulo, como requisito parcial para obtenção do título de Doutor. Área de concentração: Estudo dos Meios e da Produção Mediática.

Orientador:

Prof. Dr. Ismail Norberto Xavier

SÃO PAULO, 2012 
Autorizo a reprodução e divulgação total ou parcial deste trabalho, por qualquer meio convencional ou eletrônico, para fins de estudo e pesquisa desde que citada a fonte.

\section{Catalogação na publicação Serviço de Biblioteca e Documentação \\ Escola de Comunicações e Artes da Universidade de São Paulo}

Marzochi, Ilana Feldman

Jogos de cena : ensaios sobre o documentário brasileiro contemporâneo / Ilana

Feldman Marzochi - São Paulo : I. F. Marzochi, 2012. $162 \mathrm{p}$.

Tese (Doutorado) - Escola de Comunicações e Artes / Universidade de São Paulo.

Orientador: Ismail Norberto Xavier

1. Documentário - Brasil - Século 21 2. Ensaio 3. Autoficção 4. Performance 5. Indeterminação 6. Imagens amadoras 7. Efeitos do real 8. Coutinho, Eduardo, 1933- I. Título II. Xavier, Ismail Norberto

CDD 21.ed. - 791.43530981 


\section{FOLHA DE APROVAÇÃO}

\section{Jogos de cena:}

Ensaios sobre o documentário brasileiro contemporâneo

Ilana Feldman Marzochi

Tese apresentada ao Programa de Pós-Graduação em Ciências da Comunicação da Escola de Comunicações e Artes da Universidade de São Paulo, como requisito parcial para obtenção do título de Doutor. Área de concentração: Estudo dos Meios e da Produção Mediática.

Aprovado em:

Banca examinadora:

Prof. Dr:

Instituição:

Assinatura:

Prof. Dr:

Instituição:

Assinatura:

Prof. Dr:

Instituição:

Assinatura: 
Prof. Dr:

Instituição:

Assinatura:

Prof. Dr:

Instituição:

Assinatura: 


\section{RESUMO}

Ensaísmo, práticas confessionais, autoficção, performance de si, apropriação de imagens amadoras, valorização do processo e abertura da cena à sua não-realização, na forma da emergência do fracasso, são escolhas, projetos ou procedimentos estéticos empregados em um número crescente de filmes brasileiros, sobretudo aqueles tomados por documentais. Tais escolhas dialogam, criticamente ou não, com uma cultura audiovisual colonizada por estratégias que visam a uma permanente intensificação dos "efeitos de real": seja por meio da tentativa de apagamento da linguagem como construção e mediação (o que chamamos de "apelo realista"), seja por meio da exposição de uma suposta intimidade como lugar privilegiado, ou mesmo garantia, da verdade do sujeito (o que chamamos de "hipertrofia da subjetividade"). Na contramão dessa tendência e operando na indeterminação entre autenticidade e encenação, pessoa e personagem, público e privado, processo e obra, experiência e jogo, vida e performance, diversos documentários brasileiros contemporâneos, que constituem o foco de nosso interesse, têm investido na opacidade, na explicitação das mediações, na reposição da distância e na tensão entre as subjetividades e seus horizontes ficcionais - destilando dúvidas a respeito da imagem documental, colocando sob suspeita seus procedimentos ou produzindo suas próprias esquivas. Os filmes que constituem o nosso corpus - caso de Jogo de cena (Eduardo Coutinho, 2007), Santiago (João Moreira Salles, 2007), Pancinema permanente (Carlos Nader, 2008), Juízo (Maria Augusta Ramos, 2008), Filmefobia (Kiko Goifman, 2009), Moscou (Eduardo Coutinho, 2009), Sábado à noite (Ivo Lopes Araújo, 2007), O céu sobre os ombros (Sergio Borges, 2010), Pacific (Marcelo Pedroso, 2009), Rua de mão dupla (Cao Guimarães, 2004), Avenida Brasília Formosa (Gabriel Mascaro, 2010) e Viajo porque preciso, volto porque te amo (Marcelo Gomes e Karim Ainouz, 2009), além de diversos outros títulos, de longas e curtas-metragens, a eles relacionados - não são aqui vistos como meros sintomas de nossa época, nem como formas puramente autônomas dotadas de legitimidade artística. Organizados em quatro ensaios e articulados a outras manifestações da cultura, os filmes analisados tanto constituem diversos regimes de visibilidade (com seus correlatos modos de produção da subjetividade) como tensionam as formas estéticas e as forças culturais, políticas e sociais em jogo em nossa sociedade mediada pela imagem, onde o que se mobiliza e disputa é a própria vida ordinária (que sempre interessou ao documentário), contígua às dinâmicas do capital e indissociável de seus jogos de cena.

Palavras-chave: 1. Documentário brasileiro contemporâneo; 2. Ensaio; 3. Autoficção; 4. Performance; 5. Indeterminação; 6. Imagens amadoras; 7. Efeitos de real; 8. Coutinho, Eduardo 


\begin{abstract}
Filmic essays, confessional practices, autofiction, performance of the self, appropriation of amateur images, appreciation of the creative process and the openness of the scene to its non-closure assuming a sense of failure: these are all choices, projects or aesthetic procedures employed by a growing number of Brazilian films, especially those classified as documental. These choices dialogue, critically or not, with an audiovisual culture colonized by strategies that aim the constant intensification of "reality effects". These effects are achieved either by the attempt of erasing filmic language as a construction and as a mediation process (what we name "realist appeal"), or by means of exposing an alleged intimacy as the place of the subject's guaranteed truth (what we name "subjectivity hypertrophy"). Heading towards another direction, a number of Brazilian contemporary documentaries work within an undetermined zone between the authentic and the staged, the real subject and the fictional character, the public and the private sphere, the artistic process and the final work, the real experience and the invented game, life and performance. These films, which will be the main focus of our interest, invest in the opacity of meaning, in the self-evidence of the filmic mediations as well as the reenactment of distances and tensions between subjects and their fictional counterparts, raising questions about the status of the documental image and putting their own artistic procedures under scrutiny. The films chosen for our analysis - Playing (Eduardo Coutinho, 2007), Santiago (João Moreira Salles, 2007), Permanent Pancinema (Carlos Nader, 2008), Behave (Maria Augusta Ramos, 2008), Filmphobia (Kiko Goifman, 2009), Moscow (Eduardo Coutinho, 2009), Saturday night (Ivo Lopes Araújo, 2007), The sky above (Sergio Borges, 2010), Pacific (Marcelo Pedroso, 2009), Two way street (Cao Guimarães, 2004), Avenida Brasília Formosa (Gabriel Mascaro, 2010) e I travel because I have to, I come back because I Love you (Marcelo Gomes e Karim Ainouz, 2009) and many other short and feature films - are not seen as symptoms of our time neither as purely autonomous forms with artistic legitimacy. Organized in four essays, the films are analyzed in combination with other cultural manifestations creating different visibility regimes (each one with its own mode of subjectivation) and tensions within the aesthetic forms and the cultural forces - a political and social quarrel at play in our society permeated by images - in which the place of dispute is a theme that always interested documentarists: the ordinary life, always connected to the dynamics of capitalism and inseparable from its scenic games.
\end{abstract}

Key-words: 1. Brazilian contemporary documentary; 2. Essay; 3. Autofiction; 4. Performance; 5. Indetermination; 6. Amateur images; 7. Reality effects; 8. Coutinho, Eduardo 
a Ismail Xavier, pela confiança, generosidade e clareza "republicana" do pensamento, sempre atento em seus preciosos comentários críticos e sempre disposto a encarar o fugidio contemporâneo.

a Cleber, pelo estímulo constante, pela crítica alerta, pela contundência afetiva na vida a dois e por tudo quanto não se pode dizer.

aos professores que tomaram parte de meu exame de Qualificação, Vladimir Safatle e Cristian Borges, pelas observações precisas e valiosas.

aos queridos amigos e interlocutores fundamentais nesse processo, Cezar Migliorin, André Brasil e Claudia Mesquita; a Simone Paterman, pela duradoura partilha afetivaintelectual mesmo à distância e pelo tão caloroso quanto fundamental acolhimento em Paris; também a Max Eluard e ao pessoal do programa DOCTV, por terem, sem o saber, me levado a outros caminhos.

a Rosely e a todas as moças que trabalham na secretaria do PPGCOM, Ivete, Elaine, Miriam, Valnete....

a CAPES, pelo auxílio financeiro concedido durante os quatro anos de pesquisa e pela bolsa PDEE, que possibilitou meu estágio de doutorado na Universidade de Paris 8.

por fim, mas sendo o início de tudo, a meus pais, Keyla e Mauro, e a meus irmãos, Samira e Saulo, pelas mãos sempre e firmemente dadas, assim como por todos os exemplos de coerência, integridade e dedicação à coisa pública. 
E não me esquecer, ao começar o trabalho, de me preparar para errar. Não esquecer que o erro muitas vezes se havia tornado meu caminho (...), pois só quando erro é que saio do que conheço e do que entendo.

G.H / Clarice Lispector A paixão segundo G.H 


\section{SUMÁRIO}

Apresentaçã 0 ...................................................................................................................................11

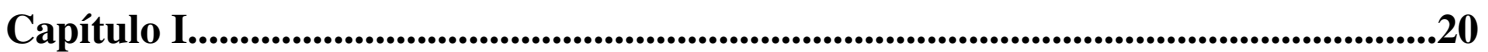

Na contramão do confessional

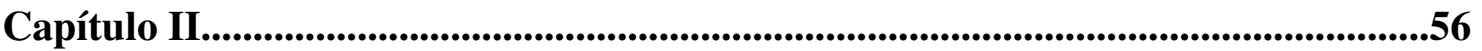

A indeterminação sob suspeita

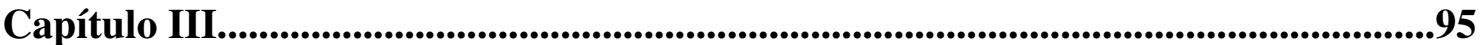

O trabalho do amador

Referências bibliográficas...................................................................................................................145 


\section{APRESENTAÇÃO \\ Jogos de cena: ensaios sobre o documentário brasileiro contemporâneo}

\section{Privilégio do contemporâneo}

Marcado pela diversidade temática e heterogeneidade de propostas estéticas, a produção de filmes documentários, ou de forte efeito documental, realizada atualmente no país só nos permite uma visão de conjunto caso façamos algumas escolhas e recortes. Eleger os últimos cinco anos, de 2007 até os dias atuais, para circunscrever um panorama, apontando tendências, tensões e pontos de contato dentre uma produção cuja multiplicidade aparentemente impediria articulações de sentido, é o desafio e risco de um pensamento que deseja evocar e problematizar o documentário brasileiro contemporâneo, sem perder de vista as relações, os atravessamentos e as contaminações dessa produção com as mais diversas manifestações midiáticas e culturais.

Privilegiar o contemporâneo, entretanto, não significa fazer-se coincidir com sua época, como poderia parecer, mas estabelecer uma singular relação com o próprio tempo, que adere a este na medida em que dele toma distância, por meio de recortes, escolhas e perspectivas. Segundo o filósofo italiano Giorgio Agamben ${ }^{1}$, aqueles que coincidem muito plenamente com sua época, que em todos os aspectos a ela aderem, não são contemporâneos, porque, exatamente por isso, não conseguem vê-la, não conseguem fixar o olhar sobre ela. Privilegiar o contemporâneo, portanto, significa acolher para si as contingências, a opacidade e os limites de nossa capacidade de compreensão, sem dúvida parcial e lacunar. Como já postulara Hannah Arendt, para quem compreender significava um radical engajamento no presente - "encarar a realidade sem preconceitos e com atenção, e resistir a ela, qualquer que seja"2 -, nós somos contemporâneos somente até o ponto em que chega nossa compreensão ${ }^{3}$.

\footnotetext{
${ }^{1}$ AGAMBEN, Giorgio. Qu'est-ce que le contemporain? Paris: Payot \& Rivages, 2008.

2 ARENDT, Hannah. As Origens do Totalitarismo. São Paulo: Cia das Letras, 1989, p.12

${ }^{3}$ ARENDT, Hannah. Compreensão e Política, Lisboa: Relógio D’água, 1993, p.53
} 
Ressalva feita e risco assumido, é preciso lançar-se à aventura de compreender o momento escolhido. De modo geral, o ano de 2007 foi marcado por alguns movimentos expressivos do cinema brasileiro, quando tivemos, sobretudo no campo do documentário, um recorde de lançamento de filmes de diretores estreantes, sinal explícito do impacto do vídeo digital tanto na captação quanto na projeção de filmes de baixo-orçamento em salas de cinema também equipadas com projetores digitais; quando tivemos o filme-evento Tropa de elite, de José Padilha, o maior sucesso de público do cinema brasileiro das últimas décadas (se levarmos em conta os números extra-oficiais da pirataria de que o filme foi alvo antes de seu lançamento comercial), sustentado pelas "retóricas do real" e por uma estética de forte impacto "realista"; e quando o lançamento de filmes documentais em circuito comercial constituiu, naquele ano, cerca de $50 \%$ do lançamento de filmes brasileiros, contexto em que se destacaram, com enorme repercussão crítica, os ensaios documentais Jogo de cena, do já veterano diretor Eduardo Coutinho, e Santiago, do já consagrado João Moreira Salles.

Como veremos adiante, Jogo de cena, de Coutinho, desempenha aqui um papel de filme-solar, em torno do qual gravitam diversos outros filmes de grande interesse e problemas que nos são fundamentais, assim como objetos midiáticos e manifestações culturais: conjunto que constitui a nossa constelação, cujas partes entram em relação pela diferença e não por uma pretensa unidade e cuja força de gravidade emana do presente.

\section{$O$ apelo realista}

Os movimentos acima elencados nos permitem traçar algumas características importantes do cinema brasileiro contemporâneo, no âmbito do qual se situa a produção documental. Para além do fato de que o cinema brasileiro é um cinema cada vez mais jovem, no sentido da quantidade de cineastas estreantes que não necessariamente se encontram no eixo Rio-São Paulo e que não necessariamente serão assimilados pelo "mercado" (cineastas cujos filmes comparecem em nossas análises), temos tido, em projetos mais comerciais, um investimento significativo em filmes que, tal como Tropa de elite, apelam constantemente à produção e dramatização da realidade, renovando seus códigos realistas e intensificando seus efeitos de real - quando a linguagem, 
segundo Roland Barthes, desapareceria como mediação para surgir confundida com as coisas, em que é o próprio real que parece "falar"4.

Indissociáveis de um regime de visibilidade pautado pela construção e intensificação de efeitos de real cada vez mais pregnantes, como indica a proliferação de reality shows, imagens amadoras apropriadas pelo telejornalismo, acontecimentos nãoficcionais incorporados pela teledramaturgia e toda sorte de flagras picantes, flagrantes policiais e vídeos caseiros disponíveis na internet, inúmeros títulos do cinema brasileiro recente que seguem essa tendência vinculam-se ao que chamamos de "apelo realista", cujo efeito estético visa uma tentativa de apagamento das mediações (ou seja, o acesso a experiências supostamente "diretas", "não-mediadas" ou "imediatas") e cujo efeito político pauta-se pela tentativa de legitimação, naturalização e desresponsabilização dessas narrativas e imagens.

Oferecidas pelos produtos "baseados em fatos reais" e pelo mercado dos testemunhos autobiográficos, ancorados na "exposição da intimidade" como lugar privilegiado (ou mesmo garantia) da verdade dos sujeitos, essas operações narrativas, junto às dinâmicas do capitalismo contemporâneo, identificado por diversos autores como "imaterial", "biopolítico", "conexionista" ou "pós-industrial”, têm deslocado a vida cotidiana e a experiência estética para o centro de seus investimentos, apelando constantemente às "retóricas do real" e à inflação do "confessional-midiático". Em meio a tal panorama, em que obras de ficção buscam sua legitimação e autorização prévias na reconstrução ou representação de fatos de nossa história recente e de personagens preexistentes (personagens esses freqüentemente empreendedores, quando não predestinados), caso de tantos filmes "bem-sucedidos" em matéria de cifras e público, assistimos no cenário do documentário brasileiro contemporâneo a um movimento contrário, na contramão do confessional e dos efeitos de real.

Nesse contexto, tal regime de "transparência narrativa" é questionado, problematizado e colocado sob suspeita pela constelação de filmes que constituem o corpus de nossas análises, em uma espécie de prática a contrapelo face ao que é

\footnotetext{
${ }^{4}$ BARTHES, Roland. "O efeito de real". In: O rumor da língua. São Paulo: Martins Fontes, 2004.

${ }^{5}$ Cf. nosso trabalho, FELDMAN, Ilana. "O apelo realista". In: Revista FAMECOS, "Dossiê Menções de Destaque - Compós 2008”, Porto Alegre, n.36, ago. 2008.
} 
dominante. Assim, insurgindo-se contra a realidade imediata prometida pelo apelo realista ou contra os artificialismos de um cinema brasileiro esteticamente conservador, televisivo e "novo rico", caso de comédias de costumes e de filmes, freqüentemente, já pensados como franquia, a produção documental brasileira pode nos dar a ver, às avessas, a impossibilidade de se chegar ao "real" ou de se falar em nome dele.

Acolhendo em suas escrituras a consciência de seus limites, a linguagem como defasagem e subtração, a cena como espaço de solidão e não-realização e a própria separação (do personagem para consigo e do personagem para com o outro, o realizador) como condição mesma de toda relação, o documentário pode enfim nos dar a ver o contracampo da "era da performance" em que vivemos, pautada pela otimização do desempenho (seja social, pessoal ou profissional) e pelas mitologias de autorealização bem sucedida. O documentário, esse campo "menor" e indeterminado (ou potencialmente liberto de toda prévia determinação), pode enfim nos dar a ver a distância como condição da mediação, o fracasso como possibilidade de criação e o desencontro como condição dos sujeitos, habitantes do mundo da linguagem, porém nunca perfeitamente contidos nele.

\section{Sob o risco do real, sob o risco da ficção}

$\mathrm{Na}$ contramão, portanto, dessa tendência realista que tem pautado o cinema de ficção e operando na indeterminação entre autenticidade e encenação, pessoa e personagem, público e privado, intimidade e visibilidade, processo e obra, experiência e jogo, vida e performance, diversos documentários brasileiros contemporâneos, que constituem o foco de nosso interesse, têm investido na opacidade, na explicitação das mediações, na reposição da distância e na tensão entre as subjetividades e seus horizontes ficcionais - destilando dúvidas a respeito da imagem documental, colocando sob suspeita seus próprios procedimentos, métodos e premissas ou produzindo suas próprias esquivas.

Nesse panorama em que, grosso modo, a ficção se documentariza e documentário se ficcionaliza, isto é, em que os protocolos documentais (o trabalho com não-atores ou atores-amadores em seus ambientes reais) são atravessados por recursos expressivos da ficção (a reencenação e a decupagem das situações, a recriação de 
personagens, a montagem narrativa, por vezes o uso de trilha sonora não-diegética etc.) e vice-versa, os trânsitos entre a ficção e o documentário estão, de maneira inédita, tanto na pauta do audiovisual contemporâneo quanto no âmbito da própria vida cotidiana, atravessada por todo tipo de imagens, dispositivos e tecnologias. Em tal contexto de flagrante indeterminação, em que, de um lado, se vive a realidade como artifício e o artifício como realidade, de outro, a ascensão das práticas documentais parece responder ao "espetáculo" generalizado, quando o que se mobiliza e disputa é a performance mais autêntica, a confissão surpreendente, a capacidade de empatia e espontaneidade de todo tipo de personagem, seja anônimo, seja celebridade.

Se a exigência da performance converteu-se em um imperativo imanente ao corpo social, contexto no qual, diria o crítico francês Jean-Louis Comolli, a mise en scène se torna um fato social, "talvez $o$ fato social principal", o documentário brasileiro contemporâneo, cada vez mais reflexivo, engajado e distanciado, afeito à cena, às práticas autoficcionais e à teatralidade, nos leva a pensar: o que eu vejo na tela? Realidade, verdade, manipulação, ficção ou tudo ao mesmo tempo? Como bem nos alertam Consuelo Lins e Claudia Mesquita ${ }^{7}$, essas questões, de acordo com Jean-Louis Comolli, pertenciam apenas ao cinema, mas, diante de um mundo-espetáculo em que vivemos, se transformaram em questões que dizem respeito a todos nós.

Lugar indefinido, gênero indeterminado (o que não significa postular a total indistinção entre ficção e documentário, como bem ressalvam César Guimarães e Rubens Caixeta $^{8}$ ), campo de forças plurais e práticas distintas, e, enfim, nome de uma multiplicidade, de uma suspeita e de uma "liberdade", como o define Cezar Migliorin", o documentário brasileiro contemporâneo constitui nosso corpus e nosso problema, mesmo quando, no âmbito do recorte proposto, têm-se ficções de forte efeito ou apelo documental.

\footnotetext{
${ }^{6}$ COMOLLI, Jean-Louis. "Retrospectiva do espectador". In: Ver e poder: a inocência perdida - cinema, televisão, ficção, documentário. Belo Horizonte: UFMG, 2008, p.98.

7 LINS, Consuelo; MESQUITA, Cláudia. Filmar o real - sobre o documentário brasileiro contemporâneo. Rio de Janeiro: Jorge Zahar, 2008, p.82.

8 GUIMARÃES, César; CAIXETA, Rubens. "Pela distinção entre ficção e documentário (provisoriamente)". In: COMOLLI, Jean-Louis. Ver e poder: a inocência perdida - cinema, televisão, ficção, documentário. Belo Horizonte: UFMG, 2008.

9 MIGLIORIM, Cezar. "Documentário recente brasileiro e a política das imagens". In: MIGLIORIN, Cezar (org.) Ensaios no real. Rio de Janeiro: Azougue, 2010, p.9.
} 
Dito isso, formam nossa principal constelação os filmes Jogo de cena (Eduardo Coutinho, 2007), Santiago (João Moreira Salles, 2007), Pan-cinema permanente (Carlos Nader, 2008), Juízo (Maria Augusta Ramos, 2008), Filmefobia (Kiko Goifman, 2009), Моsсои (Eduardo Coutinho, 2009), Sábado à noite (Ivo Lopes Araújo, 2007), O céu sobre os ombros (Sergio Borges, 2010), Pacific (Marcelo Pedroso, 2009), Avenida Brasília Formosa (Gabriel Mascaro, 2010), Viajo porque preciso, volto porque te amo (Marcelo Gomes e Karim Ainouz, 2009) e Rua de mão dupla (Cao Guimarães, 2004), o único filme anterior ao ano de 2007, além de diversos outros títulos, de longas e curtasmetragens, a eles relacionados e articulados.

Nem meros sintomas de nossa época, nem formas puramente autônomas dotadas de legitimidade artística, os filmes que nos interessam como foco de análise, em cotejo com outras manifestações midiáticas e culturais, estão organizados em quatro ensaios ("Na contramão do confessional", "A indeterminação sob suspeita", "O trabalhador do amador" e "O êxito do fracasso"), filiando-se a escolhas, práticas e procedimentos diversos: como ensaísmo, práticas confessionais, autoficção, performance de si, apropriação das imagens amadoras, valorização do processo e abertura da cena à sua não-realização, na forma do fetiche do acaso ou da emergência do fracasso.

Ao constituírem, desse modo, diversos regimes de visibilidade, com seus correlatos modos de produção da subjetividade, as obras que constituem nosso recorte é fundamental ressaltar - são providas de uma força de invenção de seus próprios problemas, enfrentando impasses diversos e tensionando as formas estéticas às forças culturais, políticas e sociais em jogo em nossa sociedade mediada pela imagem, onde o que se mobiliza e disputa é a própria vida ordinária (que sempre interessou ao documentário), contígua às dinâmicas do capital e indissociável de seus jogos de cena.

\section{Documentário como jogo de cena?}

A partir da centralidade ocupada pelo filme Jogo de cena (2007), de Eduardo Coutinho, espécie de objeto-solar que ilumina a constelação de objetos a cima elencados, cada uma das obras focalizadas, cada qual a seu modo e na sua intensidade, cultiva incertezas e desconfianças por todo o filme. Assim, se as obras destilam dúvidas 
a respeito da imagem documental, perturbam a crença do espectador naquilo a que se está assistindo e estilhaçam as noções de autêntico, verdadeiro e espontâneo, tão comumente remetidas ao campo do documentário, elas também solicitam do espectador outro tipo de engajamento e de posição. Com isso, caberia perguntar, como o faz pertinentemente Ismail Xavier, "reconhecimento definitivo do documentário como jogo de cena?"10

Considerado um filme-ensaio ou um ensaio-fílmico, Jogo de cena coloca sob suspeita os filmes documentários baseados na fala como expressão da subjetividade e como relato testemunhal de histórias de uma vida. Ao por em dúvida a relação de propriedade entre o corpo falante e a fala pessoal, supostamente intransferível (a quem pertence essa fala? Quem a emite? E ela fala sobre o quê?), Jogo de cena acabaria, portanto, como acredita Jean-Claude Bernardet, nos comentários disponibilizados em seu blog na internet ${ }^{11}$, por inviabilizar a prática da entrevista - isto é, acabaria por inviabilizar a crença corrente na entrevista como expressão da verdade dos personagens (marca da filmografia de Eduardo Coutinho desde Santo Forte, 1997) -, assim como por desestabilizar a própria noção de sujeito.

Operando no âmbito da linguagem cinematográfica uma importante mediação entre cultura, sociedade, sujeito e política, o ensaísmo documental tem se mostrado, não sem ambigüidades e problemas, cada vez mais potente e instigante face à profusão dos "efeitos de real" e à eloqüência do "confessional-midiático". Por meio do ensaísmo, ou dos gestos a ele avizinhados, trata-se de achar e repor a distância justa, precisa, adequada, para que a inadequação dos sujeitos ao mundo, para que a defasagem entre a experiência e a imagem, possam enfim reconfigurar e perturbar certa ordem consensual do visível. É a contagiosa instabilidade, indeterminação ou opacidade inerente ao ensaio o que proporcionará, portanto, os trânsitos e as passagens entre o singular e o coletivo, o privado e político, a memória e a atualidade, a vida privada e sua historicidade - que não se desvincula do lugar e da função do cinema.

\footnotetext{
${ }^{10}$ XAVIER, Ismail. "Indagações em torno de Eduardo Coutinho e seu diálogo com a tradição moderna". In: MIGLIORIN, Cezar (org.) Ensaios no real. Rio de Janeiro: Azougue, 2010, p.67.

${ }^{11}$ BERNARDET, Jean-Claude. "Jogo de cena", 14/01/2008. Disponível no "Blog do Jean-Claude", em: http://jcbernardet.blog.uol.com.br/
} 
De outro lado, privilegiar objetos de inclinação ensaística ou reflexiva, isto é, privilegiar a reposição da distância, não significa trabalhar na chave do modernismo, seja em relação às obras, marcadas por narrativas de desvelamento de seus próprios modos de produção, seja em relação às críticas a elas endereçadas, marcadas pela valorização desse "distanciamento", como se tal protocolo prescindisse da própria atividade crítica a ele exterior. Antes, como sugere Vladimir Safatle em entrevista intitulada "Envelhecimento do moderno"12, para reformular o pensamento no campo das artes deve-se partir do pressuposto de que há uma forma crítica, baseada em certa dinâmica de desvelamento, que esgotou sua função, porque a própria realidade social a ultrapassou. Como arremata Safatle, "a própria realidade social já opera esse desvelamento, pois é auto-irônica".

\section{Metodologia herege}

Uma das formas para enfrentarmos essa dificuldade que se apresenta baseia-se na defesa metodológica de um modo de pensar imposto pelas condições de existência dos objetos, objetos que, no lugar do distanciamento crítico de outrora, nos impelem a um engajamento crítico e afetivo. Para tanto, optamos pelo pares dípticos, pelos conjuntos e pelos filmes como "dobradiças", partindo da premissa de que não se pode exaurir uma relação com o objeto nem tiranizá-lo com descrições exclusivamente pormenorizadas, já que os filmes invariavelmente resistem (ou precisariam resistir) aos conceitos a eles cotejados. Orientamo-nos então pela idéia de que em cada capítulo (ou ensaio) os filmes possam comparecer e ser acionados de maneiras diferentes, a partir de distintas metodologias de abordagem e de distintos problemas teóricos, em uma construção dotada de relativa autonomia.

A partir desses movimentos, é então possível que um "mesmo" filme retorne em mais de um capítulo, mas de maneiras diversas, configurando uma espécie de "eterno retorno do diferente". Sendo assim, fica evidente que não são os objetos "singulares", mas as relações que forjam um recorte, colocam limites e delimitam perspectivas. O que importa, portanto, não são as obras em "si mesmas", mas as relações críticas e afetivas

\footnotetext{
${ }^{12}$ SAFATLE, Vladimir. "O envelhecimento do moderno". Entrevista concedida a Juliano Gentile e Thais Rivitti, em 05/01/2007. http://forumpermanente.incubadora.fapesp.br/portal/.rede/numero/rev-numero6/
} 
que podemos, contingencialmente, estabelecer com elas. Nesse sentido, sem perder de vista o cotejo com uma cultura pré-formada, fetichizada, muitas vezes resistente à análise crítica, será também privilegiado o diálogo com uma constelação de objetos tangenciais que nos são contemporâneos, objetos mais sintomáticos ou, por assim dizer, "mundanos". Afinal, a lei formal mais profunda do ensaio, como postulava Adorno ${ }^{13}$, é a heresia.

Por fim, mas sendo o início de tudo, é preciso, com todo o esforço de análise e entendimento em jogo, defender o caráter inacabado de alguns conceitos (tais como performance, autoficção, imagens amadoras, indeterminação). Resguardar seu inaudito. Mobilizar sua opacidade e força plástica. Pois é tal força que, ao os fazerem escapar permanentemente, nos movem e movem o pensamento - até o limite de nossa compreensão.

${ }^{13}$ ADORNO, Theodor. "O ensaio como forma". In: Notas de Literatura I. São Paulo: Editora 34 e Duas Cidades, 2003, p. 45. 
CAPíTULO I 


\section{Na contramão do confessional: \\ Jogo de cena (Eduardo Coutinho, 2007) e Santiago (João Moreira Salles, 2007)}

\section{Metodicamente sem método: ensaísmo e mediação}

Ensaísmo, práticas confessionais e autoficção são escolhas e procedimentos estéticos empregados em um número crescente de filmes brasileiros, sobretudo aqueles tomados por documentais. Tais escolham dialogam, criticamente ou não, com uma cultura audiovisual colonizada por estratégias que visam à intensificação dos efeitos de verdade, seja por meio da apropriação e captura das velhas marcas da reflexividade, tomada agora como indicialidade testemunhal (como rastros da filmagem, presença da equipe, tematização do dispositivo, explicitação da câmera), seja por meio do investimento na exposição de uma suposta intimidade como lócus privilegiado, ou mesmo garantia, da verdade do sujeito (a partir de toda sorte de estratégias confessionais-midiáticas).

Na contramão dessa cultura audiovisual sintomática, mas sem perder de vista seus pontos de contato, alguns filmes brasileiros contemporâneos aderem ao ensaísmo ou ao filme ensaio, escovando a contrapelo a busca pelo efeito de verdade pautado tanto por estratégias outrora reflexivas quanto por práticas confessionais. Para tanto, investem na opacidade, na explicitação das mediações, na tensão entre as subjetividades e seus horizontes ficcionais e na problematização das próprias prerrogativas, destilando dúvidas a respeito da imagem documental, colocando sob suspeita seus procedimentos ou produzindo suas próprias esquivas.

Em um momento em que as demarcações de gênero têm perdido sua vigência e as tradicionais clivagens que pavimentam nosso sistema de pensamento, como transparência/opacidade, clássico/moderno, natureza/artifício, autenticidade/encenação, dentre outras, têm sido, se não dissolvidas, repostas em outros termos, Ismail Xavier sintetiza em recente entrevista, "a noção de filme ensaio abriria um novo caminho para repensar as articulações entre o que a tradição chama de ficção e de documentário" 
(2009: 286). Filiando-se assim a uma espécie de ensaísmo documental, "gênero" sempre inadequado, fugidio e, como defenderemos aqui, indeterminado, os filmes Santiago (João Moreira Salles, 2007) e Jogo de cena (Eduardo Coutinho, 2007), foco de nosso interesse, fazem da explicitação e problematização do próprio método, não sem a sedução emocional do espectador, o tema e a estrutura desse reflexivo e, simultaneamente, afetivo jogo-cinema.

Distante então da imediatez de certo regime de visibilidade contemporâneo marcado por um apelo realista (Feldman, 2008) e pautado por um ideal de "transparência" que pleitearia o apagamento da distância entre a experiência dita direta e sua mediação, quando a linguagem desapareceria como construção para surgir confundida com as coisas - em que é o próprio real que parece "falar" (Barthes, 2004) , o ensaio audiovisual atua na ativação da experiência sensível, estética e, evidentemente, mediada, mobilizando as passagens e as indiscernibilidades entre o singular e o coletivo, o privado e o político, a pessoa e o personagem, a memória e a atualidade.

Como veremos, o ensaísmo presente em Santiago e aquele presente em Jogo de cena são de ordens distintas, ainda que ambos sejam caracterizados pela mobilidade e pela explicitação da mediação, pelo rigor da composição e pelo olhar reflexivo, parcial e subjetivo do cineasta - mesmo quando este não se exprime em primeira pessoa. Tal qual um gênero híbrido e moderno, entre a arte e a filosofia, entre a precisão conceitual e a busca por um estilo livre e pessoal, o ensaio se volta contra o imediato para estabelecer mediações, preferindo sempre o parcial, o inconcluso e o fragmentário. Preferindo aquilo que escapa ao pensamento sistemático, de pretensões totalizantes ou dogmático aquilo que escapa, portanto, às rígidas definições conceituais e às deduções definitivas.

Arte do transitório, do contingente e do "despropósito", como sinaliza Adorno (2003:17), o ensaio nos coloca a impossibilidade de exaurirmos uma relação com o objeto, não admitindo conciliação ou consenso nem dissolvendo tensões entre as formas artísticas e nossa experiência social e histórica, entre a construção e a expressão. Nesse embate marcado pela fratura, o gesto ensaístico parte também da admissão de que o sujeito moderno é, desde a origem, atravessado, trabalhado e fracionado pela ficção: sua auto-elaboração é uma autoficção ${ }^{14}$, a qual, no caso do cinema, será mobilizada pela função catalisadora, produtiva e mediadora da câmera.

\footnotetext{
${ }^{14}$ Cunhado por Serge Doubrovski na década de 70 em relação à literatura, a autoficção compreende a subjetividade como produção e se inscreve no coração de um paradoxo: o desejo narcisista de falar de si e
} 
Se o método de abordagem do ensaio é a negação sistemática de todo método, isso não exclui, porém, a possibilidade de um discurso sobre o método, considerando se tratar de uma metodologia lacunar, hesitante, não-sistemática e não-disciplinar. No caso dos dois filmes em questão, e a despeito de suas evidentes diferenças, o método é tomado como um experimento, a partir do princípio de incerteza (Rosset, 1989) que organiza a narrativa, da suspeita que recai sobre a imagem documental e da oscilação entre a crença e a descrença que é tornada condição espectatorial ${ }^{15}$. Só há método, portanto, a partir da dúvida fundadora e "hiperbólica", assim como postulava, ao menos em sua gênese, o método cartesiano, apesar de todas as incompreensões retroativas que o reduziram a um cartesianismo científico mais banal. "Metodicamente sem método", como diria Adorno, o ensaio, o mais inadequado dos gêneros, apenas coordena seus objetos, sem querer subordiná-los a uma lógica prévia e prescrita.

Se o discurso sobre o método só é então possível pela explicitação da mediação - seja uma mediação enunciada por uma voz off 2 no caso de Santiago, ou estruturada pela montagem, no caso de Jogo de cena -, o caráter mediador e perspectivo do ensaio fílmico se evidencia por meio de sua forma. A um só tempo aberta ao mundo, à subjetividade e à heterogeneidade, a forma ensaística também se apresenta fechada, preocupada que é com seu criterioso modo de composição. Tal como um experimento que tem suas regras, que se organiza a partir de um questionamento conceitual, como veremos em Santiago e Jogo de cena, o ensaio também pode ser pensando como um mosaico ou um jogo, no qual importa o modo preciso, embora consciente de sua contingência ${ }^{16}$, por meio do qual suas peças se colocam em movimento e em relação.

\footnotetext{
o reconhecimento da impossibilidade de exprimir uma verdade. Segundo Diana Klinger, "a autoficção é um conceito capaz de dar conta do retorno do autor depois da crítica filosófica da noção de sujeito". In: KLINGER, Diana. Escritas de si, escritas do outro - o retorno do autor e a virada etnográfica. Rio de Janeiro: 7Letras, 2007. p.27. De toda forma, interessa-nos, no âmbito deste trabalho, o que o conceito abriga de inacabado, como algo ainda em vias de se formar, como algo que sempre escapa às rígidas definições conceituais, sobretudo no caso da produção de si em relação à produção de imagens.

15 "Para ser espectador é preciso aceitar crer no que vemos; e para sê-lo ainda mais seria preciso começar a duvidar - sem deixar de crer", preconiza Jean-Louis Comolli (2008:11). Ver também: LINS, C.; MESQUITA, C. "Crer, não crer, crer apesar de tudo - a questão da crença nas imagens na recente produção documental brasileira". Trabalho apresentado ao XVII Encontro Anual da Compós. UNIP, São Paulo, SP, 2008.

${ }^{16}$ Ver XAVIER, Ismail. "El exemplar y lo contingente en el teatro de las evidencias", revista Pensamiento de los Confines v.25, Buenos Aires, 2009.
} 
É por este motivo que o ensaio pressupõe uma instabilidade e uma indeterminação narrativas em que não há unidade nem controle possível, pois a relação entre a palavra, a imagem e o referente deixa de ser imediata, havendo sempre uma hesitação entre a busca de certezas e a impossibilidade de fixá-las, entre a vontade de verdade e todas as impossibilidades da linguagem. Entre os ditos e os não-ditos, o ensaio parece valorizar o que sempre escapa e o que está calado, aquilo que não se é sendo e não se diz dizendo. Tal como está em nossa moderna tradição literária: o narrador de Dom Casmurro, romance de Machado de Assis, ao estabelecer seu projeto memorialístico, diz: "Se só me faltassem os outros, vá; um homem consola-se mais ou menos das pessoas que perde; mas falto eu mesmo, e esta lacuna é tudo" (1997:03).

O ensaísmo documental ou o filme ensaio, atravessado então por uma perspectiva, cética ou trágica, de que seria impossível alcançar o referente, a verdade "por de trás do pano", pois tudo o que há, no âmbito do filme, é a verdade do cinema, a realidade do pôr-em-cena e a autenticidade-em-encenação, vem dialogar com uma tradição em cujo centro se encontrava o problema da verdade e da palavra. Tal como a máscara que oculta ao mesmo tempo em que revela, ou revela justamente porque oculta, as renovadas práticas interativas, reflexivas e ensaísticas, filiadas à tradição do cinéma vérité francês, têm semeado a ultrapassagem, não desprovida de tensão e de problematização, das dicotomias tão caras a nossa tradição de pensamento socráticoplatônico, como os pares essência/aparência, profundidade/superfície, autenticidade/encenação e realidade/ficção ${ }^{17}$.

Antes de prosseguirmos, cabe salientar que, ao afirmar tal ultrapassagem, justaposição ou tensionamento, não se trata de dizer que a verdade e a autenticidade não existam, ou que elas sejam uma farsa, uma dissimulação. Esta perspectiva seria um tanto ingênua, se não fosse também cínica, pois parte do pressuposto - novamente remetido a nossa herança metafísica - de que toda encenação é negativamente falsificante. Ao contrário dessa visada, ainda hoje hegemonicamente compartilhada, deve-se compreender a verdade e a autenticidade, no âmbito da linguagem audiovisual, como um efeito de uma construção que se dá em relação e em reação à câmera. Desse

\footnotetext{
${ }^{17}$ Contra os discursos desconstrutivistas e cognitivistas que pregariam a indistinção entre documentário e ficção, reduzindo toda a diferença a protocolos formais e sociais de produção e recepção das imagens, César Guimarães e Rubens Caixeta postulam uma diferenciação (ainda que provisória) entre documentário e ficção. Tal distinção se basearia em uma aproximação fenomenológica, dedicada a compreender a inscrição dos vestígios do real e dos sujeitos (a relação entre quem filma e quem é filmado) no mundo da vida e no mundo da vida filmada. Ver: GUIMARÃES, César; CAIXETA, Rubens. "Pela distinção entre ficção e documentário (provisoriamente)". In: COMOLLI, Jean-Louis. Ver e poder: a inocência perdida - cinema, televisão, ficção, documentário. Belo Horizonte: UFMG, 2008. p.36
} 
modo, a câmera deixa de ser somente um instrumento de captação ou registro para tornar-se, simultaneamente, um instrumento de catalisação e de produção das verdades dos personagens. Como já dissera o "mestre dos mestres" Jean Rouch, para quem a ficção era o único caminho para se penetrar a realidade, "a câmera não deve ser um obstáculo para a expressão dos personagens, mas uma testemunha indispensável que motivará sua expressão" (Rouch apud Bragança, 2004) ${ }^{18}$.

Aí está, portanto, a função produtiva da interação reflexiva proposta por João Salles e Eduardo Coutinho, intervenção como condição de possibilidade do pôr em cena, pelo gesto e pela palavra, daquilo que estaria latente, oculto, esquecido ou a ser ainda inventado. Por caminhos ensaísticos distintos - o "teatro da entrevista" em Jogo de cena ou o "discurso autobiográfico mediado pela entrevista" em Santiago -, Coutinho e Salles não só criam o filme e seus personagens como criam uma dimensão de "si mesmos" (e "deles mesmos") que não poderia existir sem o filme, dimensão a um só tempo real e imaginária, autêntica e encenada, presente e passada. Dimensão que, para além do "despropósito" e das "inutilezas" do gesto ensaístico, torna cada um dos filmes necessário e intransferível, na medida em que as próprias obras operam como um singular modo de subjetivação. Como veremos, os recursos à "expressão de si" por meio de práticas e gestos confessionais, tradicionalmente empregados para a inscrição dos sujeitos em um regime discursivo verídico ${ }^{19}$, serão torcidos e revirados em Santiago e Jogo de cena.

\footnotetext{
${ }^{18}$ Decerto, trata-se aqui, diferentemente do ideal de "testemunha ocular" do cinema-direto norteamericano, movimento, aliás, mais complexo do que as leituras posteriores nos fazem acreditar, de outro tipo de testemunha, espécie de "estimulante psicanalítico", segundo Rouch, com o qual é possível interagir. Não deixa de ser digno de nota o modo pelo qual a relação entre o potencial produtivo da câmera e a mobilização da capacidade expressiva dos sujeitos filmados foi capitalizada e instrumentalizada pelos espetáculos televisivos (tais como reality shows e derivados), que levaram ao limite a experiência moderna do cinéma vérité francês. A esse respeito ver: FELDMAN, Ilana. "Reality show: um dispositivo biopolítico". In: Estéticas da biopolítica: audiovisual, política e novas tecnologias. Revista Cinética / Programa Cultura e Pensamento (MinC), 2008.

${ }^{19}$ Esse regime discursivo de pretensões verídicas, vale ressaltar, não se restringe aos saberes, práticas e poderes desenvolvidos no âmbito das sociedades disciplinares, como tão bem cartografou Michel Foucault, mas alastra-se hoje (talvez em função da crise de legitimação por que têm passado as instituições disciplinares) pelos media, dos discursos jornalísticos a séries de TV do tipo "Engana-me se puder" (Fox), sobre uma equipe de peritos especializados em decodificar manifestações "da verdade ou da mentira" nas expressões corporais de suas cobaias. Declaradamente inspirada nessa série, a Folha de São Paulo contratou um psicólogo americano (fundador de uma "empresa de serviços para análises de comportamento não-verbal") para analisar as expressões faciais dos candidatos à presidência da República (coluna "Tá na cara", FSP, 29/08/10). Em várias de suas edições, o reality Big Brother Brasil (Globo) também empregou no "confessionário" do programa um sistema eletrônico (ou polígrafo) chamado "detector de mentira" ou "máquina da verdade", para acusar inverdades "por meio da análise da voz, temperatura corporal, pulsação, íris e até da respiração" (FSP, de 14/01/2008). Disponível em: http://www1.folha.uol.com.br/folha/ilustrada/ult90u363102.shtml
} 
Entre "a vontade de saber" e a recusa aos sentidos estabilizados, entre a vontade de controle e as contingências do acaso - figura, aliás, cada vez mais desejada, investida e capitalizada pelo documentário brasileiro contemporâneo -, Santiago e Jogo de cena demonstram a excessiva autoconsciência de que a posição de controle, tão cara ao espectador de televisão (que sabe, julga e decide), é insustentável, tanto no cinema quanto na vida, como enfatiza o crítico Jean-Louis Comolli (2008). Nesse sentido, enquanto a experiência de Jogo de cena busca a irrupção ou a encenação daquilo que chamamos de acaso, em Santiago acompanhamos a tentativa, por vezes desesperada, de sufocá-lo, tentativa que constituirá o cerne da reflexão do filme sobre si próprio. O "acaso", no entanto, na qualidade de efeito construído pelas experimentações modernas e convertido em arena de disputa contemporânea (pois implica, como moeda de troca, certo coeficiente de "autenticidade" das obras), seria inominável, irrupção do impensado: aquilo que tornaria as imagens sempre instáveis, fugidias e insuficientes para nomear o real.

No entanto, se as imagens, assim como as palavras, são sempre precárias, "é justamente por todas as precariedades, a partir de todas as lacunas, apesar de todos os riscos, que é possível trabalhar com elas" (Lins; Mesquita, 2008:10). Ao privilegiar, portanto, determinadas aproximações e recortes em detrimento de tantos outros, que, por força do caráter sintético de um texto e da complexidade dos objetos, ficam obscurecidos, opta-se por uma entrada também parcial, contingente e lacunar nos universos fílmicos, sem pretender assim esgotá-los ou subjugá-los a conceitos e teorias prévias. Resguardar tanto o inaudito quanto a materialidade das obras e suas relações com a experiência social e histórica, sem reduzi-las à pura empiria descritiva, faz-se o desafio de toda prática crítica e analítica.

Assim, após a negatividade fundamental de que parte Dom Casmurro (e que, como veremos, é compartilhada pelas narradoras de Coutinho e por Santiago, o personagem), em que o fundamento do sujeito não se encontra no cogito, mas justamente naquilo que lhe escapa ou que lhe falta, há que se crer que, assim como acontece com as imagens, aquilo que se oculta de um texto - seu fora de quadro, seu negativo - é tão revelador quanto aquilo que se diz.

\section{Por dentro dos filmes e de suas metodologias:}




\section{profundamente as superfícies}

Em Santiago, obra do diretor João Moreira Salles dedicada ao mordomo Santiago Badariotti Merlo (1912-1994) que servira sua família por pelo menos três décadas, trata-se do filme dentro do filme, isto é, de uma reflexão do diretor sobre o material bruto que, captado treze anos antes, em 1992, ficara intocado, como um desejo extraviado e um projeto fracassado. O método, explicitamente auto-reflexivo, e as opções estéticas e estilísticas do cineasta, com seus recortes e perspectivas, tornam-se assim o próprio tema: tanto na camada sonora, por meio da narração em voz off de uma primeira pessoa "terceirizada" 20 , a qual suspeita dos procedimentos empregados no filme fracassado (o filme que fora feito treze anos antes), como pelo manejo e incorporação das imagens desse antigo filme que agora, no presente da narração, dá forma a um outro.

Respondendo a suas inquietações pessoais e a uma defesa por um "cinema inútil" ${ }^{21}$, conforme expressão do diretor, um cinema comprometido em primeiro lugar com a investigação da própria linguagem (e não apenas da realidade), João Moreira Salles retoma em 2005 a montagem do material bruto captado em 1992, voltando-se, pela primeira vez em sua trajetória, para o seu mundo particular. Assim, Se em Nelson Freire (2002) e Entreatos (2004) Salles acompanha, por um determinado período, a rotina de personagens tão singulares quanto ilustres, como o pianista Nelson Freire ou o então candidato à presidência da República, Luis Inácio Lula da Silva, é em Santiago que Salles, ao encontrar seu personagem definitivo, reencontra um novo caminho para seu documentário.

Pavimentado por diversas camadas de matéria, de memória e de sentido, Santiago contempla distintas linhas narrativas que se justapõem: filme sobre o processo equivocado de um primeiro documentário abortado; filme sobre a memória prodigiosa do ex-mordomo Santiago; filme sobre a memória da família Moreira Salles, acessada

\footnotetext{
${ }^{20}$ Sabe-se que a voz do narrador que narra em primeira pessoa do singular pertence ao irmão de João, Fernando Moreira Salles. Essa informação, para quem a ela tem acesso, confere ao filme mais uma camada de ambigüidade.

${ }^{21}$ Segundo Salles, o documentário não teria a obrigação de consertar o mundo, mas de transformar o próprio documentário, quando a atenção migra do tema para a maneira de narrar e o olhar que se voltava para fora, interessado apenas no "outro", de outra classe social, volta-se para dentro, interessado em temas próximos à vida dos diretores. Ver: SALLES, João Moreira. "O cinema inútil”. O Estado de S.Paulo, Caderno 2, 24 de julho de 2005.
} 
por meio do encontro, ou da tensão, entre a memória de Santiago e a memória de João Salles; filme sobre a suspeita de um documentarista, que desconfia, não desprovido de certezas, de seu material filmado, de si mesmo e da própria vida; e, ainda, filme cujo tema último é o tempo e o desaparecimento, mas cuja forma crê na imagem como antídoto para o esquecimento.

Se Santiago apresenta tantas camadas, tanto do ponto de vista da composição dos planos como da estrutura urdida pela montagem, ele o faz incorporando seus restos, suas sobras, suas bordas, aquilo que no filme original estaria de fora, aquilo que ele não mais é. É o que deixou de ser - ou só é porque deixou de ser, ambigüamente ainda sendo. Gestos de Santiago, expressões faciais, aflições, silêncios, hesitações. Falas do documentarista, recusas, pedidos de repetição, afeto dominador, impaciência e prepotência. Repetições para a câmera, variações de ângulo de um mesmo plano, rastros de imagem e de vida, anteriores e posteriores aos comandos de "ação!" e de "corta!", e, até, a presença de uma seqüência integral da primeira montagem de 1992, ainda com o time code na tela a nos lembrar que o tempo, além de uma experiência que dura, é uma medida com a qual não se negocia.

Em Jogo de cena, o método até então empregado por Eduardo Coutinho, assentado sobre a prática da entrevista (que o diretor prefere chamar de conversa, encontro, relação) e pautado pela valorização da capacidade narrativa e expressiva de seus personagens (que interagem com Cotinho e reagem a sua câmera no espaço da cena documental), torna-se o próprio tema, sendo radicalizado. Aqui, temos mulheres que, atendendo a um anúncio de jornal, narram suas histórias de vida sobre um palco de teatro vazio, histórias que serão posteriormente encenadas por atrizes, conhecidas ou desconhecidas do grande público, sobre esse mesmo palco. Em Jogo de cena, a explicitação do método não passa por sua tematização verbal, mas pela forma como a estrutura fílmica se organiza, prescindindo de um discurso explicativo transcendente em relação a essa estrutura.

O método ou o dispositivo, isto é, o conjunto protocolos formais e espaciais (que Coutinho também costuma definir como "prisão") que organizam, controlam e limitam a cena, abrindo-a para situações e conexões imprevistas, nos é apresentado a partir do seguinte encadeamento: após o primeiro plano do filme, em que se vê o anúncio de jornal convocando mulheres a narrarem suas histórias pessoais, sucedido pela seqüência em que temos a primeira narradora sentada sobre o palco do teatro, somos introduzidos à segunda seqüência do filme, a partir da qual ele efetivamente "começa". Esta segunda 
seqüência nos apresenta o depoimento da personagem ${ }^{22}$ Gisele quando, em meio a seu desenrolar, uma atriz conhecida, no caso Andréa Beltrão, aparece pela primeira vez repetindo a última frase dita por Gisele: "então eu saí do foco do casamento". A partir daí, o pensamento "do" filme "sobre" si próprio, por meio da rigorosa "economia narrativa" (Lins, 2004) de Coutinho, no caso um único cenário - o teatro - e pouquíssimos movimentos de câmera visando sempre o privilégio do rosto $^{23}$ (este templo da verdade e do engano), estará em relação de imanência com a estrutura disposta pela montagem.
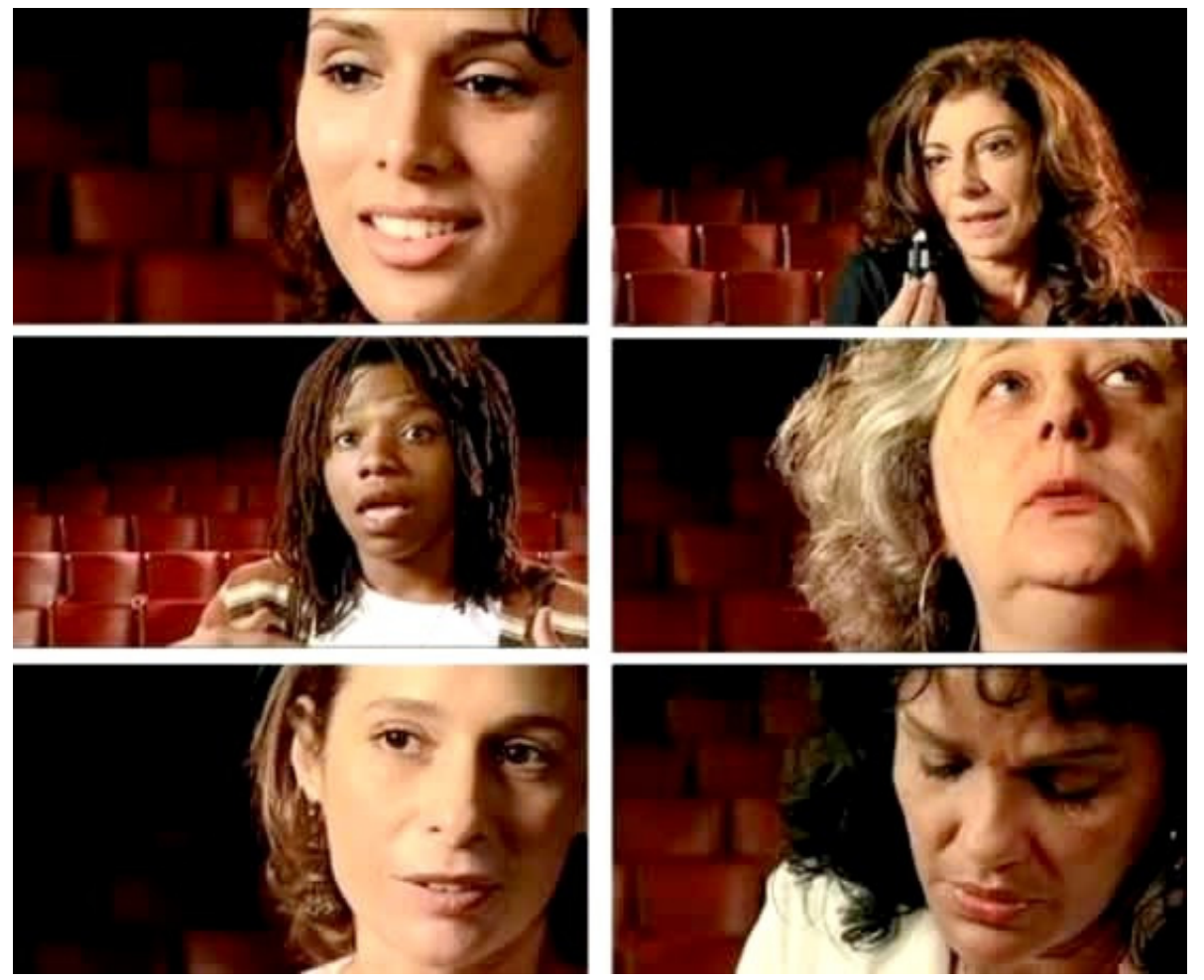

\footnotetext{
${ }^{22}$ Entendemos personagem em sua acepção de figura pública, que, na situação da filmagem, manifesta-se em relação e em reação à câmera ou já pressupondo um efeito-câmera.

${ }^{23} \mathrm{Em}$ sintonia com o gesto de filmar a fala, os filmes de Coutinho concedem uma inquietante potência ao rosto (pelo que há nele de ambíguo e irredutível) e à fisionomia (pela cristalização de uma rede de relações sociais que ela expressa). Para o filósofo italiano Giorgio Agamben (apud Guimarães, 2010:187), o rosto é o "estado da exposição irremediável do homem e, ao mesmo tempo, sua dissimulação justamente nessa abertura". Segundo Guimarães, sem esconder um segredo nem ocultar a verdade, e longe de se reduzir a um simulacro, o rosto está mais próximo da simultaneidade das várias faces que o constituem, sem que nenhuma seja mais verdadeira do que as outras. Ver GUIMARÃES, César. "Comum, ordinário, popular: figuras da alteridade no documentário brasileiro contemporâneo". In: MIGLIORIN, Cezar (org.). Ensaios no Real. Rio de Janeiro: Azougue, 2010. Sobre a questão da fisionomia, ver também XAVIER, Ismail. "O mundo tem as caras que pode ter". In: CEVASCO, Maria Elisa; OHATA, Milton (Orgs.) Um crítico na periferia do capitalismo: reflexões sobre a obra de Roberto Schwarz. São Paulo: Companhia das Letras, 2007.
} 
Santiago é narrativamente mais organizado e os sentidos por ele produzidos são precisos, enquanto Jogo de cena é estruturalmente mais esquivo e os sentidos por ele produzidos são erráticos, em função de uma montagem, que, por meio de seus cortes, produz uma complexa dinâmica de repetições, acúmulos, alterações e antecipações, visando variadas formas de colocar as falas e as fisionomias das personagens em relação. Em Jogo de cena, as atrizes muito conhecidas funcionam como uma espécie paradoxal de âncora fincada na realidade, âncora que garantiria a (suposta) certeza da encenação das atrizes que reconhecemos e sabemos que interpretam, como Andréa Beltrão, Fernanda Torres e Marília Pêra. Mas, e se houver atrizes cujos rostos nos sejam desconhecidos? E as atrizes estariam interpretando o quê? Outra pessoa ou as suas experiências pessoais ao interpretar outra pessoa, portanto a "si mesmas"? Assim, quando não-atrizes interpretam o que vivem e atrizes profissionais (conhecidas ou desconhecidas) vivem o que interpretam, cria-se uma inequívoca zona de indeterminação, ambigüidade e indistinção entre experiência e representação, vida e cena.

Tal desestabilização se faz radicalmente presente na seqüência em que a personagem Aletha e a atriz Fernanda Torres são alternadas pela montagem, de modo a se produzir um incendiário curto-circuito entre as falas de uma e outra (que seria da ordem da ambivalência) e dentre as falas "de" Fernanda (que seria da ordem da ambigüidade). Desestabilizada desde o princípio por Coutinho, que interrompe o pacto de encenação em seu primeiro instante ("Você fez igualzinho a ela"), Fernanda Torres, já um pouco atônita, tem sua fala cortada por uma frase de Aletha ("Contar não é um problema, meu problema é seguir uma corrente"), fala que passa novamente à Fernanda, em um longo plano-sequiência em que a atriz vai ficando cada vez mais confusa: perde o fio da meada, repete algumas frases, tenta rememorar, olha para baixo, hesita, retoma de onde havia parado, balbucia comentários, até que, até que não sabemos mais "quem" fala...

....eu não tomava pílula, eu falava ah, não, não vou tomar pílula não, todo dia a mesma hora, vou tomar é uma injeção, que me parecia algo mais potente... Daí que não funcionou, né?... Que eu tô com a minha filha aí... Mas foi super ignorância mesmo... Porque a injeção tinha que esperar um mês para ter validade... Aí fui eu, muito apressada... Aí que é a merda.... Que coisa idiota, né?... Que coisa idiota... Se eu fiquei com raiva? Que loucura, gente, que loucura, nossa, que dificuldade que eu to passando... Que loucura... Que ódio... [e encarando Coutinho fixamente] que loucura, Coutinho... 


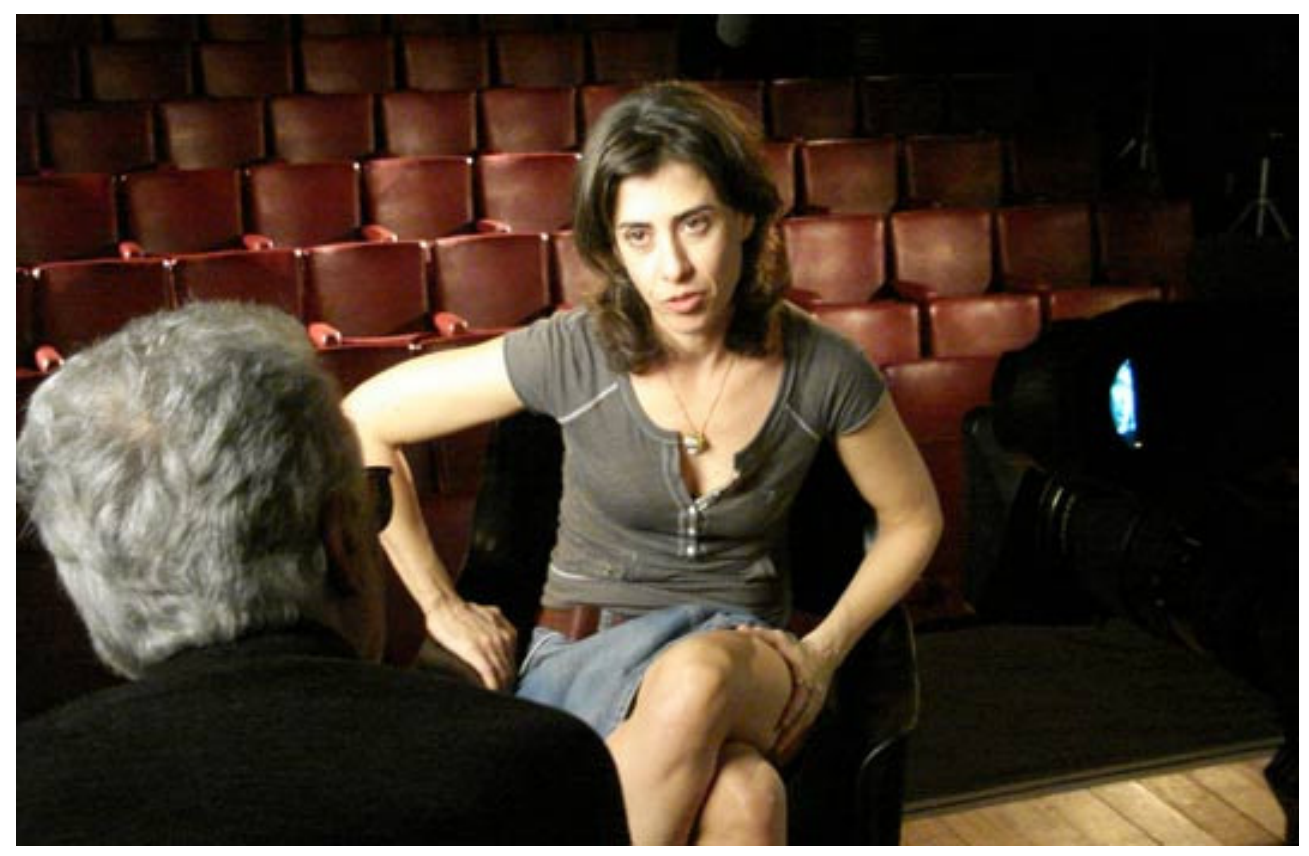

Desestabilizando assim a relação entre fala, expressão da subjetividade e relato testemunhal de histórias de uma vida, seria possível afirmar, como acredita o crítico Jean-Claude Bernardet (2008), que Jogo de cena coloca em dúvida a relação de propriedade entre o corpo falante e a fala pessoal, supostamente intransferível, terminando com isso por desestabilizar a noção de sujeito. Como já dissera Gilles Deleuze, em uma entrevista à Cahiers du Cinéma em 1976 a respeito de um programa de televisão de Jean-Luc Godard, "falar, mesmo quando se fala de si, é sempre tomar o lugar de alguém" (2000:56). Assim, além de uma "loucura", como diz Fernanda Torres (ou Aletha?) a Coutinho, Jogo de cena seria, portanto, de acordo com Bernardet, de uma "trágica radicalidade", já que, ao dissolver o sujeito entrevistado, acabaria por dissolver também o sujeito entrevistador ${ }^{24}$ - inviabilizando com isso, segundo o crítico, a prática da entrevista, marca da filmografia de Coutinho desde Santo forte (1997).

No caso de Santiago, o ensaísmo desenvolve-se no sentido do debruçar-se sobre si, sobre suas escolhas, mas essa construção metalingüística é articulada por uma narração em off organizadora, serena e carregada de certezas sobre aquilo que narra (e suspeita). Construída simultaneamente ao processo de edição, essa narração na primeira pessoa do singular permite que o cineasta possa interrogar a natureza do documentário

\footnotetext{
24 "Esse cineasta interlocutor sentado atrás da câmera não só não faz mais sentido, como não é mais possível após Jogo de cena, que dissolveu o sujeito entrevistado e, por conseqüência, o sujeito entrevistador" (Bernardet, 2008).
} 
enquanto reflete sobre o tempo que separa a filmagem da montagem e sobre a distância que se instala - não só no tempo, mas no próprio espaço da cena - entre diretor e personagem. Assim, em Santiago não há propriamente o jogo de revelação e ocultamento com o espectador, marca de Jogo de cena, mas há a problematização, por meio da voz do narrador, das regras e das condutas - estéticas e sócias - que compõem e constroem a cena.

Construído como um filme que se organiza a partir do questionamento de seu próprio método, Santiago termina por ser um filme sobre a mediação - igualmente estética e social -, em que o diálogo com o cinema se faz explícito por meio da utilização de trechos de filmes de Vincent Minellli e Yasujiru Ozu, de imagens domésticas em Super-8 e de fotografias de sua família. Sem dúvida, todos esses materiais são marcados, em sua heterogeneidade, por uma noção de recato e decoro materializada pela recusa aos planos próximos por demais invasivos. Do mesmo modo, as imagens produzidas para Santiago, assentadas na seletividade do olhar e na opção pelos planos fixos, abertos e em profundidade de campo, em que há sempre algum anteparo entre a câmera e o corpo do ex-mordomo (como cortinas, sombras, portas, maçanetas e objetos diversos), recusam - ao contrário de Jogo de cena - o close up do rosto de seu protagonista, exceção feita a um único plano próximo de uma coreografia executada pelas mãos de Santiago.

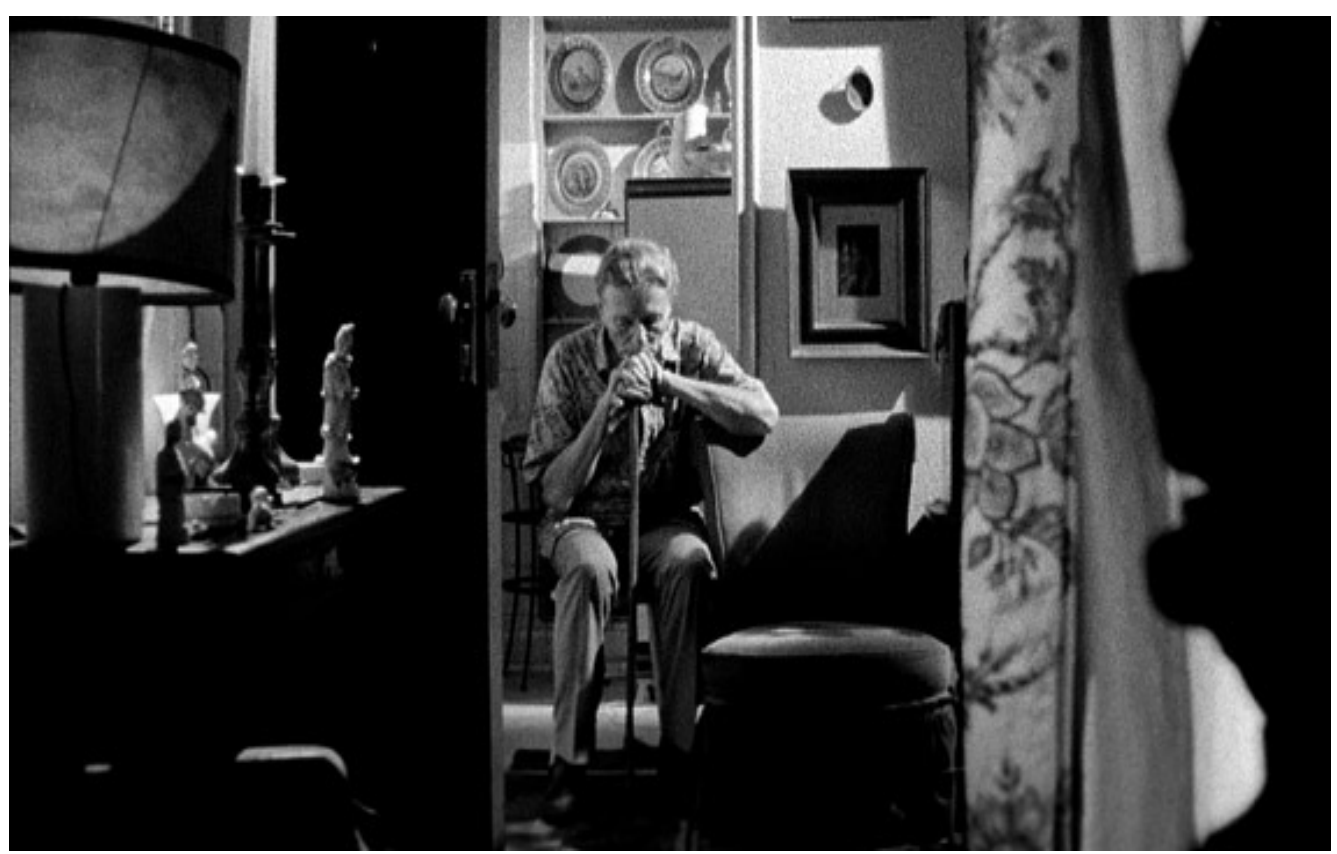




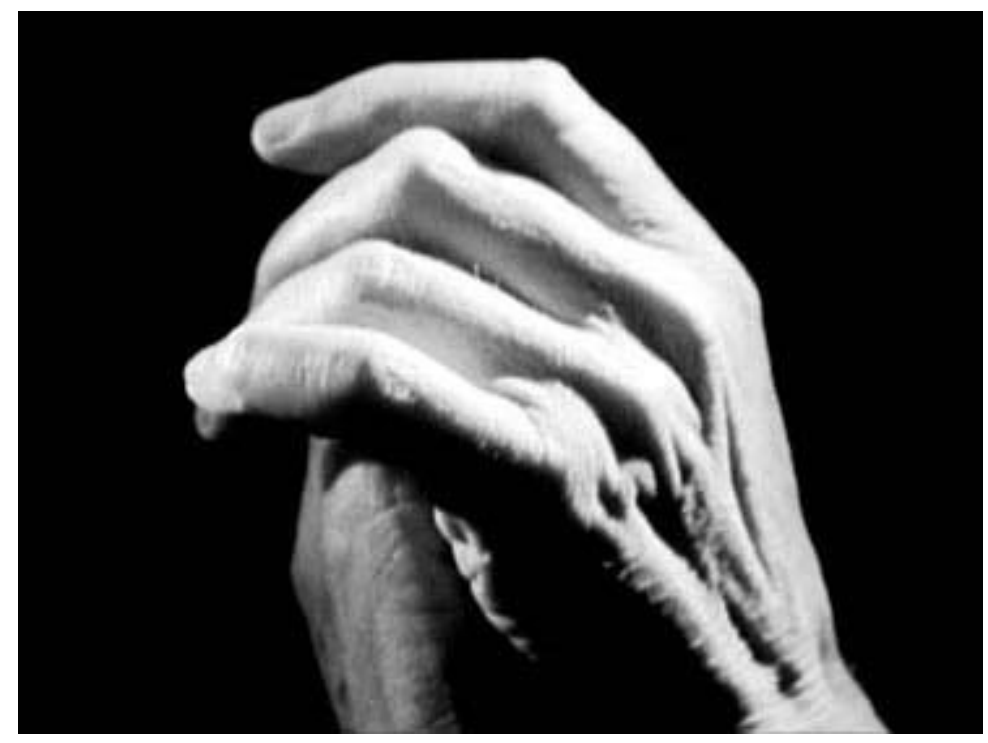

Não por acaso, e aí reside uma das maiores grandezas de Santiago, esse rigoroso programa estético formaliza os protocolos sociais mediadores da relação entre Salles e Santiago, como a distância que se instala entre documentarista e personagem, ou patrão e empregado, na reprodução da assumida relação de classe. Contudo, nessa reflexão sobre o material bruto, Santiago, o filme, não chega a interrogar, de fato, o mundo de que trata, ele apenas lamenta o seu desaparecimento, como se o trabalho sobre si, fundamentalmente um trabalho de luto (lembremos do predomínio das telas pretas a perpassar todo o filme), fosse também ele dolorosamente interrompido pelos comandos de "corta!" e de "não!".

Já no caso de Jogo de cena, filme que radicaliza ${ }^{25}$ o método de Eduardo Coutinho, depurando seus procedimentos e nos impelindo a repensar, retrospectivamente, toda a sua obra pregressa, o ensaísmo se faz presente, sobretudo, na forma como a estrutura se organiza. Uma estrutura lacunar, errante, que, ao desdobrar e duplicar as falas femininas, não aponta para nenhum sentido fora do filme, isto é, para nenhuma verdade que lhe seja exterior, mas para a verdade do cinema e $d a$ cena, ultrapassando as usuais dicotomias entre pessoa e personagem, singular e coletivo, autenticidade e encenação, memória e presentificação. Se o método de Coutinho tem

\footnotetext{
${ }^{25}$ Em seu filme Moscou (2009), imediatamente posterior a Jogo de cena, sobre o acompanhamento dos ensaios da peça "As três irmãs", de Tchekhov, pelo grupo teatral Galpão, Eduardo Coutinho aprofunda a investigação da linguagem. Subvertendo seus métodos e procedimentos usuais (o emprego da entrevista e a presença de homens e mulheres "comuns"), Coutinho rompe qualquer ligação com o referente, a ponto de a "documentação" do processo de ensaio "real" ser completamente enredada pelo texto ficcional. Ver FELDMAN, Ilana. "Moscou: do inacabamento ao filme que não acabou". Revista Cinética, abr. de 2009. Disponível em: http://www.revistacinetica.com.br/moscouilana
} 
sido pautado pela mobilização da capacidade de auto-mise-en-scène $e^{26}$ ou autoficção de seus personagens, em Jogo de cena, a interrogação do filme sobre si (sobre a cena e em cena) é radicalizada, gesto que remete, como aponta Ismail Xavier (2010:67), ao "Paradoxo do comediante" de Diderot, como já havia deixado claro a fala da personagem Alessandra, de Edifício Master (Eduardo Coutinho, 2003): "Sou uma mentirosa verdadeira".

A Coutinho, portanto, interessa não a simples evocação de experiências pessoais, mas o modo como essas experiências são evocadas. Interessa a expressividade, não o conteúdo da expressão. "Eu não separo ela do que ela diz", nos fala a atriz e personagem Fernanda Torres, comentando sua fracassada tentativa de interpretar a personagem, e aparentemente não-atriz, Aletha, cujo próprio nome remete à aletheia grega, "a verdade no sentido da revelação" - como explica a personagem sobre o significado de seu nome. Etimologicamente formada por a+lethé, isto é, a negação (o prefixo "a") daquilo que estaria oculto, obscurecido, silenciado ou esquecido ("lethé"), a aletheia grega estaria etimologicamente relacionada à luz, à palavra e, sobretudo, à memória (Detiènne, 1993:21). Desse modo, nessa espécie particular de estética performativa da existência, em que a palavra rememorada, como ato de fala, instaura seu próprio regime de verdade, o cinema de Coutinho, como sintetiza Ismail Xavier, "tem como horizonte a apresentação de um sujeito como foco de um estilo" (2010:78), valendo aí o princípio de que as pessoas são "interessantes", "carismáticas" ou "extraordinárias" (termos, embora muito rentabilizados pelos espetáculos televisivos e pelo mundo corporativo, bastante empregados pelo próprio Coutinho) quando "recuperam na conversa um sentido de autoconstrução que tem sua dimensão estética" (Ibid).

Se a metodologia é, portanto, parte dos processos de ambos os filmes, em Santiago assistimos ao resultado de um processo, enquanto em Jogo de cena acompanhamos o processo de um resultado. De fato, do mesmo modo que em ambos os filmes suas construções formais se dão em uma relação de tensão entre o ilusionismo e a reflexividade, o controle e o acaso, o rigor do dispositivo e a liberdade do ensaísmo, no que diz respeito às suas temáticas, ambas giram em torno do eixo perda e superação da perda. Seja mais explicitamente a melancólica e dilacerante perda de um tempo, de

\footnotetext{
${ }^{26}$ A expressão auto-mise-en-scène, recorrentemente empregada por Jean-Louis Comolli (2008) teria sido primeiramente postulada por Claudine de France, em Cinema e Antropologia (Campinas: Ed. UNICAMP, 1998, trad. Marcius Freire).
} 
pessoas e de uma promessa modernista de país que já se foram, como em Santiago, seja a trágica perda ou o abandono de filhos, pais e maridos, como em Jogo de cena. Da tragédia Medéia, de Eurípedes, à animação Procurando Nemo, passando por sonhos revelatórios, menções às mitológicas HQ de Hal Foster e desejos não realizados de ser paquita no Show da Xuxa, os depoimentos das mulheres de Jogo de cena flertam com as lágrimas do melodrama, porém escapando de suas armadilhas, com a mesma intensidade com que o fazem com o fatalismo trágico ${ }^{27}$.

Mas, nesse caso, por que mesmo um filme apenas com mulheres? Não só porque elas são "o outro", o que Coutinho não é, e porque "todo grande ator é mulher", como costuma justificar o diretor. Ambíguas e "superficiais por profundidade" (Nietzsche apud Ferraz, 2005), aproximar-se das mulheres, historicamente associadas às forças da sedução e da pura aparência cosmética (no sentido da kosmetike grega, que incluía as artes do tingimento, da pintura e da maquiagem), significaria, no esteio sugerido por Nietzsche, inviabilizar as camisas-de-força identitárias e as dicotomias tão caras à nossa tradição de pensamento. Ambigüidade e esquiva que colocariam por terra certa tendência a se de perceber Jogo de cena como um sumário jogo de caça aos "sete erros", de identificação e dicotomização do verdadeiro e do falso. Antes, as mulheres de Jogo de cena, assim como aquelas entidades da Grécia arcaica conhecidas por sereias ${ }^{28}$, talvez sejam elas mesmas verdadeiras $e$ falsas.

Nesse regime de verdade instaurado pelo filme em que as aparências não podem ser desqualificadas como ilusórias, falsas ou inexistentes, poderíamos convocar a frase do psicanalista Serge André (1995), a partir do legado freudiano: ser mulher, queira-se ou não, é pretender, simular ou parecer ser mulher ${ }^{29}$. Modernamente e psicanaliticamente vinculadas ao signo da falta, as mulheres, segundo a psicanálise e de acordo com a admissão de que nada existiria por trás do muro da linguagem, seriam impelidas, para não sucumbirem (tal como ocorrera com a célebre personagem de

\footnotetext{
${ }^{27}$ É curioso notar que já no primeiro depoimento de Jogo de cena, o da personagem que fora "salva" pelo teatro, há uma menção à tragédia Medéia, de Eurípedes, com a reencenação pela personagem do momento em que Medéia é levada a matar os filhos. Sobre a relação entre a cena trágica, o luto e a dor das mães (cujo excesso é sempre ameaçador), ver o interessante trabalho sobre as mães enlutadas, de Atenas a Roma, de Shakespeare a Freud, de LORAUX, Nicole. Les mères en deuil. Paris: Seuil, 1990.

${ }^{28}$ Marcel Detiènne, em Os mestres da verdade na Grécia arcaica (1993), analisa a lógica da ambigüidade própria à palavra mítico-religiosa da Grécia arcaica (lógica que permite às sereias serem, a um só tempo, verdadeiras e falsas) e a passagem à lógica da contradição (que condenará as sereias à ilusão e à falsidade), inerente ao regime da palavra laicizada, base da Grécia clássica. Ver também o ensaio "O simulacro e suas implicações em Deleuze, Nietzsche e Kafka", em Nove variações sobre temas nietzschianos, de M. Cristina F. Ferraz (2002).

${ }^{29}$ No original: "Être femme, c'est, qu'on le veuille ou non, faire semblant d'être femme". In: ANDRÉ, Serge. "De la mascarade à la poesie". In: Que veut une femme? Paris: Seuil, 1995. p.279
} 
Flaubert, Madame Bovary $^{30}$ ), a inventar novas perspectivas narrativas, a criar uma estilística ou uma escritura no âmago do próprio presente, abandonando uma vida organizada pela promessa e pela esperança. Abandonando uma vida de quem, tal como a personagem G.H, de Clarice Lispector, prefere continuar pedindo, sem ter a coragem de já ter ${ }^{31}$. Talvez seja desse abandono e dessa necessidade de atualidade de que falam as personagens de Coutinho.

Em Jogo de cena, assim como em Santiago, a atualidade advém de uma radical impossibilidade: impossibilidade de dizer, de nomear, de se adequar. Se Santiago não trata apenas da relação entre o mordomo e o filho do patrão, mas de uma espécie de vazio constitutivo, que se exprime pela impossibilidade de o narrador realmente se expor, em Jogo de cena nenhuma palavra nem lágrima podem dar conta do que aquelas mulheres têm a dizer. O que nos leva a intuir que, em algum lugar dessa opacidade constitutiva, da qual o "vazio" é um de seus nomes, está a dor e a plenitude de um sentido que só pode ser compreendido pela ausência. Distantes, portanto, de qualquer relação de transparência entre sujeito e linguagem, tanto as mulheres de Jogo de cena quanto Santiago, o personagem, estariam mais próximos da opacidade postulada pela personagem "filósofa" GH, quando ela belamente formula: "Eu tenho à medida que designo - e este é o esplendor de se ter uma linguagem. Mas tenho muito mais à medida que não consigo designar" (1998:176).

Sejam as proliferações discursivas em Jogo de cena (por meio da escuta "psicanalítica" de Coutinho e das variadas formas de duplicação de alguns depoimentos), sejam as repetições repressivas em Santiago (em função do autoritarismo de seu realizador), essas diversas formas de fazer falar e fazer calar não estariam, portanto, a serviço de nenhuma capacidade revelatória da linguagem. Capacidade essa comumente atribuída ao cinema de Eduardo Coutinho, ao menos até Jogo de cena, como se linguagem pudesse "repor o sujeito"32 da enunciação.

\footnotetext{
${ }^{30}$ Segundo Maria Rita Kehl, em Deslocamentos de feminino (2008), a personagem Madame Bovary, centro de seu estudo, teria posto fim a sua vida porque não conseguira escrever, não conseguira tornar-se autora - de textos, cartas, poemas - e, afinal, da própria vida. No entanto, se Emma Bovary sucumbiu, algumas personagens de nossa moderna literatura conseguiram criar outras perspectivas narrativas, tal como a pintora do romance Água Viva, de Clarice Lispector, para quem, aliás, ao fundo de cada cor nada haveria por trás: "Não quero ter a terrível limitação de quem vive apenas do que é passível de fazer sentido. Eu não: quero é uma verdade inventada" (1976:23).

31 "Prescindir da esperança significa que eu tenho que passar a viver, e não apenas a me prometer a vida (...) [Mas] eu preferia continuar pedindo, sem a coragem de já ter" (1998:148).

${ }^{32}$ No paradigmático texto "Indagações em torno de Eduardo Coutinho e seu diálogo com a tradição moderna”, Ismail Xavier escreve a certa altura “(...) o diálogo capaz de ensejar a reposição do sujeito
} 
Nesse sentido, é possível que a não adesão, por parte de alguns críticos, a Moscou (2009), obra de Eduardo Coutinho imediatamente posterior a Jogo de cena, advenha desse impasse da linguagem que o filme coloca. Para além de sua estrutura dispersiva e centrífuga (e não mais concêntrica e centrípeta, como em seu cinema pautado pela entrevista) e do fato de que Coutinho, pela primeira vez, se retirou de cena, deixando em seu lugar uma espécie de ausência, em Moscou a linguagem deixaria de "restituir a singularidade" dos sujeitos falantes, nos termos em que a crítica valorizou até aqui o trabalho de Coutinho, para alcançar, por meio da ficção (quando o processo documental é completamente enredado pelo texto ficcional), sua autonomia em relação aos tradicionais referentes que sempre pautaram o cinema de Coutinho até então: a vida própria do ser comum. Autonomia essa que, por meio de uma radical partilha biográfica posta em cena pelo filme (a que também se poderia chamar de impropriedade biográfica), dissolveria a idéia de enunciação individual e explicitaria o caráter coletivo de toda enunciação.

Entretanto, de acordo Gilles Deleuze e Felix Guattari, não haveria enunciação individual nem mesmo sujeito da enunciação (1995:17), havendo apenas individuação do enunciado e subjetivação da enunciação "na medida em que o agenciamento coletivo impessoal o exija e o determine" (1995:18). Se a formulação da dupla é radical, e um tanto problemática, pois parece dissolver a contingencial irredutibilidade de uma vida, por outro lado, afirmar que todo enunciado é coletivo equivaleria a dizer que não somos proprietários daquilo que dizemos, já que muitas vozes indiscerníveis falam pela nossa voz, já que tantos gestos alheios se repetem em nós - como também postula Mikhail Bakhtin e sua teoria do dialogismo ${ }^{33}$. É a partir de tal ponto de partida que a fabulação, ou a função fabuladora, tão cara às narradoras de Coutinho e a Santiago, o personagem, pode ser compreendida. Nem mito impessoal, nem ficção pessoal, "a fabulação é uma palavra em ato, um ato de fala pelo qual a personagem nunca para de atravessar a fronteira que separa seu assunto privado da política, e produz, ela própria, enunciados coletivos" (Deleuze, 2005:264).

[grifo nosso] deve começar pelo convite à fala, por mais que aí se reitere o impulso das pessoas a se projetar no que julgam ser as expectativas do olhar público a elas dirigido" (2010:77).

${ }^{33}$ Como teria dito Bakhtin, citado por Todorov: "No fundo do homem não está o 'id', mas o outro (...). A consciência é muito mais assustadora do que todos os complexos inconscientes" (Todorov, 1981:65 apud Dahlet, 2005:60). E ainda: "Não podemos perceber e estudar o sujeito enquanto tal, como se fosse uma coisa, já que ele não pode permanecer sujeito não tendo voz; por conseguinte, seu conhecimento só pode ser dialógico" (Todorov, 1981:281 apud Dahlet, 2005:58). 
Tratando da própria narrativa e da narração fabuladora, da linguagem como meio de criação e simultânea cicatrização, do processo de construção de uma verdade a partir da rememoração, as temáticas de Santiago e Jogo de cena nos remetem àquilo que um dia dissera Benjamin a respeito de Proust: "Um acontecimento vivido é finito (...) ao passo que o acontecimento lembrado é sem limites" (1994:37). Seja por meio do bovarismo e do apreço ritualístico de Santiago, o personagem (uma dança com as mãos, uma reza em latim, a contrição diante do passado), seja por meio das performances da memória das personagens de Jogo de cena, em ambos os filmes trata-se de narra-dores, cujas imaginações, por vezes melodramáticas (Baltar, 2005), carregam consigo um potencial de autoconstrução estética, de libertação, mas também de paradoxal prisão. Afinal, como bem sabe o ex-mordomo Santiago e as mulheres de Coutinho, esses habitantes do mundo da linguagem, porém nunca perfeitamente contidos nele, a imaginação é o que nos salva, mas também o que nos condena.

Tensionando a atualidade da vida às suas possibilidades imaginativas e narrativas, a reflexividade presente em Santiago e Jogo cena, isto é, o pensamento em ato do filme sobre si próprio, não se vincularia ao distanciamento crítico que marcara as modernas estratégias antiilusionistas, mas, diferentemente, a uma espécie de engajamento crítico. É a partir desse engajamento que a dimensão afetiva da reflexão sobre o método soma-se à sedução emocional do espectador, o qual se engaja na situação implicada tanto pelo efeito-câmera quanto pelas performances - da retórica, dos gestos e da memória - diante da câmera. Sendo assim, no lugar de nossos velhos conhecidos efeitos de verdade, talvez esteja em jogo aqui a produção de "afetos de verdade", pois não se trata de julgar os personagens em nome de uma instância superior (que seria o bem, a verdade), mas de avaliá-los em relação à vida e à intensidade que suas presenças e suas performances implicam. "O afeto como avaliação imanente, em vez do julgamento como valor transcendente" (Deleuze, 2005:172).

Neste ponto, cabe lembrar que o elogio a essa vital e, simultaneamente, performática capacidade de afetação dos personagens no cinema de Coutinho está sempre sob o risco da mais banal instrumentalização e "rentabilização da performance" (Eduardo, 2011), comprometida com a eficiência cênica posta em marcha pelos espetáculos massivos e televisivos, para os quais o corpo social é uma espécie de arena onde o que está em jogo, o que se mobiliza e disputa, é a mise en scène mais convincente, a confissão surpreendente, a autenticidade, a capacidade de produzir empatia e, por que não, "se auto-inventar" (França, 2009). O interesse que se vê em 
Jogo de cena, sob essa perspectiva, é de que maneira, ao dialogar com a cultura do confessional-midiático, o filme não só não se reduz a ela como toma uma contramão contundente, em que as tensões com nossa experiência social, histórica e cultural jamais são dissolvidas.

O próprio Eduardo Coutinho não nega que busque personagens "extraordinários", como tão explicitamente, e muitas vezes espantosamente ${ }^{34}$, percebemos em Edifício Master (2002); ou relações que criem "intimidade", como ocorre em O fim e o princípio (2005), em que Coutinho, pela primeira vez não guiado por uma pesquisa prévia (marca de seu método), abandona um personagem que, sendo incapaz, em uma primeira aproximação, de exprimir algo de pessoal, de "íntimo", fala apenas sobre questões de trabalho - um tópico já tão fora da pauta do audiovisual contemporâneo $^{35}$. Sem dúvida, nesse método movido pela recusa ao que é "representativo" (o outro como representação ou síntese social), de um lado, e pela vontade de afirmação de sujeitos singulares e fabuladores (por meio de performances e auto-encenações), de outro, as questões relativas ao mundo público do trabalho perdem sua expressividade e seu lugar social como definição das identidades.

É significativo como, nesse sentido, enquanto em Santiago o narrador corajosamente expresse que o mal-estar que se interpôs, durante as filmagens, entre diretor e personagem deveu-se a uma insidiosa relação de classe que nunca permitiu que Santiago deixasse de ser o mordomo da família e Salles o filho do patrão, em Jogo de cena nenhuma das personagens fale sobre questões de ordem pública, como de suas profissões ou de projetos de realização que ultrapassem o mundo privado da família e dos sentimentos autênticos (autênticos?). Se o melodrama burguês caracterizava-se justamente pela separação entre o mundo público e privado (Xavier, 2003), alçando o

\footnotetext{
${ }^{34}$ Ainda que Edifício Master seja um filme importantíssimo para a cinematografia brasileira e um ponto de inflexão determinante na trajetória de Eduardo Coutinho, hoje, quase uma década após seu lançamento, as entrevistas realizadas por Coutinho e sua equipe com os moradores do edifício de Copacabana parecem-nos excessivamente roteirizadas, programadas, tornando explícita uma relação de poder notadamente desproporcional (afinal, Coutinho sabe muito sobre seus personagens enquanto eles nada sabem sobre Coutinho) e uma vontade de mise-en-scène dos personagens em nada econômica ou minimalista. Tanto o "minimalismo" estético de Coutinho quanto a relação de proximidade com os entrevistados, respeitosa e supostamente "igualitária" (isto é, a entrevista como arte do "encontro"), foram virtudes extremamente valorizadas pela crítica de então. $\mathrm{O}$ que não significa dizer que a crítica estava equivocada, mas que estava respondendo (como usualmente acontece) a um momento histórico anterior.

${ }^{35}$ Como toda tendência traz consigo suas exceções, no documentário Vigias (Marcelo Lordello, 2010), o diretor, em seu primeiro longa-metragem, acompanha a rotina noturna e solitária de funcionários e porteiros que fazem a vigilância de prédios de classe-média na cidade do Recife. Em sua última sequência, ao acompanhar durante as primeiras horas da manhã o retorno de um dos vigilantes até a porta de sua casa na periferia da cidade, a câmera se recusa a entrar no espaço doméstico do personagem, permanecendo fixamente diante de sua porta - em um gesto tão consciente quanto político.
} 
privado a um espaço de singularização e reconciliação, Jogo de cena, em mais uma contramão, joga com a publicização do privado e com a partilha coletiva daquilo que seria, a princípio, individual e intransferível, como as "autênticas" histórias de uma vida.

Marcado desde meados dos anos 90 pela presença de discursos particularizantes, em um movimento de redução do enfoque (Mesquita, 2010) que coincide com o retorno de Coutinho ao cinema com Santo forte (1997), o documentário brasileiro recente tem assim de se haver com as contradições e os paradoxos inerentes ao esvaziamento de sentido que o mundo público do trabalho conferia, por meio do cinema e dos cineastas, aos citadinos em décadas anteriores, como as de 60 e 70 - momento em que foram realizados no país os importantes ensaios sociológicos, aqui sem nenhuma conotação negativa, A opinião pública (Arnaldo Jabor, 1965), Viramundo (Geral Sarno, 1965) e Maioria absoluta (Leon Hisrzman, 1964) ${ }^{36}$.

Assim, seja por meio de um movimento de autocrítica social e da capacidade fabulatória de Santiago, o personagem (essa capacidade que nunca dissocia o privado da política), seja por meio da desestabilização da relação entre fala, expressão subjetiva e relato testemunhal de histórias de uma vida, isto é, da desestabilização da própria noção de sujeito (e de tudo o que nele seria intransferível), como se dá em Jogo de cena, o cinema sempre pode inventar novas formas de partilha, de comunidade e coletividade, sem com isso se desfazer da diferença. A coletividade de que se fala não pressupõe, portanto, homogeneidade, mas uma relação de não-propriedade - cujas partes entrem em relação pela diferença e não por uma pretensa "identidade" -, marcada por múltiplas e dialógicas vozes.

Com isso, não significa fazer o elogio de um cinema e de um momento histórico em detrimento de outro, mas partir de modos e critérios de avaliação que sejam empregados no corpo a corpo com os filmes, por meio da atenção ao modo pelo qual as

\footnotetext{
${ }^{36}$ Analisados pelo crítico Jean-Claude Bernardet em Cineastas e imagens do povo (2003), originalmente escrito em 1984, esses dois últimos filmes, junto a outros do período, tiveram seus métodos caracterizados como "modelo sociológico", em uma apreciação francamente crítica e questionadora da legitimidade (autoritária e paternalista) dos cineastas de então em falar do nome do outro, em nome do povo. Historicamente distanciados do calor desse debate e vivendo hoje as mazelas de um movimento cultural de vetores contrários (quando artistas e cineastas, no geral, quando não se omitem, se esquivam do confronto e do conflito), podemos, na revisão desses filmes de nosso passado recente, perceber que aquilo que tem sido identificado como "sociológico" pode ser compreendido como uma organização de forte inflexão ensaística: a partir da explicitação de uma enunciação reflexiva (que toma posição, dialoga com o espectador, assume sua historicidade), não necessariamente "onisciente" ou "generalizante", e da assunção de uma postura mais comprometida em arrolar hipóteses de trabalho do que em comprovar uma "tese" pré-determinada - termos empregados pela crítica a esse modelo (que de certo modo o expurgou de nossa cinematografia).
} 
formas estéticas se articulam às formas e forças culturais e sociais, bem como pela observância das metodologias em jogo. Sendo, portanto, as distintas metodologias de Santiago e Jogo de cena dimensões integrantes dos processos de ambos os filmes, e não somente suas instâncias a priorísticas, como em um documentário mais tradicional, deve-se compreender aquilo que chamamos de método como um conjunto de regras diegéticas e procedimentos estéticos sobre o qual trabalhará, afetiva, reflexiva e experimentalmente, o documentarista.

Espécie de método que contempla um tipo de busca que sempre encontra algo distinto do que procura, na medida em que encontrar não significa chegar a um ponto estável e estático, cujos sentidos estariam estabilizados, mas voltear, rodeando um centro móvel e apenas intuído, o ensaio, como queria Blanchot (apud Brasil, 2006:153), é, de fato, um dis-cursus, curso interrompido ou aberto à mudança. "Mais do que uma certeza acerca do mundo, o pensamento ensaístico nos levaria a errar sobre o mundo e, sobretudo, a suspeitar do mundo", escreve André Brasil em "Ensaio de uma imagem só" (2006:152). Assim, verbalizando sua suspeita, nos diz o narrador de Santiago: "Hoje, treze anos depois, é difícil saber até onde íamos em busca do quadro perfeito, da fala perfeita. O que fica claro é que tudo deve ser visto com uma certa desconfiança”,37.

Nesse sentido, ainda que em Santiago a "errância" e o caráter "inacabado" próprios ao gesto ensaístico sejam, diferentemente de Jogo de cena, bastante controlados e autoconscientes, tanto uma obra quanto outra, cada qual a seu modo e na sua intensidade, cultivam incertezas e desconfianças por todo o filme: destilam dúvidas a respeito da imagem documental, perturbam a crença do espectador naquilo a que se está assistindo e estilhaçam as noções de autêntico, verdadeiro e espontâneo, tão comumente remetidas ao campo do documentário - como nos lembram Consuelo Lins e Claudia Mesquita (2008), ao analisarem, além de Santiago e Jogo de cena, outros dois filmes brasileiros contemporâneos que lidam com a questão da suspeita, tais como Juízo (Maria Augusta Ramos, 2007) e Serras da desordem (Andrea Tonacci, 2006).

Longe, portanto, da ilusão do lugar do controle, de quem crê poder sempre saber, julgar e decidir, posição cara aos espectadores (tornados "atores") de toda sorte de jogos televisivos, telejornais, mensagens publicitárias e dispositivos interativos, o ensaio se moveria, como já o "definiu” a ensaísta portuguesa Silvina Rodrigues Lopes, "segundo um impulso de aventura" (2003:165): aquele impulso que, contaminado pelo mundo e

\footnotetext{
37 Ver FELDMAN, Ilana. "Santiago sob suspeita". Trópico. ago-set, 2007. Disponível em:
} http://pphp.uol.com.br/tropico/html/textos/2907,1.shl 
aberto à instabilidade do devir, não poderia se decidir pelo verdadeiro, somente por uma verdade contingente. Tal impulso seria justamente a função das "potências do falso", postuladas por Deleuze (2005) na defesa dos cinemas modernos, em que o falso, entendido não como um erro, uma falha ou uma confusão, operaria como uma potência que, ao ultrapassar a alternativa real/fictício, tornaria o verdadeiro indecidível. O que se opõe, portanto, à ficção não é o real, não é a verdade, que, segundo Deleuze, é sempre a dos dominantes, mas é a função fabuladora. E, para que tal função seja exercida,

É preciso que a personagem seja primeiro real, para afirmar a ficção como potência e não como modelo: é preciso que ela comece a fabular para se afirmar ainda mais como real, e não como fictícia. A personagem está sempre se tornando outra, e não é mais separável desse devir que se confunde com o povo (2005:185).

Ancorados na experiência subjetiva e sensível, seja a de seu autor-narrador, caso explícito de Santiago, seja a de seus outramentos, caso implícito de Jogo de cena, o qual não se utiliza de uma escritura em primeira pessoa, tanto o pensamento que se ensaia quanto o cinema-ensaio seriam então marcados pela aventura da transitividade e por uma "erótica das imagens" (Ménil, 2004), em que os sentidos se dão mais por contaminação epitelial do que por relação causal, como ocorre explicitamente com as relações sensíveis propostas pela montagem de Jogo de cena. É a contagiosa instabilidade e indeterminação inerente ao ensaio o que proporcionará, portanto, os trânsitos e as passagens entre o singular e o coletivo, a memória e a atualidade, o privado e político, a vida e sua historicidade - que não se desvincula do lugar e da função do cinema.

\section{Na contramão do confessional: a impossibilidade de acesso à "verdade" e ao "real"}

Em um momento histórico marcado por uma hipertrofia da subjetividade, ancorada em um verdadeiro mercado de narrativas em primeira pessoa e (auto)biografias, quando a ênfase no âmbito privado, considerado mais autêntico e verdadeiro do que o público, faz com que a exposição da intimidade e a declaração de uma unívoca "verdade sobre si" sejam tiranicamente requeridas e demandadas, Santiago e Jogo de cena, por meio da opção pelo ensaísmo documental, em que, como vimos, está em jogo o privilégio da opacidade, a explicitação da mediação e a tensão entre as subjetividades e seus horizontes ficcionais, livram-se da estabilidade e da unidade de 
"eus já acabados", escovando a contrapelo "a eloquiência do confessional midiático" (Bruno, 2007).

Essa forma de astúcia ${ }^{38}$ parece dialogar criticamente, conscientemente ou não, com o "regime da autenticidade" (Sennet, 2002) baseado na crença na personalidade como valor, posto em marcha no momento de formação das sociedades burguesas, a partir do desenvolvimento do capitalismo industrial em meados do século XVIII. Nesse contexto de emergência do melodrama como código narrativo hegemônico, com seu teatro das emoções autênticas em que tudo se deveria expressar (lógica antagônica, por exemplo, às noções de recato e decoro que Santiago encena), a histórica concepção do interior do sujeito como lugar privilegiado da autenticidade e da verdade é reforçada. Tal perspectiva, que se tornara fundamental na cultura moderna, hoje estaria em mutação, em função de tendências confessionais exibicionistas e performáticas, exteriorizadas nas superfícies das peles e das telas, de acordo com o argumento do livro O show do eu - a intimidade como espetáculo, de Paula Sibilia (2008).

Das confissões de Agostinho nos séculos IV e V, o inventor das primeiras metáforas cristãs da introspecção e da auto-exploração, passando pela secularização da idéia de interioridade por meio das virtudes auto-reflexivas da escrita ensaística de Michel de Montaigne no século XVI, ao regime da autenticidade na criação de si e na interação com os outros, pleiteado pelas confissões de Jean-Jacques Rousseau em meados do século XVIII, poderíamos afirmar que aquilo que modernamente foi se consolidando como a intimidade burguesa, espaço privado onde residiria a verdade mais recôndita de cada um de nós, é colocado em xeque, e no centro da cena, por Santiago e Jogo de cena.

Assim, enquanto Eduardo Coutinho coloca, em Jogo de cena, a cena na sede por excelência do espetáculo, o teatro ${ }^{39}$ - pela primeira vez, aliás, em sua obra,

\footnotetext{
${ }^{38}$ Tal astúcia ou esquiva estratégica comparece no documentário Só dez por cento é mentira (Pedro Cezar, 2009), supostamente uma biografia fílmica do poeta pantaneiro Manuel de Barros. Mas eis que Manuel de Barros não é um indivíduo biografável, como ele próprio diz, e o filme então assimila em sua estrutura narrativa essa impossibilidade constitutiva, dividindo a trajetória do poeta em três infâncias. De uma de suas infâncias, Manuel proclama com zombaria: "Tenho uma confissão a fazer: noventa por cento do que escrevo é invenção. Só dez por cento do é mentira".

${ }^{39}$ Valeria a pena notar aqui o parentesco de Jogo de cena com seu primo distante Salve o cinema (1995), em que, a partir de um anúncio no jornal convocando atores para seu próximo filme, o diretor o iraniano Mohsen Makhmalbaf transforma o teste de elenco no próprio corpo do filme, não sem ambigüidades, autoritarismo do diretor e uma série de indeterminações. Já mais distante no tempo e fora do espaço do teatro, mas lidando com a indeterminação entre pessoa e personagem, vida e cena, A paixão de Ana (1970), de Ingmar Bergman, apresenta quatro interrupções (interlúdios, segundo Bergman) na diegese da narrativa, nas quais cada um dos quatro protagonistas discorre, diretamente para a câmera e num tom confessional, sobre suas atuações e seus personagens, sem com isso abrir mão da ambigüidade entre
} 
descontextualizando os espaços sociais e geográficos em que habitam seus personagens -, em Santiago, João Salles se recusa a ouvir a mais importante e íntima "confissão" de seu ex-criado Santiago - "E no fim, quando Santiago tentou falar do que lhe era mais íntimo, eu não liguei a câmara", nos diz o narrador -, esquivando-se estrategicamente, ainda que também autoritariamente, da revelação de um segredo que, possivelmente, conferiria ao ex-mordomo uma verdade e uma identidade inescapáveis.

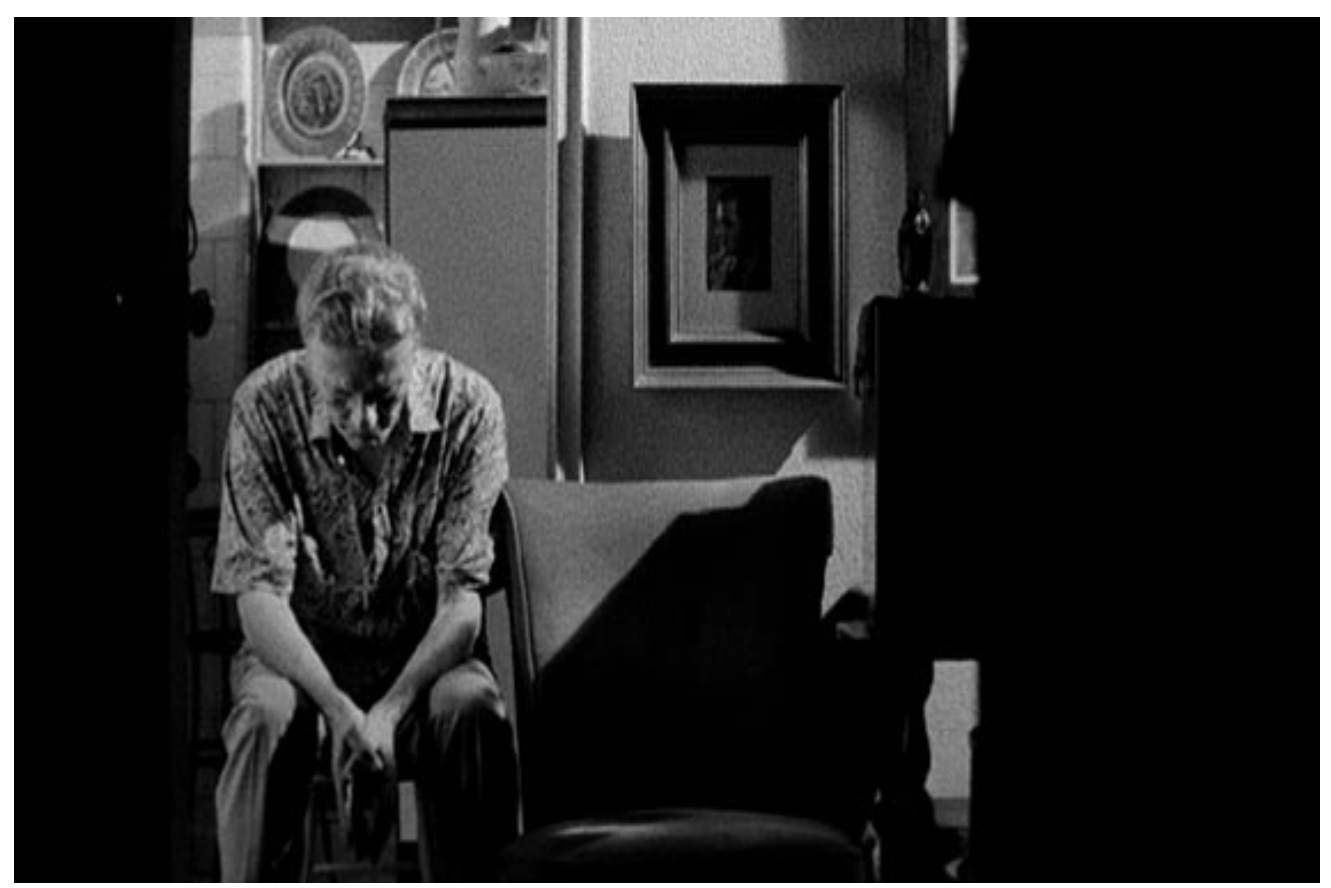

Como tão bem diagnosticara Michel Foucault, em fins dos anos 70, no primeiro volume de A História da Sexualidade - a vontade de saber, nascida no âmbito medieval e eclesiástico e, posteriormente, apropriada pelos saberes e poderes jurídicos e médicos, a confissão foi tornada nos séculos XIX e XX a prática nuclear em torno da qual gravitavam as ciências humanas, especialmente a psicanálise. Dessa forma, "a confissão da verdade se inscreveu no cerne dos procedimentos de individualização pelo poder" (1997:58), poder que, ao incitar a proliferação discursiva sobre o desejo, alçou a verdade e o sexo, ou a verdade do sexo, à expressão obrigatória de um segredo individual.

No entanto, é sempre saudável relativizar os poderes totalitários e tirânicos da confissão. Ainda que a leitura tão audaz e cirúrgica de Foucault seja ainda hoje extremamente pertinente, justamente em um momento histórico em que, segundo Paula comentando seus personagens ou se são os personagens comentando as dificuldades dos atores. 
Sibilia, a confíssão teria se tornado midiática ${ }^{40}$, brilhando com novas roupagens nas telas eletrônicas da internet e da televisão (2008:108), seria bom suspeitar das capacidades revelatórias da confissão em produzir e extrair verdades inquestionáveis. $\mathrm{O}$ próprio Foucault, aliás, admite discretamente: “(...) o essencial sempre nos escapa e ainda é preciso, mais uma vez, partir à sua procura” (1997:35).

Escapando às "tiranias da intimidade" (Sennet, 2002), ainda tão caras a nossa época $^{41}$, enquanto Santiago, o filme, recusa a confissão e a intimidade (em seu sentido mais rebaixado) de Santiago, o personagem, em um gesto que se poderia chamar de emancipador, Jogo de cena ultrapassa o próprio sentido do que seria a esfera do íntimo, do singular e do intransferível. Pois, duplicando-se, desdobrando-se e transferindo-se de um corpo para o outro, como se os corpos fossem veículos de uma comunicação contagiosa, as múltiplas vozes femininas de Jogo de cena passam a habitar singularmente cada gesto, cada entonação, cada rosto, tal como espécies da grega Helena, "uma e toda mulher" (Cassin, 2000). Uma $e$ toda mulher, cabe enfatizar, não significa uma mulher una.

Em Santiago, a primeira e a última palavra que ouvimos do documentarista João Salles (e não do narrador do filme) é um inequívoco “não!”. No início, Salles recusa um pedido de Santiago por um "depoimento", mesmo que "com todo o carinho". Ao final, ele recusa um pedido de Santiago por uma “confissão". Se então Salles começa e termina seu filme com uma negativa é porque, tanto em Santiago, o filme, como em Santiago, o personagem, o que ele não-é é o que mais é nele. Misto de copista medieval e colecionador moderno, a um só tempo borgeano e viscontiano, Santiago viveu a vida por meio de um bovarismo às avessas. Ao invés de consumir avidamente folhetins burgueses, tal como a personagem de Flaubert, Emma Bovary, cuja imaginação a levou

\footnotetext{
${ }^{40}$ Blogs, flogs, redes de relacionamento como Facebook, Orkut, My Space..., A lista dos permanentemente renovados dispositivos confessionais é infindável, e, ainda que vivamos sob o paradigma de um ocaso de nossa interioridade psicológica moderna (como defendem alguns autores), cenário em que as neurociências e as descrições fisicalistas da vida mental ganham cada vez mais importância e mobilizam investimentos cada vez mais vultosos, é digno de nota que a indústria do entretenimento continue trabalhando na chave do "divã": caso da bem-sucedida série de TV "In treatment" (HBO) e do grande sucesso de público brasileiro, "O divã” (José Alvarenga Jr., Globo Filmes, 2009).

${ }^{41}$ Certamente, muitos documentários brasileiros recentes têm procurado escapar dessas "tiranias da intimidade", recusando certa "fome biográfica" dominante. Bruta aventura em versos (Letícia Simões, 2011), primeiro longa-metragem da diretora, por exemplo, não é um retrato da poeta Ana Cristina Cesar, mas uma carta endereçada a ela. E, enquanto carta, o filme não quer repor nenhuma verdade faltante, nenhuma síntese artística, histórica ou biográfica. Ana Cristina Cesar permanece como enigma, esfinge sem segredo a ser revelado. Um "claro enigma", como poderia dizer Drummond. Sobre a questão dos "retratos dialógicos", ver também os filmes analisados por Claudia Mesquita: MESQUITA, Cláudia. "Retratos em diálogo - notas sobre o documentário brasileiro recente". In: Novos estudos CEBRAP, n.86, março 2010.
} 
a desistir da vida, Santiago escolheu viver, ainda que como mordomo, a vida que imaginava. Vinculou sua existência não aos valores burgueses - baseados, como vimos, na valorização do âmbito privado da vida, com sua crença na idéia de intimidade e autenticidade -, mas aos atributos de um momento histórico decerto já pretérito.

Habitante de um mundo nobre e aristocrático erigido por uma noção oitocentista de "homem público", fundada no valor da arte, dos artifícios e dos rituais (uma dança com as mãos, uma reza em latim), Santiago era um admirador da distinção, do decoro, da ritualística dos gestos e da tradição. E tradição, para o ex-mordomo, significava uma ligação afetiva com um tipo de ancestralidade inventada, que transcendia sua história familiar e biográfica. Ao partilhar tal contrição diante do passado (ainda que se trate de um passado inventado), Santiago, o filme, por meio de um rigor formal recatado e decoroso, se empenha em captar e expressar os sentimentos de permanência e de lentidão tão caros a Santiago, o personagem.
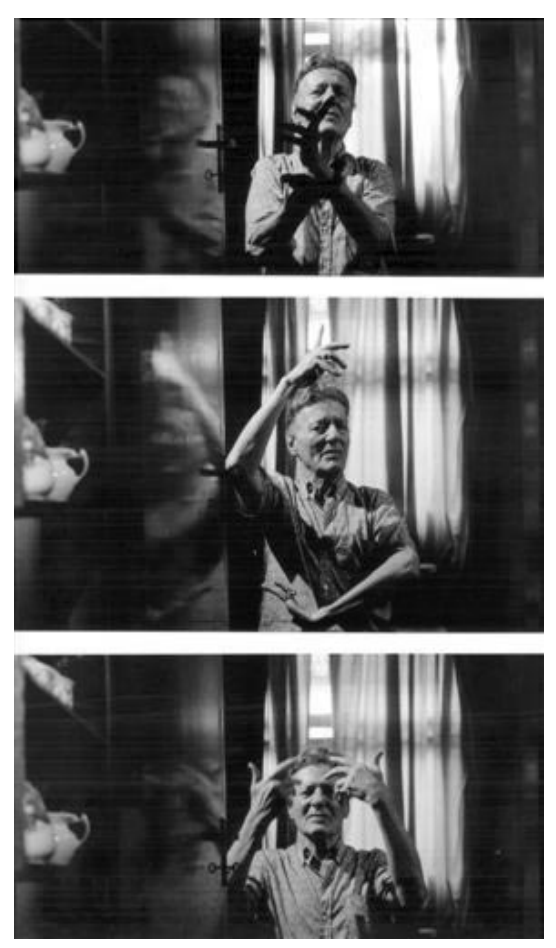

Em um mundo cada vez mais acelerado, pautado pelo curto-prazo e tiranizado pela intimidade, Santiago permanecia em seu apartamento como uma espécie de guardião da memória e da perenidade. Durante mais de 50 anos, tendo inventariado a aristocracia da humanidade e construído sentidos para sua existência a partir de propósitos aparentemente sem razão e sem função, Santiago passou a vida lutando para que seus personagens não fossem esquecidos. Na lógica do filme, Santiago faz por seus 
“mortos insepultos", por seus "personagens tétricos", aquilo mesmo que João Moreira Salles, o efetivo protagonista do filme, faz por Santiago.

Assim, tanto Santiago, esse personagem-outramento de Salles, através do qual o cineasta traça uma espécie particular de alterbiografia, quanto as memórias das personagens de Coutinho, essas "hospedeiras da fala" (Bernardet, 2008), aparecem como aquilo que acessa, por meio de depoimentos confessionais, potências nãoindividuais, não-psicológicas. Se o desafio de toda escritura é o de levar a vida a "a uma potência não pessoal" no esteio do que tanto pleiteava Deleuze (1998:63), as narradoras de Jogo de cena e o personagem de Santiago alçariam a vida a essa possibilidade, como quem se lança à aventura de perder seu rosto (os rostos das personagens, o rosto do filme).

Longe de estarem comprometidas com os regimes de verdade estabelecidos pelas modernas e disciplinares técnicas hermenêuticas de produção subjetiva, as práticas confessionais presentes em Santiago e Jogo de cena estariam, sobretudo, vinculadas à invenção e atualização de memórias, em uma espécie de resgate do sentido etimológico e inaugural da aletheia grega: verdade como desocultamento, verdade como negação do esquecimento. A memória, em Santiago e em Jogo de cena, é desmesurada, aquém e além do indivíduo: em Santiago é a potência de abertura para o mundo, para os vários mundos contidos no pequenino e povoado apartamento de Santiago; em Jogo de cena é maneira de multiplicar, e contaminar pela indiscernibilidade, os sujeitos da enunciação.

Contudo, se a recusa é o modo pelo qual a "confissão" de Santiago, o personagem, é inviabilizada por Santiago, o filme (por meio não apenas do "não!" proferido por João Salles, mas também do preto que encobre sua imagem, já que o diretor não ligou a câmera), cabe salientar que não se trata de, simplesmente, valorizar a interdição $^{42}$ da confissão, como se dá no caso de Santiago. Até porque, ambiguamente, se o filme como obra inviabiliza a confissão de seu personagem, a voz off do narrador de Santiago não deixa de expiar uma culpa em uma jornada rumo a um esclarecimento e a uma possibilidade de redenção final, no sentido da transformação existencial (e inegavelmente cristã) de seu narrador. A recusa à confissão, portanto, compreendendo a confissão como prática de inscrição dos sujeitos em um dispositivo de poder comprometido com a produção de discursos verídicos, pode se dar, justamente, a partir

\footnotetext{
${ }^{42}$ No vídeo Carlos Nader (1998), o videoartista e cineasta Carlos Nader promete confessar para a câmera o segredo mais íntimo de sua vida. Contudo, no momento mesmo da confissão, o som é completamente abafado, interditado, e o que se vê a partir daí é um fluxo de imagens ora oníricas e aparentemente desconexas, ora empenhadas em construir um ensaio sobre a identidade como máscara.
} 
da estratégia oposta àquela da interdição. Em Jogo de cena, como vimos, tal recusa é efeito da proliferação discursiva e do compartilhar biográfico entre as personagens de Coutinho, em uma explicitação do caráter coletivo e social de toda enunciação.

Na contramão, portanto, da secularização e, mais recentemente, da midiatização das práticas confessionais, é notável como em Santiago e em Jogo de cena as dimensões confessionais e biográficas escapam, com intensidade, dos limites privados, pessoais e individuais da existência humana para ganharem o mundo, para se tornarem, por meio da linguagem e de sua potência fabuladora, "enunciações sem propriedade" (Migliorin, 2007). Enunciações "desapropriadas" que não elidem a irredutibilidade e materialidade da vida nem se confundem à profusão dos clichês midiáticos, à "fala de todo mundo", que, em realidade, apenas cala. Dessa forma, nos dois filmes em questão, a linguagem verbal performativa e fabular é justamente aquilo que, ao contingencialmente singularizar o sujeito, ultrapassa a dimensão pessoal e privada de sua singularidade.

Se, como dizia Foucault,

\begin{abstract}
a confissão difundiu amplamente seus efeitos: na justiça, na medicina, na pedagogia, nas relações amorosas, na esfera mais cotidiana e nos ritos mais solenes; confessam-se os crimes, os pecados, os pensamentos e os desejos, confessam-se passado e sonhos; confessa-se a infância; confessam-se as próprias doenças e misérias; emprega-se a maior exatidão para dizer o mais difícil de ser dito; confessa-se em público, em particular, aos pais, aos educadores, ao médico, àqueles a quem se ama; fazem-se a si próprios, no prazer e na dor, confissões impossíveis de se confiar a outrem, com o que se produzem livros $(1997: 59) \ldots$
\end{abstract}

...e tantos filmes, poderíamos acrescentar, essa dimensão confessional presente em Santiago e Jogo de cena é, portanto, de outra ordem. Fazendo assim essa passagem do singular ao coletivo, do privado ao político, do regime da autenticidade à autoficção e da memória à atualização, por meio de gestos e métodos reflexivos, Santiago e Jogo de cena estão a serviço do colocar em cena corpos que não se reduzem a invólucros de identidades, mas à intensidade de conexões, diferenças e relações.

Nesse sentido, admitir, junto com Comolli, que "filmar é filmar relações, inclusive as que faltam" (2007:130) é também acolher o pressuposto de que a diferença, a separação e o corte no cinema são a condição mesma de todo enlace. Nessa experiência fílmica partilhada, os gestos de Santiago, o solitário e povoado personagem de Salles, e os rostos das narradoras de Coutinho, atravessadas pelo paradoxo da visibilidade e do isolamento, do espetáculo e da solidão, parecem não suportar mais a desmesura de um mundo que os atravessam pelo excesso e os destituem pela ausência. 
Daí a necessidade do cinema e de toda narrativa; daí a condição excessiva, mas simultaneamente incompleta e esquiva ${ }^{43}$, do documentário.

$\mathrm{Na}$ busca pelas imagens, pelas palavras e pela composição precisa, que não deixa, porém, de dar atenção aos resíduos, aos restos, às hesitações e aos gestos abandonados, aqueles que normalmente são relegados ao esquecimento de um copião ou de um rascunho rasurado, o ensaio fílmico, bem como o texto ensaístico, "termina onde sente ter chegado ao fim, não onde nada mais resta dizer" (Adorno, 2003:17). Incompleto, inadequado e, no limite, impossível, o ensaio não pode acessar "a verdade" e o "real" das coisas, das gentes e do mundo. Ao ensaio, sempre errático e errante, entre a melancolia e a ironia, só é dada a possibilidade de começar pelo "erro" 44 , pois sempre parte e sempre chega a uma negatividade fundadora.

Em Santiago, a primeira palavra que ouvimos do documentarista João Moreira Salles, e não do narrador do filme, é um inequívoco "não!": uma recusa a um primeiro pedido do ex-mordomo Santiago. Em Jogo de cena, a última imagem a que assistimos é a de uma cadeira vazia, sobre um palco igualmente vazio: lá onde somos apenas bons ou maus narradores. Tanto a recusa de Salles quanto a cadeira vazia de Coutinho sintetizam a negatividade inaugural de que parte o sujeito e a linguagem. Como está lá em Barthes (1984), em seu belo ensaio sobre a fotografia de sua adorada mãe: morte, ausência ou não-ser como ser da imagem.

\footnotetext{
${ }^{43}$ Alguns curtas-metragens brasileiros contemporâneos têm conseguido, com imenso talento, operar deslocamentos importantes no campo das retóricas testemunhais e confessionais, trabalhando a partir da opacidade do relato, seus incômodos, seus limites e suas lacunas. Essa potente esquiva atravessa de formas diversas a beleza de Ovos de dinossauro na sala de estar (Rafael Urban, 2011), a inteligência graciosa de Vó Maria (Tomás von der Osten, 2011) e o assombro de Oma (Michael Wahrmann, 2011), três exemplos de filmes em que a questão alteridade no documentário é radicalmente problematizada, resistindo, com seus efeitos de presença, a ser interpretada, domesticada e subordinada.

${ }^{44}$ Tal como ensina a "ensaísta" GH, para quem o erro é um de seus fatais modos de trabalho: "E não me esquecer, ao começar o trabalho, de me preparar para errar (...), pois só quando erro é que saio do que conheço e do que entendo" (Lispector, 1998:109).
} 


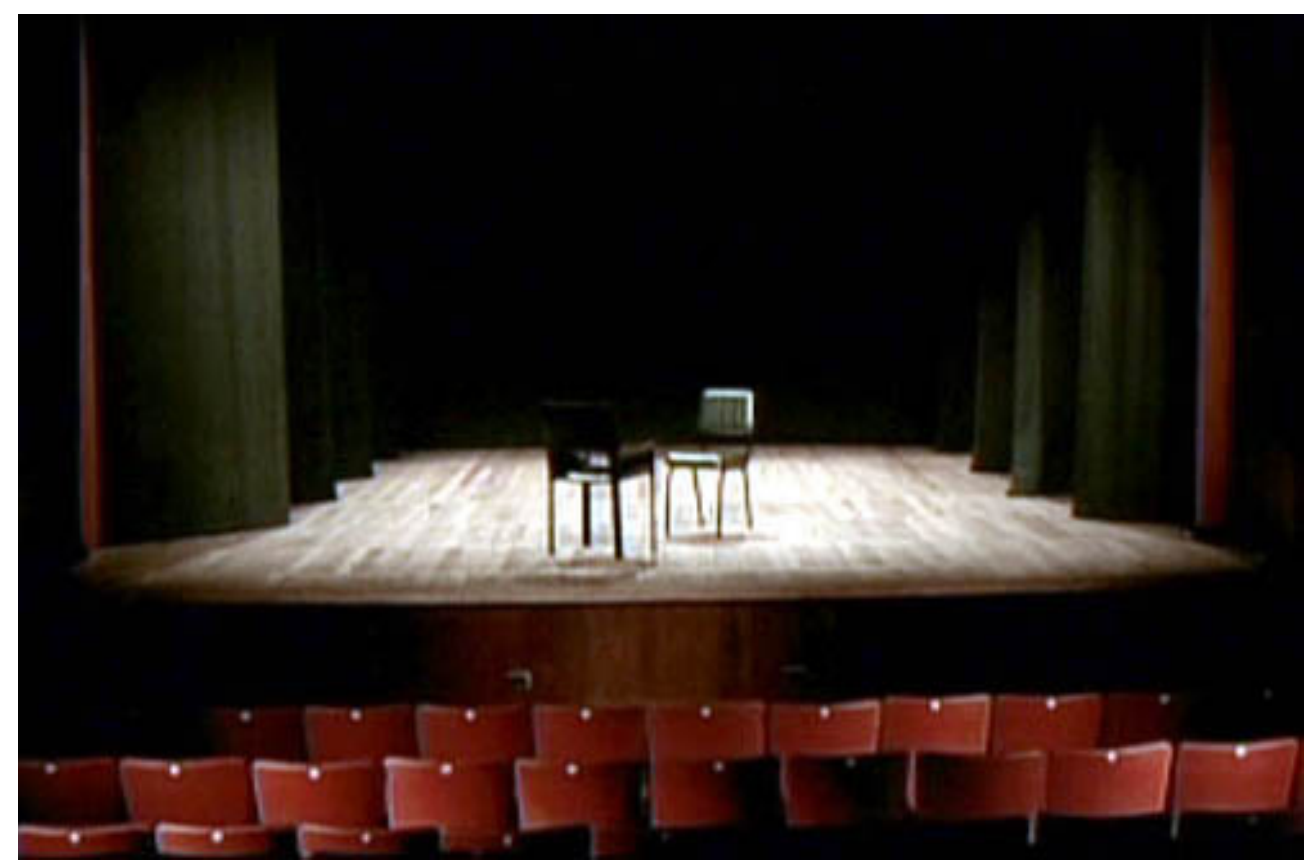

$*$

Seria confortável encerrar este texto de uma forma, digamos, bonita. Aliás, a própria Clarice Lispector, tantas vezes citada e cuja obra contempla uma envergadura a um só tempo literária e filosófica, costumava dizer que achar bonito é um indireto modo de compreensão. No entanto, há que se desconfiar quando o conforto e o pensamento crítico se dão as mãos. Por isso, cabe uma suspeita final: talvez as pessoas que mais franqueiam e exponham publicamente suas intimidades, a verdade de seus corpos e de seus sexos (seja em reality shows, sites de relacionamento na internet, vídeos caseiros no Youtube ou outras "plataformas de sociabilidade"), talvez as pessoas que, portanto, mais se confessam, sejam as mais cientes - conscientes ou não - de que suas intimidades residem em outro lugar. Lá onde somos ainda irredutíveis, irredutivelmente opacos. Lá onde somos mais aquilo que em nós não-é. 


\section{Filmografia trabalhada}

Jogo de cena, de Eduardo Coutinho (RJ, 107', 2007)

Santiago, de João Moreira Salles (RJ 79’, 2007)

\section{Filmografia comentada}

Bruta aventura em versos, de Letícia Simões (RJ, 76', 2011)

Carlos Nader, de Carlos Nader (SP, 17’, 1998)

Edifício Master, de Eduardo Coutinho (RJ, 110', 2002)

Moscou, de Eduardo Coutinho (RJ, 80’, 2009)

Oma, de Michael Wahrmann (Uruguai/Brasil, SP, 22', 2011)

Ovos de dinossauro na sala de estar, de Rafael Urban (PR, 12', 2011)

A paixão de Ana, de Ingmar Bergman (Suécia, 101', 1970)

Salve o cinema, Mohsen Makhmalbaf (Irã, 75', 1995)

Só dez por cento é mentira, Pedro Cezar (RJ, 76', 2009)

Vigias, de Marcelo Lordello (PE, 70’, 2010)

Vó Maria, de Tomás von der Osten (PR, 6', 2011)

\section{Filmografia mencionada}

Entreatos, de João Moreira Salles (RJ, 117', 2004)

O fim e o princípio, de Eduardo Coutinho (RJ, 110', 2005)

Maioria absoluta, de Leon Hirszman (SP, 16', 1964)

Nelson Freire, de João Moreira Salles (RJ, 102', 2002)

A opinião pública, de Arnaldo Jabor (RJ, 71', 1965)

Santo forte, de Eduardo Coutinho (RJ, 80’, 1997)

Viramundo, de Geraldo Sarno (SP, 45’1965) 


\section{Referências bibliográficas}

ADORNO, Theodor. "O ensaio como forma". In: Notas de Literatura I. São Paulo: Editora 34 e Duas Cidades, 2003.

ANDRÉ, Serge. Que veut une femme? Paris: Éditions du Seuil, 1995.

ASSIS, Machado de. Dom Casmurro. São Paulo: Editora Globo, 1997.

BALTAR, Mariana. "Pacto de Intimidade - ou possibilidades de diálogo entre o documentário de Eduardo Coutinho e a imaginação melodramática". Artigo apresentado no XIV Encontro da Compós - GT Fotografia, Cinema e Vídeo, Niterói, RJ, 2005.

BARTHES, Roland. "O efeito de real”. In: O rumor da língua. São Paulo: Martins Fontes, 2004. A câmera clara. Rio de Janeiro: Nova Fronteira, 1984.

BENJAMIN, Walter. "A imagem de Proust". In: Magia e técnica, arte e política. São Paulo: Brasiliense, 1994.

BERNARDET, Jean-Claude. "Jogo de cena", 14/01/2008. Disponível no "Blog do JeanClaude", em: http://jcbernardet.blog.uol.com.br/ . Cineastas e imagens do povo. São Paulo: Cia das Letras, 2003.

BRAGANÇA, Felipe. "Mestres dos mestres". Revista eletrônica Contracampo, 2004. Disponível em: http://www.contracampo.com.br/58/jeanrouch.htm

BRASIL, André. "Ensaios de uma imagem só". In: Devires, Belo Horizonte, v.3, n.1, jan-dez., 2006.

"A tela em branco: da origem do ensaio ao ensaio como origem". Trabalho apresentação ao GT Fotografia, Cinema e Vídeo, XVIII Encontro Anual da Compós, Puc-BH, Belo Horizonte, MG, 2009.

BRUNO, Fernanda. "Jogo de cena", 2007. Disponível no blog "Dispositivos de visibilidade e subjetividade contemporânea", em: http://dispositivodevisibilidade.blogspot.com/2007/11/jogode-cena.html

CAETANO, Daniel. "Um fantasma se movimenta - o vazio em Moscou como gesto, idéia e presença". Cinética, set. 2009. Disponível em: http://www.revistacinetica.com.br/moscoucae.htm

CASSIN, Bárbara. Voir Helène em toute femme. Paris: Institut Sanofi-Synthélabo, 2000.

COMOLLI, Jean-Louis. Ver e poder: a inocência perdida - cinema, televisão, ficção, documentário. Belo Horizonte: UFMG, 2008.

. "Os homens ordinários. A ficção documentária". In: $O$ comum e a experiência da linguagem. GUIMARÃES, C.; OTTE, G.; SEDLMAYER, S. (orgs.). Belo Horizonte: UFMG, 2007.

"Não pensar o outro, mas pensar que o outro me pensa - entrevista com JeanLouis Comolli”. In: Revista Devires, Belo Horizonte, v.02, n.01, jan-dez. 2004.

DAHLET, Patrick. "Dialogização enunciativa e paisagens do sujeito". In: BRAIT, Beth (org.). Bakhtin - dialogismo e construção do sentido. Campinas: Ed. UNICAMP, 2008. 
DA-RIN, Silvio. "Verdade e imaginação". In: Espelho partilho - tradição e transformação do documentário. Rio de Janeiro: Azougue, 2004.

DESCARTES, René. Descartes, Vida e Obra. Coleção Os Pensadores. São Paulo: Ed. Nova Cultural, 2004. Trad. Bento Prado Jr.

DELEUZE, Gilles. "Postulados da lingüística”. In: Mil Platôs, Vol.II. São Paulo: Ed.34, 1995. .As potências do falso". In: A Imagem-Tempo. SP: Editora Brasiliense, 2005. .GUATTARI, Felix."Devir-intenso, devir-animal, devir imperceptível". In: Mil Platôs, Vol.IV. São Paulo: Ed.34, 2004.

São Paulo: Escuta, 1998. .PARNET, Claire. "Da superioridade da literatura anglo-americana". In: Diálogos.

DETIÈNNE, Marcel. Os mestres da verdade na Grécia arcaica. Rio de Janeiro: Jorge Zahar, 1993.

EDUARDO, Cléber. "O modelo egológico e a rentabilidade cênica em Estamira e A pessoa é para o que nasce", dissertação de mestrado apresentada ao Programa de Pós-Graduação em Ciências da Comunicação, ECA / USP, 2011.

."Subjetividade mediada: entre a classe social e a família universal". Revista Cinética, mar., 2007. Disponível em: http://www.revistacinetica.com.br/santiagocleber.htm

FELDMAN, Ilana. "Na contramão do confessional: o ensaísmo em Santiago, de João Moreira Salles, Jogo de cena, de Eduardo Coutinho, e Pan-cinema permanente, de Carlos Nader". In: MIGLIORIN, Cezar (org.) Ensaios no Real. Rio de Janeiro: Azougue, 2010.

"Santiago sob suspeita". Trópico. ago-set, 2007. Disponível em: http://pphp.uol.com.br/tropico/html/textos/2907,1.shl ."O apelo realista". In: Revista FAMECOS, Dossiê Menções de Destaque Compós 2008”, Porto Alegre, n.36, 2008. Disponível em: http://revcom2.portcom.intercom.org.br/index.php/famecos/article/viewFile/5472/4970 "Moscou: do inacabamento ao filme que não acabou". Revista Cinética, abril de 2009. Disponível em: http://www.revistacinetica.com.br/moscouilana

FERRAZ, Maria Cristina Franco. "Teatro e máscara no pensamento de Nietzsche" e "O simulacro e suas implicações em Deleuze, Nietzsche e Kafka”. In: Nove variações sobre temas nietzschianos. Rio de Janeiro: Relume Dumará, 2002.

"Verdade-mulher, amor e amizade em Nietzsche". In: AZEVEDO, Vânia Dutra (Org.). Falando de Nietzsche. Ijuí: Unijuí, 2005, p. 115-129.

FOUCAULT, Michel. História da sexualidade, vol.1, A vontade de saber. Rio de Janeiro: Graal, 1997.

FRANÇA, Andréa. "O documentário entre a cena do tribunal e a cena do teatro". Trabalho apresentado ao XVIII Encontro Anual da COMPÓS, PUC-MG, Belo Horizonte/BH, 2009.

GUIMARÃES, César. "A singularidade como figura lógica e estética no documentário". In: Revista Alceu, vol.07, n.13, jul./dez. 2006, p.38 a 48.

LINS, Consuelo. O documentário de Eduardo Coutinho. Rio de Janeiro: Jorge Zahar, 2004.

LINS, Consuelo; MESQUITA, Cláudia. "Crer, não crer, crer apesar de tudo - a questão da crença nas imagens na recente produção documental brasileira". Trabalho apresentado ao XVII Encontro Anual da Compós - GT Fotografia, Cinema e Vídeo. UNIP, São Paulo, SP, 2008.

LISPECTOR, Clarice. A paixão segundo GH. Rio de Janeiro: Rocco, 1998. 
Água viva. São Paulo: Editora Círculo do Livro, 1976.

LOPES, Silvina Rodrigues. "Do ensaio como pensamento experimental". In: Literatura, defesa do atrito. Lisboa: Vendaval: 2003.

LORAUX, Nicole. Les mères en deuil. Paris: Seuil, 1990.

KEHL, Maria Rita. Deslocamentos de feminino. Rio de Janeiro: Imago, 2008.

MENDONÇA, Alexandre Ferreira. "Nietzsche e a Ficção da Verdade". Tese de Doutorado apresentada ao Programa de Pós-Graduação em Filosofia da UFRJ. Rio de Janeiro. Rio de Janeiro: 2004.

MÉNIL, Alain. "Entre utopie et héresie: quelques remarques à propôs de la notion d'essai". In: LIANDRAT-GUIGNES, Suzanne; GAGNEBIN, Murielle (orgs.) L'essai e le cinéma. Paris: Champ Vallon, 2004.

MESQUITA, Cláudia. "Retratos em diálogo - notas sobre o documentário brasileiro recente". In: Novos estudos CEBRAP, n.86, março 2010.

MIGLIORIM, Cezar. "Jogo de cena - de Eduardo Coutinho (2)". Disponível no blog "Polis + Arte", 2007. Disponível em: http://a8000.blogspot.com/2007/10/jogo-de-cena-de-eduardocoutinho-2.html

PRADO Jr., Plinio Walder. "Confessions (III) - Structure du Double". Texto de apresentação do curso de mesmo nome, no âmbito da Faculdade de Filosofia da Universidade Paris 8, ocorrido em 2008/2009.

ROSSET, Clément. O princípio da crueldade. Rio de Janeiro: Rocco, 1989.

SARLO, Beatriz. Tempo passado - cultura da memória e guinada subjetiva. São Paulo: Cia das Letras; Belo Horizonte: Ed. UFMG, 2007.

SENNETT, Richard. O declínio do homem público - as tiranias da intimidade. São Paulo: Cia das Letras, 2002.

SENRA, Stella. "Perguntar (não) ofende - anotações sobre a entrevista: de Gláuber Rocha ao documentário brasileiro recente". In: MIGLIORIN, Cezar. Ensaios no Real. Rio de Janeiro: Azougue, 2010 (no prelo).

SEVERINO, Antonio Marcos Vieira. "Pequenas notas sobre o ensaio". In: Revista História UNISINOS, vol. 08, n.10, julh./dez., p. 97-106, 2004.

SIBILIA, Paula. O show do eu - a intimidade como espetáculo. Rio de Janeiro: Nova Fronteira, 2008.

SIQUEIRA, Marília Rocha de. "O ensaio e as travessias no cinema documentário". Dissertação apresentada ao Programa de Pós-Graduação em Comunicação Social da Faculdade de Filosofia e Ciências Humanas da Universidade Federal de Minas Gerais, jun. de 2006.

STAROBINSKI. Jean. "Peut-on défini l'Essai?" In: BONNET, Jacques (org.). Jean Starobinski. Collection cahiers pour un temps. Paris: Centre Pompidou, 1985.

TODOROV, Tzvetan. "Os homens-narrativas" e "Introdução ao verossímil". In: Poética da Prosa. São Paulo: Martins Fontes, 2003. 
XAVIER, Ismail. O olhar e a cena - Melodrama, Hollywood, Cinema Novo, Nelson Rodrigues. São Paulo: Cosac\&Naify, 2003.

"Teoria e história no estudo de cinema no Brasi - entrevista a Adilson Mendes". In: Ismail Xavier. MENDES, Adilson (org.) Rio de Janeiro: Azougue, 2009.

."El exemplar y lo contingente en el teatro de las evidencias", revista Pensamiento de los Confines v.25, Buenos Aires, 2009.

"Indagações em torno de Eduardo Coutinho e seu diálogo com a tradição moderna". In: MIGLIORIN, Cezar (org.) Ensaios no real. Rio de Janeiro: Azougue, 2010. 
CAPítulo II 


\title{
A indeterminação sob suspeita:
}

\author{
Filmefobia (Kiko Goifman, 2009) e Pan-cinema permanente (Carlos Nader, 2008)
}

\section{Indeterminação}

Quando a privacidade torna-se publicidade, quando a experiência torna-se jogo e quando a vida torna-se performance, estamos diante de um investimento biopolítico na vida, em sua força plástica, modulável e inesgotável, continuamente destinada a ser capturada e escapar, a se adequar e resistir, a ser otimizada e fracassar. Se as outrora estatais biopolíticas, tais como definidas por Michel Foucault em fins dos anos 70, nascem como uma modalidade de poder sobre a vida e de governo da vida, hoje, privatizada e hiper-individualizada, a biopolítica pode ser compreendida como uma forma de gestão, instrumentalização e modulação dos indivíduos em meio à indeterminação entre autonomia e sujeição, prazer e controle, liberdade e restrição.

Nesse panorama, identificar os modos pelos quais opera a indeterminação, nos campos artístico e político, faz-se uma tarefa das mais urgentes. Pois, se de um lado a indeterminação, a ambigüidade e a instabilidade podem ser tomadas, como vimos no capítulo anterior, como potências estéticas, potências que ultrapassariam as oposições dicotômicas mais simplórias advindas do antigo preconceito segundo o qual essência/aparência, profundidade/superfície, verdade/ilusão e realidade/ficção seriam valores opostos, mutuamente excludentes, de outro, as figuras da indeterminação, sedutoras e ardilosas, permitem que nos desvencilhemos, um tanto comodamente, do enfrentamento de toda contradição.

Transitando dessa forma nos indeterminados interstícios de categorias como ficção e documentário, pessoa e personagem, autenticidade e encenação, experiência e jogo, vida e performance, um número crescente de filmes brasileiros, sobretudo aqueles tomados por documentais (ou falsamente documentais), assim como toda sorte de dispositivos comunicacionais e audiovisuais contemporâneos, dos reality shows aos vídeos pessoais na internet, das redes sociais aos games, têm em feito da indeterminação, da performance e do jogo estratégias privilegiadas de invenção ou 
simulação de mundos ${ }^{45}$. No bojo dessa cultura audiovisual não apenas midiática, mas também sintomática, atravessada por clichês, capturas e reduções, alguns filmes brasileiros recentes tentam dialogar, crítica ou ironicamente, com a busca pelo efeito de verdade pautado tanto por estratégias outrora reflexivas quanto por práticas autoficcionais. Para tanto, fazem do princípio de incerteza $a^{46}$ o motor da narrativa: investem na opacidade, na explicitação das mediações e na problematização das próprias prerrogativas, destilando dúvidas a respeito da imagem documental (Lins; Mesquita, 2008), colocando sob suspeita seus procedimentos ou produzindo suas próprias falsificações e esquivas.

Nesse contexto, em que poderíamos mencionar os filmes Jogo de cena (Eduardo Coutinho, 2007) e Santiago (João Salles, 2007), já analisados no capítulo anterior, e acrescer a eles os indeterminados Girimunho (Clarissa Campolina e Helvécio Marins, 2011), O céu sobre os ombros (Sérgio Borges, 2010), Avenida Brasília Formosa (Gabriel Mascaro, 2010), Morro do Céu (Gustavo Spolidoro, 2010), Moscou (Eduardo Coutinho, 2009), Juízo (Mara Augusta Ramos, 2007) e Serras da desordem (Andréa Tonacci, 2006), para citarmos alguns dos mais instigantes exemplos, seria possível destacar também Pan-cinema permanente (Carlos Nader, 2008) e Filmefobia (Kiko Goifman, 2009), foco de nosso interesse. Como veremos, ainda que Pan-cinema permanente seja um documentário atravessado por uma dimensão autoficcional e performativa de seu personagem e Filmefobia uma ficção de forte apelo documental igualmente autoficcional e performativo, oferecendo-nos uma plêiade de pressupostos muito próximos, no que se refere a seus efeitos políticos eles estariam absolutamente distanciados. Como diria a máxima foucaultiana, trata-se aqui de "práticas semelhantes e sentidos distintos".

\footnotetext{
${ }^{45}$ É importante lembrar que o documentário, como gênero ou campo de práticas diversas, já nasce indeterminado, advindo de um contexto histórico em que os conceitos de realidade e ficção estavam completamente amalgamados - afinal, essas categorias e os gêneros a elas correlatos foram historicamente forjados. Sobre o cinema dos primeiros tempos em geral e a mistura de ficção e não ficção engendrada pelas "atualidades reconstituídas", ver COSTA, Flávia Cesarino. O primeiro cinema espetáculo, narração, domesticação. Rio de Janeiro: Azougue: 2005. Quanto ao nascimento do "documentário" em particular, cujo marco é o filme Nanook do Norte (Robert Flaherty, 1922), exemplo paradigmático do hibridismo entre a ideologia documental (proveniente dos primórdios da fotografia) e os modos de representação ficcional (baseados em uma estrutura dramática), ver DA-RIN, Silvio. "O protótipo de um novo genro". In: O espelho partido - tradição e transformação no documentário. Rio de Janeiro: Azougue, 2004.

${ }^{46}$ Originalmente tributário da Física moderna, o princípio de incerteza poderia ser assim traduzido pelo vaqueiro Riobaldo, em Grande Sertão: Veredas, de Guimarães Rosa: "Eu quase que nada não sei. Mas desconfio de muita coisa."
} 
Enquanto Pan-cinema permanente investe nas performances mediadas e nas autoficções de Waly Salomão, explorando a radical opacidade que se instala entre o poeta, a câmera e o mundo, ao mesmo tempo em que parte de uma busca, quase romântica, pela verdade da imagem, uma imagem que teria de ser não-performática (busca que, desde o início, se revelará fracassada), Filmefobia encena ser um filme sobre o processo de registro do filme a que estamos assistindo, simulando a busca por uma imagem e por uma "experiência" (em seu sentido comportamental) verdadeiras: "A única imagem verdadeira é a do fóbico diante de sua fobia”, nos diz Jean-Claude, o personagem, idealizador dos experimentos behavioristas e, mesmo, biopolíticos, que acompanharemos a partir de então (e que, de outro modo, também fracassarão).

Tanto Pan-cinema permanente como Filmefobia, a despeito de suas evidentes diferenças estéticas e de seus distintos efeitos políticos, atuam em um horizonte de instabilidade, ambigüidade e indeterminação - como a tensão que se instaura entre vida e teatro, autêntico e encenado, espontâneo e construído. No entanto, se as potências da indeterminação, da ambiguidade e do falso (Deleuze, 2005), operando enquanto potências estéticas, podem ser marcas de um cinema que se reconhece, de alguma forma, como crítico aos poderes e saberes dominantes (sempre aferrados em reduzir toda complexidade em posição dicotômica), a figura da indeterminação, esquiva, sedutora e ardilosa, também pode ser pensada como aquilo que, justamente, legitima a incidência do poder sobre a vida em situações de exceção. Nesse sentido, cabe notar que se a indeterminação não garante a efetividade das potencialidades estéticas do cinema, tal como a desestabilização dos códigos e gêneros narrativos ou um movimento em direção ao filme ensaio, por exemplo, no que tange ao campo político, a figura da indeterminação tem condicionado os diagnósticos mais sombrios ${ }^{47}$. Como enfatiza o filósofo Vladimir Safatle, em Cinismo e falência da crítica, "a indeterminação tornou-se um padrão hegemônico de normatização social” (2008:16).

Como, portanto, conciliar o paradoxo de que um procedimento potente esteticamente pode operar de modo tão impotente politicamente? Como conciliar o

\footnotetext{
${ }^{47}$ De acordo com Safatle, "Hegel foi o primeiro a compreender que a modernidade, por sua força de erosão de formas tradicionais de vida, podia abrir espaço para a indeterminação e para o esvaziamento de toda substancialidade normativa do social”. Como demonstra Safatle, tal diagnóstico hegeliano converge com as descrições sociológicas que associam a própria Modernidade à generalização de situações de anomia e indeterminação. Ver SAFATLE, Vladimir. Cinismo e falência da crítica. São Paulo: Boitempo, 2008. p. 15
} 
paradoxo de que as "potências da indeterminação",48 - essa presença, em todo sujeito e em toda obra, daquilo que não se submete integralmente às determinações identitárias podem ser politicamente tão impotentes? Mas o paradoxo não é justamente o terreno do inconciliável e do irresolúvel? Eterno impasse na ordem de toda doxa, para a qual a linguagem deveria remeter a um sentido único. Se, manter-se na paradoxalidade significaria impedir o sentido de se fixar, quer como afirmação, quer como negação, posição que implicaria estar à altura de todo risco e perigo, é porque, segundo Gilles Deleuze, "o bom senso é a afirmação de que, em todas as coisas, há um sentido determinável; mas o paradoxo é a afirmação dos dois sentidos ao mesmo tempo" (2003:01).

Contrariando, portanto, o bom senso, é preciso - ao assumir todo o risco e perigo - pensar contra si mesmo, como já sugeriram alguns filósofos: questionar (nossos próprios) valores, desnaturalizar (nossos próprios) pressupostos, se desfazer como sujeito. É preciso reconhecer que, se a política opera esteticamente, tal como defende Jacques Rancière (2004), nem toda estética e nem toda crítica operariam politicamente. Portanto, a suspeita deveria recair não apenas sobre as imagens, essencialmente ambíguas $^{49}$, mas também sobre os discursos críticos que têm legitimado a potência esquiva da indeterminação, acima de qualquer suspeita. Pois em nome de toda sorte de indistinção e descontrole nos processos de criação estética e plasticidade subjetiva, o princípio da indeterminação acaba muitas vezes por pré-determinar, roteirizar e agenciar estrategicamente as ambigüidades que derivam desse caráter supostamente indeterminado.

De início, o primeiro passo para que pensemos contra nós mesmos talvez seja privilegiar objetos, em suas obscuridades ou assombros, menores, medíocres, mundanos, e não apenas objetos que nós, críticos, amamos. Objetos que nos são, por assim dizer, contemporâneos, no sentido proposto por Giorgio Agamben (2008). Para o

\footnotetext{
${ }^{48}$ No que concerne à psicanálise, as "potências da indeterminação" seriam justamente aquilo que permite ao sujeito acessar uma experiência no limite da despersonalização. Conforme aponta Vladimir Safatle, "para Lacan, a falta própria ao desejo é, na verdade, o modo de descrição de uma potência de indeterminação e de despersonalização que habita todo sujeito". Ver SAFATLE, Vladimir. "Confrontarse com o inumano". Dossiê Jacques Lacan, revista Cult, 125, ano 11, 2008.

${ }^{49}$ Defensor do caráter "ontogeneticamente" realista da imagem fotográfica em seu clássico ensaio "Ontologia da imagem fotográfica", o crítico André Bazin também acreditava que a fotografia, através da objetividade de seu método de reprodução mecânica e fotoquímica, ao testemunhar a existência das coisas transferiria a ambiguidade da realidade para a imagem - e que esta restituiria, portanto, a ambiguidade do movimento do mundo a nossa atenção. Ver BAZIN, André. "Ontologia da imagem fotográfica". In: Ensaios. São Paulo: Brasiliense, 1991.
} 
filósofo, a contemporaneidade seria uma singular e paradoxal relação com o próprio tempo, que adere a este ao mesmo tempo em que dele toma distância, por meio de uma perpétua defasagem ou de um anacronismo. Assim, aqueles que coincidem muito plenamente com sua época, que em todos os aspectos a ela aderem, não são contemporâneos, porque, exatamente por isso, não conseguem vê-la, não conseguem fixar o olhar sobre ela. Contemporâneo seria então aquele que mantém fixo o olhar em seu tempo, para nele perceber não as luzes, mas a obscuridade. Todos os tempos seriam, portanto, para quem deles experimenta a contemporaneidade, obscuros (2008:19).

O interessante de tal perspectiva é o fato de que justamente a obscuridade ou a opacidade constitutiva de nossa contemporaneidade produzirá, como veremos logo adiante, uma (pós)ideologia da transparência e do não ocultamento, em que os poderes explicitam suas normas e injunções - muitas vezes duais e paradoxais - rindo reflexivamente de si mesmos. Nesse sentido, fazendo coro às palavras de Siegfried Kracauer (2008), colocadas em prática em seus ensaios sobre manifestações da cultura aparentemente tão diminutas, mas que prefiguraram certa Alemanha, os objetos culturais mais obscuros são aqueles que apontam para qual direção estamos indo, como se através deles recebêssemos em pleno rosto, no dizer de Agamben, o facho das trevas que provém de nosso tempo ${ }^{50}$. A crítica, portanto, não deveria apenas se comprazer em ser "a arte de amar", como se consagrara a célebre definição do crítico Jean Duchet (1961), pois, como já dizia a sabedoria popular, o amor é cego.

\section{Cinismo e jogo}

Se é então preciso suspeitar de nossos próprios pressupostos, suspeitemos, primeiramente e a título explicativo, do princípio do prazer. Em um sábado do mês de janeiro de 2009, embalando o caderno Ilustrada, do jornal Folha de São Paulo, via-se a seguinte publicidade da montadora BMW: "Prazer. Essa é a palavra sobre a qual construímos uma empresa. Independente e compromissada com apenas uma pessoa, o motorista [você]. Não construímos carros. Construímos emoções (...)”. Ora, é fato que uma empresa não vende um produto, mas o mundo em que esse produto habita, um mundo de valores, de sensações, de códigos, de determinações. Mas o que espanta aqui é o fato de essa formulação - "Não construímos carros. Construímos emoções" - vir por

\footnotetext{
50 Tal como diz Agamben, em nossa tradução: "Contemporâneo é aquele que recebe em pleno rosto o
} facho das trevas que provém de seu tempo" (2008:22). 
escrito, explicitada, embalando ironicamente o caderno, supostamente de cultura, de um jornal. O que diz então tal enunciado? O que significa uma montadora que diz que não vende carros?

Este é um típico e exemplar enunciado cínico, poderia dizer Vladimir Safatle, pois sustenta, tal qual um paradoxo, sua própria contradição, sem com isso se destituir de validade. Segundo Safatle, "o paradoxo deriva do fato de que uma concretização aparentemente contrária à intenção da norma que a gerou pode ser adequada a essa mesma intenção" (2008:14). Assim, ao se anular ou suspender, justamente para se manter integralmente, o enunciado da BMW mantém sua força e veemência. De acordo com o filósofo, essa seria a lógica de uma época considerada pós-ideológica, em que, em vez de o sistema econômico justificar-se ou esconder seus efeitos nocivos, assumeos ironicamente e esvazia a crítica "de fora", produzindo, com isso, uma ideologia da transparência e do não mascaramento. Uma ideologia reflexiva, tal como esse enunciado que se anula sem com isso ser abalado, justamente porque, no âmbito político, o paradoxo, a indeterminação e o cinismo - por meio da assimilação de estruturas normativas duais em detrimento do enfrentamento das contradições - em vez de colocarem o sistema em crise, acabam por ser a base de sua manutenção. Não seria, portanto, o cinismo um "estado de exceção do enunciado", para nos valermos do conceito tão trabalhado por Giorgio Agamben?

O estado de exceção, identificado por Agamben (2004) em seu livro homônimo, seria a suspensão total ou parcial dos direitos constitucionais com o objetivo de manter a ordem constitucional, ou seja, a suspensão total ou parcial da lei (qualquer que seja ela) visando à manutenção da própria lei. O importante nesse gesto de Agamben é o fato de que, de figura jurídica, o estado de exceção passaria a operar como lógica gerencial e política, afigurando-se nas democracias modernas como um patamar, justamente, de indeterminação. Por isso, o estado de exceção não se restringe a práticas políticojurídicas, mas se realiza como gestão - política, social e policial - da vida em um contexto de indeterminação entre práticas democráticas e aquelas totalitárias, a partir das quais os cidadãos dos Estados ditos democráticos são persuadidos a aceitar como naturais práticas de controle que sempre foram consideradas excepcionais.

Cabe aqui ressaltar que o estado de exceção não se afigura como uma metáfora ou como uma analogia, sendo antes a forma política por meio da qual a indeterminação opera social e - por que não? - culturalmente. Tomemos como exemplo privilegiado, ou modelo operatório, o reality show Big Brother Brasil, compreendido como um 
dispositivo libidinal e policial de gestão da vida (Feldman, 2008) que absorve o código e sua negação, a norma e sua transgressão, na medida em que, simultaneamente, estimula e controla, libera e restringe, premia e pune - em uma dinâmica movida a álcool, prazer e vigilância ${ }^{51}$. Nessa indeterminação entre os apelos da vida real e o desejo de artifício, entre a liberação libidinal e a restrição policial, modulada pelas lógicas do jogo e da gestão, é fácil perceber o modo pelo qual a tirania de um poder absolutamente verticalizado (do Big Brother ele mesmo, das Organizações Globo etc.) convive em perfeita "naturalidade" com as interativas e colaborativas práticas democráticas que o exercício do voto possibilita à audiência.

Desse modo, a partir da convergência de poderes aparentemente contrários, assim como de mídias heterogêneas (na medida em que o programa mobiliza ao mesmo tempo televisão aberta e fechada, telefonia fixa e móvel, internet, mídia impressa e todo o tipo de pornografia), a felicidade e a liberdade de cada participante se inscreverão no ponto exato de sua própria submissão. É tal indiscernibilidade entre autonomia e sujeição, prazer e controle, liberdade e restrição, jogo e gestão, modulada pelos poderes ou biopoderes contemporâneos, aquilo que permite, justamente, que um sujeito demande seu próprio assujeitamento à imagem na esperança de que deixe de ser sujeitado, ou que um personagem se submeta a todo tipo de constrangimento e humilhação a fim de se emancipar pela conquista da visibilidade: caso de tantos dispositivos midiáticos e biopolíticos contemporâneos, como os reality shows e certos quadros de programas de auditório; caso de alguns documentários, supostamente autoirônicos e debochados, e por isso um tanto mais perversos, como Jesus no mundo maravilha (Newton Cannito, 2007) e Alô, alô, Terezinha (Nelson Hoineff, 2009) ${ }^{52}$.

\footnotetext{
${ }^{51}$ Foi a partir das imagens de vigilância veiculadas pelo sistema pay-per-view que o participante da $12^{\mathrm{a}}$ edição do Big Brother Brasil, Daniel, fora acusado de ter estuprado uma colega de confinamento (que estaria desacordada após intensa bebedeira) na madrugada do dia 15 de janeiro de 2012. O caso, de extrema repercussão midiática, foi parar nas bancadas dos telejornais e na delegacia de polícia, tendo Daniel sido expulso do programa e acusado penalmente por estupro. Impossibilitado de aparecer e se defender publicamente (em função do tipo de contrato firmado com a Globo), é curioso como os advogados de defesa de Daniel não querem simplesmente extirpar a acusação que pesa sobre o rapaz, mas trabalham para que ele retorne ao reality show, pois é só ali, na arena da visibilidade pública e midiática, que Daniel pode reverter - ou seja, gerir de uma outra forma - sua imagem. Sobre as polêmicas sexuais que tem movido o Big Brother em todo o mundo, ver matéria publicada na Folha de São Paulo, Ilustrada, em 22 de janeiro de 2012, por Rodrigo Levino.

${ }^{52}$ Cabe notar que aproximar os dois documentários citados não significa compará-los. Jesus no mundo maravilha é, apesar ou em função de suas perversidades, extremamente inventivo na manipulação do som em relação à montagem e nos modos, mesmo que cínicos, de auto-problematização do filme e de seu realizador: uma obra, portanto, que não pode ser desprezada - o que já não ocorre com Alô alô Terezinha (um filme sobre a vida sexual de ex-chacretes e seus parceiros), tamanha a simploriedade de suas operações. Sobre Jesus no mundo maravilha, ver também GUIMARÃES, César; LIMA, Cristiane. Crítica da montagem cínica. In: Doc On-line, n.07, dezembro 2009. Disponível em: www.doc.ubi.pt
} 
Novamente, é preciso lembrar aqui que demandar seu próprio assujeitamento à imagem na esperança de que deixe de ser sujeitado ou se submeter a todo tipo de constrangimento e humilhação a fïm de se emancipar pela imagem não são ações metafóricas de indivíduos hipotéticos ou vislumbres apocalípticos de críticos inflamados. Voltando ao modelo operatório do programa Big Brother Brasil - há 12 anos veiculado com extremo sucesso de público e patrocínio ${ }^{53}$ pela Rede Globo e um formato narrativo já enraizado do ocidente ao oriente -, em 2005 fora publicado na Folha de São Paulo a seguinte nota, "Para Globo, 'big brother' é personagem", 54 , por meio da qual se tornava pública a decisão da TV Globo em "patentear" a personalidade dos participantes do programa, que, a partir de então, seriam juridicamente considerados personagens de ficção.

Contratados como tais, os participantes estariam impedidos (em até 60 dias após o término do programa) de se auto-encenar ou de "interpretar" seus próprios tipos em outros meios e veículos, recebendo o mesmo tratamento jurídico dado aos atores profissionais, os quais não podem interpretar em anúncios os personagens que encarnam na ficção, pois a autoria de tais personagens pertence à empresa e ao autor que os criou. Questão que se coloca: como adaptar esse contrato a uma situação em que pessoa e personagem, vida e cena, performance e produto, estão completamente amalgamados e indeterminados? Como adaptar esse contrato a uma situação em que a "obra", o "produto", se confunde à própria vida? De quem é, afinal, a autoria? De acordo com a notícia publicada, a autoria de cada "personagem" - isto é, a personalidade construída publicamente, em relação e em reação às câmeras, por cada um - passaria a pertencer ao programa de TV.

Assumindo então contratualmente a ficcionalização das identidades proporcionada pelo programa, identidades agora capitalizadas pela empresa e tornadas, literalmente, uma mercadoria, o Big Brother Brasil, entendido como uma tecnologia e

\footnotetext{
${ }^{53}$ De acordo com a coluna de Daniel Castro, hospedada no portal de internet R7 (em sete de abril de 2010), "a décima edição do Big Brother Brasil rendeu aos caixas da Globo pouco mais de R $\$ 340$ milhões em receitas, batendo outro recorde do reality show". Com mais de 120 ações de merchandising validadas (sem contar aquelas em que "vazam" as marcas de produtos cujos fabricantes pagam para entrar no confinamento, como shampu e protetor solar), as receitas poderiam ser ainda maiores, se a Globo não tivesse recusado diversos pedidos de inserção de merchandising, porque o programa já estava sobrecarregado e novos anúncios poderiam comprometer seu andamento. Disponível em: http://noticias.r7.com/blogs/daniel-castro/2010/04/07/em-3-meses-big-brother-fatura-o-mesmo-que-sbtem-meio-ano/

54 Jornal Folha de São Paulo, Caderno Ilustrada, coluna de Daniel Castro, 22 de março de 2005. Disponível em: http://www1.folha.uol.com.br/fsp/ilustrad/fq2203200504.htm
} 
uma pedagogia de gestão da vida em um contexto de indeterminação, operaria o seguinte deslocamento: na impossibilidade de a vida "anônima" e "real" se reconhecer como sujeito de direito, na impossibilidade de a vida se reconhecer como "personagem jurídico", ela demandaria (por meio de sua voluntariedade e risco) ser tornada um personagem fictício - cuja imagem, ao revés, lhe restituiria sua identidade jurídica e política. Nesse contexto, enquanto personagens fictícios, a privacidade e a intimidade dos participantes desse dispositivo de convivialidade vigiada seriam tomadas, portanto, como um efeito da visibilidade conquistada (e não uma instância previamente dada), o que esvaziaria juridicamente o fundamento constitucional segundo o qual a intimidade e a privacidade, além de serem dimensões invioláveis, não podem ser vendidas ou disponibilizadas.

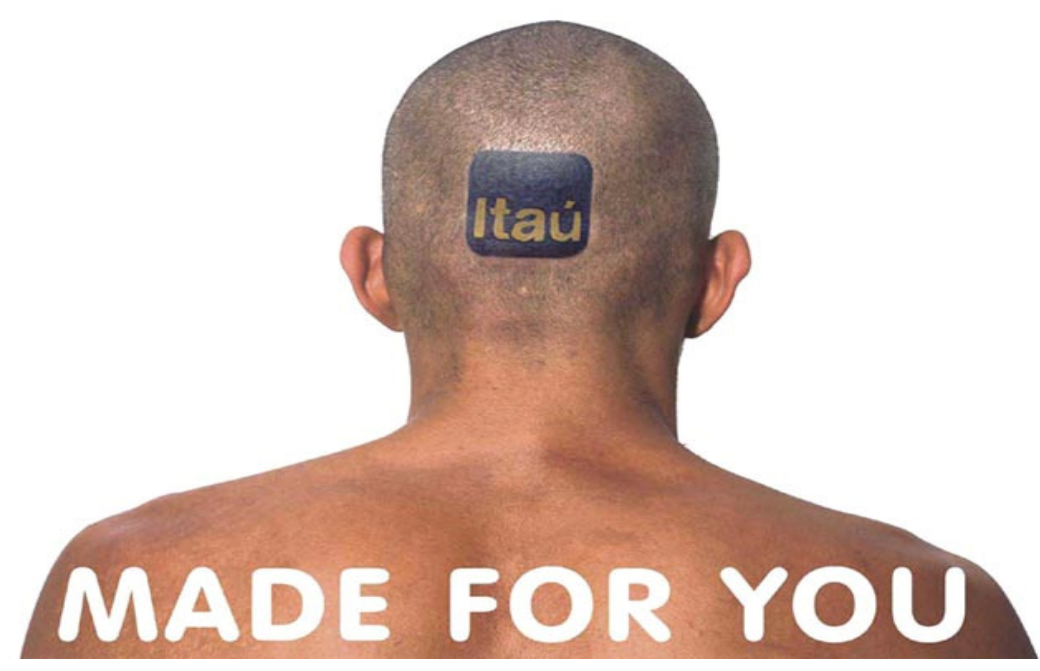

A perversidade desse tipo de dispositivo contratual (de exceção e possivelmente anticonstitucional) está no fato de que ninguém é coagido ou forçosamente impelido a dele tomar parte. Muito ao contrário: disponibilizar voluntariamente a vida, mercantilizá-la, geri-la como um "capital pessoal" "55 a ser cuidadosamente administrado,

\footnotetext{
${ }^{55}$ Com a "obra" Made for You (2002), como vemos na imagem acima, o artista plástico Ducha provoca, um tanto cinicamente, reflexões e desconcertos tanto relação à voluntariedade auto-empreendedora da vida e sua captura pelas marcas e pelo dinheiro quanto aos modos de financiamento da própria arte que está sendo feita, no caso, com dinheiro do Instituto Itaú Cultural (obtido por isenção fiscal). Sobre o polêmico contexto da obra, ver http://www.polemica.uerj.br/pol17/cimagem/p17_art_ducha.htm De certo modo, a provocação do artista iria prenunciar as mais recentes campanhas publicitárias do banco, como a solicitação e o estímulo para que os próprios clientes sejam, "viralmente", produtores, agentes e veiculadores da marca, ao fazerem amadoramente seus próprias peças publicitárias: "O mundo muda. E hoje até nossos clientes estão fazendo comercial na televisão - Itaú, feito para você". Ver Folha de São Paulo, página A9, caderno Poder, em 15 de novembro de 2011. Ou ainda, como chama atenção Cezar Migliorin em seu blog (em 28/10/2011), "Seja você também um outdoor do Itaú", pedalando nas bicicletas da prefeitura da cidade do Rio de Janeiro patrocinadas pelo banco. Ver http://a8000.blogspot.com/2011/10/seja-voce-tambem-um-outdoor-do-itau.html
} 
negociado e atualizado é considerado pelos ideólogos, consultores e empreendedores da era do management o maior dos investimentos - e, talvez, o único possível para tantas milhares de pessoas em cuja existência política está o simples fato de serem "animais viventes" ${ }^{56}$. Como escreve Foucault, em A história da sexualidade, vol. I - a vontade de saber, com a agudeza que lhe é característica: "Por milênios, o homem permaneceu o que era para Aristóteles: um animal vivente e, além disso, capaz de existência política; o homem moderno é um animal em cuja política está em questão a sua vida de ser vivente" (1997:127).

\section{Espectador participador}

De fato, como nos lembra André Brasil, dos shows de realidade aos vídeos pessoais na internet, das redes sociais aos games, dos documentários às experiências de arte contemporânea, "a vida ordinária é convocada, estimulada, provocada a participar e interagir, em uma constante performance de si mesma" (2010:03). Nesse panorama marcado por uma mitologia da autorrealização fundada em valores da ação, em que os biopoderes, como tão bem cartografou Foucault, microfísicos e capilarizados por todo o corpo social, produtivos e não mais repressivos ou punitivos, cada vez mais seduzem, solicitam e convocam nossa ativa colaboração - seja por meio de renovadas estratégias de interação, seja por meio de nossa voluntária observação -, o espectador é tornado um participador, um colaborador, que, por suas próprias mãos e seus próprios dispositivos, fará o jogo se ramificar por todo lugar.

Interessante perceber os deslocamentos pelos quais tem passado a idéia de participação, outrora definida como uma atividade social e republicana. De acordo com o sociólogo Alain Ehrenberg, em $O$ culto da performance - da aventura empreendedora à depressão nervosa, a participação, ao menos aquela que caracterizara a França até os anos 80, marco das análises de Ehrenberg, se fazia em nome da devoção, do sacrifício, seja a uma classe, a uma religião ou a uma nação que, por sua vez, eram os verdadeiros e legítimos atores sociais, como se costuma dizer. A participação pressupunha, portanto,

\footnotetext{
${ }^{56}$ É justamente enquanto "animais viventes", expropriados de existência política e reduzidos a uma performance (comportamental, profissional, social e sexual), que somos tratados como "ser humanoempresa". Essa é a definição do cultuado consultor de gestão e recursos humanos Carlos Hilsdorf, que, em entrevista ao programa "Mundo corporativo", da Rádio CBN (comentada por Cezar Migliorin, em seu blog http://a8000.blogspot.com/) diz: "Se nós aplicássemos as ferramentas de gestão a nós mesmos seríamos um 'ser humano-empresa' melhor. O 'ser humano-empresa' deve perceber onde estão suas forças, fraquezas, riscos e oportunidades".
} 
o apagamento público do indivíduo em nome de um coletivo com o qual ele se identificava e que o transcendia, e, o que é mais interessante, esse apagamento era justamente a prova de seu engajamento (2008:176). Hoje, quando o engajamento social do indivíduo é trocado por sua realização pessoal e por sua visibilidade, a partir de todo tipo de estratégias de gestão e de "empreendedorismo" da própria vida (vida agora identificada a um empreendimento e filiada à comunidade de uma empresa), a participação é reduzida a um "agir sobre si mesmo tendo como representante apenas a si mesmo" (2008: 177).

Nessa era da transparência pela justa concorrência e diante do recuo das instituições estatais de assistência e das formas de autoridade que determinavam previamente os lugares sociais, cada um, de maneira dinâmica, flexível e sob o peso de uma responsabilidade inédita, deve, como um bom jogador, fixar para si mesmo uma posição - por meio da qual passará à ação. Assim, ao expurgar a contemplação e a "passividade", o espectador de antanho é tornado um ator, cujo ponto de vista domina, de agora em diante, a mitologia da autorrealização. Mas, ainda segundo Ehrenberg, "não há nenhuma razão para que o ponto de vista do espectador se enfraqueça, a questão é que o indivíduo comum não deve mais se acomodar a esses devaneios" (2008:11). Exige-se do indivíduo comum, portanto, que aceda à individualidade por meio de um agir e de uma permanente performance que impulsione cada um a se singularizar, tornando-se a si mesmo em meio a uma relação social inteiramente moldada pelo inacabamento.

Se, historicamente, a crítica ao espetáculo feita por Guy Debord (2000) consagrou a perspectiva de que ser espectador é uma coisa ruim, é resignar-se à alienação de uma contemplação destinada a ser sempre passiva - em que olhar significa tanto o oposto de conhecer quanto o oposto de agir -, não foi por outro motivo que o teatro moderno pleiteou também libertar o espectador da passividade de quem, imobilizado em seu lugar, permanecia fascinado pela aparência à sua frente. Ao longo do século XX, diversas tentativas foram feitas nesse sentido, filiadas seja ao teatro épico de Brecht (em que o espectador deveria ficar mais distante) seja ao teatro da crueldade de Artaud (em que o espectador deveria perder toda distância), como sintetiza Jacques Rancière, em seu $O$ espectador emancipado (2008). De acordo com Rancière, todas essas oposições que pressupõem uma lacuna radical entre atividade e inatividade, como olhar/agir, aparência/realidade, passividade/atividade, são muito mais do que oposições lógicas. Elas são, antes, uma "partilha do sensível”, uma distribuição de lugares e de 
capacidades ou incapacidades vinculadas a esses lugares. Em outros termos, essas oposições dicotômicas são, para o filósofo, alegorias da desigualdade.

O que ocorreu, entretanto, foi que o primado da televisão, em sua plasticidade e seu inaudito poder de captura e fagocitação, apropriou-se das vanguardas transformando a conquistada atividade do espectador em "interatividade" e "participação", como se houvesse nesse processo uma conquista, um upgrade de categoria. No caso específico das vanguardas artísticas brasileiras de fins dos anos 60, cabe lembrar que Hélio Oiticica $^{57}$ postulava precursoramente (e, evidentemente, em reação a seu momento histórico particular) outra concepção de arte, ou de "anti-arte", de espectador e de ação criadora realmente libertária, mas que partia do pressuposto de que ser espectador era ser passivo, contemplativo, era ter a mente atrofiada em suas potencialidades imaginativas e o corpo imobilizado em suas capacidades locomotivas. Porém, nessas proposições, desenvolvidas em função dos Penetráveis, Bólides e Parangolés, Oiticica não estava à procura de um novo condicionamento para o novo espectador - chamado por ele, já naquela época, de "participador" -, mas sim da derrubada de todo condicionamento, em favor da disponibilidade, do improviso, da liberdade e de um estado criador.

No entanto, se o cinema, os jogos televisivos, os dispositivos audiovisuais e as novas dramaturgias capturaram, tomando para si, as proposições das vanguardas artísticas, roteirizando e instrumentalizando, em nome de um "apelo realista", a disponibilidade, o processo e a liberdade do improviso, é porque poderíamos dizer, sem leviandade e alguma tragicidade, que as esferas telemidiáticas e as empresas de comunicação foram mais tropicalistas do que o tropicalismo. Fazendo eco ao pensamento de Jean-Louis Comolli, o cinema não é mais o laboratório onde de fato se inventa o novo espectador, "essa construção histórica, relativa, dependente das forças

\footnotetext{
57 "Toda a minha evolução, que chega aqui à formulação do Parangolé, visa a essa incorporação mágica dos elementos da obra como tal, numa vivência total do espectador que agora chamo 'participador'. (...) O 'vestir', sentido maior e total da obra, contrapõe-se ao 'assistir', sentido secundário (...)". OITICICA, Hélio. "Anotações sobre o Parangolé”. In: Aspiro ao grande labirinto. Rio de Janeiro: Rocco, 1986, p.71. E ainda: "A participação do espectador é fundamental aqui [nos Penetráveis, Bólides e Parangolés], é o princípio do que se poderia chamar de 'proposições para a criação', que culmina no que formulei como anti-arte. Não se trata mais de impor um acervo de idéias e estruturas acabadas ao espectador, mas de procurar pela descentralização da arte, pelo deslocamento do que se designa como arte, do campo intelectual racional para o da proposição criativa e vivencial; dar ao homem, ao indivíduo de hoje, a possibilidade de 'experimentar a criação', de descobrir pela participação, esta de diversas ordens, algo que para ele possua significado". OITICICA, Hélio. "Situação da vanguarda". In: Aspiro ao grande labirinto. Rio de Janeiro: Rocco, 1986, p.111
} 
econômicas e dos desafios ideológicos tanto quanto das performances tecnológicas". Hoje, tal tarefa cabe, portanto, às televisões, mais especificamente ao primado dos jogos televisivos, cuja dramaturgia - prima-irmã das gincanas empresariais - alastra-se pelos mais insuspeitos e "artísticos" formatos narrativos.

Ativo, interativo e, sobretudo, participativo, o então outrora espectador ${ }^{58}$ se torna o grande produtor contemporâneo: produz experiências, valor, imagens, formas de vida, gestos performativos e palavras de ordem. Quanto mais crê ser livre para interagir, escolher e decidir, e, do mesmo modo, quanto mais crê ser livre para se desengajar ou desistir, quando assim lhe for conveniente, mais o espectador-participador contemporâneo se coloca disponível aos desígnios de um jogo (o jogo como dramaturgia e forma de organização social) que, como tal, pretende excluir toda distância, perspectiva e exterioridade da imagem - situação em que não haveria mais posicionamento e julgamento de fato. Pois, como nos ensina o perspectivismo (Velloso, 2004), para que se possa ver, avaliar e valorar é preciso, ao tomarmos uma posição, que algo permaneça daí excluído. "Uma perspectiva é não apenas o que limita nosso campo de visão, mas, sobretudo, o que o torna possível: pretender suprimi-la para alcançar as coisas 'em si mesmas' seria um absurdo comparável a querer suprimir os olhos para ver melhor", salienta Silvia Pimenta Velloso (2004:215). Do mesmo modo, para que haja um espectador, é preciso que se assegure e resguarde certa distância. Afinal, se a diferença é a condição mesma de todo enlace, ser um espectador (espectare), enquanto “animal vivente" capaz de existência política, é pôr-se em relação.

No entanto, alguns autores parecem defender uma visão totalizante e equivocadamente "imanentista" do jogo como a própria forma da vida social, esse jogo cujo potencial lúdico e disruptivo, cuja dimensão residual e criadora (e não "criativa"), foram capturados pela lógica da empresa, da guerra e da televisão. “A vida como jogo é uma espécie de aceitação do mundo tal qual é”, postula Michel Maffesoli (2003:78), para quem o trabalho e o jogo, a partir do paradigma da "eterna criança", a criança produtiva, gestora e hiperativa do capitalismo avançado, se unificam sob o nome de “criatividade". Nesse contexto, em que o homo ludens (Huizinga, 2008) fora substituído pelo homem do cálculo, sintetiza André Brasil, "não estamos, então, no domínio da pura

\footnotetext{
${ }^{58}$ Como não poderia deixar de ser mais sintomático, na época de redação da primeira versão deste texto em fins de 2009, circulava na internet o seguinte email do Centro de Inovação e Criatividade da ESPM: "Quem é você? Espectador? Chame como quiser. Pode ser web 2.0, web 3.0 ou webflex. A humanidade vive uma era de ruptura. A era da informação está sendo substituída pela era da participação".
} 
representação, mas da representação tornada performance, da performance tornada jogo e, por fim, do jogo generalizado como estratégia de gestão" (2010:06).

Antes de prosseguirmos, é preciso esclarecer o que entendemos por performance, esse conceito a um só tempo indeterminado e operatório em situações de indeterminação. Inacabado, flexível, processual, interacional, inclusivo e absolutamente permissivo, o conceito de performance, para os Performance Studies, confunde-se com o diagnóstico de nossa própria época, pautada pelo elogio aos valores ligados à ação, à flexibilidade e à adaptação, embora, evidentemente, os Performance Studies não façam tal diagnóstico, sendo estes valores a serem celebrados. Assim, a performance para esses pensadores ligados ao teatro e à antropologia (como Richard Schechner, Ian Maxwell, Victor Turner, entre outros) não se limita às práticas artísticas ou aos ritos sacros, devendo abranger toda a variedade de disciplinas possível e ser generalizável a todo tipo de prática dita performativa, em um "continuum horizontal" sem hierarquia que compreende, além das criações artísticas, manifestações cotidianas, situações profissionais, ocupações esportivas, contextos tecnológicos, relações sexuais e rituais sacros e profanos. Não por acaso, a idéia de jogo, segundo Schechner, encontra-se no coração das teorias da performance, para quem, não se sabe se ingênua, maliciosa ou cinicamente, "o jogo pode subverter os poderes constituídos, como na paródia ou nos carnavais, ou pode ser um jogo cruel, um poder absoluto...” (apud Féral, 2009:58).

De toda forma, é importante perceber que o caráter inacabado da performance é o que garante, de um lado, sua eficiência e pregnância cultural, isto é, a possibilidade de toda sorte de instrumentalização do conceito, e, de outro, sua vitalidade conceitual mesmo. Por sua "natureza" não-substancialista e operando capilarmente nos interstícios entre experiência e representação, vida e cena, a performance, esse conceito então de difícil definição, parece tão mais ardilosa e esquiva quanto mais se tenta defini-la. No entanto, podemos e devemos tentar uma aproximação. Aqui compreendida como elemento operatório das dinâmicas capitalistas e subjetivas em jogo em uma sociedade "flexível", no contexto de um capitalismo "pós-industrial" e "imaterial"59, cujo núcleo da produção econômica é a própria vida, o conhecimento, o imaginário, a comunicação

\footnotetext{
${ }^{59}$ O regime de produção "pós-fordista" ou "pós-industrial" ensejou, segundo diversos autores, um novo modo de agenciamento capitalista, denominado "capitalismo imaterial" ou "cognitivo". Ver: GORZ, André. O imaterial - conhecimento, valor e capital. São Paulo: Annablume, 2005; COCCO, Giuseppe. Capitalismo cognitivo - trabalho, redes e inovação. Rio de Janeiro: DP\&A, 2003; bem como NEGRI, Antonio. e LAZZARATO, Maurízio. Trabalho imaterial. Rio de Janeiro: DP\&A, 2001.
} 
e a informação, a performance atuaria em uma zona indeterminação entre estética, mercado e política, dificilmente diferindo a produção de si dos fluxos capitalistas.

Articulados assim à esfera do audiovisual teleprogramado e ao próprio cinema que de forma nenhuma está apartado de todos esses processos culturais, políticos, sociais -, a indeterminação, o paradoxo e o cinismo amalgamam a própria lógica da face imaterial do capitalismo tardio, pós-industrial e pós-ideológico, em que os poderes, além de promoverem uma coincidência entre a dimensão lúdica, própria ao jogo ${ }^{60}$, e a dimensão do cálculo, própria à biopolítica, não mais mascaram suas prerrogativas e seus efeitos, explicitando-os irônica e reflexivamente. Como nos diz Safatle, comentando a passagem de um capitalismo trágico para um capitalismo cínico:

Ao invés da tragédia de um sistema socioeconômico que a todo momento funcionava através do ocultamento do caráter fetichista de seus processos de determinação de valor (...), teríamos o cinismo de práticas capazes de reduplicar seu próprio sistema de representações, tal como em uma eterna paródia. (2008:92)

A publicidade contemporânea é paradigmática para a compreensão desse fenômeno. A comentada campanha da Dove pela "Real beleza", por exemplo, que, em um vídeo de 2007, nos mostra o processo de construção de uma imagem ideal, bela e asséptica, isto é, de uma imagem publicitária em sua concepção tradicional, é exemplar para compreendermos esse processo em que a própria imagem revela suas condições - e seu poder - de produção e construção. Como se não interessasse o que eles, os publicitários, por exemplo, conseguem fazer com a imagem, mas que tenham o poder para fazê-lo. Desse modo, a "publicidade esclarecida", supostamente autocrítica, e a imagem "reflexiva" parecem apontar para uma virtualidade do próprio poder (Migliorin, 2008), zombando de nossa credulidade.

Se a paulatina indeterminação entre toda sorte de "fronteiras", que, não faz muito tempo, constituíam os alicerces da modernidade (como público e privado, intimidade e visibilidade, pessoa e personagem, experiência e representação, atividade e passividade, para citarmos alguns exemplos), em vez de colocar os sistemas em crise, acaba por ser a base de sua manutenção, é fundamental esclarecer que, no âmbito do cinema, alguns filmes escapam àquilo que é dominante, escovando a contrapelo a eloqüência dessas paradoxais e indeterminadas práticas sociais e culturais. Entretanto,

\footnotetext{
${ }^{60}$ Sobre a dimensão lúdica do jogo, isto é, o jogo como atividade humana simultaneamente cultural e précultural, ver o inventário de HUIZINGA, J. Homo ludens. São Paulo: Perspectiva, 2008.
} 
antes de nos atermos a um caso desse tipo, como o filme Pan-cinema permanente, de Carlos Nader (2008), é preciso partir do solo em que esses vetores são sintomaticamente - porém não desprovidos de inquietude - colocados em jogo, caso de Filmefobia, de Kiko Goifman (2009).

\section{Filmefobia:}

\section{Porque indeterminar é não alterar}

Em seu primeiro longa-metragem, 33 (2003), o diretor Kiko Goifman gerou um intenso debate no campo do documentário ao realizar uma espécie de documentário ficcional a partir da construção de um filme-dispositivo narrado na primeira pessoa do singular: Kiko, diretor-personagem, com então 33 anos, teria 33 dias para encontrar, sem pesquisa prévia e com a ajuda de detetives, sua mãe biológica. "Sempre gostei de dizer que sou filho adotivo. As pessoas se sentem escolhidas por ouvirem a confissão de um segredo", diz Kiko, em voz-off, dando início, já provocativamente, à sua narrativa. Filiada aos códigos do cinema noir e da literatura policial, o diretor só filma durante as noites e em preto-e-branco, momento em que reconstrói, com imagens da cidade vazia e música atmosférica, o método empregado durante o dia. Por meio desse dispositivo, o filme incorpora de fato seu próprio processo, estabelecendo uma interessante tensão entre controle e acaso, entre evidência e desconfiança. "Me tornei um desconfiado compulsivo", ele nos diz logo na primeira seqüência, antecipando de certo modo um movimento de suspeita ${ }^{61}$ em relação às imagens "documentais" ao qual alguns filmes brasileiros iriam a partir de então se afinar - caso notório de Jogo de cena (Eduardo Coutinho, 2007) e Santiago (João Moreira Salles, 2007).

Para dar conta de sua atitude cronicamente desconfiada, o diretor Kiko Goifman constrói uma espécie de jogo marcado pelo distanciamento e disposição ao confronto, de um lado, e pela indistinção entre experiência pessoal e encenação para a câmera, de outro. Tal disposição ao confronto (seja com os detetives, seja com a própria família) e "atitude humorística" ou "de jogo" (assim denominada e altamente valorizada na época pelo crítico Jean-Claude Bernardet) eram, em 33, capazes de sustentar uma interessante tensão com as contingências de uma realidade construída, porém não redutível à mera

\footnotetext{
${ }^{61}$ Verbalizando sua suspeita, nos diz o narrador de Santiago (João Moreira Salles, 2007): "Hoje, treze anos depois, é difícil saber até onde íamos em busca do quadro perfeito, da fala perfeita. O que fica claro é que tudo deve ser visto com uma certa desconfiança."
} 
paródia ou pastiche. E assim, o que em 33 era da ordem de uma verdade ou de uma força expressiva do processo, ainda que na chave dos códigos da ficção noir - o que provia o filme de ainda mais interesse e expressividade -, em Filmefobia, seu segundo longa-metragem, espécie de ficção documentária, fora transformado em simulação desvitalizada e falsamente autoconsciente.

Construído na instabilidade e na indeterminação entre realidade e ficção, Filmefobia se apresenta como um making off (fictício) de um documentário (também fictício) a que estaríamos assistindo, em que fóbicos encaram suas fobias, atores incorporam fobias alheias e atores fóbicos, em situações explicitamente simuladas ou não, encenam os seus próprios pavores - jogo que não deixa de emular o método proposto por Jogo de cena, de Coutinho. Alternando performances "fóbicas" explicitamente encenadas e estetizadas com metas-discussões de "bastidor", isto é, alternando a cena e o processo (também construído como cena), Filmefobia é assim uma espécie de filme-jogo-ensaio, de filme dentro do filme, em que as imagens vão se desdobrando a partir de autoficções. O personagem Kiko, vivido pelo diretor Kiko Goifman, é tanto o diretor do making off quanto uma espécie de "observador participante" do experimento concebido pelo personagem Jean-Claude. O personagem Jean-Claude, protagonizado pelo crítico Jean-Claude Bernardet (ganhador, por sua autoficção, do prêmio de Melhor Ator no Festival de Brasília de 2009), é então o diretor do filme que, quiçá, será feito.

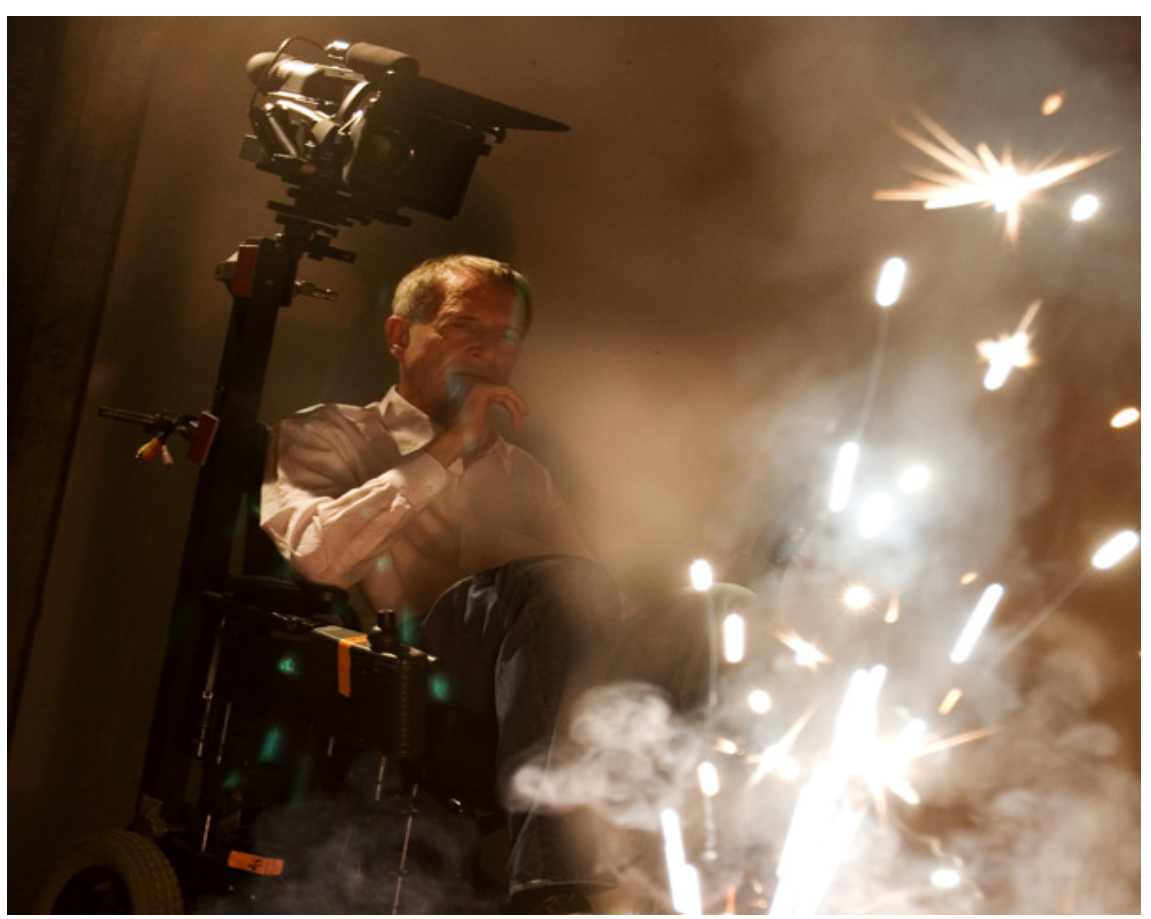


Jean-Claude é a mente organizadora, o porta-voz do saber, e é ele quem postula as teses constitutivas do experimento, que, uma a uma, vão sendo dissolvidas. Em uma falsa busca por uma imagem falsamente verdadeira, Filmefobia fragiliza e deslegitima, reflexivamente, suas próprias (falsas) prerrogativas, sem, com isso, inviabilizá-las ou destituí-las de validade. Como veremos, e como já vimos por meio da lógica do cinismo, essa dinâmica de permanente anulação daquilo que o próprio filme enuncia como máxima verdade, em que proposições contrárias se sustentam simultaneamente, em vez de colocar o filme em crise, acaba por ser a base de sua sustentação.

Articulado a partir da indistinção entre diversas instâncias narrativas - o que é o filme propriamente dito, o que são as imagens do making off realizado pelo personagem Kiko, o que são as imagens do documentário concebido, e por vezes filmado, pelo personagem Jean-Claude (que em alguns momentos aparece portanto uma câmera) -, em Filmefobia não há centro nem unidade de questões. Sua dinâmica excêntrica ou sem centro visa produzir, permanentemente, uma série de instabilidades, em que a enunciação do filme propriamente, de difícil reconhecimento, freqüentemente delega seu ponto de vista, bem como sua responsabilidade, a essas duas outras instâncias, os personagens Kiko e Jean-Claude. Na maior parte do tempo, porém, a enunciação do filme, ainda que instável, vai aderindo à perspectiva do filme (o tal documentário) que está sendo realizado pelo personagem Jean-Claude, sem propor qualquer diálogo crítico que se articule na relação entre som e imagem. Advém daí um caráter meramente ilustrativo das imagens, bem como um caráter eminentemente discursivo do filme.

Em Filmefobia, as imagens não têm qualquer autonomia, sendo excessivamente dependentes das teses, ou das falsas teses, que o filme vai inseminando e anulando. "A única imagem verdadeira é a de um fóbico diante de sua fobia”, postula, logo no início de Filmefobia, o personagem Jean-Claude. Ao que o filme, por meio dos experimentos que se sucederão, isto é, da roteirização e da instrumentalização da experiência a partir das performances filmadas, autênticas ou encenadas, buscará essa imagem verdadeira. Um pouco mais tarde, Jean-Claude adverte: "O problema da verdade não se coloca, o que se coloca é o problema do processo". E então explicita seu jogo: "A esperança é que a pessoa se descontrole, que sua reação extravase a sua possibilidade de controle sobre si mesma. É exatamente aí que se insere a imagem que eu procuro, porque é tudo feito para a imagem".

Se tudo é feito para a imagem, toda verdade é efeito. Até aí, nenhuma novidade. As conquistas estéticas e conceituais em direção à verdade do cinema, e não no cinema, 
implementadas pelo cinéma-vérité francês já nos anos 60, por meio de Jean Rouch e Edgar Morin, alcançavam, já naquela época, uma potência estética sem precedentes. Quase cinquenta anos mais tarde, o personagem Jean-Claude "descobre" a verdade $d a$ imagem menos por ingenuidade do que por cinismo. Não é o filme que revê seus procedimentos, é o personagem que joga com o filme. Ao contrário do que pleiteia Jean-Claude, o personagem, em Filmefobia não há experiência nem processo. Tudo é jogo, um jogo que, por meio de uma identificação irônica, zomba não daquilo que faz (carregar mensagens), que promove (construir imagens) e que põe em cena, mas do poder que tem para fazê-lo. Protegido pela auto-ironia, o jogo em Filmefobia recusa a experiência em detrimento do fetiche da performance e do processo.

Nesse sentido, se a performance em Filmefobia é completamente estabilizada e dada por acabada (ao contrário de seu inacabamento constitutivo), se a performance nesse caso simplesmente duplica o mundo filmado na chave da verdade ou da mentira, isto é, na chave da representação, o processo, por seu turno, igualmente roteirizado, programado e deliberadamente encenado não nos garante nenhum tipo de clarificação dos mecanismos de produção de sentido da obra. Ao contrário, hoje, tal revelação ou simulação reverte-se mesmo na própria condição de fetichização das obras. Como argumenta Safatle no capítulo "O esgotamento da forma crítica como valor estético" de seu livro Cinismo e falência da crítica, o valor estético na modernidade, vinculado às estratégias de desvelamento dos mecanismos de produção de sentido das obras, isto é, vinculado à possibilidade das obras servirem como palco de seus próprios processos de construção - dos quais o cinema nos deu, e continua a nos dar, belos exemplos ${ }^{62}-$, tende a ser hoje transformado em glamour, disponibilizado pelos âmbitos mais fetichizados da cultura, como a moda e a pornografia.

Lembremos da grife Ellus, que, em um desfile em 2010, levou os bastidores para a passarela, "retirando", segundo uma nota na imprensa, o "glamour das modelos" 63. Mas o glamour, sabe bem a Ellus, está na própria captura (e consequente esvaziamento) do potencial disruptivo que um dia pertencera à esfera das vanguardas. Já no âmbito da pornografia, uma neo-pornografia "socialmente responsável", digamos assim, a revista

\footnotetext{
${ }^{62}$ De Godard a Kiarostami, passando por Fellini, Makhmalbaf, Miguel Gomes, Eduardo Coutinho e Andrea Tonacci, para citar apenas alguns exemplos, o cinema moderno e contemporâneo continua a fazer do processo um tema/forma de investigação altamente potente, em filmes cuja escritura é inseparável da experiência compartilhada em seu processo de produção, em filmes cuja escritura não apenas "captura" o mundo e o outro filmado como os transformam e alteram.

${ }^{63}$ Citado por Cezar Migliorin em seu blog (http://a8000.blogspot.com/), a partir de nota no jornal O Globo Online, em 10/06/10.
} 
TPM de abril de 2010 trazia em suas páginas a matéria "Nudez sem castigo"64, acompanhada do seguinte subtítulo: "Despidas de roupa, vergonha e Photoshop, elas toparam ser fotografadas por um desconhecido", em mais uma dessas iniciativas na qual gestão libidinal, capitalização da beleza "natural" e "autêntica" de mulheres "comuns" (tal como aquela campanha da Dove pela "real beleza") e "responsabilidade social" estão reunidas e indeterminadas. Sem falar em exemplos do próprio cinema, sobretudo os filiados ao gênero do terror que se constroem como falsos documentários ${ }^{65}$, para os quais a simulação do processo como estrutura narrativa (a partir de códigos estéticos próprios às imagens amadoras, supostamente autênticas) garante a eficácia do pavor.

Nesse achatamento biopolítico da experiência, a vida, reduzida à predominância do corpo e à performance do medo - temas tão em voga na arte contemporânea -, é movida a reações a estímulos físicos e psicológicos. Em Filmefobia, se os corpos não agem, apenas reagem, a imagem, por sua vez, se afigura como efeito de um constrangimento, ainda que um constrangimento voluntário e consentido. Tal como ocorre nas dinâmicas dos reality shows, em Filmefobia, atores amadores, atores profissionais ou atores profissionais que simulam serem amadores se submetem a constrangimentos variados a fim de se emancipar (de suas fobias) pela imagem. Esse constrangimento voluntário, consentido e supostamente terapêutico fica evidente na sequência do suposto conflito entre Jean-Claude e um fóbico de palhaço, em que JeanClaude exige autoritariamente uma reação expansiva, exteriorizada e performática de seu "intérprete" (que reagira discretamente às macabras risadas do palhaço), afirmando ser possível simular uma reação a uma fobia e essa reação, enquanto imagem, ser ainda mais verdadeira. Como já dissera um dia Serge Daney (2007:229), a respeito do que ele denominava como "terceiro estado da imagem" - momento em que o cinema não mais precisaria denunciar sua ilusão constitutiva, pois ao fundo de cada imagem não haveria uma verdade, senão outra imagem -, "Nada mais acontece aos humanos, pois é na imagem que tudo acontece" (Cinejournal, Cahiers du Cinéma, 1998; apud Lins; Gervaiseau; França, 1999).

\footnotetext{
${ }^{64}$ Disponível em: http://revistatpm.uol.com.br/revista/97/reportagens/nudez-sem-castigo.html. Além da matéria em questão, a revista TRIP, versão masculina da TPM, tem o hábito de todo final de ano trazer um ensaio sensual com suas funcionárias, "emancipando-as", por suas belezas "naturais" e "autênticas", do homogêneo mundo do trabalho. Disponível em: http://revistatrip.uol.com.br/revista/184/tripgirls/funcionarias-do-ano.html

65 Os falsos documentários ou "mockumentários" não só travessam a história do cinema como praticamente constituem um subgênero do terror, como vemos no paradigmático A bruxa de Blair (Daniel Myrick, Eduardo Sánchez, EUA, 1999) e seus derivados dos anos 2000 (REC, Cloverfield, Atividade Paranormal), onde se inclui o brasileiro Os desaparecidos (David Schurmann, 2011).
} 


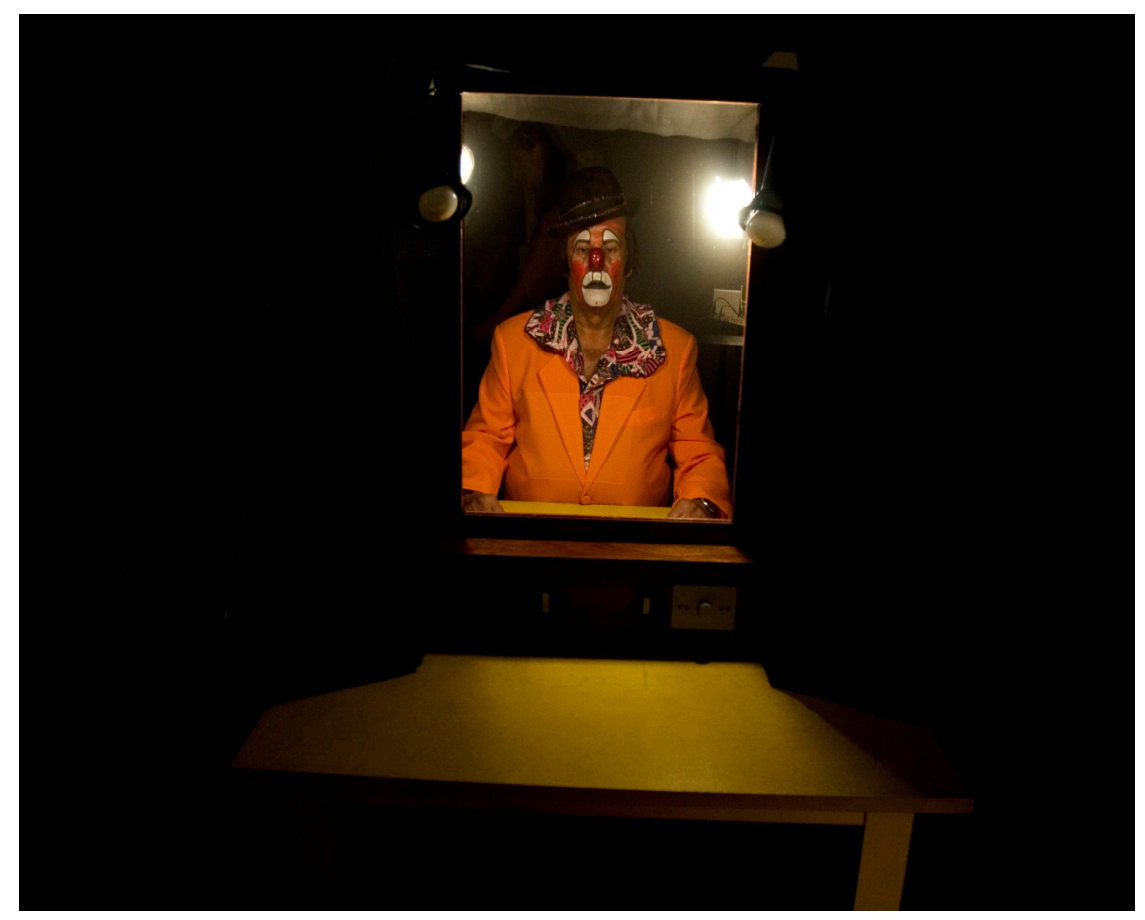

No entanto, não há conflito em Filmefobia, nem no âmbito dos próprios experimentos, completamente desprovidos de uma tensão intrínseca, nem no âmbito das relações propostas pelo filme. A imagem em Filmefobia é puro diagnóstico, consenso, confirmação, consentimento, embora busque, ao menos enquanto discurso, o acesso a um tipo de verdade proporcionada pela reação física ao medo: seja a verdade na imagem, seja a verdade da imagem. Em Filmefobia, o conflito é então substituído por paradoxais situações encenadas que visam produzir e agenciar um efeito de indeterminação, mas que, de fato, são tão excessivamente programadas e roteirizadas que nada ali parece poder irromper de inaudito. O problema político que advém dessas escolhas é o fato de que as performances dos atores, profissionais ou amadores, ao encenarem "o real como artifício e o artifício como real", passando de uma situação a outra, parecem estar finalmente liberadas do "enfrentamento das contradições inerentes a uma e outra" (Brasil, 2010:08). Tal estratégia nos remete ao conceito de "paixão pelo Real”, desenvolvido pelo filósofo Slavoj Zizek:

O problema com a "paixão pelo Real" do século XX não é o fato de ela ser uma paixão pelo Real, mas sim o fato de ser uma paixão falsa em que a implacável busca pelo Real que há por detrás das aparências é o estratagema definitivo para se evitar o confronto com ele. (2003:39)

Se a "paixão pelo Real" é uma paixão "falsa”, em função do caráter selvagem, traumático ou excessivo do Real, cuja impossibilidade de integrá-lo ao que tomamos 
por realidade nos faz senti-lo como um efeito, como um semblante ficcional, é porque a "paixão pelo Real" recusa aquilo mesmo que deseja, sem com isso perder sua validade ou fragilizar-se enquanto enunciado. Retomando o raciocínio de Vladimir Safatle, talvez “a paixão pelo Real” possa ser também pensada como uma "estrutura paradoxal da racionalidade cínica", estrutura normativa dual que impede qualquer fixação ou determinação de sentido. Em dado momento de Filmefobia, há um psicanalista que diz que a fobia é o medo da liberdade, o medo do elemento aberto da liberdade - donde se conclui que a fobia é o medo da indeterminação. E é justamente para evitar esse medo, para evitar o confronto com ele, que o cinismo, enquanto disposição de conduta apta a estabilizar e interagir em situações de anomia, pode operar como um estratagema capaz de transformar o "sofrimento da indeterminação normativa em motivo de gozo" (Safatle, 2008:16).

Nesse cinema-jogo que é Filmefobia, assentado sobre paradoxais estruturas normativas, não se trata mais, como diria Jean-Louis Commoli, de "crer sem deixar de duvidar ou duvidar sem deixar de crer" (2008:11). O problema da crença, outrora motor do cinema, já não se apresenta para o novo estatuto de espectador - reivindicado por Filmefobia e por toda sorte de jogos audiovisuais -, tornado agora, como vimos, um colaborador ativo e reflexivo, permanentemente solicitado a pôr o dispositivo para funcionar. Neste ponto, a reflexividade, de tradicional forma crítica (se pensarmos historicamente na relação entre anti-ilusionismo e crítica às ideologias), tem se tornado uma forma cínica no contexto de nossas sociedades pós-ideológicas, em que o outrora potencial disruptivo da arte moderna fora transformado em coeficiente de autenticidade das obras, legitimadas em função da exposição de seu processo.

Se, para ser espectador é preciso aceitar crer no que vemos, e, para sê-lo ainda mais, seria preciso começar a duvidar, sem deixar de crer, como defende Comolli, o espectador contemporâneo, crendo cinicamente que não crê mais, estaria em posição privilegiada para gozar das angústias da crença (e da dúvida) dos outros. Não é outra coisa o que faz o personagem Jean-Claude em Filmefobia. Espectador e participador (ou "observador participante") dos experimentos que coloca em cena, senhor e personagem de seu próprio jogo, a ironia reflexiva de Jean-Claude permite que ele goze do simultâneo engajamento e desengajamento de seus personagens, assim como de seu próprio sistema de representação, perpetuamente reduplicado como em uma eterna paródia. "Silêncio!", nos diz Jean-Claude na sequiência final (e calcada no processo) do filme, repetindo diversas vezes as mesmas palavras em um estúdio de gravação e edição 
de som, até o completo esvaziamento de sentido das mesmas, até elas se tornarem mera forma vazia: forma pronta a se adequar a qualquer transitório e oportuno sentido. E quem quiser "interpretá-lo" ou "criticá-lo" será nada mais que um tolo - aquele que não sabe gozar estupidamente ${ }^{66}$ das angústias da crença, da dúvida e do medo dos outros.

Intimado pelo espetáculo a dele tomar parte, consentindo e não consentindo, se engajando e se desengajando, sendo cúmplice e adversário ao mesmo tempo, o espectador participador contemporâneo (tal como Jean-Claude em Filmefobia), autoconsciente, reflexivo e acoplado às engrenagens dos dispositivos, é, como não poderia deixar de ser, um típico cínico. Não seria exagero, portanto, identificar que esse cinema auto-reflexivo e colaborativo - e sintomaticamente Filmefobia fez uso de diversas estratégias colaborativas durante seu processo de preparação e divulgação, do tipo "compartilhe a sua fobia conosco" - pressupõe um espectador também cínico, informado desde sempre de que, como diria aquele juiz de futebol, "a regra é clara": o cinema, a publicidade, a moda e até a pornografia, assim como o sistema capitalista, expõem suas premissas, explicitam seus funcionamentos, revelam seus domínios e seus constrangimentos, rindo reflexivamente de suas próprias capacidades "autocríticas"67.

Ironia das ironias: não sabemos a que exatamente somos levados a servir e a colaborar, mas certamente cremos - sim, nisso pelo menos ainda cremos - que na "participação" e na "interação", proporcionada pelos dispositivos comunicacionais e informacionais contemporâneos, está nossa liberação. (Ainda que haja gente com fobia de celular, como encena uma das cobaias de Filmefobia. Mas ficou faltando a fobia de cinema.)

\footnotetext{
${ }^{66}$ Sendo o cinismo a forma da racionalidade social em uma sociedade flexível, dotada de uma ideologia reflexiva (capaz de incorporar as críticas a ela endereçadas sem que essa incorporação resulte em fragilização dos enunciados ideológicos), a análise da publicidade contemporânea (supostamente crítica, "esperta" e auto-reflexiva) se faz premente, tal como a recente campanha da grife Diesel, "Be stupid". A esse respeito, ver BRASIL, André; MIGLIORIN, Cezar. "Be stupid: a Diesel e o biopoder". In: Ciberlegenda. Edição 22, $1^{\circ}$ sem. 2010. Disponível em: http://www.proppi.uff.br/ciberlegenda/be-stupid ${ }^{67}$ Como diz Safatle: "A impotência da crítica seria resultado da capacidade do capitalismo - de uma certa forma - realizar cinicamente a crítica" (2008, p.92).
} 


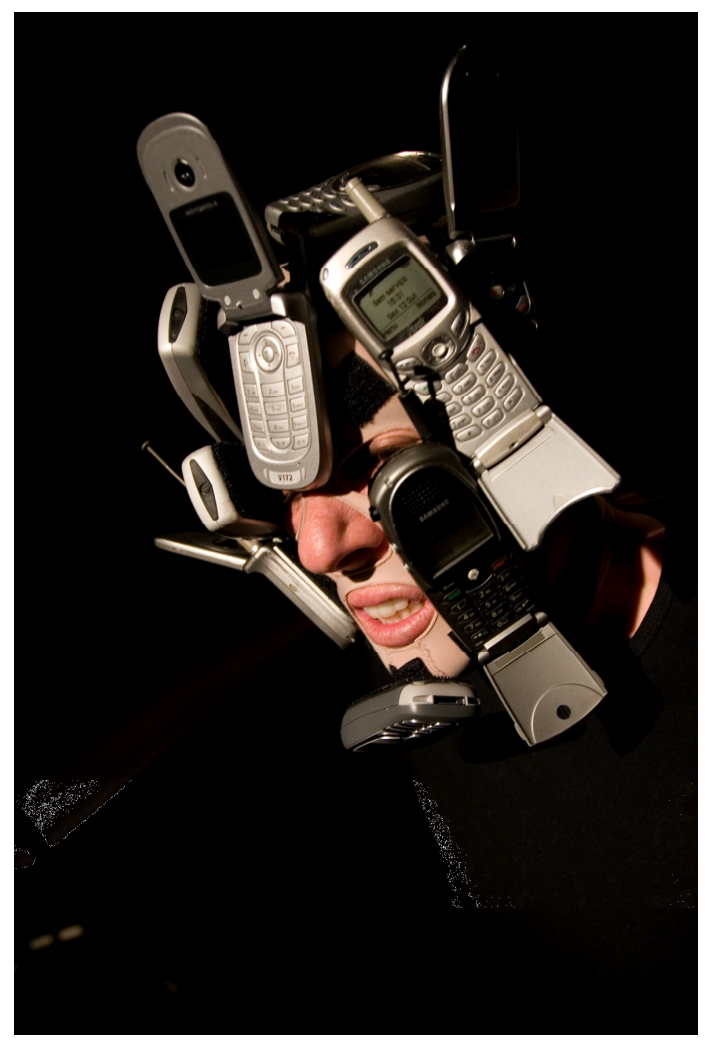

\section{Pan-cinema permanente:}

\section{Porque alterar é determinar a mudança}

Realizados em um momento histórico marcado por diversas figuras da indeterminação, operantes nos (des)limites dos campos artístico e político, da ficção e do documentário, e cujas conseqüências já podemos vislumbrar, tanto Filmefobia quanto Pan-cinema permanente - em diálogo com diversos outros filmes a eles contemporâneos - cristalizam, por meio de suas próprias formas, esse momento em que vive-se o real como artifício e o artifício como real (Brasil, 2010). Nesse sentido, se Filmefobia encena ser um filme sobre o processo de registro do filme a que estamos assistindo, simulando a busca tanto por uma imagem verdadeira quanto por uma verdade indeterminada, Pan-cinema permanente parte de uma busca determinada, quase romântica, pela verdade da imagem, uma imagem que teria de ser não-performática. No entanto, ao investir nas performances, nas autoficções e nas sedutoras indeterminações do poeta Waly Salomão, esse personagem a um só tempo esquivo e excessivo, exuberante e desconcertante, Pan-cinema permanente inviabiliza, de saída, seu projeto, explorando a radical opacidade que se instala entre o poeta, a câmera e o mundo. 
Nessa "exitosa busca sem sucesso" (Eduardo, 2008), reflexiva e afetiva, todo o filme é estruturado por uma espécie de fagocitação libinal entre as imagens: telas dentro de telas, campainhas de teatro, telas pretas, inscrições de palavras nas imagens, performances para a câmera. A partir de uma série de mediações, camadas e superposições, como se a imagem a que assistíssemos fosse uma imagem da imagem, isto é, como se assistíssemos à imagem filmada da imagem originalmente captada, Pancinema permanente adere à perspectiva barroca e mascarada de seu personagem ("Mascarado eu avanço, eu avanço mascarado", declama Waly Salomão), assim como à possibilidade de, em sendo toda experiência mediada, se produzir experiências a partir tanto da mediação quanto da alteração da cena e do mundo - ao contrário, aliás, de Filmefobia, em que não há experiência nem alteração possível.

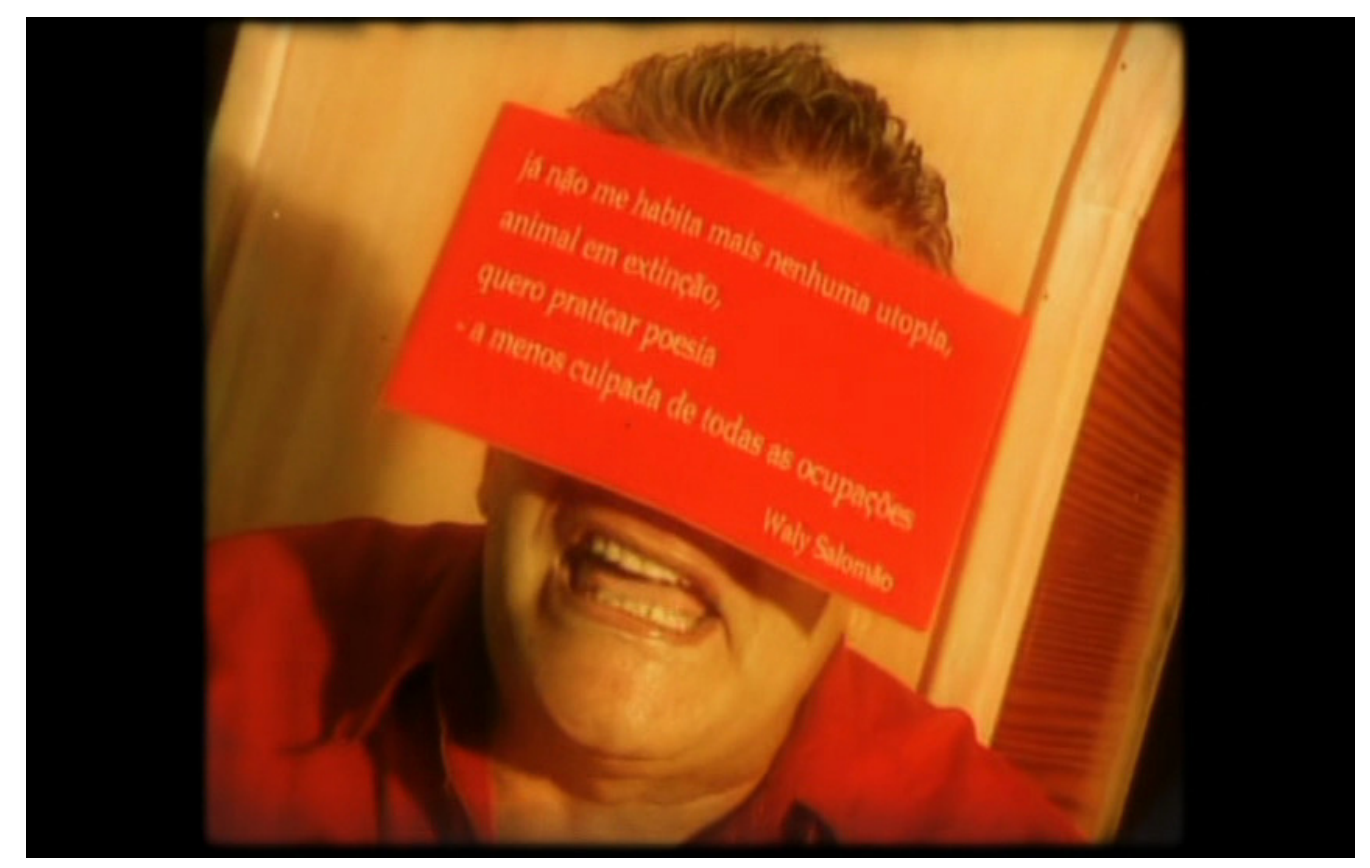

Construído a partir de uma relação de amizade entre cineasta e personagem, relação essa também mediada pela imagem - o diretor Carlos Nader filmara Waly Salomão por mais de dezesseis anos -, Pan-cinema permanente, por meio de "vivazes e contingentes registros descontínuos" (Mesquita, 2010), faz convergir a vida e o vídeo, o espontâneo e o construído, a centrifugacidade do personagem e a moldura da imagem, o movimento permanente e a fixação de sentidos, sem nunca reduzir ou domesticar a figura e a fulguração de Waly Salomão. Personagem excêntrico e relacional por excelência, como que vestido e travestido por um permanente Parangolé, Waly Salomão resiste a todo centro, a toda estabilidade e a toda convenção. 
Para Waly, viver não é natural, viver não é vivível, pois que se faz necessário criar mediações, ilusões, intervir e intensificar a vida através da imagem, por meio do filme. Pois que se faz necessário calçar a imagem, andar sobre ela, imprimir na opaca tela-sola as pegadas da vida. Não é por outro motivo que o poema a nomear o filme, recitado pela voz de Antonio Cícero após a primeira sequiência de abertura (espécie de prólogo do espetáculo a que iremos assistir), justapõe, no plano da narração, a tela à sola de um sapato, enquanto justapõe, no plano da visualidade, a imagem ao chão de asfalto, por onde caminham os pés de Nader. Por meio dessa construção, Pan-cinema permanente, o filme, não fala sobre aquilo que é, mas faz ser, performativamente, aquilo que diz: a primeira imagem que o filme então nos mostra após o prólogo, opaca e material, residual como a fuligem do asfalto, é capaz, por meio de uma fusão, de transformar o chão em um céu negro, de transformar o chão em uma constelação.

Ensaiando ser mais do que um ensaio sobre o cinema, mas um ensaio sobre a mediação, construído a partir de um "anti-discurso da transparência" (como proclama o próprio Waly) e da recusa ao primado do naturalismo documental, tanto o filme quanto seu personagem retomam o regime do artifício, caro ao paradigma do "homem como ator" do século XVIII (Sennett, 2002), e, por meio da teatralização barroca, dão início à desnaturalização - e ao estranhamento - do mundo. Se para Waly Salomão, assim como para os poetas, dramaturgos e artífices do Barroco (cujo sentido literal é "acumulação"), a vida é feita de sonhos, ilusão, sedução, cegamento e auto-engano, é porque a própria fatura fílmica de Pan-cinema é capaz de construir, com Waly e para Waly, por meio do acúmulo e dos artifícios, o mundo como teatro.

Nesse pan cinema $^{68}$ que bem poderia ser uma opera mundi, conceito, aliás, tão caro ao Barroco, o teatro recobre todo o mundo, seja o mundo político, seja o mundo metafísico - e aqui lembremos que até a morte e o paraíso são encenados por Waly. Com isso, não significa dizer que se trata de um simulacro ou de uma falsificação, mas da crença de que, no âmbito das formas postas em cena pelo filme, nada existe aquém e além da encenação. Nesse sentido, é sempre válido ressaltar que o regime performativo do artifício estabelecido por Pan-cinema não se inscreve em uma lógica do mascaramento como falsificação ou ocultação de uma verdade que existiria por trás da máscara, como uma realidade última. Fora nossa tradição filosófica que associou os

${ }^{68}$ É curioso como tanto em Filmefobia como em Pan-cinema permanente, o cinema encontra-se explicitado, de saída, em seus títulos, embora essa dimensão reflexiva tome, em cada uma das obras, sentidos antagônicos. 
temas da máscara e do teatro, da poesia e da retórica, da pintura e da maquiagem, ao campo do falso, do fingimento e à lógica da imitação, mantendo inabalada a crença em identidades previamente fixadas (Ferraz, 2002).

Face a tais crenças, a performance em Pan-cinema, distante da racionalidade instrumental do cálculo, é o gesto que permite que o espaço cênico possa ser, a um só tempo, liberado dos tradicionais poderes e modulado pelas instáveis e singulares relações, que se dão única e exclusivamente na cena. Repondo assim o lúdico e a ociosidade no lugar do "jogo calculado", a relação e a amizade no lugar da "interatividade" e a teatralização do encontro no lugar da "rentabilidade cênica", Pancinema permanente pode ser visto como um manifesto estético e político em favor da opacidade e da vigorosa suspeita de que inexistiria uma realidade última e verdadeira ao fundo de toda imagem - ao contrário do que pregam os saberes e poderes dominantes empenhados em fazer convergir os âmbitos do visível, do real e do verdadeiro, reduzindo muitas vezes as imagens, os $\operatorname{corpos}^{69} \mathrm{e}$ as identidades a feixes de infinitesimais informações digitais. Como já escrevera Giorgio Agamben (2002:106), se para o homem a aparência constitui um problema político e estético é porque ela tornara-se a arena de uma luta pela verdade.

Assim, ainda que a voz do diretor Carlos Nader, enquanto enunciado, busque captar um momento relaxado e não-performático de Waly Salomão, como sabemos pelo diálogo que se dá entre as vozes de Nader e Antonio Cícero, a instância enunciativa de Pan-cinema permanente já parte da premissa, desde a sequiência de abertura, de que tal busca é impossível, inviável. Esquivando-se de qualquer acesso a uma experiência "em si mesma”, não-mediada e não-perspectivada, nesta seqüência inicial, espécie de prólogo, o filme funde o que seria o enquadramento de um aparelho de TV (um aparelho escolhido por um passante qualquer em meio a dezenas de outros vendidos em alguma loja de calçada) com o enquadramento da própria imagem do programa da TV síria em que Waly dá uma entrevista. Esta, transcrita para o formato da tela de cinema, adquire uma moldura, uma primeira mediação material incontornável, que será então sucedida por muitas outras, em variadas formas.

\footnotetext{
${ }^{69}$ Em seu vídeo Concepção (2001), Carlos Nader se utiliza de imagens de uma endoscopia filmada (a sua própria), em uma apropriação das imagens médicas que, mais tarde, se tornaria freqüente na arte contemporânea. O interessante no gesto de Nader, que impede o filme de ser visto como mero sintoma, é o fato de que, como escreveu Antônio Cícero em sua coluna na Folha de São Paulo (Ilustrada, 04/04/2009), quanto mais nos entranhamos nas entranhas de Nader mais nos distanciamos dele, que mais estranho nos parece. A endoscopia transformaria assim o interior em exterior, a interioridade orgânica em física exterioridade, as entranhas em estranhamento.
} 


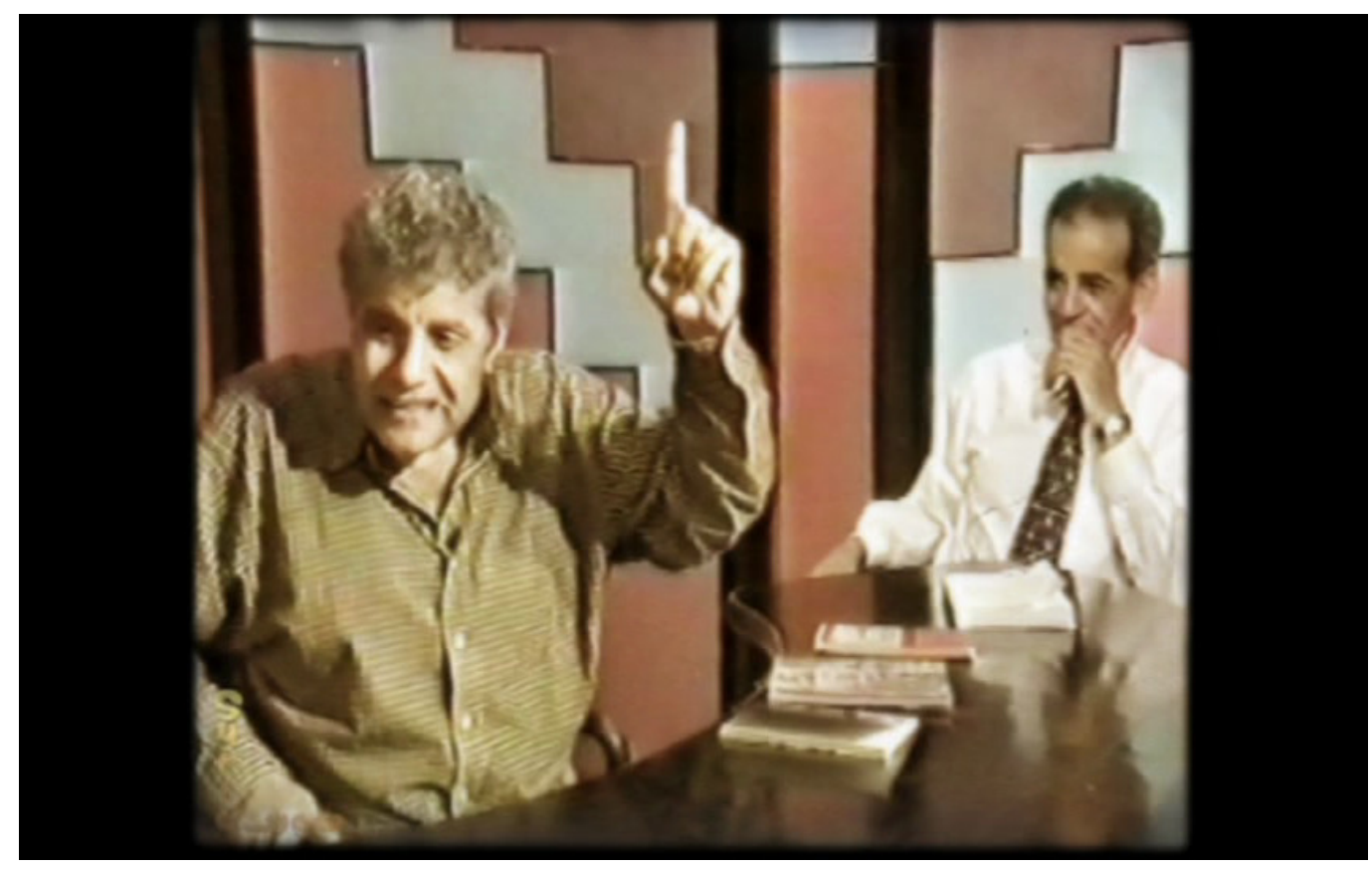

Desse modo, a busca por um momento autêntico, relaxado e não-performático de Waly Salomão seria então uma premissa apenas da voz do diretor enquanto enunciado, mas não do filme como enunciação - paradoxal tensão interna que, ao final, ultrapassará qualquer simples elogio à indeterminação. Nesse sentido, enquanto Filmefobia se empenha em indeterminar, buscando agenciar os efeitos da inicial clivagem entre autenticidade e encenação e sua posterior dissolução, Pan-cinema permanente parte de uma indeterminação já-dada, de uma indistinção entre vida e teatro mobilizada pela presença cênica e performática de Waly Salomão, mas a ultrapassa por meio de suas opções e proposições estéticas.

Fazendo de sua mise-en-scène uma mise-en-abîme, isto é, de um pôr em cena como pôr em abismo, Pan-cinema permanente engendra um regime de "abismos da suspeita" (Velloso, 2003), para o qual não basta duvidar ceticamente, como ocorre com a desconfiança que recai sobre as performances de Filmefobia, já que a dúvida cética exigiria um ponto estável a partir do qual se poderia duvidar. Antes, em Pan-cinema permanente, a relação que o filme estabelece com seu personagem e que nós estabelecemos com o filme é de suspeição, e não de dúvida. Isto porque aqui a performance não se realiza no domínio da representação ou na chave da verdade e da falsidade, como em Filmefobia, mas no domínio do perspectivismo, para o qual performar é menos encenar, fantasiar ou mascarar um corpo do que produzi-lo, reinventá-lo (Brasil, 2011:10). Se em Pan-cinema permanente, assim como em Jogo de 
cena, de Eduardo Coutinho, a fala é um ato e a linguagem instaura o mundo de que se fala, é porque em ambos os filmes a palavra incorporada é o núcleo da cena.

Ultrapassando as posições dicotômicas engendradas pelos pares que a tradição socrático-platônica nos relegou, como essência/aparência, profundidade/superfície, identidade/alteridade, verdade/ficção, Pan-cinema inverte, perspectivamente, o próprio sentido de nossa gramática: não é Waly, sujeito supostamente estável e biografável, que cria suas autoficções e suas perspectivas, são as perspectivas do filme sobre Waly e de Waly em relação ao filme que o criam como sujeito. Isto porque o sujeito só é sujeito quando é capaz de experimentar, em si mesmo, algo que o ultrapassa, algo que o faz nunca ser totalmente idêntico a si mesmo (Safatle, 2009:79). Nesse caso, a estabilidade, bem como a capacidade de representação de todo sujeito que, supostamente, habita um ponto fixo e que é dado como origem de todas as coisas, é radicalmente alterada em favor da instabilidade, dos afetos, das performances e de seus efeitos.

Neste ponto, ainda que a montagem também trabalhe em um horizonte de construção biográfica, cronológica, fixando alguns sentidos e tecendo o "movimento propriamente biográfico, que sintetiza a experiência", segundo Cláudia Mesquita (2010), a dinâmica dos encontros, a exuberância das relações, os modos de costura das passagens entre um fragmento e outro, parecem tensionar essa dimensão biográfica, como se a cronologia de uma biografia fosse mais uma das ficções possíveis para uma vida, fosse mais uma das "ilusões essenciais", como diz a certa altura Waly, das quais não poderíamos prescindir. Por isso o filme, assim comprometido com a vida, também não poderia prescindir de uma dimensão propriamente ou impropriamente biográfica, que de forma nenhuma tiraniza ou subjuga aquele excedente de vida que, ao sempre escapar, não se alcança. 


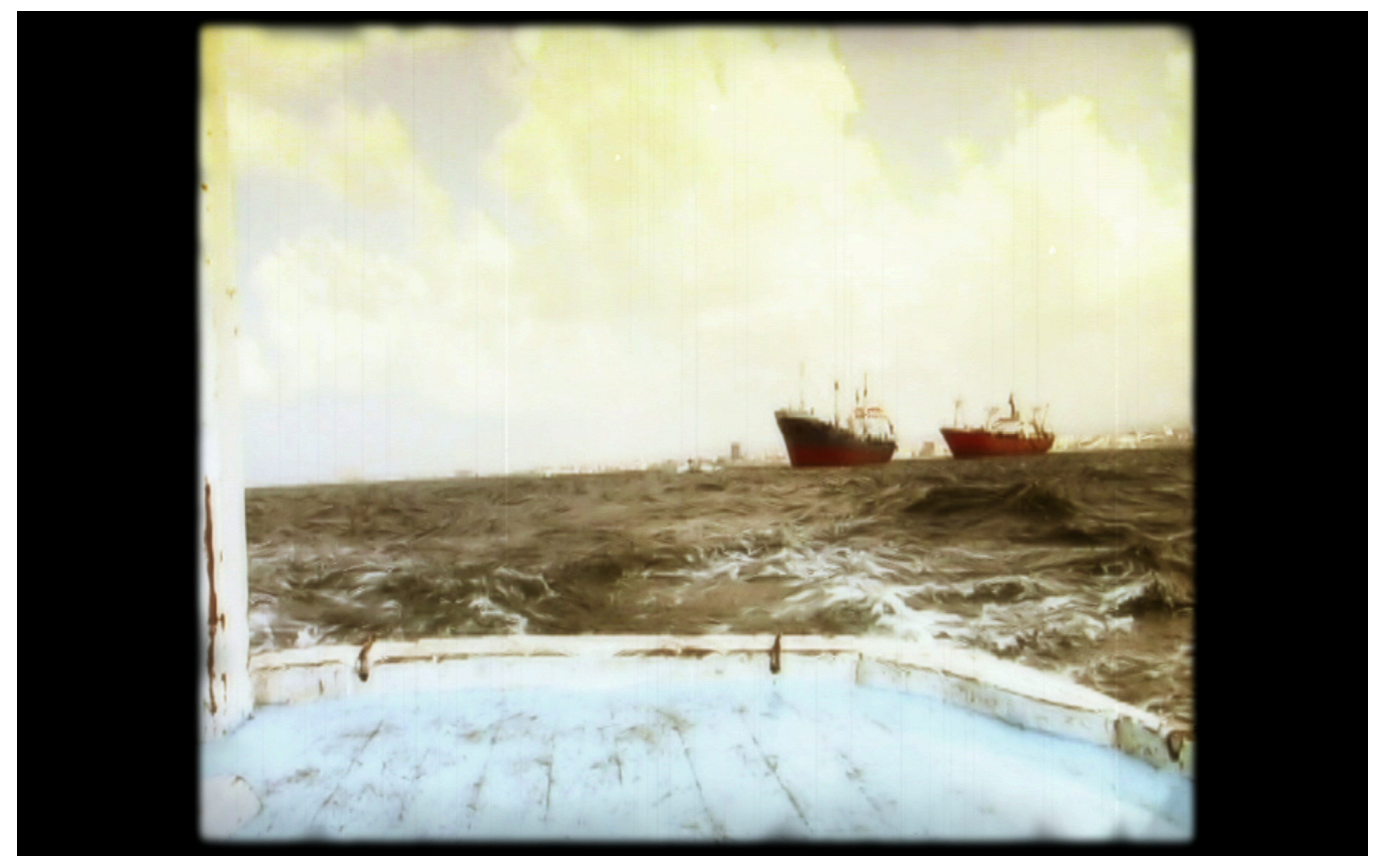

Se então Pan-cinema permanente dá conta de Waly Salomão na medida em que não o alcança, é porque, justamente, não é Waly, o personagem biografável, que seria singular, mas a relação que o filme estabelece com ele. Em uma experiência de desidentidade capaz de nos levar a lugares desconhecidos, maravilhosos, como a Síria ancestral e idílica, inventada, em que toda palavra poética instaura o mundo de que fala, Waly, ser centrífugo e excêntrico, nunca coincide consigo mesmo. Nessa dinâmica relacional e dialógica, constituinte de um processo abissal de simultânea indeterminação e ruptura entre identidade e alteridade, dinâmica que se faz belamente presente em um poema declamado pelo próprio poeta ${ }^{70}$, não há revelação nem verdade possível, pois os olhos de Waly, ao contrário da crença cristã que os remeteriam à "janela da alma", são, como diria João Guimarães Rosa, “a porta do abismo” (1988:66).

Não é por outro motivo que Waly Salomão não quer ser filmado de olhos fechados, dormindo. Não que haja aí um problema de ordem moral ou porque Waly vá perder o controle sobre sua imagem, como se costuma acreditar. Antes, o gesto de se filmar alguém dormindo coloca um problema estético e político: um problema de partilha. Se filmar é filmar relações, inclusive as que faltam, como tanto defende JeanLouis Comolli (2007:130), filmar alguém dormindo, ou mesmo fingindo que está dormindo, pouco importa, é negar qualquer possibilidade de relação, de partilha da

\footnotetext{
70 "Cresci sob um teto sossegado / meu sonho era um pequenino sonho meu / nas ciências dos cuidados fui treinado / agora, entre o meu ser e o ser alheio / a linha de fronteira se rompeu". (Poema "Câmera de ecos", Algaravias, 1996).
} 
imagem e, sobretudo no caso de Waly, de alteração do espaço da cena. "ALTERAR!", diz ele aos brados, alterar é função de toda ação, de toda existência política e poética.

Se, portanto, lidar com um personagem é fazer da escritura do filme uma forma de relação, em que o diretor se implica no filme na mesma medida em que perde o controle sobre ele, como escreve André Brasil (2008) a respeito da relação entre o diretor Andrea Tonacci e o índio Carapiru, em Serras da desordem, Pan-cinema permanente, em certo sentido, é um filme de Waly Salomão. Waly é pura autoficção e auto-estilização, cuja presença, uma espécie de personagem-diretor, parece determinar em diferentes circunstâncias as opções de Carlos Nader, seu diretor-personagem.

Não são raros os momentos em que, nessa forma de partilha, Waly dirige o olhar de Nader. A moça que, na Síria, dança na contraluz uma dança do ventre, a partir da indicação ou da ênfase de Waly, tem sua imagem fundida, pelo uso do som, a uma imagem captada pelo próprio Waly Salomão nos idos de 1970, em que um rapaz dançava, com a mesma ginga e malemolência, sob a contraluz de uma janela no Rio de Janeiro. Antes da passagem da imagem da moça na Síria para o rapaz no Rio de Janeiro, é no plano do som que os mais belos segundos de indeterminação se dão, como que antecipando essa passagem ou contágio: a música árabe se funde a "Vapor barato", o passado familiar e ancestral de Waly é presentificado, enquanto o presente da imagem já estava concebido em seu passado.

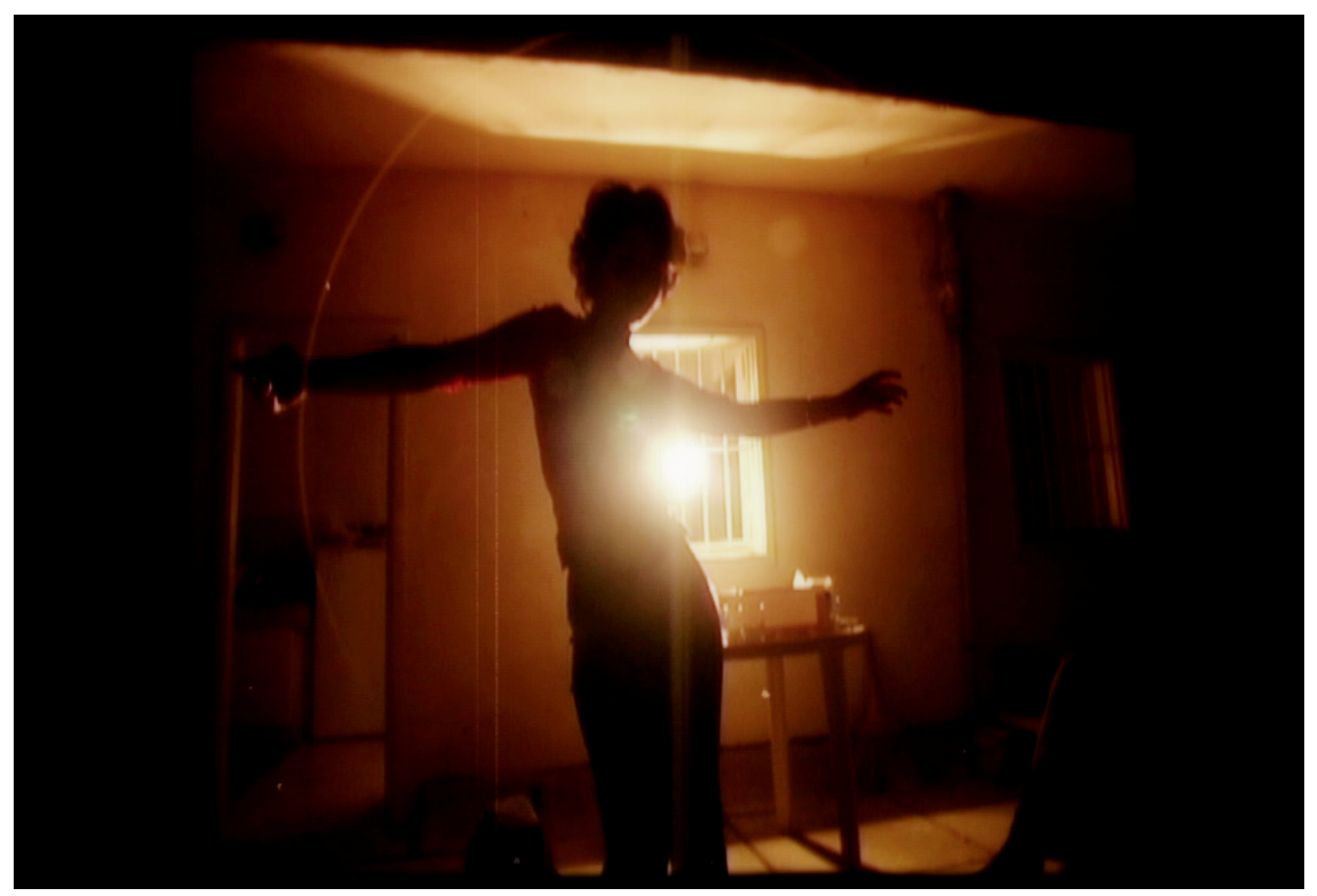




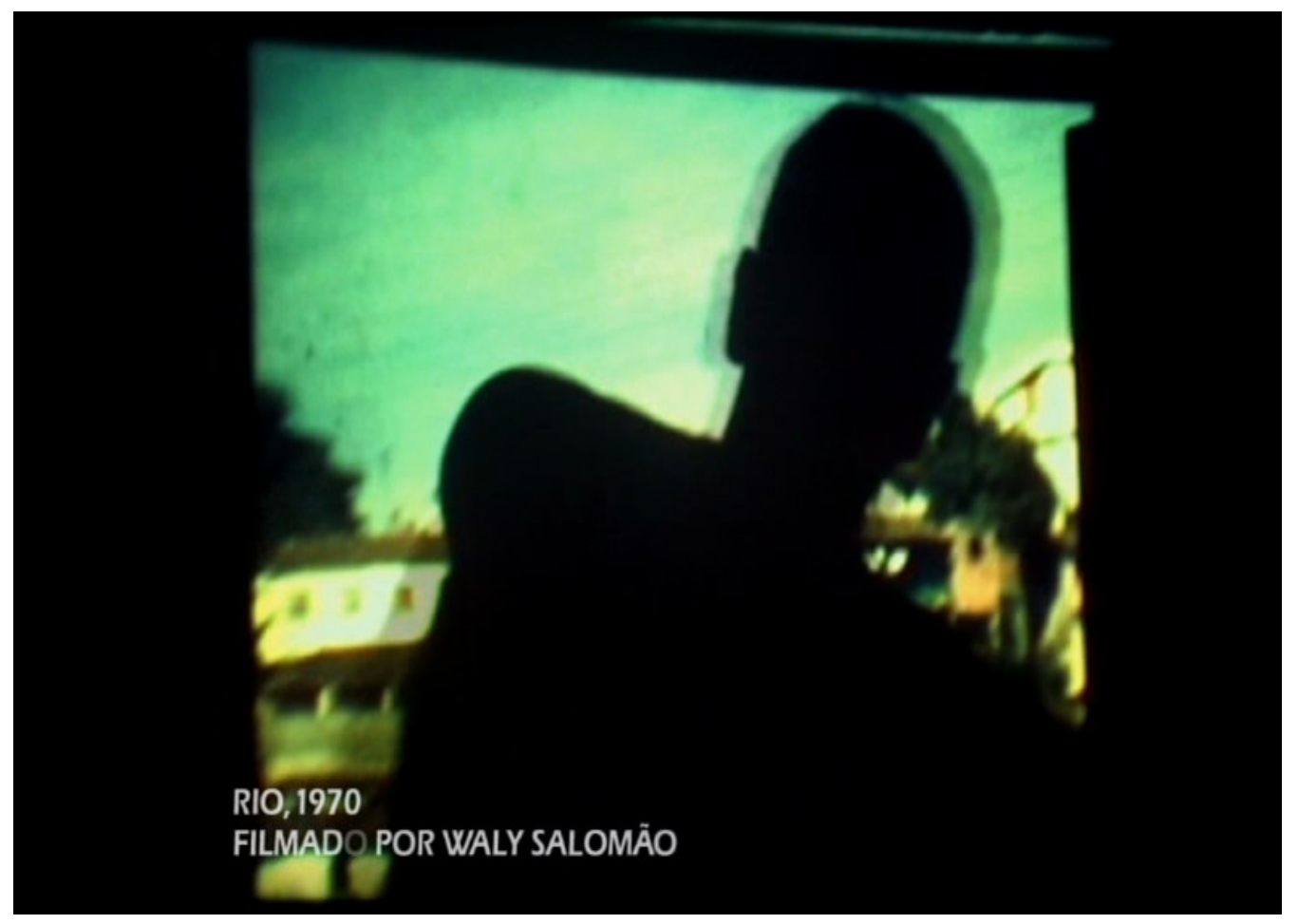

No entanto, a partir do princípio do prazer, que não se confunde com o gozo fetichista, e da alegria criadora, que não se conforma com nenhum tipo de jogo performático previamente calculado, a potência de Pan-cinema permanente talvez seja a de - distante de todos os cinismos - ultrapassar toda a indeterminação, em favor de uma afirmação permanente da alteração. Viver o real como artifício e o artifício como real, neste caso, não significa evitar o enfrentamento das contradições, mas encarar o irremediável fato de que somos seres que simulam, que inevitavelmente se ficcionalizam e que engendram mundos de sentidos, em geral incorporados como não inventados e recobertos por certo efeito de naturalização. Alterar, portanto, como tanto defendia e bradava Waly Salomão, não é simplesmente se abrir à indeterminação. Alterar é determinar a mudança.

Repensando nossa articulação, seria possível postular que esses dois modos de operar da indeterminação (materializados em Filmefobia e Pan-cinema permanente) efetivam não um paradoxo, mas uma duplicidade - e, nesse sentido, cada um dos filmes cristalizaria uma espécie de modelo teórico e crítico. A essa duplicidade da 
indeterminação poderíamos remeter a duplicidade da performance, esse conceito polissêmico e escorregadio que operaria, igualmente, em dois sentidos simultâneos porém de vetores contrários. Se, como vimos, em Filmefobia a performance, ao operar no domínio da representação, é instrumentaliza, ainda que essa instrumentalização da vida e da cena seja movida por uma inquietude, por um assombro, em Pan-cinema permanente a performance, operando em um domínio de fato performativo, seria aquilo que possibilitaria a permanente passagem do vivido ao imaginado, da natureza artificializada do gesto ao artifício naturalizado da mise en scène (Brasil, 2011), de modo que a cena nunca está dada previamente às relações que se forjam, que se imbricam ou que se põem em fuga no âmbito do filme.

Filiados a esse segundo modelo operatório, diversos filmes brasileiros contemporâneos - ao amortecer a dimensão representacional em detrimento da performativa - poderiam ser assomados, caso do explosivo A cidade é uma só ${ }^{71}$, de Adirley Queirós (2011), ou do marcante, mesmo que em seu baixo tom, O céu sobre os ombros, de Sérgio Borges (2010), filmes em que pessoa e personagem, experiência e roteiro, vida e escritura estão também indeterminados - e a alteração de qualquer um desses domínios parece implicar a imediata alteração do outro.

Assim como Pan-cinema permanente, $O$ céu sobre os ombros é também um filme habitado pelos corpos e por suas metamorfoses, porém lidando com personagens (entre o anonimato e o exotismo) habitantes das franjas sociais de uma grande cidade: Everlyn, uma transexual que faz doutorado em teoria dos gêneros e ganha a vida como prostituta (já que "putare" em latim é, segundo ela própria, uma forma de conhecimento); Murari, um rapaz que trabalha em uma operadora de telemarketing, é membro da torcida organizada do Atlético Mineiro e devota-se ao movimento Hare

\footnotetext{
${ }^{71}$ A cidade é uma só? (Adirley Queirós, 2011), ganhador do Prêmio do Júri da Crítica na Mostra de Tiradentes de 2012, escapa de um "efeito de indeterminação" bem composto e bem azeitado para, libertária e anarquicamente, trabalhar na simultaneidade dos registros e nas ambigüidades e curtoscircuitos entre os personagens. O filme, em princípio sobre a remoção, em 1971, de uma favela situada no coração da então jovem Brasília para a periferia da cidade - remoção que iria dar origem à cidade satélite de Ceilândia (cujo nome vem de CEI, Campanha de Erradicação de Invasões) -, traz a política, em seu sentido mais forte, para o centro da cena, como uma redistribuição do visível e do invisível, da palavra e do ruído, do que pode ser visto e dito (e de quem tem o poder para fazê-lo). Nessa outra forma de "partilha do sensível" (Rancière, 2005), todos parecem fazer parte de uma mesma família, para além de uma mesma comunidade: Dildu, um faxineiro candidato a deputado distrital em Cinelândia; um vendedor de lotes que trabalha contiguamente à especulação imobiliária na cidade satélite; e uma cantora que fora testemunha, quando criança, dessa remoção. Porém, ao longo das interações propostas pelo filme, vamos percebendo que Dildu é uma construção explicitamente ficcional que mobiliza e aciona acontecimentos que não existiriam sem sua presença, colocando todo o seu entorno político sob suspeita.
} 
Krishna; e Lwei, um escritor, não se sabe se imigrante, que não termina suas obras, tem um filho excepcional e a todo tempo põe em questão o sentido da vida e das palavras.

Como Waly, ali são todos multidimensionais e socialmente bordelines, “estranhos ímpares” no dizer de Drummond ${ }^{72}$, porém - em plano sempre fixo destituídos de reconhecimento público, aura artística e celebração poética. Ali, nesse filme de ausculta (e não simplesmente de escuta), nessa comunidade de corpos, de gestos e humores, vida, obra e devir convergem, sob o céu e sobre os ombros, para a mesma linha de fronteira que se rompeu ${ }^{73}$ - a linha da ficção e do documentário, da identidade e da alteridade, da vida e da cena, do singular e do comum, da crença e da suspeita.

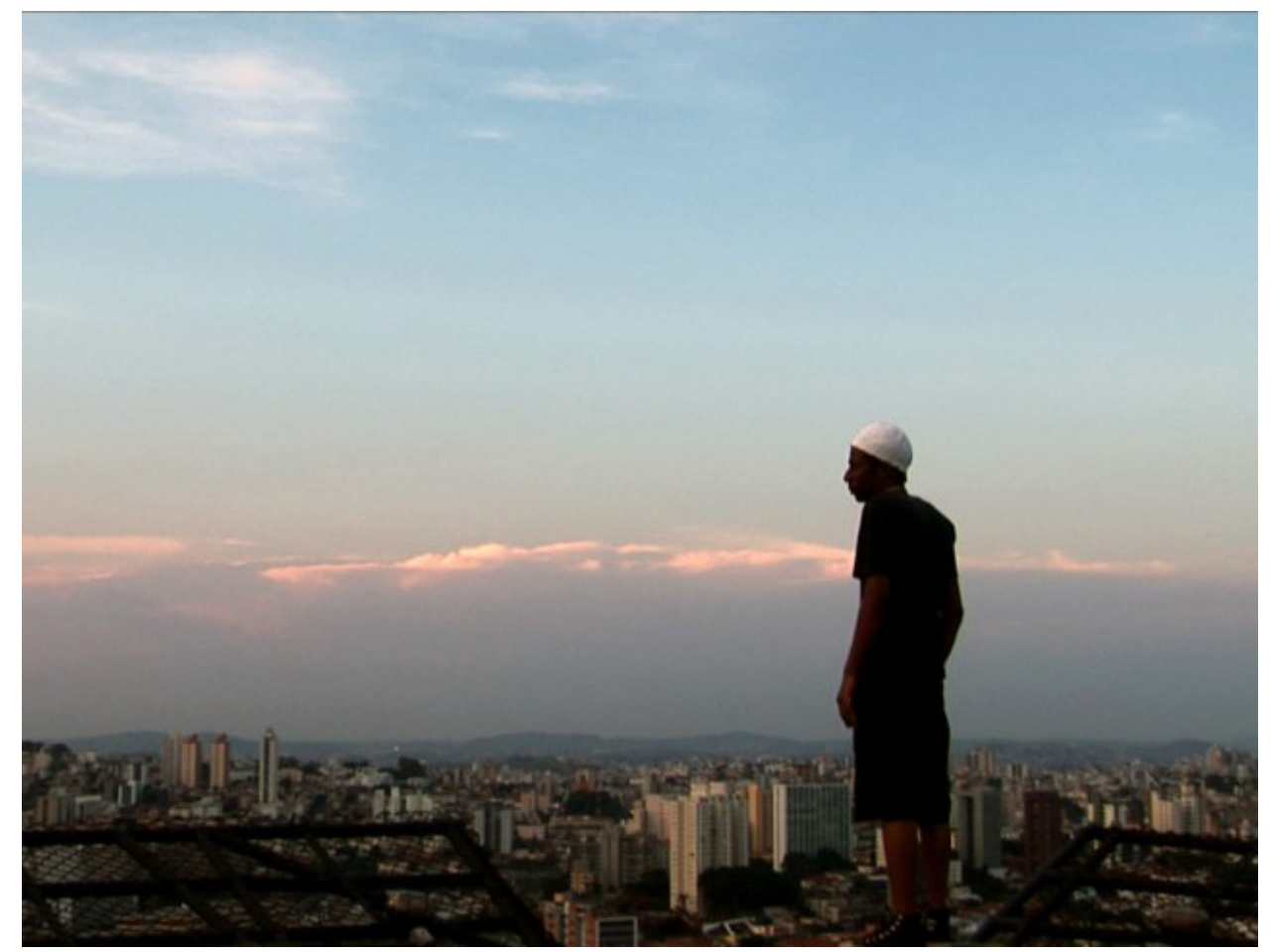

\footnotetext{
${ }^{72}$ Curiosamente, o poema "Igual-Desigual" de Carlos Drummond de Andrade começa com a seguinte suspeita: "Eu desconfiava (...)" e termina com o verso "Todo ser humano é um estranho ímpar". Sobre os "estranhos ímpares" em $O$ céu sobre os ombros, ver também COUTO, José Geraldo. "Roteiro? Pra que roteiro?”, em 18/11/2011. Disponível em: http://blogdoims.uol.com.br/ims/roteiro-pra-que-roteiro/

${ }^{73}$ Como no dizer do poema "Câmera de ecos", de Waly Salomão, em Algaravias, 1996.
} 


\section{Filmografia trabalhada}

Filmefobia, de Kiko Goifman (SP, 80’, 2009)

Pan-cinema permanente, de Carlos Nader (SP, 83', 2008)

\section{Filmografia comentada}

33, de Kiko Goifman (MG, 75', 2003)

Alô, alô, Terezinha, de Nelson Hoineff (RJ, 95', 2009)

O céu sobre os ombros, de Sérgio Borges (MG, 72’, 2010)

A cidade é uma só?, de Adirley Queirós (DF, 73', 2011).

Concepção, de Carlos Nader (SP, 16’, 2001)

Jesus no mundo maravilha, de Newton Cannito (SP, 52', 2007)

\section{Filmografia mencionada}

Avenida Brasília Formosa, de Gabriel Mascaro (PE, 84', 2010)

A bruxa de Blair, de Daniel Myrick, Eduardo Sánchez (EUA, 88', 1999)

Os desaparecidos, de David Schurmann (SP, 73', 2011)

Girimunho, de Clarissa Campolina e Helvécio Marins (MG, 90’, 2011)

Jogo de cena, de Eduardo Coutinho (RJ, 107’, 2007)

Juízo, de Maria Augusta Ramos (RJ, 100’, 2008)

Morro do Céu, de Gustavo Spolidoro (RS, 71', 2010)

Moscou, de Eduardo Coutinho (RJ, 78', 2009)

Nanook do Norte, de Robert Flaherty (EUA, 79’, 1922)

Serras da desordem, de Andréa Tonacci (SP, 135', 2006)

Santiago, de João Moreira Salles (RJ, 79’, 2007)

\section{Referências bibliográficas}

AGAMBEN, Giorgio. Homo Sacer - o poder soberano e a vida nua. Belo Horizonte: Ed. UFMG, 2002. 
. Estado de exceção. São Paulo: Boitempo, 2004.

Qu'est-ce que le contemporain? Paris: Payot \& Rivages, 2008.

.Moyens sans fins. Notes sur la politique. Paris: Payot \& Rivages, 2002.

BAZIN, André. “Ontologia da imagem fotográfica”. In: Ensaios. São Paulo: Brasiliense, 1991.

BERNARDET, Jean-Claude. "Documentários de busca: 33 e Passaporte húngaro". In: MOURÃO, Maria Dora; LABAKI, Amir (orgs.) O cinema do real. São Paulo: Cosac Naify, 2005.

BRASIL, André. "A performance: entre o vivido e o imaginado". Trabalho apresentado ao GT Comunicação e Experiência Estética, XX Encontro Anual da Compós, Universidade Federal do Rio Grande do Sul, Porto Alegre, de 14 a 17 de junho de 2011.

."Formas de vida na imagem: da indeterminação à inconstância", 2010. Trabalho apresentado ao GT Estéticas da Comunicação, XIX Encontro Anual da Compós, Puc-Rio, Rio de Janeiro, 2010.

."Carapiru-Andrea, Spinoza. A variação dos afetos em Serras da desordem". In: Devires - Cinema e Humanidades. UFMG, Belo Horizonte, v.5 n.2, 2008.

."Modulação/Montagem - Ensaio sobre biopolítica e experiência estética". Tese de Doutorado apresentada ao Programa de Pós-Graduação em Comunicação e Cultura, UFRJ, 2008.

;MIGLIORIN, Cezar. "Be stupid: a Diesel e o biopoder". In: Ciberlegenda - revista do Programa de Pós-Graduação em Comunicação da Universidade Federal Fluminense, Edição 22, $1^{\circ}$ sem. 2010. Disponível em: http://www.proppi.uff.br/ciberlegenda/be-stupid

CÍCERO, Antonio. "Os vídeo poéticos de Carlos Nader". Folha de São Paulo, Ilustrada, 04 abr. 2009.

COMOLLI, Jean-Louis. "Prefácio à edição francesa" e "Retrospectiva do espectador". In: Ver $e$ Poder, a inocência perdida: cinema, televisão, ficção e documentário. Ed. UFMG: 2008.

."Os homens ordinários. A ficção documentária". In: O comum e a experiência da linguagem. GUIMARÃES, C.; OTTE, G.; SEDLMAYER, S. (Orgs.) Belo Horizonte: UFMG, 2007.

DANEY, Serge. A rampa - Cahiers du Cinéma 1970-1982. São Paulo: Cosac Naify, 2007.

DEBORD, Guy. A Sociedade do Espetáculo. Rio de Janeiro: Contraponto, 2000.

DELEUZE, Gilles. A Lógica do Sentido. São Paulo: Perspectiva, 2003.

. "As potências do falso". In: A Imagem-Tempo. São Paulo: Editora Brasiliense, 2005.

DUCHET, Jean. "El arte de amar". Cahiers du cinéma, n.126, dez. 1961. In: BAECQUE, Antoine (org.). Teoría y crítica del cine. Buenos Aires: Paidós, 2005.

EDUARDO, CLÉBER. "Pan-cinema permanente: tudo é efeito". Revista Cinética, abr. 2008. Disponível em: http://www.revistacinetica.com.br/pancinema.htm

EHRENBERG, Alain. $O$ culto da performance - da aventura empreendedora à depressão nervosa. São Paulo: Idéias e Letras, 2010

FELDMAN, Ilana. "A vida em cena: vida-produto, vida-lazer, vida-trabalho, vidaperformance". In: Ciberlegenda - revista do Programa de Pós-Graduação em Comunicação da Universidade Federal Fluminense, Edição 22, $1^{\circ}$ sem. 2010. Disponível em: http://www.proppi.uff.br/ciberlegenda/vida-em-cena 
"Jogos de cena: indeterminação e ambigüidade sob suspeita em alguns filmes brasileiros recentes". Comunicação apresentada ao XIII Encontro Socine, ECA/USP, São Paulo, 2009 , inédita.

"Reality show: um dispositivo biopolítico". In: Estéticas da biopolítica: audiovisual, política e novas tecnologias. Revista Cinética / Programa Cultura e Pensamento (MinC), 2008. Disponível em: http://www.revistacinetica.com.br/cep/ilana_feldman.htm

FERÁL, Josette. "Performance e performatividade: o que são os Performance Studies?. In: MOSTAÇO, Eldécio; OROFINO, Isabel; COLAÇO, Vera (orgs.). Sobre a performatividade. Florianópolis: Letras contemporâneas, 2009.

FERRAZ, Maria Cristina Franco. "Teatro e máscara no pensamento de Nietzsche”. In: Nove variações sobre temas nietzschianos. Rio de Janeiro: Relume Dumará, 2002.

FOUCAULT, Michel. História da sexualidade, vol.1, A vontade de saber. Rio de janeiro: Graal, 1997. "Aula de 17 de março de 1976". In: Em defesa da sociedade. São Paulo: Martins Fontes, 2005;

.O nascimento da biopolítica". In: Resumo dos cursos do Collège de France (1970-1982). Rio de Janeiro: Jorge Zahar, 1997.

HUIZINGA, Johan. Homo ludens. São Paulo: Perspectiva, 2008.

LINS, Consuelo; MESQUITA, Cláudia. "Crer, não crer, crer apesar de tudo - a questão da crença nas imagens na recente produção documental brasileira". Trabalho apresentado ao XVII Encontro Anual da Compós - GT Fotografia, Cinema e Vídeo. UNIP, São Paulo, SP, 2008.

LINS, Consuelo; GERVAISEAU, Henri; FRANÇA, Andréa. "Serge Daney: o cinema como abertura para o mundo". In: Cinemais n 15, jan/fev de 1999.

MAFFESOLI, Michel. O instante eterno: o retorno do trágico nas sociedades pós-modernas. São Paulo: Zouk, 2003.

MESQUITA, Cláudia. "Retratos em diálogo - notas sobre o documentário brasileiro recente". In: Novos estudos CEBRAP, n.86, março 2010.

MIGLIORIN, Cezar. "Eu sou aquele que está de saída - dispositivo, experiência e biopolítica no documentário contemporâneo". Tese de Doutorado apresentada ao Programa de PósGraduação em Comunicação e Cultura, UFRJ, 2008.

OITICICA, Hélio. "Anotações sobre o Parangolé" e "Situação da vanguarda. In: Aspiro ao grande labirinto. Rio de Janeiro: Rocco, 1986.

RANCIÈRE, Jacques. Le spectateur émancipé. Paris: La Fabrique, 2008. . Malaise dans l'esthétique. Paris: Galilée, 2004. . A partilha do sensivel. São Paulo: Ed 34, 2005.

ROSA, Guimarães. "O espelho”. In: Primeiras histórias. Rio de Janeiro: Nova Fronteira, 1988. Grande Sertão: Veredas. Rio de Janeiro: José Olympio, 1982.

SAFATLE, Vladimir. Cinismo e falência da crítica. São Paulo: Boitempo, 2008. Lacan. São Paulo: Publifolha, 2009.

"Confrontar-se com o inumano". Dossiê Jacques Lacan, revista Cult, 125, ano 11,

2008. 
"O envelhecimento do moderno". Entrevista concedida a Juliano Gentile e Thais Rivitti, em 05/01/2007. http://forumpermanente.incubadora.fapesp.br/portal/.rede/numero/revnumero6/

SENNETT, Richard. O declínio do homem público - as tiranias da intimidade. São Paulo: Cia das Letras, 2002.

VELLOSO, Silvia Pimenta. "O perspectivismo em Nietzsche". In: DANOVSKI, Débora; PEREIRA, Luiz Carlos. O que nos faz pensar. Cadernos do Departamento de Filosofia da PUCRio, set. 2004.

ZIZEK, Slavoj. Bem-vindo ao deserto do Real. São Paulo: Boitempo, 2003. "Le Sujet Interpassif". In: La subjectivité à venir. Paris: Champs Flammarion, 2006.

ZUMTHOR, Paul. "Em torno da ideia de performance". In: Performance, recepção, leitura. São Paulo: Cosac Naify, 2007. 
CAPÍTULO III 


\title{
O trabalho do amador:
}

\author{
Pacific (Marcelo Pedroso, 2009) e algumas companhias
}

\section{Reposição da distância}

Imagens amadoras, domésticas, precárias. Imagens emergenciais, instáveis, fugidias. O que está em jogo quando as empresas de comunicação, os telejornais, os shows de realidade e variedades na televisão, o cinema, a arte contemporânea e a publicidade disputam essas "mesmas" imagens? O que se aproxima como sintoma, como roteirizada ordem do dia, e o que se distancia pelos gestos, conscientes e reflexivos, de apropriação e deslocamento dessas imagens, de configuração de novos trabalhos de mediação, novos modos de subjetivação e novas práticas de manipulação das imagens de arquivo?

De fato, para uns, a apropriação das imagens amadoras, dos vídeos domésticos e dos filmes de família configura uma lucrativa e oportuna estratégia de solicitação da participação, do engajamento e da colaboração dos até então "passivos" espectadores (leia-se: cidadãos consumidores) que devem, a todo custo, mobilizar-se, tornar-se ativos e interativos. Já para outros, a apropriação do trabalho dos amadores configura um espaço de criação, deslocamento, análise e ressignificação, tanto dessas imagens quanto dos lugares ocupados por todos nós, espectadores-montadores ${ }^{74}$. Expressando-se provocativamente, e não sem melancolia, Alexandre, personagem do belo filme $L a$ maman et la putain, de Jean Eustache (França, 1973), diria: "Falar com as palavras dos outros. É isso que eu gostaria. Deve ser isso a liberdade”.

Se na cotidiana apropriação das imagens amadoras pela mídia e pela publicidade irrestrita (como vemos na recente campanha publicitária de uma das maiores instituições bancárias do país ${ }^{75}$ ) ou mesmo na simulação delas pelos variados gêneros e

\footnotetext{
74 Sobre a passagem do "espectador crítico" ao "espectador-montador", já que, segundo Georges DidiHuberman, "o conhecimento se faz por montagem", ver LINS, Consuelo."Do espectador crítico ao espectador-montador: Um dia na vida, de Eduardo Coutinho". In: Devires, Belo Horizonte, v. 7, n. 2, p. 132-138, jul/dez 2011.

${ }^{75}$ Em sua primeira campanha publicitária de 2012, o banco Itaú - que há tempos vem investindo em estratégias publicitárias colaborativas - se apropriou de um vídeo amador extremamente popular no Youtube (no qual um bebê gargalha quando seu pai corta pedaços de papel), para, a partir dele, fazer uma campanha contra o desperdício de papel e em favor dos extratos bancários on-line. Ao contrário do que ocorre com as empresas de comunicação e os cinegrafistas/internautas amadores que oferecem "conteúdo colaborativo" gratuitamente, sem nenhuma remuneração em troca, ou em troca da visibilidade de suas
} 
modos do cinema (dos filmes-catástrofe de Hollywood a projetos independentes e artisticamente legitimados ${ }^{76}$ ) está em jogo uma tentativa de apagamento da distância e das mediações, para que essas imagens possam operar como "dados brutos" e "autênticos" do real - e assim legitimar as empresas que delas se apropriam ou os projetos estéticos a que elas se filiam -, é notável como em alguns documentários brasileiros contemporâneos percebemos estratégias de vetores opostos, que dialogam com o sintoma ao mesmo tempo em que dele se afastam.

Para esses filmes, caso de Pacific (Marcelo Pedroso, 2009), filme aqui privilegiado, e tantos outros ao qual, por perspectivas ou aspectos diversos, poderíamos articular - como Avenida Brasília Formosa (Gabriel Mascaro, 2010), Um dia na vida (Eduardo Coutinho, 2010), o nem tão recente Rua de mão dupla (Cao Guimarães, 2004) e mesmo a ficção Viajo porque preciso, volto porque te amo (Marcelo Gomes e Karim Ainouz, 2009), para nos atermos ao cinema brasileiro - trata-se de, por meio de sutis deslocamentos operados pela montagem, repor certa distância, problematizar a mediação, desfazer a pregnância da ilusão referencial e esvaziar o "apelo realista",77 que emana dessas imagens, no caso de Pacific aparentemente tão imediatas ou tão pouco mediadas. Trata-se assim de uma operação que desloca o índice para o performativo, ao mesmo tempo em que torna indistinguível o trabalho de invenção de si e o trabalho de criação das imagens, as performances e as mise en scènes, a produção de valor e os fluxos do capital.

Para esses filmes, pautados por um permanente corpo a corpo entre os sujeitos e os dispositivos, a relação entre poder, ver e saber implicada nas posturas do enunciador (muitas vezes recolhido diante do que enuncia) e na posição do espectador (muitas vezes em dúvida diante do que vê) torna-se objeto de permanente questionamento,

imagens, neste caso o pai do bebê fora remunerado por um trabalho "imaterial" (a capitalização da presença do filho) que ele, a princípio, não produzira para tal fim. Ver http://www.meioemensagem.com.br/home/comunicacao/noticias/2012/01/09/Itau-leva-para-TV-bebe-hitdaweb.html

${ }^{76}$ Não por acaso, a estética própria ao filme de Super 8, vinculada ao apelo indicial dos filmes de família e amadores, às produções experimentais ou undergrounds e aos códigos estéticos da memória, nunca dantes estivera tão em voga, tanto em filmes prestigiados e legitimados artisticamente quanto em grandes produções de Hollywood, caso do filme Super 8 (J.J Abrams, EUA, 2011), produzido por Steven Spielberg. Antes, porém, de Super 8, o tradicional gênero do cinema-catástrofe (exemplo maior do investimento dos grandes estúdios em efeitos especiais e simulações de mundos) já havia encontrado os efeitos de real das imagens amadoras em um filme como Cloverfield (Matt Reeves, EUA, 2008), produzido por J.J Abrams (que viria a ser o diretor de Super 8) e integralmente narrado a partir do trêmulo ponto de vista de um de seus personagens. Ao promover uma fusão entre os "efeitos especiais" e os "efeitos de real", Cloverfield é o exemplo supremo daquele cenário tão bem identificado por Jean-Louis Comolli (2001): "No auge do triunfo do espetáculo espera-se um espetáculo que não mais simule".

${ }^{77}$ Conforme nosso trabalho. Ver FELDMAN, Ilana. "O apelo realista". In: Revista FAMECOS, "Dossiê Menções de Destaque - Compós 2008”, Porto Alegre, n.36, ago. 2008. 
suspeita e desconcerto. Não se trata mais, entretanto, daquela reposição da distância que pautara certas agressivas estratégias anti-ilusionistas ${ }^{78}$ do cinema moderno, como vemos em tantos filmes de Jean-Luc Godard a partir de fins dos anos sessenta (sobretudo com a criação do Grupo Dziga Vertov, de orientação maoísta e inspiração brechtiana, entre 1968 e 1972), mas da consciência da distância e da separação como condição mesma de toda e qualquer relação, seja no âmbito do cinema, da vida ou do pensamento. Como escrevera um dia Serge Daney (1992), em um dos mais tocantes e políticos textos críticos já escritos: "E o cinema, vejo muito bem porque o adotei: para que ele me adotasse de volta. Para que ele me ensinasse a perceber, incansavelmente pelo olhar, a que distância de mim começa o outro.”

Em Pacific, o modo epidérmico como nos aproximamos, por meio do filme, desse outro, dessa alteridade radical que nos é desconcertantemente tão próxima, estranha e familiar, pessoal e comum, explicita uma contigüidade entre as formas do filme e as formas do mundo, entre o performado e o vivido. Nesse gesto de pilhagem consentida - das imagens amadoras, domésticas e tremulantes dos outros, os passageiros do cruzeiro Pacific que empresta seu nome ao filme, o realizador Marcelo Pedroso, espécie de cineasta-pirata dos novos tempos ("pirataria" sustentada pelo consentimento legal e voluntarismo pessoal de seus personagens), cria uma linha tênue entre proximidade e distância, possivelmente se afastando do que enuncia para melhor se fundir, ou para se confundir. Fusão, confusão e indeterminação - entre enunciados e enunciação, pessoa e personagem, intimidade e visibilidade, público e privado, vida e cena - que deixa a todos nós, espectadores, em um lugar tão instável como a ardilosa superfície do mar.

\section{Navio-auditório, trabalho e classe média espontânea}

$\mathrm{Na}$ primeira seqüência de Pacific somos instalados em um mar ensolarado, trepidante e profundamente azul ao longo de uma cadeia de montanhas. Ouvimos algumas vozes, mas não sabemos ainda do que se trata, quando a câmera treme, perde o foco e, em meio a gritos de entusiasmo, se perde no profundo azul até que surjam alguns golfinhos bem próximos ao que parece ser um barco. A mesma voz masculina

\footnotetext{
${ }^{78}$ A esse respeito, ver o capítulo "Os filhos de Ubu: a abstração e a agressão do antiilusionismo", em STAM, Robert. O espetáculo Interrompido - literatura e cinema da desmistificação. Rio de Janeiro: Paz e Terra, 1981.
} 
que já havia sido notada antes então grita, exultante, "Agora valeu!”, “Agora sim!”, "Eu já ia pedir meu dinheiro de volta!", enquanto uma voz feminina declara que esperou 50 anos para ver essa cena e alguém mais fala em "espetáculo". Em meio ao entusiasmo geral com os saltitantes bichinhos, a tela escurece e uma voz de criança pergunta a seu pai, "Fimou?", ao que ele responde, "Filmei, lógico!"

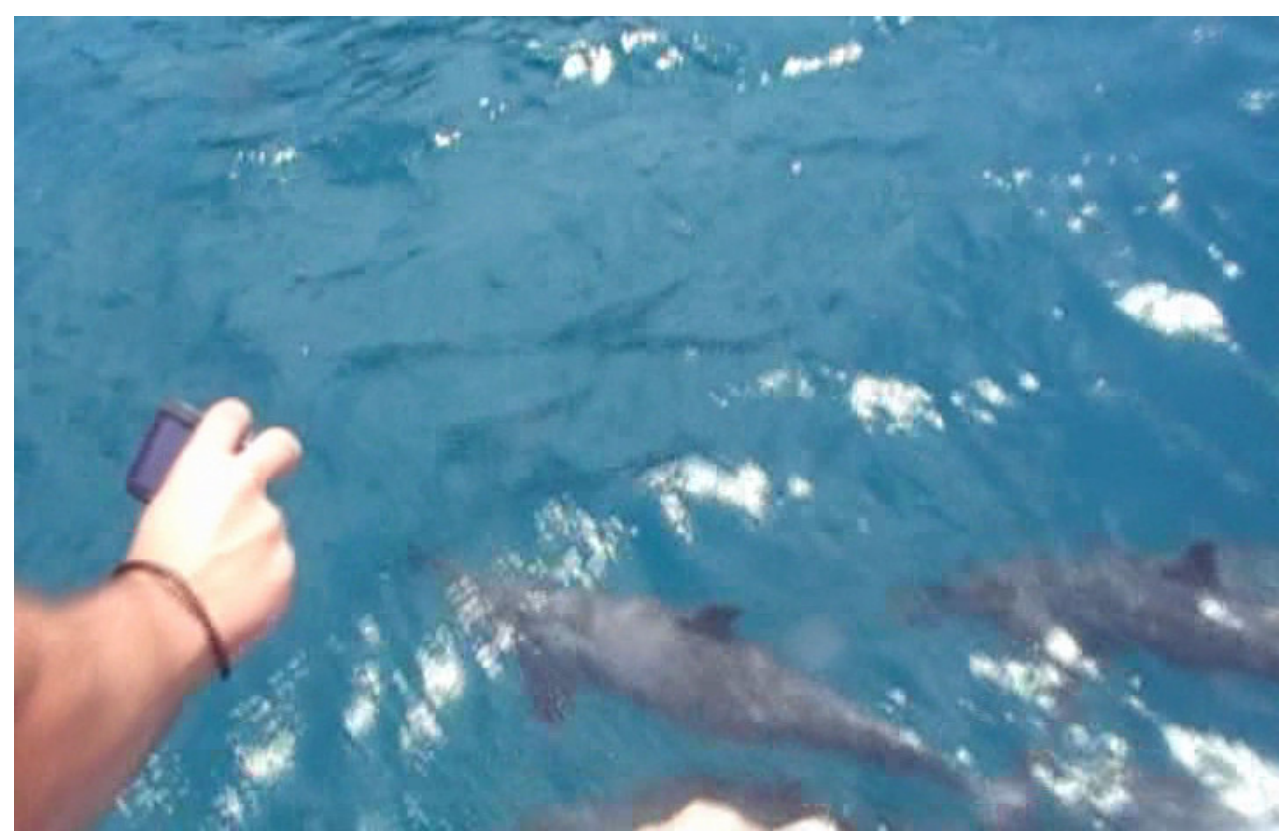

A partir daí, o filme revela com palavras inscritas sobre uma superfície preta o seu dispositivo: em dezembro de 2008 uma equipe de pesquisa participou de viagens, de Recife à ilha de Fernando de Noronha, a bordo do cruzeiro Pacific, e, após identificar passageiros que estavam filmando a viagem e se filmando, sem estabelecer qualquer tipo de contato com eles, convidou-os a ceder suas imagens para um documentário. Após essa cartela explicativa, única intervenção explícita do realizador que não voltará mais a aparecer, somos lançados a um plano extremamente próximo e não muito compreensível, quando, pouco a pouco, vamos percebendo que se trata do ponto de vista de alguém que ao tentar filmar uma mulher (sua esposa, mãe, tia ou avó) acaba por filmar, desajeitadamente e em super close, a pele dela.

Ao organizar narrativa e epidermicamente imagens domésticas captadas por passageiros do cruzeiro Pacific, cujo trajeto, de Recife a Fernando de Noronha às vésperas da celebração do Réveillon, promete realizar os sonhos de excitação permanente de uma classe média à vontade, "espontânea" e emergente, o diretor Marcelo Pedroso realiza um filme tão desconcertante quanto urgente. Por meio de sutis 
deslocamentos de sentido operados pela montagem, Pacific problematiza ordens diversas de deslocamento, enunciação recolhida, distância crítica, engajamento afetivo, construção de si e um tipo particular de "arquivo vivo". Esse navio-auditório, reserva de lazer e imaginação (Brasil, 2010), mas também espaço de permanente trabalho e (auto)produção, pode ser percebido não apenas como um navio, mas como um dispositivo ou laboratório onde se performam as formas de vida hegemônicas no contexto dos novos regimes de subjetividade e visibilidade de nosso capitalismo tardio, flexível e biopolítico ${ }^{79}$.

Performando-se para as suas próprias câmeras, construindo-se para as suas próprias imagens, os passageiros de Pacific, como quaisquer turistas, colecionam e acumulam experiências, sensações e imagens-síntese de um lazer adquirido a suadas prestações do cartão de crédito - e, que, portanto, precisa ser maximizado. "Que nossos queridos passageiros tenham todos mais um excelente espetáculo!”, diz, para a platéia de passageiros com filmadoras em punho, o apresentador do navio-auditório, onde não pode haver tempo morto nem pausa, observação distanciada nem contemplação passiva. No "ócio produtivo" do navio-auditório que o filme Pacific nos apresenta é preciso ser permanentemente participativo, interativo e colaborativo. Pois a vida aqui, seja encenada para si, encenada para o outro ou encenada para nós - ainda que à força do deslocamento dessas imagens, que deixam de habitar o âmbito da privacidade para tornarem-se publicidade - é, em realidade, produto de um inesgotável trabalho.

Como nos alerta André Gorz, em $O$ imaterial - conhecimento, valor e capital, a partir do diagnóstico de Yann Moulier-Boutang, no contexto de um capitalismo “imaterial" ${ }^{80}$ e biopolítico cujo núcleo da produção econômica é a própria vida, a

\footnotetext{
79 Grosso modo, o conceito de biopolítica, postulado por Michel Foucault em 1976, pode ser compreendido como os modos pelos quais as políticas públicas, os dispositivos sócio-técnicos e, hoje, a dinâmica neoliberal do capitalismo avançado de consumo se voltam aos processos vitais, moleculares e sociais da existência humana. Se as outrora estatais biopolíticas nascem como uma modalidade de poder sobre a vida e de governo da vida, hoje, privatizadas e hiper-individualizadas, as biopolíticas se disseminam como técnicas de autogestão, instrumentalização e modulação dos indivíduos (em meio à indeterminação entre autonomia e sujeição, prazer e controle, liberdade e restrição) pautadas por valores empresariais de custo-benefício e por demandas de otimização da performance e atualização permanente. Para uma abordagem inicial, ver textos de Michel FOUCAULT (conforme bibliografia). Para os desdobramentos contemporâneos, ver DUARTE, André. "Sobre a biopolítica: de Foucault ao século XXI”. In: FELDMAN, llana; BRASIL, André; MIGLIORIN, Cezar (Orgs.) In: Estéticas da biopolítica audiovisual, política e novas tecnologias. Programa Cultura e Pensamento (MinC) / Revista Cinética, 2008.

${ }^{80} \mathrm{O}$ regime de produção dito pós-industrial ou pós-fordista, regido pelo capitalismo financeiro e pautado não mais pela lógica da produção e do acúmulo, mas pela logística da circulação e do consumo, tem ensejado, segundo diversos autores, um novo modo de agenciamento capitalista (para o qual as propriedades da vida ganham uma centralidade inédita) denominado "capitalismo imaterial" ou “cognitivo". Ver: NEGRI, Antonio; LAZZARATO, Maurizio. Trabalho imaterial. Rio de Janeiro:
} 
criatividade, o imaginário, o conhecimento, a comunicação e as imagens, "o trabalhador não se apresenta mais apenas como possuidor de uma força de trabalho, mas como um produto que continua, ele mesmo, a se produzir" (apud Gorz, 2005:19). Tal diagnóstico, entretanto, não é exatamente recente. Em 1970, Felix Guattari já havia apontado precisamente para o fato de que, se na primeira fase da revolução industrial os indivíduos eram transformados em autômatos, cujos gestos - assim como a vida social deveriam ser fragmentados, "agora, cada vez mais, no seio mesmo da evolução das forças produtivas, está colocado o problema das singularidades, da imaginação, da invenção. Cada vez mais o que será demandado aos indivíduos na produção é que eles sejam eles mesmos" (apud Migliorin, 2009:260).

Assim, nessa "mobilização total" (Gorz, 2005:22) das capacidades e disposições afetivas dos indivíduos, baseada em valores como autonomia, espontaneidade, mobilidade, cooperação, criatividade, motivação e convivialidade - valores que não por acaso regem as dinâmicas empresariais, os jogos televisivos, a cultura terapêutica dos manuais de auto-ajuda e que Pacific tão explicitamente torna visível -, não é mais possível saber quando estamos fora do trabalho que pensamos realizar. Pois, no limite, não é mais o sujeito que adere ao trabalho, mas o trabalho que adere à vida mesma dos sujeitos, como se não houvesse mais exterioridade possível, como se não houvesse mais fora. O que não significa, que fique claro, que o trabalho propriamente industrial e mesmo o capitalismo extrativista foram abolidos ou ultrapassados. Muito ao contrário. O que ocorre hoje é a co-existência desses modos de produção, de sujeição e de subjetivação - que implicam, por sua vez, distintos modos de visibilidade ${ }^{81}$.

Nessa perspectiva, não seria exagero supor que Pacific significaria para o mundo do lazer no século XXI o que Um homem com uma câmera, de Dziga Vertov (União

DP\&A, 2001; COCCO, Giuseppe. Capitalismo cognitivo - trabalho, redes e inovação. Rio de Janeiro: DP\&A, 2003; BOLTANSKI, Luc; CHIAPELLO, Ėve. O novo espírito do capitalismo. São Paulo: Martins Fontes, 2009; bem como livros e artigos de Yann MOULIER-BOUTANG, Bernard ASPE e Muriel COMBES.

${ }^{81}$ Um bom exemplo midiático da co-existência desses modos de produção e visibilidade é o caso dos 33 mineiros chilenos que ficaram presos, entre agosto a outubro de 2010, debaixo de uma mina de cobre no norte do Chile. Sem ver a luz do dia e sob o permanente risco do fracasso da operação de resgate e da iminência da morte, eles eram monitorados por imagens difundidas pelas agências noticiosas de todo o mundo. Antes mesmo do resgate bem sucedido (acompanhado por milhões de telespectadores e que os levou da total invisibilidade de suas profissões à condição de celebridades imediatas), notícias de que o drama dos mineiros iria virar um filme já corriam pelo mundo, com nome provisório, Los 33, e direção do chileno Rodrigo Ortúzar. Segundo site do jornal O Estado de S. Paulo, em 25/07/2011, um novo acordo, porém, foi assinado com o produtor de Hollywood Mike Medavoy (mais conhecido pela produção de Cisne Negro, de Darren Aronofsky, 2010). 
Soviética, 1929) ${ }^{82}$, significou para o mundo do trabalho nas primeiras décadas do século XX. Excetuando-se a dimensão utópica e a crença revolucionária do projeto de Vertov, em Um homem com uma câmera trabalho e lazer estão a princípio muito bem separados, mas se o fim de uma jornada de trabalho significa, de um lado, uma exterioridade em relação ao mundo da fábrica, de outro, também significa a continuidade, no lazer, da mesma energia maquínica e produtivista que rege o mundo industrial e fabril. Ou seja, o momento do lazer em sociedade em Um homem com uma câmera já era uma forma de trabalho e de produção, acompanhada inclusive da presença do olho-maquínico de um cinegrafista-operário que, imanente ao corpo social, tudo filma e tudo vê, em busca da "vida de improviso" (busca que décadas depois iria também pautar os cinemas modernos, os reality shows e os amadores por vir) e das condições de construção da própria realidade fílmica e social.

Voltando a Pacific, é importante notar que o contexto de classe, a ênfase no perpétuo trabalho de produção de si e criação das imagens e a ancoragem desse recorte em um universo de classe média emergente, filha do crescimento econômico da Era Lula, conferem ao filme extrema relevância, tornando-o uma resposta consciente à tímida presença desse universo social em nossa cinematografia. Com raras exceções, como em A opinião pública (Arnaldo Jabor, 1967), Retrato de classe (Gregório Bacic, 1977) e Edifício Master (Eduardo Coutinho, 2002), para mencionarmos exemplos emblemáticos (e que evidentemente não dão conta da multiplicidade e abrangência da produção brasileira ${ }^{83}$ ), a investigação das “imagens da classe média” pelo documentário, presumivelmente a classe social dos realizadores, tradicionalmente tendeu a permanecer obscurecida em relação às questões consideradas socialmente mais relevantes, em relação à investigação do "outro de classe".

\footnotetext{
${ }^{82}$ Para uma abordagem inicial da paradigmática importância do filme de Vertov na história do documentário, ver os capítulos "A invenção de uma escritura documental" e "Antiilusionismo e Autoreflexividade". In: DA-RIN, Silvio. Espelho partido: tradição e transformação no documentário. Rio de Janeiro: Azougue, 2004. Ver também "O futuro do homem? Em torno de $O$ homem com a câmera, de Dziga Vertov". In: COMOLLI, Jean-Louis. Ver e poder: a inocência perdida - cinema, televisão, ficção, documentário. Belo Horizonte: UFMG, 2008.

${ }^{83}$ Evidentemente, "classe média" é uma denominação genérica e excessivamente ampla, e, nos filmes indicados, há diversos extratos das camadas médias da sociedade brasileira em jogo. No entanto, como o objetivo aqui não é definir o que seria essa classe (socialmente abrangente e extremamente desigual), mas perceber os filmes que introjetam, em suas escolhas, uma perspectiva de classe, vale destacar também os documentários $O$ último a sair fecha a porta (Carolina Fernandes e Alessandro Sócrates, 2009), sobre a emigração legal de paulistanos, com curso superior e diplomas nas mãos, a Quebec, no Canadá, e Romance de formação (Julia De Simone, 2011), perfil sintético de quatro jovens que estudam longe de casa, alguns em universidades estrangeiras. Curioso notar a partir desses dois exemplos de que modo no documentário hoje essa perspectiva de classe tende a se elitizar (uma resposta clara a nossa tradição documental de invisibilidade das elites) e a ser pautada por exemplos de "empreendedorismo" pessoal.
} 
No entanto, se o documentário no Brasil historicamente sempre se pautou a dar voz aos excluídos e a dar visibilidade a questões e reivindicações sociais silenciadas, a partir, na maior parte dos casos, da estabilidade de posições consensuais, de algumas décadas para cá o "mandato popular" dos cineastas e documentaristas - que então falavam "em nome de" - vem sendo posto em questão. Em entrevista a Mario Sergio Conti para o jornal Folha de São Paulo nos anos 2000, Ismail Xavier ${ }^{84}$ aponta que já a partir dos anos 70 os cineastas passaram a desconfiar de seus referenciais, de suas posições supostamente privilegiadas para falar em nome dos outros e, enfim, de seus mandatos como representantes de um saber. A partir de então, tem início no campo do cinema e do documentário um movimento, correlato às ciências humanas, de revisão ideológica, questionamento das "vozes do saber", autoproblematização dos agentes dos discursos e recolhimento da enunciação fílmica (em favor da observação mais distanciada ou do privilégio da entrevista e dos testemunhos), ensejando o que Ismail Xavier identifica, nessa mesma entrevista, como "etnografia discreta" - isto é, uma aproximação sutil dos contextos sociais e das perspectivas históricas que deixariam de ser as "estruturas" determinantes dos indivíduos.

Assim, o documentário brasileiro contemporâneo, em um movimento de particularização ou "redução do enfoque" (Mesquita, 2010) e de recusa ao que é "representativo", suspeita de procedimentos totalizantes e interpretativos, estando mais preocupado em repor e afirmar as "singularidades" dos sujeitos que, há décadas atrás, na produção documental dos anos 60 e 70, eram representados por categorias sociais e genéricas - amenizando, desse modo, as determinações sociais do contexto ${ }^{85}$. Tal deslocamento de ênfase do quadro geral para o particular, do diagnóstico para a expressão singular, da interpretação para a produção de presença $^{86}$ e da dimensão

\footnotetext{
${ }^{84}$ Ver "Ressentimento e realismo ameno", entrevista a Mario Sérgio Conti (publicada originalmente na FSP, 03/12/2000). In: MENDES, Adilson (org.) Ismail Xavier. Rio de Janeiro, Azougue, 2009. p.102. Sobre o "sentimento de perda do mandato" e "fim da utopia do cinema moderno", ver também, na mesma coletânea, "O cinema brasileiro dos anos 90", entrevista a Ricardo Musse (publicada originalmente na revista Praga, número 9, em 2000), p.112.

${ }^{85}$ Sobre a recusa ao que é "representativo" e a afirmação de sujeitos "singulares", ver o capítulo "Contrapontos com o documentário moderno". In: LINS, Consuelo; MESQUITA, Cláudia. Filmar o real - sobre o documentário brasileiro contemporâneo. Rio de Janeiro: Jorge Zahar, 2008.

${ }^{86}$ Contra a "cultura do sentido", fundada na vocação interpretativa de nossa moderna tradição hermenêutica cuja tarefa exclusiva seria atribuir ou extrair sentidos, "profundos" e "ocultos", do que analisa, Gumbrecht propõe a "cultura da presença". Para o autor alemão, a possibilidade de se restabelecer contato com as coisas do mundo fora do paradigma sujeito/objeto exige a análise daquilo que podemos experimentar, primordialmente, fora da linguagem, ao mesmo tempo em que a linguagem é, ela também, produtora de presença. Ver GUMBRECHT, Hans Ulrich. Produção de presença - o que o sentido não consegue transmitir. Rio de Janeiro: Contraponto / Ed. PUC-Rio, 2010.
} 
representacional para a performativa ${ }^{87}$ vincula-se ao que a ensaísta Beatriz Sarlo chamou de "guinada subjetiva", quando, análoga às transformações da sociologia da cultura, da micro-história, da antropologia e dos Estudos Culturais, "a identidade dos sujeitos voltou a tomar o lugar ocupado, nos anos 1960, pelas estruturas" (2007:19). Segundo Sarlo, com isso "restaurou-se a razão do sujeito, que foi, há décadas, mera 'ideologia' ou 'falsa consciência'” (ibid).

Essa particularização do enfoque acrescida da intensificação da dimensão performativa (em detrimento da representacional) presente nitidamente em várias manifestações da cultura que não apenas o cinema, se, de um lado, tende a esvaziar o documentário de uma dimensão social, pública e política (no sentido, digamos assim, tradicional e consensual do termo), de outro, não sem problematizações, permite a migração da política do tema para a política do olhar e da forma de narrar. O que não significa pensar em uma migração histórica, como se os documentaristas de outrora dissociassem a política da forma do tema político. Muito ao contrário. O que ocorre hoje é que aquelas formas estéticas que, no contexto do documentário moderno, eram percebidas e valoradas como formas de engajamento político vão, à medida do tempo, dos debates ideológicos e dos impasses estéticos, sendo percebidas e reavaliadas de outra maneira. Se, portanto, assim como os cineastas, o documentário também teria perdido seu mandato para representar em nossos dias a experiência social e coletiva, faz-se necessário, mais do que nunca, pensar as possibilidades do coletivo e da comunidade (um comum cujas partes entrem em relação pelas diferenças, e não por uma suposta unidade) a partir das reconfigurações, que os filmes dão a ver, em curso nos campos do trabalho, dos afetos e da linguagem. Isto é, a partir das relações, engajadas no presente, que os filmes forjam e que se forjam por meio dos filmes.

Transitando nessa permanente tensão entre as forças sociais e as formas estéticas, entre uma "etnografia discreta" de outros universos sociais e uma "autoetnografia", não tão discreta assim (seja dos personagens, que passam a produzir suas próprias imagens, seja dos próprios cineastas, que se expõem e se tematizam reflexivamente ${ }^{88}$ ), outras obras, por aspectos distintos, poderiam ser articuladas a

\footnotetext{
${ }^{87}$ André Brasil problematiza os modos como a figuração da vida ordinária, na mídia, nas artes e no cinema, avança da representação à experiência, e a imagem deixa de ser apenas um lugar de visibilidade para se tornar, intensamente, um lugar performance, isto é, um lugar "onde se performam formas de vida". Ver BRASIL, André. "Formas de vida na imagem", Trabalho apresentado ao GT Estéticas da Comunicação, XIX Encontro Anual da Compós, Puc-Rio, Rio de Janeiro, 2010.

${ }^{88}$ Documentários auto-reflexivos e auto-etnográficos, narrados na primeira pessoa do singular, têm sido cada vez mais recorrentes em nossa cinematografia (e um pouco tardiamente, se compararmos com a
} 
Pacific, tais como: Rua de mão dupla (Cao Guimarães, 2004), Avenida Brasília Formosa (Gabriel Mascaro, 2010) e Viajo porque preciso, volto porque te amo (Marcelo Gomes e Karim Ainouz, 2009) - em um movimento que se Hal Foster (1996), no terreno das artes visuais de fins de século XX, já havia identificado com a expressão "o artista como etnógrafo", também em relação à literatura latino-americana e brasileira contemporânea, Diana Klinger (2007) muito apropriadamente definiu como "o retorno do autor e a virada etnográfica".

Nessa relação entre auto-etnografia e etnografia, os filmes elencados a cima ora são estruturados por imagens exclusivamente produzidas por outros que não o cineasta, como ocorre em Pacific (caso também de Rua de mão dupla, embora em Rua de dupla essas imagens sejam, desde o início, mobilizadas pelo e para o dispositivo do filme), ora incorporam em sua própria estrutura imagens produzidas, ou aparentemente produzidas, por seus próprios personagens (como em Avenida Brasília Formosa), ora simulam, a partir de uma narração em primeira pessoa ficcional e da reapropriação de imagens previamente filmadas e não necessariamente endereçadas ao filme, uma perspectiva auto-reflexiva que não abre mão do inventário e da observação de paisagens, regiões e habitantes do interior do país (caso de Viajo porque preciso, volto porque te amo).

Antes de retomarmos esses filmes adiante, é interessante perceber de que forma Pacific indiferencia ou indetermina a incorporação de imagens de outros (personagens do documentário, passageiros do navio) e de imagens outras (não originalmente produzidas para o documentário). Nesse movimento de apropriação, mas também de contígua separação, avizinhado ao gesto ensaístico que desloca objetos culturais préformados para produzir anacronismos, os outros e as imagens outras são o que nos atravessam, o que nos ultrapassam, mas também o que nos escapam, na forma do desconcerto, da perplexidade ou de um estranho encantamento. Afinal, nessas relações dialógicas e perspectivadas, amalgamadas por esses filmes, não se pode chegar

explosão das narrativas em primeira nos anos 80 em outros países), em um movimento de intensificação do performativo - e o "performático" será, justamente, um dos "modos de representação" (uma contradição em termos) identificados por Bill Nichols (2005) em sua conhecida taxonomia do documentário, modo no qual a subjetividade do realizador é enfatizada frente a outras modalidades de construção narrativa. Filiados a essa tendência, muitos filmes brasileiros recentes poderiam ser mencionados, desde os filmes "de busca" (Bernardet, 2005), como Um passaporte húngaro (Sandra Kogut, 2003), 33 (Kiko Goifman, 2003) e Diário de uma busca (Flávia Castro, 2011), aos filmes que introjetam em suas investigações subjetivas e de linguagem a consciência (e conseqüente problematização) da classe social do cineasta, caso de Santiago (João Moreira Salles, 2007) e de Babás (Consuelo Lins, 2010). 
suficientemente próximo do outro sem se tornar, também, um outro (Klinger, 2007:147).

\section{Valeu!}

Caracterizado como um flutuante não-lugar de excepcionalidade ou exceção (afinal, supostamente, as férias seriam a interrupção de uma rotina de trabalho), Pacific, o navio-laboratório, assim como Pacific, o filme, acionam a indeterminação, tão cara à nossa época, entre privacidade e publicidade (em seu duplo sentido), lazer e trabalho, intimidade e visibilidade, vida e performance. A performance, esse conceito polissêmico, movediço e cujo "inacabamento" tanto nos interessa, seria aqui compreendida como elemento operatório das dinâmicas subjetivas e capitalistas em jogo em uma sociedade "flexível", no âmbito de um capitalismo que, como vimos, se pode ser denominado biopolítico, imaterial ou avançado de consumo, também poderia ser identificado como um "capitalismo afetivo", de acordo com a tese da socióloga Eva Illouz (2011).

Segundo a autora, ao longo do século $\mathrm{XX}$ as esferas econômica e afetiva passaram a se mesclar de forma inseparável, em uma intensa "cultura das emoções", pois, enquanto de um lado as transações econômicas tornaram-se mais afetivas, por influência da psicanálise e do feminismo, de outro, os relacionamentos íntimos foram influenciados em grande medida por modelos de negociação e gestão. Por isso, se as performances atuam em uma zona de indistinção entre vida, experiência estética e capital - dificilmente diferindo a produção de si dos fluxos capitalistas -, é porque, em Pacific, as performances se dão em meio a essa intensiva cultura das emoções. Para tal cultura, forjada, de saída, pelo dispositivo de Pacific (o cruzeiro), o prazer pessoal deve ser maximizado e administrado de acordo com relações de custo-benefício e retorno dos investimentos, em um contexto em que as dinâmicas capitalistas operariam como um sistema de produção e gestão dos afetos. Um capitalismo, por assim dizer, "amador"?

Não é por acaso então que a seqüência inicial de Pacific, antes mesmo de o filme se instalar no navio, tenha privilegiado a reação de alguns dos personagens às imagens por eles produzidas: “Agora valeu!”, “Agora sim!”, "Eu já ia pedir meu dinheiro de volta!". Assim, o gesto de filmar e de filmar-se não se inscreve apenas como mero registro, para documentação e construção da memória, ainda que esse aspecto mnemônico do filmar para arquivar, partilhar ou, cada vez mais, deletar, seja inegável. 
Antes, para os passageiros-personagens do cruzeiro Pacific, filmar é também comprovar a publicidade que lhes fora feita, validar o capital investido, assim como validar as próprias imagens por eles produzidas. Nesse sentido, não são poucos os momentos em que a imagem é empregada estritamente para asseverar e legitimar o dinheiro gasto. E, talvez, o mais emblemático deles seja quando um cardápio, cujas bebidas, drinks e pratos são destituídos de preço, é enquadrado pela câmera: imagem-síntese daquela situação de exceção em que, na restrição do espaço confinado do navio e da duração da viagem, todo o excesso é liberado, estimulado e administrado ${ }^{89}$.

Mas em geral, se as imagens produzidas e o dinheiro investido constituem uma mediação incontornável para os passageiros do navio e personagens do filme (e aqui não há como não lembrar da definição de Guy Debord acerca do "espetáculo"90), observa-se também uma exigência da imagem em sua dimensão narrativa, sensível, estética. Uma exigência da imagem em sua possibilidade de produzir, intensificar e prolongar a experiência, ou seja, em sua dimensão performativa. Se a imagem tem de valer como prova, validação do próprio consumo, ela também tem de valer como evidência da fabulação, em um momento em que os "amadores" (no duplo sentido da não-profissionalização e da explicitação dos afetos) dominam cada vez mais os códigos e as sintaxes audiovisuais. Lembremos das performances e das encenações deliberadas para a câmera: um casal se filma romanticamente ao piano, ele encena tocar e cantar em inglês, acompanhando a trilha sonora romântica imposta pelo navio; ela apóia a câmera sobre o piano e, entrando em quadro, se junta a ele, beijando sua testa. Já outro casal, mais jovem, na proa do Pacific, encena parodicamente, abrindo os braços e cantando aos berros, o momento-clímax de Titanic.

\footnotetext{
${ }^{89}$ Dinâmica de restrição e liberação, controle e estímulo, tão própria aos reality shows de confinamento e convivialidade administrada, como o paradigmático Big Brother Brasil. A diferença é que a vigilância objetiva do dispositivo onisciente e onipresente do reality é, em Pacific, transferida, internalizada e exercida pelos próprios indivíduos, em meio ao entretenimento, à afetividade e à autonomia. Nesse sentido, tanto o dispositivo do cruzeiro Pacific quanto o dispositivo dos reality shows de confinamento sustentam-se nesse duplo vínculo entre o que Michel Foucault chamara de "técnicas políticas" (como as formas de vigilância, controle e administração) e "tecnologias do eu" (como os modos de subjetivação).

${ }^{90}$ Segundo Debord: "O espetáculo é o capital elevado a um tal grau de acumulação que se torna imagem". Em DEBORD, Guy. A Sociedade do Espetáculo. Rio de Janeiro: Contraponto, 2000, p.20.
} 

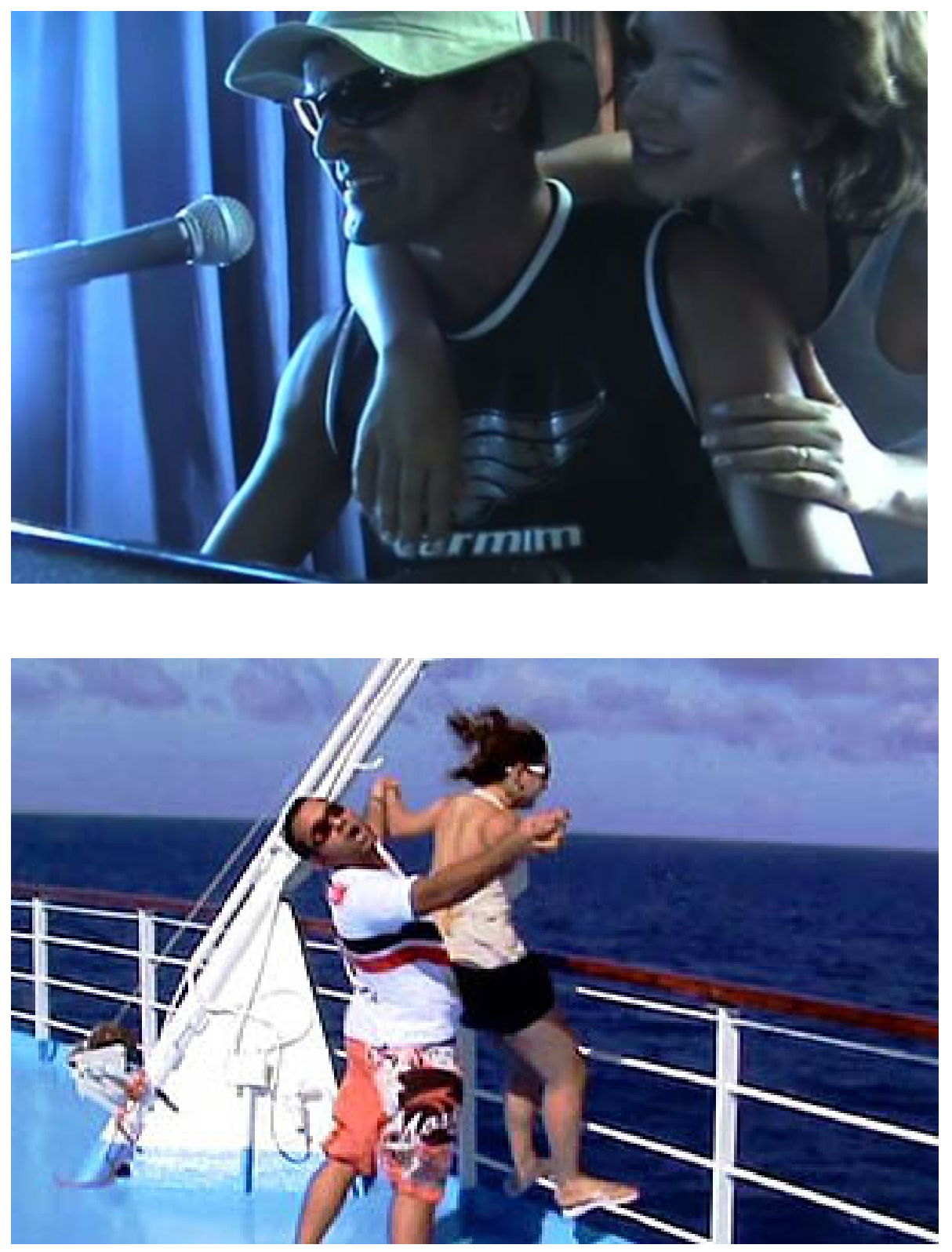

Em Pacific, não existe, portanto, experiência que não passe pela mediação com a imagem, ao mesmo tempo em que essa mediação - por meio das imagens amadoras, tremidas, desfocadas, precárias, mas extremamente conscientes - promete, paradoxo dos paradoxos, um suposto acesso a uma experiência supostamente não-mediada. Como diria Jean-Luis Comolli (2001), pensando das grandes produções hollywoodianas aos games, dos reality shows ao telejornalismo, do documentário às experiências da arte contemporânea: "No auge do triunfo do espetáculo, espera-se um espetáculo que não mais simule". Desse modo, se de um lado o "espetáculo" quer dissimular-se como construção, fundindo-se aos efeitos de real (que visam obliterar a mediação e assim 
intensificar o mergulho na ficção, tomando-a por realidade) $)^{91}$, de outro, o lugar da vida ordinária que escapa ao "espetáculo" e que sempre interessou ao documentário é, também ela, cada vez mais parte constitutiva de uma ficcionalização, fabulação ou teatralização do cotidiano, fundindo-se com os efeitos de irreal (para os quais o Real, de tão inapreensível, apareceria já como ficção) ${ }^{92}$.

Com isso, não significa dizer, em consonância com certas doxas pósmodernizantes, que a vida cotidiana tem sido mascarada ou falseada por uma espécie de "totalizante simulacro" que encobriria - tal como o "antigo véu" da ideologia - a realidade social. O que está em jogo no âmbito desse corpo a corpo entre os sujeitos e os dispositivos de produção de imagens e sons, entre os sujeitos e o efeito-câmera ${ }^{93}$, catalisador de um tipo de atitude que não existiria sem a presença do aparato, é um permanente jogo de cena. Gerados pelos curtos-circuitos entre entronização do olhar (a imersão do espectador em uma aparente absorção da cena em si mesma) e teatralização da experiência (o deslocamento do espectador da cena devido aos excessos exibicionistas ou performáticos), os jogos de cena contemporâneos, tão visíveis em Pacific, não se restringem ao cinema, sobretudo em um momento histórico em que o cinema perdera sua centralidade como consumo cultural, embora nele ainda encontrem uma caixa de ressonância privilegiada e um modelo operatório paradigmático que catalisa determinadas atitudes e disposições.

\footnotetext{
${ }^{91}$ Em sua clássica análise cujo ponto de partida é o conto "Um coração simples", de Flaubert, Roland Barthes (2004) cunha o disseminado conceito de efeito de real (em artigo originalmente publicado na revista Communications, em 1968). Para Barthes, em um relato realista, a descrição de um elemento insignificante da narrativa contribui para aumentar a verossimilhança interna da ficção: estratégia que implica uma intensificação da verdade da ficção na medida mesma em que a mediação, a escritura do relato, tende a ser apagada, obliterada ou esquecida como tal.

${ }^{92}$ A paixão pelo Real, postulada por Slavoj Zizek (2003) a partir de Lacan, implica, ao contrário do efeito de real bartheano, uma paixão pelo semblante, já que o Real, inapreensível e irrepresentável por seu caráter excessivo e traumático, não poderia jamais integrar o que chamamos de realidade, retornando sempre como um "efeito", como "ficção". Por essa razão, em sua análise do romance Nove Noites, de Bernardo Carvalho, Diana Klinger identifica a paixão pelo Real a um efeito de irreal. Ver KLINGER, Diana. Escritas de si, escritas do outro - o retorno do autor e a virada etnográfica. Rio de Janeiro: 7Letras, 2007, p.150.

${ }^{93} \mathrm{O}$ efeito-câmera se exerce, como instância do olhar, na criação de um campo visível que ganha uma dimensão de cena, potencializando experiências e vivências (que já são parte do cotidiano dos indivíduos) de acordo as regras dos jogos de cena do momento. Ver XAVIER, Ismail. "El exemplar y lo contingente en el teatro de las evidencias", revista Pensamiento de los Confines v.25, Buenos Aires, 2009. Importante também notar que tal efeito-câmera poderia ser identificado ao "poder psicanalítico" da câmera, poder que tem sido debatido desde os anos 20 na teoria do cinema. A esse respeito ver os textos de Jean Epstein e Béla Bálazs em XAVIER, Ismail (Org.) A experiência do cinema. Rio de Janeiro: Graal, 1983; assim como XAVIER, Ismail. "O efeito-janela e a identificação". In: O discurso cinematográfico - a opacidade e a transparência. São Paulo: Paz e Terra, 2005.
} 
Antes, os jogos de cena contemporâneos dizem então respeito, por meio do cinema e para além do cinema, às complexas e difusas dinâmicas sociais que atravessam a vida cotidiana dos indivíduos, contígua aos fluxos do capitalismo, curto-circuitando com suas mise en scènes os âmbitos do público e do privado, da vida e da cena, da intimidade e da visibilidade.

\section{Naufrágio da intimidade}

Se o capitalismo industrial fora marcado pelo "declínio do homem público" e pelas "tiranias da intimidade", como defende o sociólogo inglês Richard Sennet (2002), hoje, no contexto das mutações do capitalismo contemporâneo, estaríamos vivenciando também importantes transformações na maneira pela qual os indivíduos configuram e vivenciam suas experiências subjetivas, as quais deixaram de se ancorar em uma interioridade psicológica moderna e burguesa (um tipo de caráter introdirigido, elaborado no silêncio e na solidão dos espaços privados) para se ancorarem na exterioridade dos corpos e das imagens (um tipo de caráter alterdirigido), como enfatiza Paula Sibilia em $O$ show do eu - a intimidade como espetáculo (2008).

Nesse panorama em que, como já demonstrara Michel Foucault em sua genealogia do sujeito moderno, a subjetividade é inseparável dos dispositivos de visibilidade, em que as máquinas de ver produzem modos de ser - e de aparecer -, proliferam de maneira crescente novas práticas amadoras, autobiográficas, confessionais, interativas e performativas em um momento histórico no qual a intimidade (tal como modernamente a entendíamos) parece estar em deslocamento ou declínio - e, no caso de Pacific, certamente em naufrágio. Sequiosos de "publicidade" e operando na indeterminação entre público e privado, pessoa e personagem, lazer e trabalho, espontaneidade e encenação, vida e performance, uma série de dispositivos comunicacionais e audiovisuais contemporâneos, das redes sociais aos reality shows, do cinema à arte contemporânea, trabalham na chave não da "invasão de privacidade", mas de sua evasão.

Entretanto, em tal contexto, a intimidade não existiria como uma instância previamente dada, mas como efeito de uma série de operações de linguagem. Como nos alerta Fernanda Bruno, no artigo "Máquinas de ver, modos de ser: visibilidade e subjetividade nas novas tecnologias de informação e comunicação" (2004), diferentemente da tópica da subjetividade moderna, não se trata agora da exteriorização 
de uma interioridade constituída, por natureza recôndita, que passa a se expor, mas principalmente de uma subjetividade que se constitui prioritariamente na própria exterioridade, no ato mesmo de se projetar e de se fazer visível a outrem. Tal é o caso da proliferação de imagens amadoras, filmes de família, diários audiovisuais e de pessoas, como os passageiros do cruzeiro Pacific, que cedem voluntariamente suas imagens, supostamente pessoais, para serem exibidas em um filme. O que fica claro, como bem ressalta Jean-Claude Bernardet (2011) em seu blog na internet, que as imagens dos passageiros de Pacific não fizeram a passagem do âmbito privado ao público, pois elas já foram construídas como exterioridade, conscientes do olhar alheio e do fazer-se visível. O que o gesto do cineasta faz, ao deslocar essas imagens de seus empregos originais, organizando-as narrativamente e transformando-as em uma experiência cinematográfica, é, portanto, intensificar essa dimensão de exterioridade que as imagens já portavam em si mesmas.

Nesse ponto, cabe-se perguntar se as imagens domésticas, os vídeos caseiros ou filmes de família, "gênero" que de certa forma nasce com o próprio cinema - afinal, muitos dos primeiros filmes dos irmãos Lumière, tal como o famoso $O$ almoço do bebê (1895), foram filmados em família -, já não seriam feitos com a consciência do olhar alheio e do fazer-se visível, com a consciência dessa conduta cênica implicada pelo efeito-câmera. Muito antes, porém, da popularização e difusão das tecnologias digitais de captação de imagem e som já se percebe nesses filmes de antanho marcas de uma (auto) mise en scène, de uma teatralização do cotidiano diante da câmera, na forma de elaborados enquadramentos, pequenos esquetes cômicos, micro-narrativas, poses, decupagem, rituais sociais (como batizados, casamentos e nascimentos) e, até, em alguns casos mais sofisticados, truques de montagem - como fica claro nos arquivos particulares, de famílias húngaras das décadas de 30 e 40, reapropriados por Péter Forgács em obras como A família Bartos (1988), Queda Livre (1996) e O turbilhão (1997), para citar apenas algumas.

Seja nos filmetes dos Lumière de fins do século XIX, seja nos filmes das ricas famílias, estrangeiras ou brasileiras, das décadas de 20, 30 e 40, já se percebe, portanto, uma extrema consciência da imagem e seletividade do que se filma (em função do modo de produção dessas imagens, captadas em película), ao contrário da crença corrente em uma suposta intimidade e certo espontaneísmo que emanariam dessas (ingênuas?) imagens. No ensaio "Ruínas da intimidade: os 'objetos encontrados' de Péter Forgács", Consuelo Lins e Thaís Blank (2012) chamam atenção para diversos aspectos da obra do 
artista húngaro, salientando que os filmes domésticos encontrados e reapropriados por Forgács, ao serem deslocados de seus arquivos e usos originais (já que não foram feitos para sair do âmbito da família) e retrabalhados na montagem (guardadas as devidas diferenças, assim como em Pacific), não podem ser vistos como ilustrações de um real preexistente, mas sim como "ruínas da intimidade", de onde o artista, por meio de uma "escavação" das imagens, extrai dos pequenos dramas individuais os destinos de uma época. No entanto, caberia problematizar se de fato trata-se de "intimidade", já que momentos em família, sobretudo filmados e conscientes da presença da câmera, não significam momentos íntimos, como se fossem mais resguardados e menos mediados. Em vários desses filmes nota-se justamente o contrário: de um lado, percebemos as mise en scènes que essas imagens revelam em si mesmas, a despeito da pregnância de seus efeitos de real; de outro, tendo em vista justamente tais efeitos de real, observamos uma espécie de reposição da distância que Forgács empreende por meio da montagem.

Diferentemente dessas longínquas décadas já passadas, nas quais a posse dos aparatos de filmagem, ao menos no âmbito privado, era um lazer marcadamente de elite, apenas nos últimos trinta anos, com a chegada do VHS na década de 80 e a passagem do sistema analógico para o magnético - e, posteriormente, para o digital -, houve uma democratização do acesso às câmeras domésticas e, mais recentemente, a popularização de toda sorte de dispositivos comunicacionais para os quais a captação de imagem e som é apenas mais um dos recursos disponíveis. Nesse processo, alterou-se mais do que os modos de produção, circulação e consumo desses materiais, agora não mais restritos ao usufruto familiar, ao âmbito privado, mas muitas vezes disponibilizados em canais de compartilhamento de arquivos na internet e consumidos por um público participativo (engajados em fazer disseminar, "viralmente", essas imagens). Alterou-se mais do que as formas de consciência diante da imagem, agora intensificada, ainda que essa intensificação da percepção do efeito-câmera implique, paradoxalmente, a sua naturalização. Nesse processo, alterou-se, definitivamente, a classe social dos agentes dos discursos, portadores das câmeras.

No entanto, é preciso lembrar que tal transformação social em curso não implica necessariamente uma efetiva mudança de conduta diante da câmera. Encenações burlescas, momentos cômicos e a exploração do patético podem ser vistos em abundância entre os filmetes do cinema dos primeiros tempos (espécie de genealogia das "pegadinhas" e "vídeo-cassetadas"), assim como atravessam a saga da burguesa 
família húngara Bartos, mesmo às vésperas de uma tragédia histórica ${ }^{94}$ (como vemos na imagem do filme de Forgács, A família Bartos), do mesmo modo que comparecem nos filmes domésticos de ricas famílias de São Paulo nos anos 20, como o clã Alves de Lima. Segundo pesquisa de Lila Foster (2011:115), nas imagens depositadas na Cinemateca Brasileira dessa abastada família paulistana, nota-se, para além dos ares cosmopolitas afinados aos comportamentos transformadores dos modernistas, uma atitude bastante zombeteira, flertando mesmo com a encenação do ridículo. Ridículo e patético que, embora travestidos de outros códigos estéticos e narrativos - e no contexto de outra classe social -, estão intencionalmente presentes nas atitudes auto-paródicas e nas situações cômicas produzidas por vários dos personagens de Pacific (motivo, aliás, pelo qual as críticas mais conservadoras tenderam a rejeitar o filme ${ }^{95}$ ).

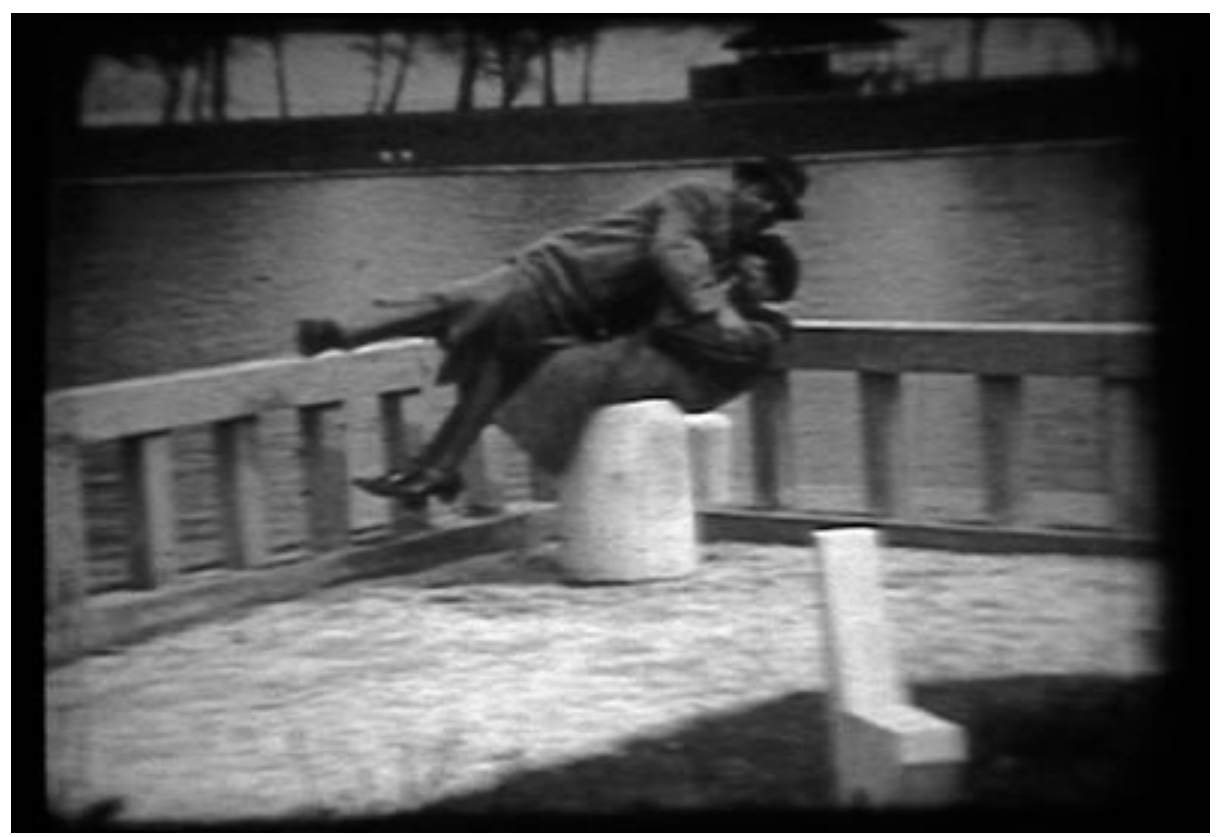

Sendo assim, para além das diferenças já apontadas no que diz respeito às mudanças tecnológicas, às alterações dos modos de produção, circulação e consumo

\footnotetext{
${ }^{94}$ A iminência da "solução final" na Segunda Guerra Mundial, sobretudo na Hungria, é uma espécie de macabro e terrível contracampo dos filmes de Forgács. Neles, sobretudo nos filmes que constituem a série "Hungria particular", não há imagens de campos de extermínio e de sofrimento explícito, mas situações de "normalidade" familiar em meio a um mundo prestes a ruir (o que provoca em nós, espectadores, uma apreensão permanente), exceção a $O$ filme de Angelo (1999), em que o empresário e cinegrafista amador Angelos Papanastassiou filma clandestinamente as brutais conseqüências das invasões italiana, búlgara e alemã na Grécia durante a Segunda Guerra.

${ }^{95}$ Segundo a crítica, "Naufrágio em alto mar", de Ely Azeredo: "Pacific: não é Titanic, mas também faz vítimas. (...) Impossível encontrar cinema em Pacific. E muito menos ética: os incautos turistas não podiam adivinhar que sua 'liberalidade' permitiria que fossem manipulados como títeres ridículos". Publicada no jornal O Globo, caderno RioShow, em 25/08/2011.
} 
dessa produção amadora e à transformação social dos donos do olhar, o que de fato muda no âmbito dos modos de produção subjetiva em relação e em reação às imagens? Se hoje, mais do que nunca, assistimos à disseminação das câmeras em todos os âmbitos da vida social - das vigilâncias nos espaços públicos e privados exercidas sobre os indivíduos às visibilidades produzidas e acionadas pelos próprios indivíduos -, é porque está em curso não uma ruptura histórica, mas um processo de intensificação, expansão e difusão da consciência do efeito-câmera e de sua conseqüente naturalização. Isto é, está em curso uma intensificação da relação entre subjetividade e visibilidade, uma inflação do nosso desejo de reconhecimento no olhar do outro ${ }^{96}$ (esse outro também inflacionado) e uma disseminação intensiva da relação entre modos de fazer e formas de ser e de aparecer não apenas na imagem (própria ao regime da representação), mas por meio da imagem (própria ao regime performativo).

Falar em naturalização, no entanto, não significa indicar um decréscimo de "performance", mas justamente o contrário: significa que a performance está em todo lugar, que ela é imanente aos campos do trabalho, do desejo e da linguagem, e, que, portanto, em meio a uma intensa reconfiguração daquilo que modernamente entendíamos como os âmbitos público e privado (então separados e tão hoje indeterminados), a própria subjetividade se forma enquanto se performa em imagem. Como sintetiza André Brasil em seu artigo "Formas de vida na imagem: da indeterminação à inconstância" (2010), contemporaneamente, "a imagem - e o conjunto das mediações que a constitui - se torna o lugar prioritário onde se performam formas de vida".

Se, ao contrário da crença corrente em uma "exposição da intimidade", as atuais formas da subjetividade se criam como exterioridade, se constituem no ato mesmo de sua publicização, é porque, não por acaso, elas compartilham com a imagem em geral e com o cinema em particular a lógica da superfície e da exteriorização. O cinema, desde seus primórdios, vem assim materializar e contribuir para intensificar o diagnóstico foucaultiano de que a subjetividade moderna é inseparável dos dispositivos de

\footnotetext{
${ }^{96} \mathrm{O}$ estatuto do olhar do outro, e o seu papel na reconfiguração dos limites entre o público e o privado, é tema de outro artigo de Fernanda Bruno, no qual a autora pergunta: "O que se torna o olhar do outro para que ele se afigure tão atraente e seja tão requisitado?" Segundo Bruno, se na Modernidade era preciso escapar ao olhar do outro, pois esse era o olhar da lei, da interdição, da repressão, ou seja, o olhar tal qual um "superego" exercido pelas instituições disciplinares, hoje, seria preciso seduzi-lo, conquistá-lo, visando à auto-realização, já que esse olhar, outrora exterior aos sujeitos, fora internalizado na forma de um "ideal de ego". Ver BRUNO, Fernanda."Quem está olhando? Variações do público e do privado em weblogs, fotologs e reality shows". In: Contemporânea - revista de comunicação e cultura, vol.03, n.02, dezembro de 2005, PósCOM UFBA.
} 
visibilidade. O que nos leva a concluir que, se as subjetividades, assim como as imagens, se constituem como exterioridade, é porque a lógica do cinema, em princípio restrita à sala escura, migrou e se disseminou por todas as esferas da vida social. Afinal, fazendo mais uma vez ecoar o pensamento - e as grandes frases - de Jean Louis Comolli: “A mise en scène é um fato social. Talvez $o$ fato social principal” (2008:98).

Distanciando-se, portanto, do homo psychologicus moderno, que organizara sua experiência em torno do eixo de uma interioridade hipertrofiada e dos domínios profundos e recônditos da subjetividade, os dispositivos de poder e de visibilidade contemporâneos estimulam antes uma "experimentação epidérmica" (Sibilia, 2008:110), deslocando os existenciais conflitos d'alma de outrora para o território da performance (Bezerra Jr., 2002). Com isso, não significa dizer que a topologia da interioridade fora abolida - afinal, a vida social ainda é organizada em torno do espaço privado e de seus diversos níveis de vida "interior", como a casa, a família e o psiquismo $^{97}$-, mas que ela deixara de ser o foco exclusivo de investimento, cuidado e controle, assim como deixara de ser a morada mesma da verdade ou do desejo do sujeito.

Estamos aqui talvez mais próximos das "subjetividades pré-modernas" (uma contradição em termos), para as quais o espaço público, que hoje adquire outras conotações, diferentemente do moderno ideal republicano de homogeneização e apagamento de si em nome de um corpo coletivo, era na Antiguidade um espaço de diferenciação e singularização por meio da aparência (Arendt, 2005), no qual o homem político só existiria se se fizesse visível a outrem - não a um "semelhante", mas a um "diferente". Desse modo, no lugar da expressão de supostos "espontâneos" momentos de "intimidade" em família ou entre amigos, a apropriação e reescritura, pelo cinema, das imagens amadoras e dos filmes domésticos - construídos (talvez desde sempre) como exterioridade, como superfície, com a consciência do olhar alheio -, traz à tona não a publicização do "íntimo", mas produção do "êxtimo": aquilo que, segundo a psicanálise, sendo tão próprio aos sujeitos, só poderia apresentar-se fora deles, no

\footnotetext{
${ }^{97}$ É digno de nota que, sob o paradigma do "ocaso" de nossa interioridade psicológica moderna (Bezerra Jr, 2002), as neurociências e as descrições fisicalistas da vida mental ganham cada vez mais importância e mobilizam investimentos cada vez mais vultosos, cenário em que emerge o "sujeito cerebral". Para uma perspectiva crítica desse movimento de redução fisicalista da subjetividade, ver, no Brasil, artigos de Benilton BEZERRA JR, Francisco ORTEGA e Jurandir Freire COSTA (pesquisadores do Instituto de Medicina Social da UERJ), assim como de Fernando VIDAL (pesquisador do Instituto Max Planck, em Berlim).
} 
âmbito da cultura, no âmbito da interação com o outro, no âmbito da exterioridade da linguagem e dos regimes de visibilidade.

\section{Regime performativo, fim do fora?}

É certo que passamos dos dispositivos repressivos aos dispositivos produtivos, da disciplina às novas formas de controle, das vigilâncias às visibilidades, do "faça você mesmo" ao "mostre-se como for", do "saber fazer" ao "saber ser", e, cada vez mais, ao "saber parecer", em um momento histórico em que, como vimos, trabalhar é produzir-se a si mesmo e no qual as subjetividades se tornam um espaço de experimentação epidérmica nas peles e nas telas. Como verbos hoje inextrincáveis, ser e parecer, isto é, produzir-se como sujeito visível, nunca fora antes um trabalho tão incessante, tão inesgotável: como as aulas de aeróbica, as coreografias coletivas, as gincanas perversas, as festas temáticas, os dedos nos zooms e os espetáculos musicais que recobrem de verdade e simulação, autenticidade e encenação, alegria e melancolia - não sem afeto e fabulação -, a ordem do dia seguida à risca em Pacific.

Nesse perpétuo trabalho voluntário cuja moeda de troca são os valores agregados à visibilidade e ao auto-reconhecimento pela imagem, como vemos na liberdadeconfinada de Pacific, espécie, com todas as ressalvas, de "Big Brother" em alto mar filmado pelos próprios participantes (e, a princípio, para consumo próprio), fica evidente, portanto, de que modo a inflacionada experiência de si na contemporaneidade tem passado por aqueles radicais deslocamentos. Assim, se na Modernidade a experiência de si fora edificada por meio de introspectivas técnicas hermenêuticas, como cartas, diários íntimos, confissões e relatos, lidos e escritos na reclusão e na solidão de quartos privados, lá o contato com o mundo exterior dava-se pela metáfora da janela - e sua relação com o fora de quadro -, mais tarde incorporada pelo regime da representação clássica e pelo cinema clássico-narrativo.

Para que possamos compreender os deslocamentos em jogo nas passagens dos regimes representativo para o performativo, sobre os quais tanto temos dito, é preciso retomar a metáfora da janela, essa figura tão banal quanto clichê, que vem orientando diversos regimes de visibilidade (a pintura, o cinema e até a televisão) desde a Renascença, com a invenção da perspectiva e a composição, por Alberti, do quadro como "janela aberta ao mundo". Se a perspectiva forjada pelo quadro como janela impõe um novo modo de olhar e um novo modelo de conhecimento, ela também forjara 
o sujeito racionalista, cognoscente e autônomo da modernidade: um sujeito que pode ver sem ser visto; que pode dissolver-se naquilo mesmo que vê; e que pode enfim ver a si mesmo como espectador. Em suma, um sujeito que, soberano e cartesiano, toma o mundo por seu objeto - e que, separado tanto do mundo como da cena, será, com frequiência, tomado por voyeur ${ }^{98}$.

Não por acaso, a partir de uma vasta história, atravessada por diversos domínios, a janela pode ser pensada como elemento constitutivo da Modernidade, assim como modo privilegiado de subjetivação, como se a subjetividade moderna tivesse sido estrutura tal como uma janela (Wajcman, 2004). Segundo o filósofo e psicanalista Gérad Wajcman ${ }^{99}$, ao instaurar um limite entre o mundo interior, resguardado, e o mundo exterior, aberto ao olhar, a janela teria inventado o espaço da intimidade e do cultivo subjetivo - cujo deslocamento ou declínio, podemos intuir, será paralelo não apenas à reconfiguração em curso dos espaços público e privado como ao próprio deslocamento do regime representativo. Isto é, o regime da representação clássica, sustentado pelo modelo operatório da janela, pertence, do ponto de vista da perspectiva histórica, a um momento em que o espaço do íntimo e do cultivo subjetivo era garantido e resguardado pelo espaço privado. E o "drama sério burguês" postulado por Diderot no século XVIII, bem como, posteriormente, o estabelecimento do melodrama como gênero dramático no XIX virão reforçar esse espaço privado como lugar das emoções sinceras e dos sentimentos autênticos (Xavier, 2003:63).

Desse modo, não se pode falar em um dispositivo da janela sem se levar em conta o regime da representação clássica instaurado pelo cinema clássico-narrativo, herdeiro do teatro moderno e do "drama sério burguês" defendido por Diderot. Como ressalta Ismail Xavier (2003:07), a geometria do olhar e da cena não se iniciou no cinema, mas nele encontrou um ponto de cristalização de enorme poder na composição da cena como espaço autônomo e autobastante (por meio do ideal da "quarta parede") e na determinação do lugar espacial (e por conseqüência social) do espectador. Assim,

\footnotetext{
${ }^{98}$ Palavra mágica, diagnóstico pronto e explicação demasiado facilitada (se não equivocada), o conceito de voyeurismo parece dar conta da "pulsão escópica" que pauta as relações entre o olhar e a cena em nossas sociedades mediadas pela imagem. Como veremos, no âmbito de um regime performativo e interativo, o voyeurismo não tem lugar.

99 Em 2001, Gérad Wajcman protagonizou, ao lado Claude Lanzmann, uma intensa polêmica contra a representação fotográfica dos campos de extermínio nazistas apresentada em uma exposição em Paris. A defesa de Wacjman do Holocausto como evento "irrepresentável" envolveu teóricos e cineastas em um debate histórico, o qual deu origem ao importante livro de Georges Didi-Huberman, Images malgré tout (Paris: Les Éditions de Minuit, 2003).
} 
supondo um lugar calculado para esse espectador (ibid, 2003:61), a perspectiva, o palco italiano do teatro, sobretudo pós-Diderot, e o cinema clássico-narrativo farão da distância e da separação entre observador e observado, entre vida e cena, entre realidade e espetáculo, a base do regime representativo da arte.

É a partir de tal separação, condição da representação clássica, que o espectador pode enfim mergulhar no mundo de dentro da tela por meio da identificação e do "efeito janela" - efeito que, paradoxalmente, promoverá o apagamento dessa distância mediadora, assim como o apagamento do corpo do espectador. Nesse sentido, se o cinema clássico-narrativo constitui a base do regime representativo da imagem, um regime pautado por um ponto de vista estável e pela exclusão daquele que filma como condição do estabelecimento de uma perspectiva - pois, como diria a lei do perspectivismo "para que se possa ver é preciso que algo permaneça daí excluído" (Veloso, 2004:215) -, Pacific, por sua instabilidade de pontos de vista e pela permanente inclusão daquele que filma, filia-se a um regime performativo da imagem, para o qual, no âmbito da diegese fílmica, não haveria mais janela, não haveria mais fora.

Ao absorver, portanto, em sua diegese, a distância e o "antecampo", o espaço da câmera (Aumont, 2004:41), pela permanente inclusão daquele que filma própria a um regime performativo, Pacific torna evidente certa inversão: no âmbito de suas imagens (as imagens produzidas pelos passageiros do cruzeiro), não é o olhar aquilo que determina um campo de visão, é o campo que, imanente à vida social, já compreende e engendra uma variedade de olhares e multiplicidade de pontos de vista. Como se, no contexto da disseminação dessas traquitanas tecnológicas de produção de imagem e som, o olhar fosse um efeito de um dispositivo que lhe é anterior - e tanto é assim que, no limite, esses novos dispositivos digitais prescindem do olhar para filmar. Não seria sem razão supor que essa inversão é também correlata aos contemporâneos modos de produção subjetiva, quando nos é dito (por toda uma cultura terapêutica dos manuais de autoajuda e auto-gestão) que primeiro é preciso parecer, para, depois, ser-movimento próprio a uma dinâmica cultural que, definitivamente, substituiu as causas pelos efeitos.

Boa parte das imagens produzidas pelos turistas do cruzeiro Pacific não são, portanto, filmagens de paisagens ou poses de família em meio às paisagens, em que freqüentemente alguém, o sujeito que filmava ou fotografava no turismo de antanho, ficava de fora da imagem. Em Pacific, trata-se das filmagens dos próprios passageiros e por eles próprios, agora incluídos na cena, em meio a essa lógica de permanente 
inclusão na imagem daquele que filma (como no caso do jovem casal que se filma dançando no convés do navio ou do casal mais velho que se filma, em um gesto de afeto, em sua cabine). Evidentemente, a história do cinema e do documentário é atravessada por momentos (auto)reflexivos em que a câmera, algumas vezes acompanhada das próprias equipes de filmagens, é explicitada, seja por meio de reflexos indiretos em superfícies translúcidas, seja por meio de reflexos diretos em espelhos (prática freqüente em filmes-diário anteriores à chegada do vídeo, quando o cineasta não podia emancipar seu olhar do aparato), seja pela presença de uma segunda câmera (no antecampo) que filma a câmera "protagonista" como parte da própria diegese fílmica, tanto na ficção como no documentário. Ainda que de Vertov a Kiarostami, passando por Jean Rouch, Godard, Fellini e tantos expoentes do cinema moderno, as cinematografias estejam repletas de exemplos como esses, algo de extremamente significativo parece-nos estar em curso, e, se Pacific é tão desconcertante, é porque, justamente, ele simultaneamente dá a ver e engendra esses deslocamentos.

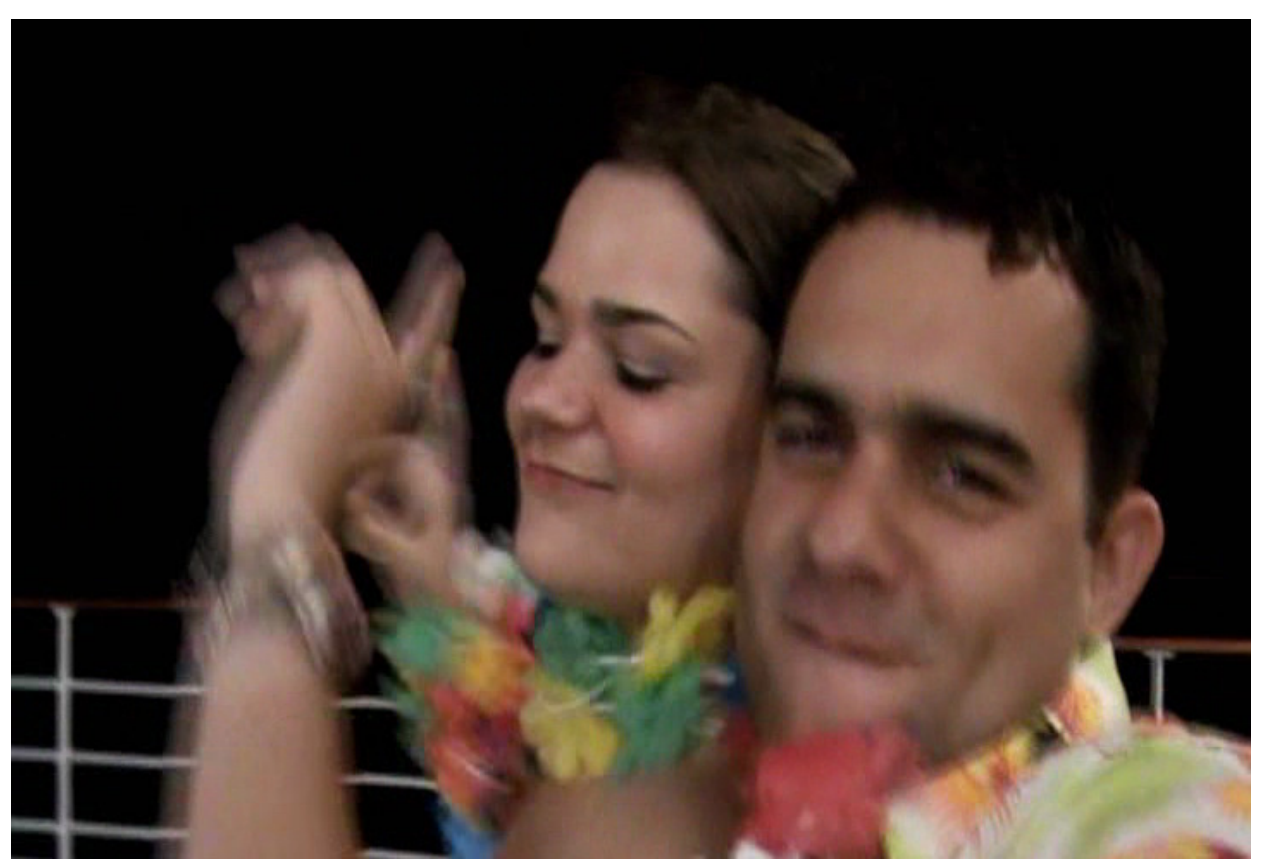




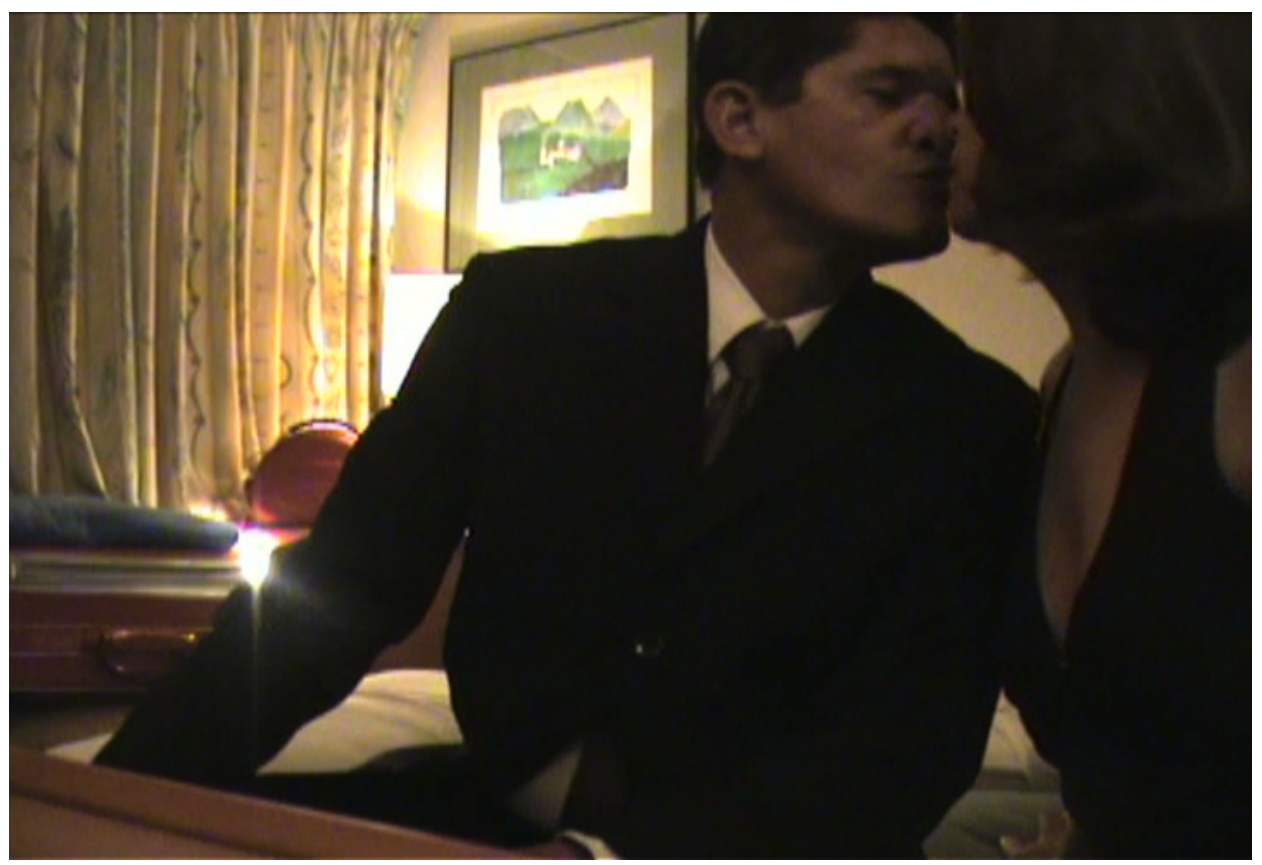

Com isso, estamos indicando, em relação às imagens amadoras, auto-referentes e performativas, a evidência do declínio de um modelo de representação clássica, baseado, como vimos, na escolha de um ponto de vista estável e fixo, na exclusão daquele que filma e na separação do espectador da cena - o qual deve se apagar para então, alheio a si próprio, se projetar no espaço da diegese fílmica. Dinâmica contrária aos regimes inclusivos e participativos contemporâneos, que, rompendo a "quarta parede", solicitam do espectador, consciente de si, seu engajamento, cumplicidade e colaboração. Importante salientar que nessa definição das posições e ocupações do espectador está em jogo o arraigado preconceito segundo o qual no regime representativo o espectador seria sempre "passivo", separado da capacidade de conhecer e da possibilidade de agir, enquanto no regime performativo, o espectador, "emancipado" da sua passividade contemplativa, seria então "ativo", "interativo" e dotado de autonomia.

Como diria provocativamente Slavoj Zizek, citado por André Brasil e Cezar Migliorin no artigo "A biopolítica do amador" (2010), a passividade do sujeito não foi contemporaneamente tornada interatividade, mas, mais precisamente, “interpassividade". Assim, para o filósofo, o impacto verdadeiramente inquietante das novas mídias digitais não residiria no fato de que elas expropriam a parte ativa de nosso ser, mas exatamente no oposto, no fato de que elas nos privam da dimensão passiva de nossas vidas: “elas são 'passivas por nós"”! (Zizek, 2006:20). 
Por isso, a perspectiva aqui adotada não implica, que fique claro, a desqualificação de um regime de visibilidade em detrimento da qualificação do outro, porque, além desses regimes serem de fato cada vez mais híbridos, nenhuma prática, nenhum protocolo formal, em si mesmo, garante mais ou menos vigor estético e potência política, mais ou menos interesse. É apenas no embate com as obras que podemos perceber o que de fato está em jogo na dinâmica da representação clássica (pautada pela separação) ou na dinâmica do regime performativo (pautada pela inclusão). Cabe lembrar também que esse modelo da representação tem sido questionado, pelo menos, desde fins do século $\mathrm{XIX}^{100}$, mas agora trata-se de uma prática, que engendra outras formas de olhar, de ser e de aparecer no mundo, completamente difusa e socialmente ramificada, a partir da difusão e popularização das tecnologias digitais de produção de imagem e som, mas também, e sobretudo, das cada vez mais ardilosas e "democratizadas" estratégias de colaboração, participação e inclusão $^{101}$.

\section{Um filme de}

De formas bastante distintas, outros filmes como Rua de mão dupla (Cao Guimarães, 2004), Avenida Brasília Formosa (Gabriel Mascaro, 2010) e Viajo porque preciso, volto porque te amo (Marcelo Gomes e Karim Ainouz, 2009), naquele movimento entre uma "etnografia discreta" e uma auto-etnografia, vão trabalhar a partir dessa dimensão inclusiva própria ao regime performativo, mas deslocando-a de seus usos midiáticos e cinematográficos mais repisados. Nesses filmes, não se trata de simplesmente incorporar imagens dos outros e imagens outras, mas de engendrar dispositivos de criação, protocolos formais, por meio dos quais o cineasta possa escapar

\footnotetext{
${ }^{100}$ No que diz respeito aos diversos dispositivos óticos criados no âmbito das ciências em fins do século XIX e popularizados como entretenimento nas grandes feiras européias, o estereoscópio fora paradigmático por produzir um efeito de tridimensionalidade a partir da síntese corporal e assim desestabilizar a fusão binocular: garantidora da estabilidade da representação. Sobre a "modernização da percepção" nesse momento histórico, ver: CRARY, Jonathan. Techniques of the Observer. Cambridge/Massachusetts: MIT Press, 1990.

101 Não por acaso, a ficção "tradicional" tem sabido dialogar com essa demanda "participativa", simulando os efeitos da inclusão daquele que filma - como vemos desde o paradigmático A Bruxa de Blair (Daniel Myrick e Eduardo Sánchez, EUA, 1999), passando pelo filme-catástrofe Cloverfield (Matt Reeves, EUA, 2008), ao filme de terror REC (Jaume Balagueró e Paco Plaza, ES, 2007) -, como se o cinema quisesse, ao simular um efeito de ausência do "antecampo" (por meio da simulação de uma câmera subjetiva), apagar a enunciação no momento mesmo da sua máxima legitimação. Assim, o campo parece sem fim... A diferença fundamental em relação à apropriação e ao deslocamento das imagens domésticas em Pacific é que, no filme de Pedroso, as pessoas que (se) filmam são o fim mesmo dessas imagens.
} 
da disseminada e banalizada prática da entrevista como forma de inclusão, na cena documental, da palavra do outro. A entrevista, de acordo com a contundente crítica de Jean-Claude Bernardet (2003:281), teria virado um "cacoete" da produção documental brasileira de início dos anos 2000, tornando-se um recurso movido pelo automatismo e pelo empobrecimento das possibilidades dramatúrgicas e observacionais do documentário. Documentário esse que então seria pautado pela predominância do verbal e pela inflação do espaço narcísico do cineasta, como se o realizador fosse o centro gravitacional de todas as relações forjadas pelo filme, "pois é para esse centro que se dirige o olhar do entrevistado" (ibid, 2003:286).

Nesse movimento que não lança mão (ao menos de forma tradicional) da entrevista, mas também não deixa de se filiar à tradição do documentário brasileiro moderno de "dar voz ao outro", trata-se de criar estratégias de partilha, de desestabilização ou de recolhimento da enunciação, em uma espécie de "retirada estética" do realizador. Para tanto, a invenção de dispositivos, por meio dos quais o realizador cria regras e protocolos formais bastante rígidos, vai permitir que o filme recuse (ao menos no âmbito da diegese fílmica) a interação entre realizador e personagens, para privilegiar as relações e interações entre eles. Almejando certo “descontrole programado" que a estratégia do dispositivo permite, o trabalho do realizador consiste então em criar uma situação inicial e organizá-la na montagem, não interferindo naquilo que acontece entre uma instância e outra. Vê-se assim um movimento bastante instigante (que não deixa de suscitar problemas e inquietações) de recolhimento da enunciação do filme para que possa haver, do modo mais efetivo possível, a inclusão dos enunciados dos personagens.

Tal é o caso do filme Rua de mão dupla, de Cao Guimarães, concebido originalmente como uma vídeoinstalação para $25^{\mathrm{a}}$ Bienal de São Paulo (flerte entre o documentário e as artes contemporâneas recorrente na obra do realizador) em que se cria o seguinte dispositivo: seis indivíduos que não se conhecem, pertencentes a uma classe média heterogênea e organizados em três duplas, trocam de casa por um período de 24 horas munidos de uma câmera de vídeo que recebem da produção do filme ${ }^{102}$. O

102 O gesto de delegar a câmera ao outro, personagem do documentário, não é recente em nossa cinematografia, como ocorre em Jardim Nova Bahia (Aloysio Raulino, 1971), no qual as imagens filmadas pelo personagem principal foram montadas "sem qualquer interferência do realizador", como informam os créditos iniciais do filme. A esse respeito ver "A voz do outro". In: BERNARDET, JeanClaude. Cineastas e imagens do povo. Companhia das Letras, 2003, p.119. Importante notar que, de lá pra cá, tal gesto começou a ser largamente difundido a partir das oficinas de vídeos e dos projetos sociais de 
objetivo é que cada um deles, por meio das imagens captadas, tenha total liberdade para organizar uma imagem do outro, conferir-lhe uma identidade, a partir das evidências e dos vestígios encontrados (pertences e objetos pessoais, modo de organizar a casa, preferências literárias e futebolísticas etc.). A partir daí, o documentário é composto exclusivamente pelas imagens produzidas por esses personagens (em sua quase totalidade tremidas, instáveis e protagonizadas pelo dedo no zoom $^{103}$ ), as quais são mostradas por pares e simultaneamente, na tela divida ao meio. Ao final, com a tela sempre divida, cada um deles constrói (para uma câmera fixa) um, literalmente, "retrato falado" do outro, o dono da casa, enquanto esse outro, na outra metade da tela (também em câmera fixa), assiste à cena em silêncio.

Por meio dessa experiência pautada pelo estranhamento e pelo deciframento, é notável como cada um deles, ao tentar decifrar o outro, ao tentar se aproximar desse estranho distante - tanto por aquilo que eles escolhem filmar quanto por aquilo que eles decidem falar -, projeta nessa alteridade traços de sua própria personalidade. Nesse trânsito cruzado, nessa rua de mão dupla, entre olhar e ser olhado, entre presença e ausência, o "retratista" se implica na imagem construída do "retratado". Se, como se costuma dizer, "toda crítica é uma autobiografia", é porque a leitura crítica que cada um faz do outro a partir desses vestígios materiais revela muito de seus próprios preconceitos, critérios de avaliação e julgamento, modos de "leitura" do mundo, desejos de coerência e atitudes de suspeita em relação às evidências.

Nesse sentido, um dos momentos mais interessantes do experimento é quando a dupla Eliana e Roberto, ela escritora e professora universitária, ele um poeta meio "marginal", depois de ter vivido a dinâmica da troca de casa, comenta sua experiência. Eliane, sempre muito segura de si, não consegue organizar uma imagem coerente desse outro, pois, como ela mesma elucida depois de chegar à conclusão de que se trata de alguém do sexo masculino, "ele é um personagem contraditório", "estranho", cuja casa revela "rastros de muita ambigüidade". Eliane, tão lúcida e bem articulada, tem dificuldade de lidar com as incoerências e ambigüidades da realidade, das pistas que despistam, das evidências opacas. Apoiada sobre uma parede branca desprovida de

formação audiovisual que tiveram início a partir dos anos 80, como o "Vídeo nas Aldeias", projeto precursor na área de produção audiovisual indígena no Brasil.

${ }^{103} \mathrm{O}$ dedo no zoom, como que um zoom ansioso e hiperativo, é uma constante tanto Rua de mão dupla como em Pacific e não deve ser reduzido a mero "amadorismo" (no sentido pejorativo) de quem filma. Em Rua de mão dupla, esse zoom-in manifesta a urgência em se aproximar do outro, em decifrá-lo, conhecê-lo, enquanto em Pacific ele expressa a urgência do desfrute da viagem, como se a redução da distância implicada por esse movimento de câmera intensificasse e "aumentasse" a experiência. 
qualquer inscrição, ela gostaria de poder organizar um "personagem clássico", enquanto Roberto, como "personagem moderno", sempre escapa a seu poder de análise. Já quando chega o momento de Roberto comentar sua própria experiência, sentado na aconchegante sala de estar de Eliane, o poeta abre mão da análise em favor da expressão de sua comoção: ele está ali, como um estrangeiro acolhido pelo outro, estupefato diante do que significa partilhar a "intimidade" dessa alteridade. "Quem ela seria?", ele se pergunta diversas vezes. "Quem somos?

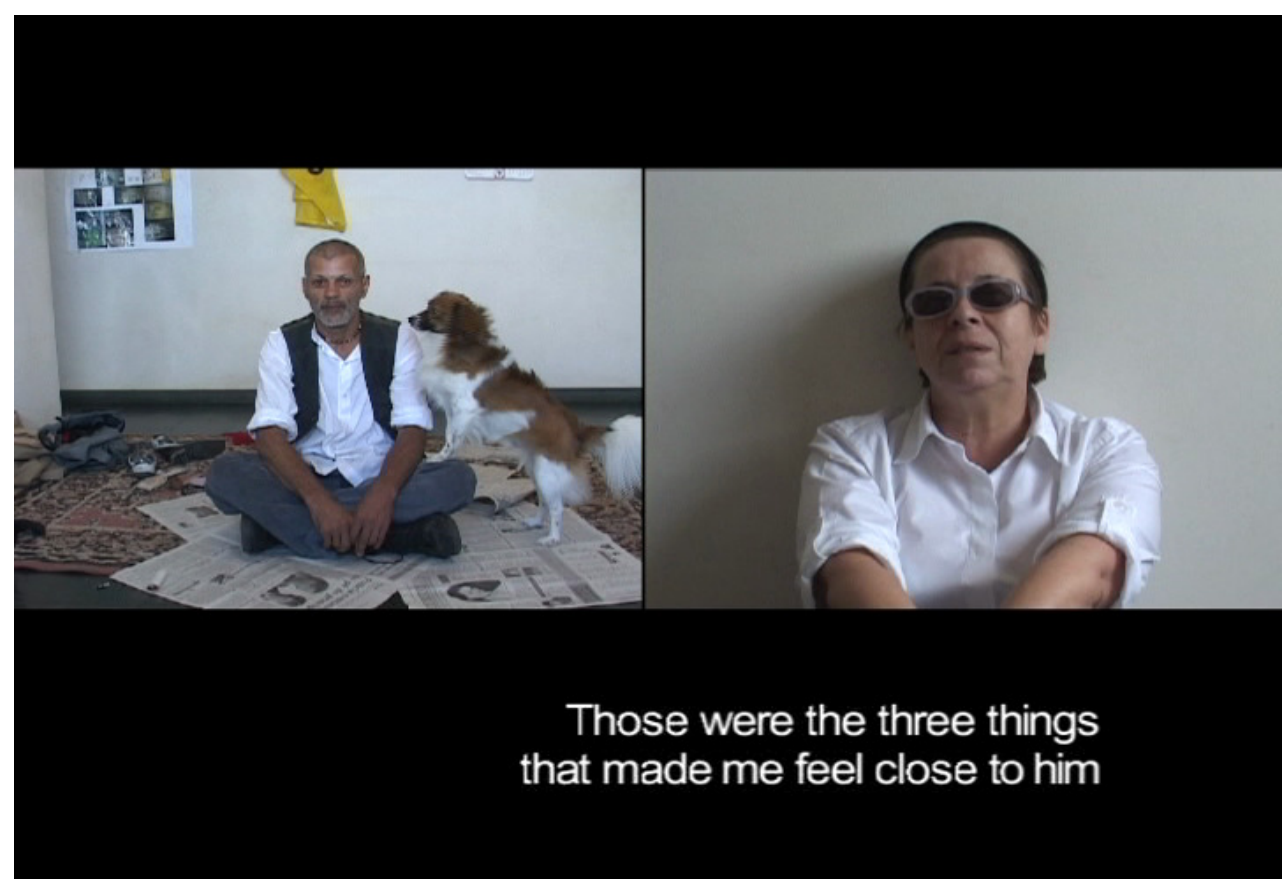

Nessa dialógica construção de si por meio do outro e do outro por meio de si, Rua de mão dupla parece materializar o belo dizer de Jean-Louis Comolli (2004) em relação ao documentário: "Não pensar o outro, mas pensar que o outro me pensa". O artifício da tela dividia ao meio não é, portanto, mero formalismo. A separação que essa divisão instaura é a condição mesma da relação possível, uma relação que não aconteceria sem o dispositivo do filme, ou seja, que o próprio filme produz e performa, no âmbito da imagem, mas também da vida. É a partir de tal separação que Rua de mão dupla pode também restituir ao regime performativo da imagem uma dimensão que lhe é tão rara: a dimensão da solidão. Mas, ao contrário dos solitários voyeurs tão característicos do regime da representação clássica que desaguou no cinema, caso 
célebre de Janela indiscreta (Alfred Hitchcock, 1954) ${ }^{104}$, aqui o observador não está separado dos objetos observados por meio de uma janela; aqui o observador não precisa se esconder para melhor ver. De modo o contrário, o "voyeur" de outrora adentrou a casa ou a cena do outro, com seu consentimento, e a observa desde dentro - e não mais de fora.

É por essa razão que no âmbito de um regime performativo e interativo, pautado pelo voluntarismo e pelo "pacto de encenação" entre observadores e observados, entre o eu e o outro, o voyeurismo não tem lugar, pois não se trata mais de uma observação sem consentimento (tal como uma imagem roubada) e a partir de um único e estável ângulo (a clássica figura da janela ou da fechadura). Não se trata mais, portanto, de observar furtivamente, à distância e na reclusão, mas de tornar explícito e transparente o modo como opera esse olhar, o modo como "espiar" (ao contrário de um gesto a ser reprimido) se tornou hoje um "direito" a ser exercido. Em um momento histórico em que o formato narrativo dos reality shows tornou-se um dispositivo biopolítico (Feldman, 2008) de gestão e instrumentalização da vida, disseminado por todos os âmbitos e recantos do globo terrestre, do ocidente ao oriente, diz o bordão do apresentador do Big Brother Brasil, Pedro Bial: "Vamos exercer nosso direito de espiar!".

Porém, se Rua de mão dupla, assim como Pacific, dialogam com os efeitos dessa cultura audiovisual midiática (e Rua de mão dupla, enquanto premissa, não estaria distante daqueles reality shows em que os participantes trocam de casa, como "Minha casa, sua casa" e congêneres), eles certamente, e astutamente, escapam de suas armadilhas. A mesma relação transversal, de mútua contaminação e resistência, ocorre com Avenida Brasília Formosa, de Gabriel Mascaro (2010), construído a partir de um rigoroso dispositivo observacional e destituído de qualquer interação entre o realizador e seus personagens. Não por acaso, essa espécie de "recusa" da interação entre realizador e personagens (para assim priorizar as relações entre eles), bem como o privilégio de universos sociais de classe média ou de classe baixa emergente (para os quais o consumo ou as posses está em questão), determinam os projetos de Pacific, Rua de mão dupla e Avenida Brasília Formosa - o que não deixa de nos parecer uma resposta às críticas de Jean Claude Bernardet endereçadas tanto ao abuso da entrevista

\footnotetext{
${ }^{104}$ Sobre o paradigmático filme de Hitchcock, ver o capítulo "O lugar do crime: a noção clássica de representação e a teoria do espetáculo, de Griffith a Hitchcock”. In: XAVIER, Ismail. O olhar e a cena Melodrama, Hollywood, Cinema Novo, Nelson Rodrigues. São Paulo: Cosac\&Naify, 2003.
} 
quanto ao predomínio do "outro de classe", a figura dos vitimizados e excluídos, no cenário do documentário brasileiro de início dos anos 2000.

Trabalhando assim com um universo não de classe média, mas de uma "classe $\mathrm{C}$ emergente", que durante a Era Lula acedeu ao consumo em meio a uma situação de moradia ainda precária, Mascaro aborda sutilmente os desdobramentos da construção da Avenida Brasília Formosa na vida daqueles que moram na favela de Brasília Teimosa, na cidade do Recife. Para tanto, adota um ambíguo dispositivo de não-interferência entre o acompanhamento dos personagens e a encenação das situações por eles vividas, criando um efeito de distanciamento em relação ao universo filmado, universo que então seria, como a cena "clássica" da ficção, dotado de autonomia. Nesse movimento, sustentado, de um lado, por um notável rigor dos enquadramentos e das composições visuais, e, de outro, por difusas relações entre os personagens, as quais se dão como que por "contágio", o filme se avizinha de uma dinâmica de rarefação dramatúrgica bastante recorrente no documentário brasileiro contemporâneo ${ }^{105}$, porém trazendo outros elementos e formas de inclusão, não simplesmente inclusão da imagem dos outros, mas das experiências dos outros com a imagem.

Com isso, ao optar por uma enunciação recolhida, Avenida Brasília Formosa, por meio desse recolhimento, incorpora e inclui, em sua urdidura narrativa, imagens produzidas (ou supostamente produzidas) por seus próprios personagens, em um desconcertante deslocamento de materiais fetichizados ${ }^{106}$, culturalmente pré-formados: como o vídeo de aniversário do menino Cauan, que completa cinco anos; o videobook da manicure Débora, que está pleiteando uma vaga no reality Big Brother Brasil; algumas imagens de telejornais (gravadas em fita VHS por um dos personagens) a

105 O que chamamos aqui de "documentário" brasileiro contemporâneo é uma produção bastante híbrida, cujos protocolos documentais (o trabalho com não-atores ou atores-amadores em seus ambientes reais) são atravessados por recursos expressivos da ficção (a reencenação e a decupagem das situações, a montagem narrativa, por vezes o uso de trilha sonora não-diegética etc.). Algumas das características dessa produção (para além de sua, em menor ou maior medida, inspiração bressoniana) são a rarefação da dramaturgia, desprovida da figura do "antagonista"; a atenuação das "determinantes", sociais ou econômicas, que então deixam de determinar o destino dos personagens; e a composição de personagens a partir de suas "experiências", os quais se relacionam entre si e com o mundo por meio de conexões mais difusas, fugidias, na chave de um registro "poético", isto é, de intensa expressividade estética.

${ }^{106}$ No curta-metragem As aventuras de Paulo Bruscky (2010), Gabriel Mascaro radicaliza esse uso de materiais fetichizados e realiza um "documentário" sobre o artista Paulo Bruscky feito exclusivamente com imagens da plataforma de realidade virtual Second Life, que não deixam de ser um "documento" de certo regime de visibilidade contemporâneo. No Second Life, um avatar do artista se engaja em aventuras “extremas", as quais são acompanhadas pelo avatar do então diretor de cinema Gabriel Mascaro, que está registrando essas aventuras para o tal documentário a que estamos assistindo. Tem-se aí talvez o exemplo mais radical desse movimento de inclusão absoluta da enunciação do filme "dentro" do próprio filme, isto é, da fusão e indeterminação entre enunciados e enunciação. 
respeito da visita do então presidente Lula em 2003 à Brasília Teimosa, no momento de remoção das palafitas e antes da construção da Avenida; e mesmo trechos de um videogame (desses acionados pelos aeróbicos movimentos do corpo todo) jogado pelos personagens.

Essa produção, evidentemente mobilizada pelo filme, gira em torno do personagem Fabio, garçom que, nas horas vagas e entre outros bicos, trabalha como cinegrafista "amador" prestando serviços à comunidade: faz e edita, em seu computador, vídeos de casamento, de aniversário, vídeo para Big Brother e o que mais lhe for pedido. Assim, entre a "etnografia" dessa comunidade (com seus modos de vida, sua circulação pela cidade, suas formas de trabalho, de desejo e de linguagem) e uma "auto-etnografia" dos personagens (indissociável das imagens "por eles" produzidas e consumidas), Avenida Brasília Formosa se abre a variados atravessamentos e contaminações com esses performativos regimes de visibilidade, em que as formas de vida, ainda que forjadas e ficcionalizadas pelo filme e no filme, se formam e performam para a imagem, na imagem.

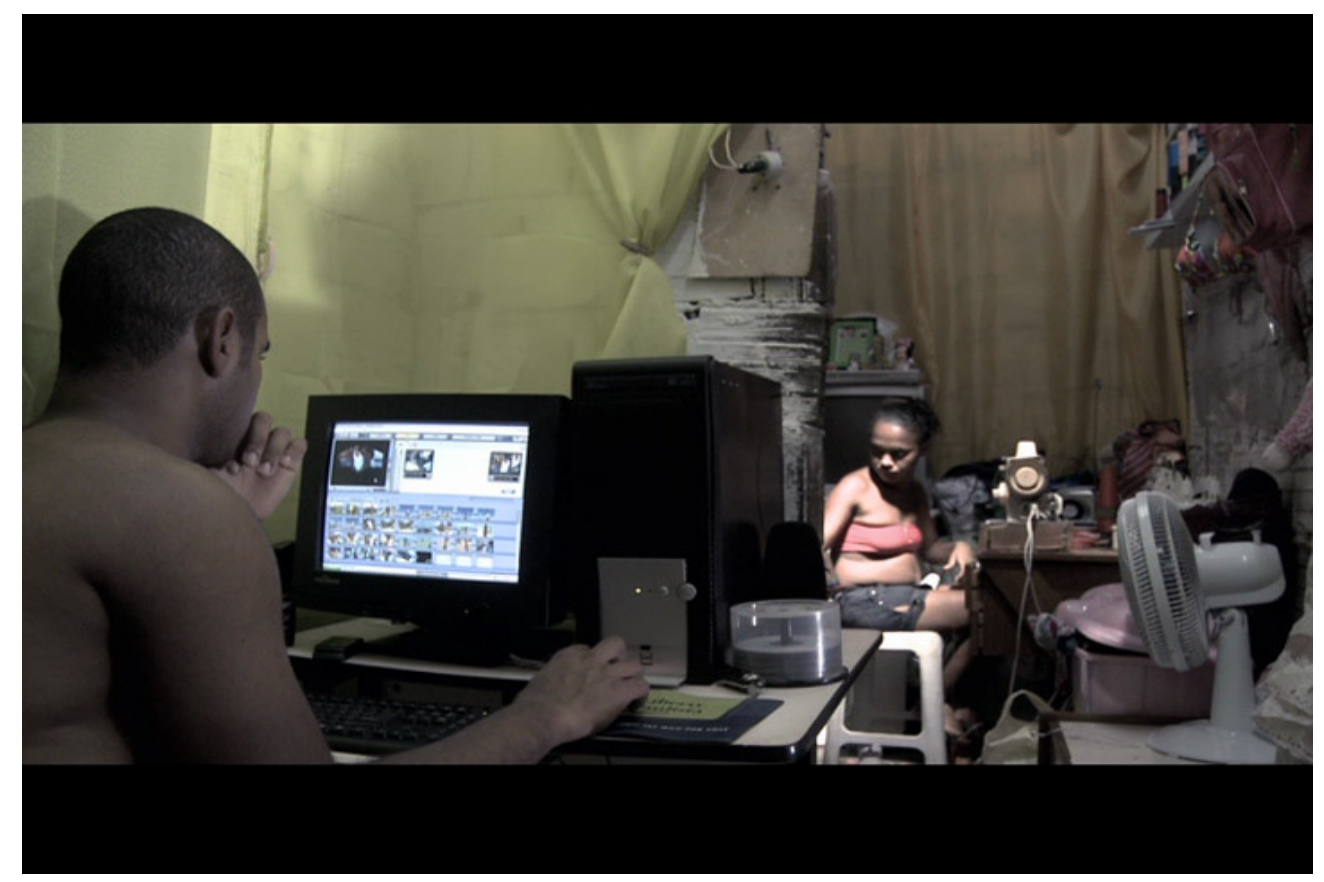

Tão aparentemente diverso desse movimento apontado por Rua de mão dupla e Avenida Brasília Formosa, Viajo porque preciso, volto porque te amo, de Marcelo Gomes e Karim Ainouz (2009), é um filme explicitamente ficcional, porém construído e costurado a partir de imagens documentais e "amadoras", captadas ao longo de dez anos em diversas viagens ao sertão nordestino feitas pela dupla de diretores. Marcelo Gomes 
e Karim Ainouz organizam narrativa e ficcionalmente esse material captado em suportes distintos (como vídeo, filme Super 8 e fotografias) e não originalmente produzido para o filme em questão, em um processo de recontextualização e reapropriação dessas imagens de "arquivo". Para tanto, constroem uma narração na primeira pessoa do singular, situada na voz corporificada do protagonista José Renato, um geólogo que, acompanhando as obras de transposição do Rio São Francisco, atravessa, sozinho, o sertão do país, enquanto remói as saudades da mulher deixada.

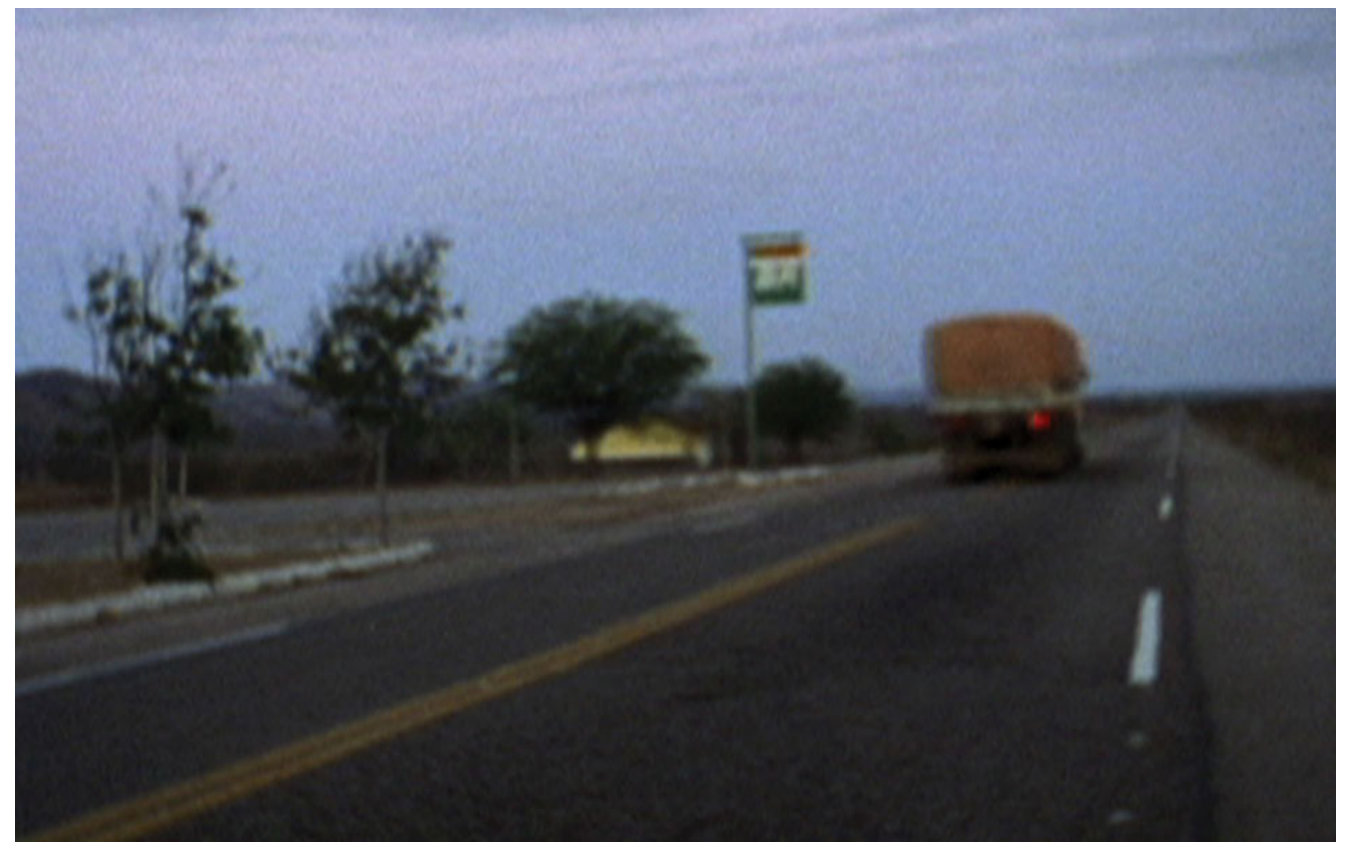

Se José Renato está presente na cena apenas como voz, desprovido de corpo e de rosto, é porque o filme faz coincidir a narração em primeira pessoa com o ponto de vista subjetivo da câmera "do personagem". Dirigindo seu carro pelas estradas (apesar de não vermos o veículo), José Renato dedica-se a um monólogo interior: comenta paisagens, rememora seu passado amoroso do qual parece tentar se recuperar, tece considerações sobre as condições geológicas da região e sobre seus instrumentos de trabalho, e, de forma ainda mais interessante, analisa algumas cenas, retendo o fluxo das imagens em favor de pequenas paradas, efêmeras interações - dotadas de um forte efeito de presença documental - com moradores das regiões por quais passa.

Em dado momento, a voz de José Renato interfere na imagem, pois ele não quer filmar um casal de idade separado, já que afinal eles passaram toda a vida juntos, e pede que Seu Nino retorne à cena, para assim ficar ao lado de Dona Perpétua, sua companheira de estrada. Em outro, após passar por Juazeiro, a cidade dos romeiros, 
deixar um pedido na "sala dos milagres" e se envolver com prostitutas ao longo do percurso, a voz de José Renato chega mesmo a "entrevistar" a prostituta Patrícia, que diz que seu sonho é ter uma "vida-lazer", “um amor assim reservado só pra mim”, entre outras passageiras interações entre aquele que está de passagem e aqueles para quem a vida passa morosamente.

Novamente, por caminhos diversos, entre uma "etnografia discreta" da região do sertão e a "auto-etnografia" daquele que narra a si mesmo reflexivamente, problematizado sua relação com o passado por meio do deslocamento e da interação com os outros, Viajo porque preciso, volto porque te amo se estrutura a partir da inclusão da voz daquele que filma, isto é, a partir da fusão da enunciação do filme com os enunciados de José Renato. Entre o roadmovie (gênero moderno pautado por uma jornada de transformação e superação de si a partir do deslocamento geográfico) e o travelogue (filme de viagem, muito popular nos primórdios do cinema, baseado na exposição de fragmentos de lugares distantes e narrados pelo explorador-viajante), Viajo parte da dissociação entre som e imagem, tão explorada pelo cinema moderno, mas acomoda essa relação, no sentido de que o desenrolar das dores e amores do protagonista (em sua jornada de autossuperação) se orienta por uma progressão dramática classicamente organizada.

Como ocorre com a estrutura narrativa de Pacific, em que as experiências dos personagens, vividas coletivamente no navio, vão se acumulando em uma espécie de presente contínuo, Viajo também possui uma estrutura bastante clássica, porém articulada por uma narração em primeira pessoa que faz emergir a memória a partir do presente (já tornado passado) de suas imagens. Em ambos os casos sustentadas pela reapropriação ou recontextualização de materiais heterogêneos e pré-formados, as estruturas narrativas de Pacific e Viajo filiam-se então a um moderno hibridismo. A diferença é que, em Viajo porque preciso, volto porque te amo, José Renato, solitário no ensimesmamento de seu veículo, dedica-se a uma viagem auto-exploratória (entre o ressentimento inicial e a afirmativa autossuperação final), em uma coincidência entre o que o personagem conhece de si mesmo e o que o filme faz conhecer de seu personagem.

Já em Pacific, aquele que enuncia, o realizador, mesmo na condição de “etnógrafo", não possui mais o privilégio do saber, tendo de assumir a posição frágil de quem pouco sabe sobre o outro. A problematização do lugar de quem enuncia é então levada ao extremo e, como já chamava atenção Cezar Migliorin em sua crítica a muitos 
documentários brasileiros contemporâneos anteriores a Pacific, "o outrora tradicional papel social do documentário - dar voz ao outro, fazer falar o excluído, reivindicar direitos - entra em crise dentro da mesma crítica à possibilidade de o documentário enunciar a partir de um lugar estável" (2009:251). Porém, se no âmbito do documentário brasileiro contemporâneo esse movimento de desestabilização da enunciação pode ser bastante problemático - pois se partilha o espaço de criação, mas também se transfere para o dispositivo as responsabilidades e conseqüências de suas invenções -, é preciso notar que essas estratégias também respondem àquele momento histórico no qual o cineasta era dotado de um mandato popular para falar pelo outro (e não simplesmente "dar voz ao outro") e assim ser o dono da voz.

Cabe salientar que essa crise ou desestabilização da enunciação não significa, de modo algum, uma crise da "autoria", como se o diretor não estivesse presente. De modo contrário, no caso de Pacific há pelo menos três mise en scènes perceptíveis: a mise en scène montada pelo cruzeiro; a mise en scène produzida pelos próprios passageirospersonagens e a mise en scène operada pelo filme, pois afinal montar é pôr em cena, é dar a ver no instante mesmo em que é esconder - ou se esconder. $\mathrm{O}$ autor, portanto, não poderia desaparecer, pois, como já dizia Foucault (2003), a autoria é desde sempre a singularidade de uma ausência ${ }^{107}$. O que fazem esses filmes todos é talvez tornar explícito esse efeito de ausência enunciativa, espécie de "vazio" que constitui a própria mediação, a própria distância, entre o gesto do cineasta e as imagens com as quais ele trabalha; entre o filme e o mundo.

Entretanto, é bastante inquietante o fato de que essa enunciação partilhada, recolhida, desestabilizada ou em crise não deixa de ser, no campo político, também sintomática de um movimento de "transferência de responsabilidade", percebido nas mais diversas formas de organização social e econômica, como nas dinâmicas das famílias e das instituições públicas e privadas. Um pouco como a divisão dos lucros mas também dos prejuízos - pelas empresas mais "avançadas" do capitalismo contemporâneo, quando seus trabalhadores não são mais contratados sob as regras das legislações trabalhistas (como aquela massa sem nome das "pessoas físicas" que

${ }^{107}$ Retomando a conferência de Michel Foucault, "O que é um autor?", Giorgio Agamben formula em relação ao texto uma problemática que poderia ser estendida ao cinema: "O autor não está morto, mas pôr-se como autor significa ocupar o lugar de um morto. Existe um sujeito-autor e, no entanto, ele se atesta unicamente por meio dos sinais de sua ausência. Mas de que maneira uma ausência pode ser singular? (...) Se chamarmos de gesto o que continua inexpresso em cada ato de expressão, poderíamos afirmar que o autor está presente no texto apenas em um gesto, que possibilita a expressão na mesma medida em que nela instala um vazio central." Ver AGAMBEN, Giorgio. "O autor como gesto". In: Profanações. São Paulo: Boitempo, 2007. 
constituíam propriamente "os outros"), mas agora como "parceiros", "colaboradores", "comunidade" de diferenciadas "pessoas jurídicas" incluídas no jogo. Assim, em um momento de crise, seja política ou econômica, institucional ou familiar, como estão todos no mesmo barco, ninguém pode tomar pra si a responsabilidade.

Tal lógica faz-se também freqüentemente presente na apropriação das imagens amadoras (dos vídeos-flagrantes e das imagens de vigilância à colaboração dos cinegrafistas amadores, hoje, "qualquer um"108) pelas empresas de comunicação, que as incorporam como forma de legitimação de seus conteúdos, asseveração de seu alcance e, no limite, de desresponsabilização - afinal é sempre mais cômodo, e sem dúvida muito mais rentável, trabalhar com essa espécie de "terceirização" não-remunerada da produção noticiosa. Dessa forma, seja porque os cinegrafistas-amadores chegam primeiro a locais que se tornam de difícil acesso às equipes profissionais, seja porque "testemunham" por meio de suas câmeras, filmadoras ou fotográficas, e de suas imagens, captadas ou construídas como "flagras", o que fica claro é que, cada vez mais, o jornalismo precisa ser avalizado e autenticado pelos efeitos de real e de verdade conferidos por imagens "selvagens" e "precárias" - ainda que haja um apurado senso estético em muitos desses enquadramentos.

Oferecidas aos grandes portais de notícias, a custo zero para as empresas de comunicação, não seria exagero considerar que as imagens amadoras, nesse contexto, além de funcionarem como "atestados de autenticidade" e "selos de responsabilidade social", operam como uma espécie de "mais-valia" da relação entre espectador e emissor. O espectador, agora um "participador", emprega, portanto, sua mão de obra, presteza e talento em troca de alguns segundos de visibilidade (quiçá, cívico reconhecimento): o mais imaterial dos pagamentos. Desse modo, em meio a essa intensa reconfiguração das "partilhas da enunciação", os tradicionais centros emissores

\footnotetext{
${ }^{108}$ Os vídeos colaborativos produzidos durante as enchentes que devastaram o estado do Rio de Janeiro em março e abril de 2010 foram, para a mídia brasileira, um evento paradigmático, um marco da incorporação desse "fluxo fluvial" da produção amadora pelas empresas de comunicação tradicionais. Na época, o Jornal Nacional, da TV Globo, chegou a ter uma de suas edições com seu conteúdo praticamente todo provido pelo trabalho dos amadores, já que as equipes de reportagem não chegavam aos lugares inundados, muito menos em tempo hábil. Já na mídia estrangeira, esse movimento de intensificação da colaboração também vem acontecendo há pelo menos uma década, desde os atentados de 11 de Setembro, mas, desde então, as imagens desautorizadas que "testemunham" a morte de governantes e líderes tiranos, como Saddam Hussein, Muammar Gaddafi, Osama Bin Laden, entre outros ainda por vir, têm sido produzidas, circuladas e consumidas como prova de verdade para uns e troféu político para outros. Sem dúvida, em meio a diversas disputas (políticas, econômicas e simbólicas), o papel político dos cinegrafistas amadores (e muitas vezes clandestinos) tem sido crescente, sobretudo no contexto de países fechados, como a Síria, em meio às revoluções (a chamada "Primavera Árabe) que têm convulsionado os países do norte da África e Oriente Médio.
} 
das informações e das imagens tornam-se menos produtores do que mediadores, articulares da disseminação "viral" dessa produção amadora. Com isso, a lógica do lucro e do acúmulo capitalista evidentemente permanece, mas o centro passar a atuar acentradamente (como uma espécie de "fora"?), gerindo a desordem do fluxo das imagens e prometendo conectar as pessoas "diretamente" (em mais uma das promessas de apagamento das mediações), no contexto do que também poderia ser chamado de um "capitalismo conexionista" (Boltanski; Chiapello, 2009).

No entanto, é preciso ter em vista que essas mesmas forças acentradas e desordenadas dos "quaisquer um" e de "todo mundo" têm feito do anonimato, e a partir dos coletivos de produção audiovisual, filmes de grande interesse, caso do longametragem Fragmentos de uma revolução (Anonymous, França, 2010) ${ }^{109}$, em que anônimos cidadãos iranianos (membros desse coletivo) tomam para si o papel de decifrar os rumos da política iraniana, burlando a censura oficial imposta pelo governo de Mahmoud Ahmadinejad. Para isso, produzem as imagens do filme assim como se apropriam de vídeos de manifestações populares, disponibilizados no Youtube por outros anônimos, e de imagens dos telejornais da televisão. Mas a estrutura narrativa da obra é mais complexa, e uma das instâncias enunciativas que se encontra em Paris, por meio de uma epistolar troca de emails com alguém que está em Teerã, tenta compreender e reconstituir o caos das imagens e dos acontecimentos políticos a partir dos links para os vídeos disponíveis na internet que ela recebe, e que então tomam parte da narrativa. Em algum momento, essa "voz", sem nome e sem rosto, reflete em uma de suas mensagens: "é como encarar um enorme quebra-cabeça com partes faltando".

A mesma tentativa de compreensão, decifração e, sobretudo, análise das imagens, é vista em Videogramas de uma revolução, um dos mais notáveis filmes de Harum Farocki com Andrei Ujica (Romênia/Alemanha, 1992), sobre o acompanhamento do processo da queda do ditador romeno Nicolae Ceausescu, que, após intensa revolta popular, é executado em dezembro de 1989. Por meio da apropriação de uma vasta gama de imagens de arquivo - fragmentos da mídia e imagens amadoras, captadas clandestinamente, da multidão em convulsão -, Farocki e Ujica mostram que, se a política se apresenta como uma questão de visibilidade, a história se faz de imagens e em imagens, mas imagens pilhadas, deslocadas, partilhadas e remontadas. Assim, se nesse trabalho por meio das imagens e sobre as imagens, "a

\footnotetext{
${ }^{109}$ No Brasil, Fragmentos de uma revolução recebeu o prêmio de Melhor Filme da Mostra Competitiva Internacional do festival forumdoc.bh, realizado em Belo Horizonte, dez., 2011.
} 
revolução seria o momento de defasagem entre uma imagem do mundo e outra imagem do mundo em vias de se criar" (Brasil, 2008), é porque fazer a revolução, por meio do cinema, é parar o fluxo da imagem, desmontá-la, remontá-la, articulá-la a outras imagens, partilhar sua enunciação, resistir a sua imediaticidade, enfim, repor a distância e a separação - e dessa forma encontrar, na imanência das imagens e na urgência da obra, uma espécie de fora.

\section{Do fim do fora ao fora como fim}

Retomando Pacific, é preciso salientar que, mesmo operando em um regime performativo e inclusivo - no qual a performance seria esse movimento de inclusão permanente, de indistinção entre o "dentro" e o "fora" -, a apropriação e reescritura das imagens de "arquivo" pelo filme faz a permanente passagem da lógica inclusiva e acumulativa do espetáculo (e mesmo da lógica acumulativa dos arquivos) à lógica subtrativa do cinema, porém sem nunca substituir uma pela outra. Como argumenta Comolli (2008:137), herdeiro tanto das feiras de variedades quanto da fotografia, o cinema sempre teve de se haver com a contradição entre o excesso dos estímulos e a restrição imposta pelo enquadramento fotográfico, entre o acúmulo arbitrário e a subtração do recorte implicada em toda escritura - mesmo que esses "recortes" sejam, no âmbito de um regime performativo, multiplicados, indeterminados. Assim, como tanto insiste Comolli, é sempre importante lembrar que ver é, de saída, um jogo obliterado pelo "não-ver". O visível não o é inteiramente (nem mesmo, ou muito menos, no âmbito disso que genericamente chamamos de "espetáculo").

Sendo assim, queremos dizer, um tanto tautologicamente, que, se Pacific pode ser filiado a esse regime performativo da imagem - dada a entronização e hipertrofia do olhar daqueles que filmam, dada sua dimensão inclusiva -, ele só existe enquanto cinema, isto é, enquanto fruto de uma operação de montagem, de recorte, de seleção, de subtração e de construção narrativa. A montagem, ao respeitar a temporalidade das experiências dos passageiros (sem fetichizar a duração dos planos ou promover sínteses sociais na fragmentação), ao se empenhar em construir personagens dotados de progressão dramática (construção essa bastante clássica por sinal), enfim, ao instaurar um universo próprio e nos permitir por lá nos instalarmos, retoma, paradoxalmente, uma das qualidades mais clássicas do cinema - como se só pudéssemos perceber a instabilidade dessas imagens por meio da estabilidade (por mais sutil que seja) 
proporcionada pela organização do filme. A montagem, portanto, ao constituir uma obra, enfrenta a grande urgência das imagens de Pacific, essas imagens que parecem deixar pouco espaço para além delas mesmas: "permitir que um fora se insinue" (Brasil, 2010).

Vale ressaltar que o pensamento acerca da "experiência do fora" atravessa a obra, literária e filosófica, de três grandes pensadores franceses, Maurice Blanchot, Michel Foucault e Gilles Deleuze (Levy, 2003), com implicações distintas. Mas é na teoria política que a especulação sobre o "fim do fora" (a partir da herança deleuziana) foi promovida à questão central de nossa "sociedade mundial de controle". Segundo Michael Hardt (2000:358), em artigo de 1996 ainda hoje dotado de interesse, a despeito de sua perspectiva totalizante e como que emitida à distância de um satélite, a dialética moderna do fora e do dentro, concebida em termos hegelianos, fora substituída por um jogo de graus, intensidades e hibridismos. Isto é, poderíamos acrescentar, por um movimento de indeterminação dos pólos e das "fronteiras" (para usar o jargão) que constituíam os alicerces da Modernidade. Nesse sentido, o fora entra em declínio como aquilo que definia a relação entre o público e o privado na teoria política liberal e a defesa de "políticas de inclusão", sobretudo pelo consumo, torna-se hoje a palavra de ordem de um movimento de redução da política a estratégias de gestão. Portanto, se o espaço público (que modernamente é o lugar próprio da política) tem sido cada vez mais privatizado, o fim do fora, segundo Hardt (2000:361), significaria "o fim da política liberal" e a consolidação do "mercado mundial", que, em sua forma ideal, sempre se opôs a qualquer divisão entre dentro e fora.

Se o inclusivo regime performativo das imagens, as capilarizadas estratégias interativas e colaborativas do poder e a permanente apropriação da "mais-valia" do trabalho dos amadores pela mídia e pelas forças do mercado colocam o fora em questão, é importante ter em vista que essas mesmas imagens também fazem entrar em curtocircuito a oposição entre aqueles que olham e aqueles que agem, entre aqueles que, separados, só podem olhar, e aqueles a quem é dado o direito de agir e de participar. Nesse sentido, seria interessante nos perguntarmos - adaptando às imagens amadoras o que Jacques Rancière (2010) se indaga em relação ao romance realista (precisamente em obras de Flaubert e Dostoievski) -, se os efeitos de realidade (com seus excessos descritivos) e a dimensão biopolítica (sustentada pela capitalização da vida ordinária) próprios a essa produção amadora não poderiam ser considerados parte de uma outra "partilha do sensível" (Rancière, 2005), de uma outra distribuição das "ocupações" que 
não pressuponha uma oposição entre olhar e agir, entre passividade e atividade. Enfim, se os efeitos de realidade e a dimensão biopolítica próprios a essa produção amadora não poderiam ser considerados parte de outra sensibilidade, no dizer de Rancière, menos elitista e mais democrática. Sem dúvida, as imagens vicárias e trepidantes de Pacific, produzidas por uma classe social muito bem demarcada, nos interpelam com essas questões, solicitando a nós, espectadores, uma avaliação que não deixa de levar em conta de que lugar social, a partir de quais condicionamentos e preconceitos, as julgamos.

\section{Deslocamento e montagem}

É notável de que modo a montagem de Pacific, ao se apropriar de imagens amadoras $^{110}$ e alheias, deslocando-as de seus usos originais, trabalha com uma espécie particular de material de arquivo, mas um arquivo do presente e de presenças, vivo e movediço. Agenciando, portanto, uma multiplicidade de pontos de vista sempre instáveis e erráticos, a montagem - ainda que construa uma narrativa provida de personagens e cronologia - opera um deslocamento, um anacronismo, optando por uma enunciação recolhida e por uma sutil desestabilização dos sentidos. Em Pacific, após as palavras iniciais em que se explicita o dispositivo, não há um único comentário do diretor, nem por meio de cartelas, narração ou pela presença de óbvios contrapontos críticos no interior do filme. Uma vez dentro do navio lá permaneceremos. Nessa espécie de "retirada estética" do cineasta, a crítica possível ou o "comentário recolhido" se fazem presentes, portanto, pelo gesto da montagem.

Normalmente, a tradição das imagens de arquivo baseia-se no retomar imagens já constituídas para lhes conferir um novo sentido (Lins, 2010), mas aqui se retoma para não conferir sentido algum (ao menos sentidos explícitos) para além do que é visível e audível, para alem de um sentido estritamente narrativo. Pedroso, que é o roteirista, o diretor e o montador, ainda que organize uma estrutura narrativa a partir da desorganização das determinações do navio, ainda que organize a entropia das imagens

\footnotetext{
${ }^{110}$ Faz-se o momento de lembrar que as "imagens amadoras", para um autor como Roger Odin, são definidas segundo seus espaços institucionais e sociais de prática cinematográfica, como o espaço da família, o do clube de cineastas amadores e o espaço dos "outros cinemas" (como o cinema marginal ou experimental), ainda que esses espaços possam ser híbridos - hibridismo e indeterminação que nos interessa no âmbito desta pesquisa, já que nosso objetivo não é classificá-las, mas perceber seus polimorfos modos de circulação e inscrição. Ver ODIN, Roger. Les film de famille. Usage privé, usage public. Paris: Meridiens Klinckieck, 1995.
} 
a partir da dissipação da hipertrofia daquelas subjetividades, em suma, ainda que dê forma ao informe, ele não as ressignifica. Não produz interpretações ou sínteses de representações sociais. Deslocar e organizar, portanto, não pertencem nesse caso à ordem da hermenêutica, mas antes à ordem do gesto, um gesto que, como bem sabe a tradição sofística, não fala sobre "o que é”, mas faz ser, em suas próprias operações, aquilo que diz.

Essa dimensão performativa (e não representacional) do próprio gesto do cineasta como mediação incontornável solicita de nós espectadores que não julguemos dicotomicamente e impiedosamente aquele mundo, aquelas formas de vida, mas que busquemos, como espectadores ativos, um contraponto crítico em nosso próprio mundo histórico e social, pois o filme mesmo não nos oferece esse contraponto - tal como ocorre, por exemplo, no documentário espanhol Holidays, de Victor Moreno (2010), que faz uso de vicários arquivos audiovisuais de turistas na ilha de Lanzarote, na Espanha, ao mesmo tempo em que articula esse material à vida daqueles que ali moram e que não estão de passagem. Em Holidays, os que moram no interior da ilha, e passam seus dias a trabalhar, constituem o próprio "fora" do filme.

Nessa suspensão de sentido, nessa suposta ausência de fora (a vida dos passageiros fora do navio, fora das férias, fora da festa do consumo), Pacific nega o consenso de uma posição fácil, estável. Recusa o que poderia ser percebido como grotesco e simplesmente caricato, o que ele poderia fazer na montagem e não faz. E oferece a nós espectadores o assombro de habitarmos uma posição indeterminada, ambígua, entre o distanciamento crítico e o engajamento afetivo, a recusa e a adesão, o fora e o dentro, demandando-nos não um julgamento, mas uma avaliação. Talvez, seria possível supor, ao serem construídos como pura exterioridade, tanto o filme propriamente dito quanto as imagens das quais ele se apropria já constituiriam um fora: não o não-lugar das utopias, mas os outros lugares, separados e ligados, isolados e visíveis, das heterotopias (Foucault, 1967 apud Brasil, 2010). Se, como dizia Foucault, "a visibilidade é uma armadilha", a montagem, ao duplicar ou desdobrar o excesso de visibilidade daquelas imagens, não visa desdobrar as armadilhas, jogar cinicamente com o espectador, mas tensionar uma visibilidade à outra, desfazer sua lisura, como numa dobradiça $^{111}$.

\footnotetext{
${ }^{111} \mathrm{O}$ gesto de tensionar uma visibilidade à outra, desdobrar imagens, criar dobradiças, é explícito em Rua de mão dupla, de Cao Guimarães (2004), e perceptível em Avenida Brasília Formosa, de Gabriel Mascaro (2010), naqueles momentos em que o filme incorpora as imagens produzidas por um de seus
} 
Em Pacific, a montagem, ao buscar um posicionamento crítico que não abra mão da experiência e da presença dos personagens do filme nem da ambivalência de sua construção, ao buscar um deslocamento e não um distanciamento, exige de todos nós, produtores, portadores e espectadores das imagens, outro tipo de engajamento reflexivo, outro tipo de posição. No gesto do montador estaria a liberdade possível, no dizer do personagem Alexandre, do filme La maman et la putain, de Jean Eustache (1973): a liberdade de falar com as palavras dos outros, a liberdade de fazer filmes com imagens outras, a liberdade de ser, em relação ao outro, também um outro. Em Pacific - como também se percebe de formas distintas em Rua de mão dupla, Avenida Brasília Formosa e Viajo porque preciso, volto porque te amo - trata-se de achar e repor a distância justa, precisa, adequada, para que a inadequação dos sujeitos ao mundo (ainda que em Pacific essa inadequação apareça sob a discreta forma do cansaço), para que a defasagem entre a experiência e a imagem (que em Pacific nunca parece estar à altura da estridência das expectativas e dos desejos), possam enfim reconfigurar e perturbar certa ordem consensual do visível.

Assim, a montagem de Pacific não está de todo acabada e o "espectadormontador" (Lins, 2011) também é impelido a trabalhar: a tomar uma posição, a ser uma testemunha privilegiada não exatamente de um estado de mundo, mas das imagens produzidas e produtoras desse mundo. Lembremos da última seqüência, em que a mediação pela imagem e pelo dinheiro volta a comparecer em toda a sua força: na festa de Réveillon, já no final da viagem, o navio inteiro canta o bordão - "Feliz ano novo / Adeus ano velho / Que tudo se realize no ano que vai nascer / Muito dinheiro no bolso / Saúde pra dar e vender..." - e, em meio à música e aos celebratórios fogos de artifício, o gesto do montador, em corte seco e cirúrgico, interrompe a festa, interrompe o filme. A promessa da bonança vindoura é abortada. A classe média abandonará o paraíso do consumo sem limites e se preparará para as futuras prestações do cartão de crédito. Mas eles não voltarão ao trabalho, pois nunca deixaram de trabalhar.

personagens (o garçom Fábio que nas horas vagas é cinegrafista amador), como o vídeo da festa infantil do menino Cauan, o vídeo encomendado pela manicure Débora para que ela possa pleitear uma vaga no Big Brother Brasil, dentre outros materiais fetichizados. 
Se a performance constitui o grande trabalho contemporâneo, cabe lembrar que outros filmes investem na performática "rentabilidade cênica" de modo menos difuso, menos sutil, mais alarmante. Tal é o caso das obras analisadas na dissertação "O 'modelo egológico' no documentário brasileiro: a individualização pela rentabilidade cênica", de Cléber Eduardo. De acordo com a perspectiva do autor, o "modelo sociológico" (Bernardet, 2003), pautado pela produção de esquemas de significação comprometidos com o diagnóstico geral e com a síntese social por meio de personagens "representativos" (e nada "singularidades"), fora substituído pelo "modelo egológico", não necessariamente hegemônico, mas bastante recorrente. Nesse deslocamento está em curso a substituição do povo pelo personagem, do tipo pelo particular, dos títulos que anunciavam uma questão geral pelos nomes próprios. São esses nomes próprios, personagens-protagonistas, singulares e carismáticos, talentosos e exóticos, que se põem a trabalhar performática e "profissionalmente", em troca do reconhecimento de suas capacidades e talentos pela conquista da visibilidade. Nesse caso, não se trata do trabalho ordinário (mesmo na chave do regime performativo) dos amadores, mas da vida extraordinária de personagens que trabalham e rendem como "profissionais" - em um contexto em que certa "ditadura" da rentabilidade é exercida em nome de uma "democracia" cênica.

A partir dessa problemática, poderíamos nos perguntar, em relação ao cinema de Eduardo Coutinho, por exemplo, como ficam seus personagens "extraordinários" (termo bastante empregado pelo próprio Coutinho). Certamente é uma boa questão, mas que não pode ser remetida à "obra" do "autor", pois que nem o autor preexiste à obra, nem a obra nos interessa como um conjunto supostamente coerente e fechado. Cabe então interrogar e avaliar filme a filme, já que se Coutinho, pelo menos desde Santo forte (1997), costuma lançar mão de um dispositivo recorrente, o recurso à entrevista - em suas variações, radicalizações (caso de Jogo de cena, 2007) ou desvios radicais (caso de Moscou, 2009, e Um dia na vida ${ }^{112}$, 2010) -, nem mesmo essa recorrência garantiria

${ }^{112}$ Em Um dia na vida (2010), Coutinho se apropria, como que seqüestrando, pilhando, imagens da televisão. Da manhã do dia 1 à madrugada do dia 2 de outubro de 2010, ele e sua equipe gravaram 19 horas de programação de televisão aberta brasileira, entre programas matutinos, religiosos, femininos, de auditório, telecursos, telejornais, novelas, reality shows de transformação cirúrgica, canais de venda e propaganda política. Desse material, Coutinho e sua montadora organizaram um "experimento" com pouco mais de uma hora e meia, cujo critério prévio era respeitar a cronologia da programação, tentar manter, tanto quanto possível, a duração dos blocos dos programas, e não produzir nenhum tipo de interferência ou comentário (seja por cartelas ou narração) para além do gesto da montagem, visando, ao final, à exibição em salas de cinema, em sessões especiais e "clandestinas" (isto é, sem divulgação na imprensa), já que o diretor não dispõe dos direitos legais das imagens televisivas. Como uma espécie de ready made, de gesto dadaísta, a absoluta "retirada estética" do realizador (nem mesmo o nome de 
uma avaliação peremptória. No caso que mais nos interessa, o filme Jogo de cena, percebemos outro movimento, pois ali não se trata de uma excessiva auto-consciência de personagens "profissionais", mas da consciência de que a cena, seja a cena do teatro (onde o filme se passa), a cena social (onde a vida se desenrola) ou a cena amorosa (onde os afetos nascem e falecem), não é simplesmente um espaço de visibilidade, de luminosidade, de rentabilidade social. Antes, em Jogo de cena, a cena é também um espaço de isolamento e solidão (no palco do teatro e no quadro do cinema), de distância e separação (do personagem para consigo e do personagem para com o outro, o diretorentrevistador), de defasagem e subtração (já que um relato nunca está à altura de uma vida, assim como uma vida nunca está à altura de seu relato). Em Jogo de cena, a cena é, portanto, esse opaco lugar em que as personagens - sejam elas atrizes amadoras ou profissionais - podem comparecer ao próprio desencontro.

\section{Filmografia trabalhada}

Avenida Brasília Formosa, de Gabriel Mascaro (PE, 84', 2010)

Rua de mão dupla, de Cao Guimarães (MG, 75', 2004)

Pacific, de Marcelo Pedroso (PE, 72', 2009)

Viajo porque preciso, volto porque te amo, de Marcelo Gomes e Karim Ainouz (CE/PE/SP, 75', 2009)

\section{Filmografia comentada}

As aventuras de Paulo Bruscky, de Gabriel Mascaro (PE, 19’, 2010)

Um dia na vida, de Eduardo Coutinho (RJ, 95’, 2010)

A família Bartos, de Péter Forgács (Hungria, 61', 1988)

Coutinho aparece na "obra") e o violento deslocamento dessas imagens (do regime de desatenção da televisão para o regime de atenção coletiva da sala escura) produzem efeitos perturbadores, como se o espectador, concentrado e absorto diante da terrível realidade dos artifícios e dispositivos de sujeição da vida engendrados pela televisão, fosse tomado pelo assombro de uma experiência traumática: para a qual a realidade dessas imagens e experiências de sujeição só pudesse ser percebida (entre o riso nervoso, o escárnio cínico ou o silencio estupefato) como mero artifício. 
Fragmentos de uma revolução, de Anonymous (França, 55', 2010)

Holidays, de Víctor Moreno (Espanha, 85', 2010)

Um homem com uma câmera, de Dziga Vertov (União Soviética, 68', 1929)

Jardim Nova Bahia, de Aloysio Raulino (SP, 15', 1971)

Jogo de cena, de Eduardo Coutinho (RJ, 107', 2007)

Videogramas de uma revolução, de Harun Farocki e Andrei Ujica, (Romênia/Alemanha, 107', 1992);

\section{Filmografia mencionada}

33, de Kiko Goifman (MG, 75', 2003)

O almoço do bebê, de Louis Lumière (FR, 44', 1895)

Babás, de Consuelo Lins (RJ, 20', 2010)

A Bruxa de Blair, de Daniel Myrick e Eduardo Sánchez (EUA, 81', 1999),

Cloverfield, de Matt Reeves (EUA, 85', 2008)

Diário de uma busca, de Flávia Castro (França/Brasil, 104', 2011)

Edifício Master, de Eduardo Coutinho (RJ, 110’, 2002)

O filme de Angelo, de Péter Forgács (Hungria, 60’, 1999)

Janela indiscreta, de Alfred Hitchcock (EUA, 112', 1954)

La maman et la putain, de Jean Eustache (França, 217', 1973)

A opinião pública, de Arnaldo Jabor (RJ, 71', 1965)

Um passaporte húngaro, de Sandra Kogut (França/Brasil, 71', 2003)

REC, de Jaume Balagueró e Paco Plaza (Espanha, 78’, 2007)

Retrato de classe, de Gregório Bacic (SP, 42’, 1977)

Romance de formação, de Julia De Simone (RJ, 74', 2011)

Santiago, de João Moreira Salles (RJ, 79’, 2007)

Super 8, de J.J Abrams (EUA, 112', 2011)

Queda Livre, de Péter Forgács (Hungria, 75', 1996) 
O turbilhão, de Péter Forgács (Hungria, 60’, 1997)

O último a sair fecha a porta, de Carolina Fernandes e Lessandro Sócrates (SP, 52', 2009)

\section{Referências bibliográficas}

AGAMBEN, Giorgio. “O autor como gesto”. In: Profanações. São Paulo: Boitempo, 2007.

ANDRADE, Fabio. "Pacific: um filme para chamar de seu". Revista Cinética, jan. 2010. Disponível em: http://www.revistacinetica.com.br/pacific.htm

ARENDT, Hannah. A condição humana. Rio de Janeiro: Forense Universitária, 2005.

AUMONT, Jacques. "Lumière, 'o último pintor impressionista". In: O olho interminável (cinema e pintura). São Paulo: Cosac Naify, 2004.

BARTHES, Roland. "O efeito de real”. In: O rumor da língua. São Paulo: Martins Fontes, 2004. . “A morte do autor”. In: O rumor da língua. São Paulo: Martins Fontes, 2004.

BERNARDET, Jean-Claude. "Pacific". Blog do Jean-Claude Bernardet, 2011: Disponível em: http://jcbernardet.blog.uol.com.br/

. Cineastas e imagens do povo. Companhia das Letras, 2003.

."Documentários de busca: 33 e Passaporte húngaro". In: MOURÃO, Maria

Dora; LABAKI, Amir (orgs.) O cinema do real. São Paulo: Cosac Naify, 2005.

BEZERRA JR., Benilton. "O ocaso da interioridade e suas repercussões sobre a clínica". In: PLASTINO, Carlos Alberto (org.). Transgressões. Rio de Janeiro: Contra Capa, 2002.

BOLTANSKI, Luc; CHIAPELlO, Ève. O novo espírito do capitalismo. São Paulo: Martins Fontes, 2009.

BOURDIEU, Pierre. "A ilusão biográfica”. In: FERREIRA, M.M. \& AMADO, J. (coord.) In: Usos \& abusos da história oral. Rio de Janeiro: Editora da Fundação Getulio Vargas, 1996.

BRASIL, André. "Formas de vida na imagem: da indeterminação à inconstância", Trabalho apresentado ao GT Estéticas da Comunicação, XIX Encontro Anual da Compós, Puc-Rio, Rio de Janeiro, 2010.

.A performance: entre o vivido e o imaginado". Trabalho apresentado ao GT Comunicação e Experiência Estética, XX Encontro Anual da Compós, Universidade Federal do Rio Grande do Sul, Porto Alegre, de 14 a 17 de junho de 2011.

2010.

"Pacific: o navio, a dobra do filme". In: Devires, v.7, n.2, Belo Horizonte, UFMG

."Ensaio de uma revolução". Revista Cinética, set. de 2008. Disponível em: http://www.revistacinetica.com.br/videogramas.htm

BRASIL, André; MIGLIORIN, Cezar. "A gestão da autoria: anotações sobre ética, política e estética das imagens amadoras". In: Ciberlegenda, Revista do Programa de Pós-Graduação em Comunicação da UFF, Dossiê Realidade e Ficção, N 22, junho de 2010. 
.Biopolítica do amador: generalização de uma prática, limites de um conceito". In: Revista Galáxia, São Paulo, n. 20, p. 84-94, dez. 2010.

BRUNO, Fernanda."Quem está olhando? Variações do público e do privado em weblogs, fotologs e reality shows". In: Contemporânea - revista de comunicação e cultura, vol.03, n.02, dezembro de 2005, PósCOM UFBA.

"Máquinas de ver, modos de ser: visibilidade e subjetividade nas novas tecnologias de informação e comunicação". Revista FAMECOS, Porto Alegre, no. 24, jul. 2004.

COMOLLI, Jean-Louis "Cinema contra-espetáculo". In: Catálogo "forum.doc.bh.2001", 5. Festival do Filme Documentário e Etnográfico - Fórum de Antropologia, Cinema e Vídeo, Belo Horizonte, novembro de 2001.

"Os homens ordinários. A ficção documentária". In: O comum e a experiência da linguagem. GUIMARÃES, C.; OTTE, G.; SEDLMAYER, S. (orgs.). Belo Horizonte: UFMG, 2007.

"Retrospectiva do espectador". In: Ver e poder: a inocência perdida - cinema, televisão, ficção, documentário. Belo Horizonte: UFMG, 2008.

."Não pensar o outro, mas pensar que o outro me pensa". In: Devires - Cinema e Humanidades. Belo Horizonte: UFMG/FAFICH, v. 2, n. 1, jan-dez. 2004.

DEBORD, Guy. A Sociedade do Espetáculo. Rio de Janeiro: Contraponto, 2000.

DIDI-HUBERMAN, George. Images malgré tout. Paris: Les Éditions de Minuit, 2003. . Cuando las imágenes toman posición. Madrid: A. Machado Libros, 2008.

EDUARDO, Cléber. "O 'modelo egológico' no documentário brasileiro: a individualização pela rentabilidade cênica em Estamira e A pessoa é para o que nasce". Dissertação de mestrado apresentada ao Programa de Pós-Graduação em Ciências da Comunicação, ECA / USP, 2011.

EHRENBERG, Alain. $O$ culto da performance - da aventura empreendedora à depressão nervosa. São Paulo: Idéias e Letras, 2010.

FELDMAN, Ilana. "Do declínio da intimidade aos novos regimes de visibilidade". Pacific textos para debate. Recife: Funcutura / Fundarpe /Símio filmes, 2011.

. "A vida em cena: vida-produto, vida-lazer, vida-trabalho, vida-performance". In: Ciberlegenda - revista do Programa de Pós-Graduação em Comunicação da Universidade Federal Fluminense, Edição 22, $1^{\circ}$ sem. 2010. Disponível em: http://www.proppi.uff.br/ciberlegenda/vida-em-cena

."O apelo realista". In: Revista FAMECOS, "Dossiê Menções de Destaque - Compós

2008", Porto Alegre, n.36, ago. 2008. Disponível em: http://revcom2.portcom.intercom.org.br/index.php/famecos/article/viewFile/5472/4970

.Reality show: um dispositivo biopolítico". In: Estéticas da biopolítica: audiovisual, política e novas tecnologias. Revista Cinética / Programa Cultura e Pensamento (MinC), 2008. Disponível em: http://www.revistacinetica.com.br/cep/ilana feldman.htm

FOSTER, Hal. The Return of the Real. The avant-garde at the end of the century. Cambridge and London: MIT Press, 1996.

FOSTER, Lila Silva. "Filmes domésticos: uma abordagem a partir do acervo da Cinemateca Brasileira". Dissertação de mestrado apresentada ao Programa de Pós-Graduação em Imagem e Som da Universidade Federal de São Carlos. São Carlos: UFSCar, 2010.

FOUCAULT, Michel. História da sexualidade, vol.1, A vontade de saber. Rio de janeiro: Graal, 1997. 
"Nascimento da biopolítica". In: Resumo dos cursos do Collège de France (19701982). Rio de Janeiro: Jorge Zahar, 1997.

. "Aula de 17 de março de 1976". In: Em defesa da sociedade. São Paulo: Martins Fontes, 2005.

Graal, 2000.

"O nascimento da medicina social". In: Microfísica do poder. Rio de janeiro:

."O que é um autor?". In: Ditos e Escritos, vol. III. Rio de Janeiro: Forense, 2003.

"De outros espaços". Conferência proferida no Cercle d'Étude Architecturale, em

1967. Domínio público: http://www.ufrgs.br/corpoarteclinica/obra/outros.prn.pdf

GORZ, André. O imaterial - conhecimento, valor e capital. São Paulo: Annablume, 2005.

GUIMARÃES, César. "Um dia na vida do outro espectador". In: Revista Devires, Belo Horizonte, v. 7, n. 2, p. 132-138, jul/dez 2011.

."Documentário, testemunha do presente". In FURTADO, Beatriz (Org.) Imagem contemporânea - cinema, TV, documentário... vol. I. São Paulo: Hedra, 2009.

GUMBRECHT, Hans Ulrich. Produção de presença - o que o sentido não consegue transmitir. Rio de Janeiro: Contraponto / Ed. PUC-Rio, 2010.

HARDT, Michael. "A sociedade mundial de controle”. In: ALLIEZ, Éric (org.) Gilles Deleuze: uma vida filosófica. São Paulo: Ed. 34, 2000.

ILLOUZ, Eva. O amor nos tempos do capitalismo. Rio de Janeiro: Jorge Zahar, 2011.

JOURNOT, Marie-Thérèse. Films amateurs dans le cinéma de fiction. Paris: Armand Colin, 2011.

KLINGER, Diana. Escritas de si, escritas do outro - o retorno do autor e a virada etnográfica. Rio de Janeiro: 7Letras, 2007.

LAÉCIO, Ricardo. "O documentário e o enigma da alteridade". Pacific - textos para debate. Recife: Funcutura / Fundarpe /Símio filmes, 2011.

LEVY, Tatiana Salém. A experiência do fora - Blanchot, Foucault e Deleuze. Rio de Janeiro: Relume Dumará, 2003.

LINS, Consuelo. "A arte desmontar e remontar imagens - apropriação de arquivos no documentário brasileiro contemporâneo". In: HALLAK, Raquel (Org.) Cinema sem fronteiras 15 anos da Mostra de Cinema Brasileiro de Tiradentes (Reflexões sobre o cinema brasileiro 1998-2012). Belo Horizonte: Universo Produção, 2012.

."Do espectador crítico ao espectador montador: Um dia na vida, de Eduardo Coutinho". In: Devires, Belo Horizonte, v. 7, n. 2, p. 132-138, jul/dez 2011.

."Rua de Mão Dupla: documentário e arte contemporânea". In: MACIEL, Katia (Org.) Trasncinemas. Rio de Janeiro: Contracapa, 2009, p. 327-340

;CURSINO, Adriana. "O tempo do olhar: arquivos em documentários de observação e autobiográficos". In: Conexão - Comunicação e Cultura, UCS, Caxias do Sul, v.9, n.17, jan/jun. 2010.

;BLANK."Ruínas da intimidade: os 'objetos encontrados' de Péter Forgács". In: REBELLO, Patrícia; SAMPAIO, Rafael (Orgs.). Péter Forgács: arquitetura da memória. São Paulo / Rio de Janeiro / Brasília: Centro Cultural Banco do Brasil, 2012.

MESQUITA, Cláudia. "Retratos em diálogo - notas sobre o documentário brasileiro recente". In: Novos estudos CEBRAP, n.86, março 2010. 
MIGLIORIN, Cezar. "A política no documentário". In: FURTADO, Beatriz (Org.) Imagem contemporânea - cinema, TV, documentário... vol. I. São Paulo: Hedra, 2009.

NICHOLS, Bill. Introdução ao documentário. Campinas, SP: Papirus, 2005.

ODIN, Roger. Les film de famille. Usage privé, usage public. Paris: Meridiens Klinckieck, 1995.

RANCIÈRE, Jacques. A partilha do sensível. Estética e política. São Paulo: Ed. 34, 2005. Le spectateur émancipé. Paris: La Fabrique, 2008. ."O efeito de realidade e a política da ficção". In: Novos Estudos, n. 86, março 2010.

SARLO, Beatriz. Tempo passado - cultura da memória e guinada subjetiva. São Paulo: Cia das Letras; Belo Horizonte: Ed. UFMG, 2007.

SIBILIA, Paula. O show do eu - a intimidade como espetáculo. Rio de Janeiro: Nova Fronteira, 2008.

SENNETT, Richard. O declínio do homem público - as tiranias da intimidade. São Paulo: Cia das Letras, 2002.

VELLOSO, Silvia Pimenta. "O perspectivismo em Nietzsche". In: DANOVSKI, Débora; PEREIRA, Luiz Carlos. In: $O$ que nos faz pensar. Cadernos do Departamento de Filosofia da PUC-Rio, set. 2004.

XAVIER, Ismail. O olhar e a cena - Melodrama, Hollywood, Cinema Novo, Nelson Rodrigues. São Paulo: Cosac\&Naify, 2003.

"Ressentimento e realismo ameno", entrevista concedida a Mario Sérgio Conti. In: MENDES, Adilson (Org.) Ismail Xavier. Rio de Janeiro, Azougue, 2009. ."El exemplar y lo contingente en el teatro de las evidencias", revista Pensamiento de los Confines v.25, Buenos Aires, 2009. "O efeito-janela e a identificação". In: $O$ discurso cinematográfico - a opacidade e a transparência. São Paulo: Paz e Terra, 2005 ."Indagações em torno de Eduardo Coutinho e seu diálogo com a tradição moderna". In: MIGLIORIN, Cezar (Org.) Ensaios no real. Rio de Janeiro: Azougue, 2010.

WAJCMAN, Gérad. Fenêtre - Chroniques du regard et de l'intime. Paris: Verdier, 2004.

ZIMMERMANN, Patricia. Reel families: a social history of amateur film. Bloomington Indianapolis: Indiana University Press, 1995.

ZIZEK, Slavoj. Bem-vindo ao deserto do Real. São Paulo: Boitempo, 2003. ."Le Sujet Interpassif". In: La subjectivité à venir. Paris: Champs Flammarion, 2006.

ZUMTHOR, Paul. "Em torno da ideia de performance". In: Performance, recepção, leitura. São Paulo: Cosac Naify, 2007. 


\section{REFERÊNCIAS BIBLIOGRÁFICAS GERAIS}


ADORNO, Theodor. "O ensaio como forma". In: Notas de Literatura I. São Paulo: Editora 34 e Duas Cidades, 2003.

ANDRÉ, Serge. Que veut une femme? Paris: Éditions du Seuil, 1995.

ASSIS, Machado de. Dom Casmurro. São Paulo: Editora Globo, 1997.

BALTAR, Mariana. "Pacto de Intimidade - ou possibilidades de diálogo entre o documentário de Eduardo Coutinho e a imaginação melodramática". Artigo apresentado no XIV Encontro da Compós - GT Fotografia, Cinema e Vídeo, Niterói, RJ, 2005.

BARTHES, Roland. "O efeito de real". In: O rumor da língua. São Paulo: Martins Fontes, 2004. A câmera clara. Rio de Janeiro: Nova Fronteira, 1984.

BENJAMIN, Walter. "A imagem de Proust". In: Magia e técnica, arte e política. São Paulo: Brasiliense, 1994.

BERNARDET, Jean-Claude. "Jogo de cena", 14/01/2008. Disponível no "Blog do JeanClaude", em: http://jcbernardet.blog.uol.com.br/ . Cineastas e imagens do povo. São Paulo: Cia das Letras, 2003.

BRAGANÇA, Felipe. "Mestres dos mestres". Revista eletrônica Contracampo, 2004. Disponível em: http://www.contracampo.com.br/58/jeanrouch.htm

BRASIL, André. "Ensaios de uma imagem só". In: Devires, Belo Horizonte, v.3, n.1, jan-dez., 2006.

"A tela em branco: da origem do ensaio ao ensaio como origem". Trabalho apresentação ao GT Fotografia, Cinema e Vídeo, XVIII Encontro Anual da Compós, Puc-BH, Belo Horizonte, MG, 2009.

BRUNO, Fernanda. "Jogo de cena", 2007. Disponível no blog "Dispositivos de visibilidade e subjetividade contemporânea", em: http://dispositivodevisibilidade.blogspot.com/2007/11/jogode-cena.html

CAETANO, Daniel. "Um fantasma se movimenta - o vazio em Moscou como gesto, idéia e presença". Cinética, $2009 . \quad$ Det. http://www.revistacinetica.com.br/moscoucae.htm

CASSIN, Bárbara. Voir Helène em toute femme. Paris: Institut Sanofi-Synthélabo, 2000.

COMOLLI, Jean-Louis. Ver e poder: a inocência perdida - cinema, televisão, ficção, documentário. Belo Horizonte: UFMG, 2008.

"Os homens ordinários. A ficção documentária". In: O comum e a experiência da linguagem. GUIMARÃES, C.; OTTE, G.; SEDLMAYER, S. (orgs.). Belo Horizonte: UFMG, 2007.

"Não pensar o outro, mas pensar que o outro me pensa - entrevista com JeanLouis Comolli”. In: Revista Devires, Belo Horizonte, v.02, n.01, jan-dez. 2004.

DAHLET, Patrick. "Dialogização enunciativa e paisagens do sujeito". In: BRAIT, Beth (org.). Bakhtin - dialogismo e construção do sentido. Campinas: Ed. UNICAMP, 2008.

DA-RIN, Silvio. "Verdade e imaginação". In: Espelho partilho - tradição e transformação do documentário. Rio de Janeiro: Azougue, 2004. 
DESCARTES, René. Descartes, Vida e Obra. Coleção Os Pensadores. São Paulo: Ed. Nova Cultural, 2004. Trad. Bento Prado Jr.

DELEUZE, Gilles. "Postulados da lingüística”. In: Mil Platôs, Vol.II. São Paulo: Ed.34, 1995. .As potências do falso". In: A Imagem-Tempo. SP: Editora Brasiliense, 2005. .GUATTARI, Felix."Devir-intenso, devir-animal, devir imperceptível”. In: Mil Platôs, Vol.IV. São Paulo: Ed.34, 2004.

.PARNET, Claire. "Da superioridade da literatura anglo-americana". In: Diálogos.

São Paulo: Escuta, 1998.

DETIÈNNE, Marcel. Os mestres da verdade na Grécia arcaica. Rio de Janeiro: Jorge Zahar, 1993.

EDUARDO, Cléber. "O modelo egológico e a rentabilidade cênica em Estamira e A pessoa é para o que nasce", dissertação de mestrado apresentada ao Programa de Pós-Graduação em Ciências da Comunicação, ECA / USP, 2011.

"Subjetividade mediada: entre a classe social e a família universal". Revista Cinética, mar., 2007. Disponível em: http://www.revistacinetica.com.br/santiagocleber.htm

FELDMAN, Ilana. "Na contramão do confessional: o ensaísmo em Santiago, de João Moreira Salles, Jogo de cena, de Eduardo Coutinho, e Pan-cinema permanente, de Carlos Nader". In: MIGLIORIN, Cezar (org.) Ensaios no Real. Rio de Janeiro: Azougue, 2010.

."Santiago sob suspeita". Trópico. ago-set, 2007. Disponível em: http://pphp.uol.com.br/tropico/html/textos/2907,1.shl ."O apelo realista". In: Revista FAMECOS, Dossiê Menções de Destaque Compós 2008", Porto Alegre, n.36, 2008. Disponível em: http://revcom2.portcom.intercom.org.br/index.php/famecos/article/viewFile/5472/4970 "Moscou: do inacabamento ao filme que não acabou". Revista Cinética, abril de 2009. Disponível em: http://www.revistacinetica.com.br/moscouilana

FERRAZ, Maria Cristina Franco. "Teatro e máscara no pensamento de Nietzsche" e "O simulacro e suas implicações em Deleuze, Nietzsche e Kafka”. In: Nove variações sobre temas nietzschianos. Rio de Janeiro: Relume Dumará, 2002.

.Verdade-mulher, amor e amizade em Nietzsche". In: AZEVEDO, Vânia Dutra (Org.). Falando de Nietzsche. Ijuí: Unijuí, 2005, p. 115-129.

FOUCAULT, Michel. História da sexualidade, vol.1, A vontade de saber. Rio de Janeiro: Graal, 1997.

FRANÇA, Andréa. "O documentário entre a cena do tribunal e a cena do teatro". Trabalho apresentado ao XVIII Encontro Anual da COMPÓS, PUC-MG, Belo Horizonte/BH, 2009.

GUIMARÃES, César. “A singularidade como figura lógica e estética no documentário". In: Revista Alceu, vol.07, n.13, jul./dez. 2006, p.38 a 48.

LINS, Consuelo. O documentário de Eduardo Coutinho. Rio de Janeiro: Jorge Zahar, 2004.

LINS, Consuelo; MESQUITA, Cláudia. "Crer, não crer, crer apesar de tudo - a questão da crença nas imagens na recente produção documental brasileira". Trabalho apresentado ao XVII Encontro Anual da Compós - GT Fotografia, Cinema e Vídeo. UNIP, São Paulo, SP, 2008.

LISPECTOR, Clarice. A paixão segundo GH. Rio de Janeiro: Rocco, 1998. . Água viva. São Paulo: Editora Círculo do Livro, 1976. 
LOPES, Silvina Rodrigues. "Do ensaio como pensamento experimental". In: Literatura, defesa do atrito. Lisboa: Vendaval: 2003.

LORAUX, Nicole. Les mères en deuil. Paris: Seuil, 1990.

KEHL, Maria Rita. Deslocamentos de feminino. Rio de Janeiro: Imago, 2008.

MENDONÇA, Alexandre Ferreira. "Nietzsche e a Ficção da Verdade". Tese de Doutorado apresentada ao Programa de Pós-Graduação em Filosofia da UFRJ. Rio de Janeiro. Rio de Janeiro: 2004.

MÉNIL, Alain. "Entre utopie et héresie: quelques remarques à propôs de la notion d'essai". In: LIANDRAT-GUIGNES, Suzanne; GAGNEBIN, Murielle (orgs.) L'essai e le cinéma. Paris: Champ Vallon, 2004.

MESQUITA, Cláudia. "Retratos em diálogo - notas sobre o documentário brasileiro recente". In: Novos estudos CEBRAP, n.86, março 2010.

MIGLIORIM, Cezar. "Jogo de cena - de Eduardo Coutinho (2)". Disponível no blog "Polis + Arte", 2007. Disponível em: http://a8000.blogspot.com/2007/10/jogo-de-cena-de-eduardocoutinho-2.html

PRADO Jr., Plinio Walder. "Confessions (III) - Structure du Double". Texto de apresentação do curso de mesmo nome, no âmbito da Faculdade de Filosofia da Universidade Paris 8, ocorrido em 2008/2009.

ROSSET, Clément. O princípio da crueldade. Rio de Janeiro: Rocco, 1989.

SARLO, Beatriz. Tempo passado - cultura da memória e guinada subjetiva. São Paulo: Cia das Letras; Belo Horizonte: Ed. UFMG, 2007.

SENNETT, Richard. O declínio do homem público - as tiranias da intimidade. São Paulo: Cia das Letras, 2002.

SENRA, Stella. "Perguntar (não) ofende - anotações sobre a entrevista: de Gláuber Rocha ao documentário brasileiro recente". In: MIGLIORIN, Cezar. Ensaios no Real. Rio de Janeiro: Azougue, 2010 (no prelo).

SEVERINO, Antonio Marcos Vieira. "Pequenas notas sobre o ensaio". In: Revista História UNISINOS, vol. 08, n.10, julh./dez., p. 97-106, 2004.

SIBILIA, Paula. O show do eu - a intimidade como espetáculo. Rio de Janeiro: Nova Fronteira, 2008.

SIQUEIRA, Marília Rocha de. "O ensaio e as travessias no cinema documentário". Dissertação apresentada ao Programa de Pós-Graduação em Comunicação Social da Faculdade de Filosofia e Ciências Humanas da Universidade Federal de Minas Gerais, jun. de 2006.

STAROBINSKI. Jean. "Peut-on défini l'Essai?" In: BONNET, Jacques (org.). Jean Starobinski. Collection cahiers pour un temps. Paris: Centre Pompidou, 1985.

TODOROV, Tzvetan. "Os homens-narrativas" e "Introdução ao verossímil". In: Poética da Prosa. São Paulo: Martins Fontes, 2003. 
XAVIER, Ismail. O olhar e a cena - Melodrama, Hollywood, Cinema Novo, Nelson Rodrigues. São Paulo: Cosac\&Naify, 2003.

"Teoria e história no estudo de cinema no Brasi - entrevista a Adilson Mendes". In: Ismail Xavier. MENDES, Adilson (org.) Rio de Janeiro: Azougue, 2009.

"El exemplar y lo contingente en el teatro de las evidencias", revista Pensamiento de los Confines v.25, Buenos Aires, 2009.

"Indagações em torno de Eduardo Coutinho e seu diálogo com a tradição moderna". In: MIGLIORIN, Cezar (org.) Ensaios no real. Rio de Janeiro: Azougue, 2010. 


\section{REFERÊNCIAS BIBLIOGRÁFICAS GERAIS}


ADORNO, Theodor. "O ensaio como forma”. In: Notas de Literatura I. São Paulo: Editora 34 e Duas Cidades, 2003.

AGAMBEN, Giorgio. Homo Sacer - o poder soberano e a vida nua. Belo Horizonte: Ed. UFMG, 2002.

. Estado de exceção. São Paulo: Boitempo, 2004.

."Le visage". In: Moyens sans fins. Notes sur la politique. Paris: Payot \& Rivages,

2002.

.A linguagem e a morte. Belo Horizonte: E. UFMG, 2006.

. Profanações. São Paulo: Boitempo, 2007.

La communauté qui vient - theorie de la singularité quelconque. Paris: Seuil,

1990.

Qu'est-ce que le contemporain? Paris: Payot \& Rivages, 2008.

Qu'est-ce qu'un dispositif? Paris: Éditions Payot \& Rivages, 2007.

.O que resta de Auschwitz. São Paulo: Boitempo, 2008.

ANDRÉ, Serge. Que veut une femme? Paris: Éditions du Seuil, 1995.

ARENDT, Hannah. As Origens do Totalitarismo. São Paulo: Cia das Letras, 1989. . Compreensão e Política, Lisboa: Relógio D’água, 1993.

. A condição humana. Rio de Janeiro: Forense Universitária, 2005.

ARFUCH, Leonor. O espaço biográfico - dilemas da subjetividade contemporânea. Rio de Janeiro: EdUERJ, 2010.

ARLINDO, Machado. "O filme-ensaio". In: Intermídias, edição 5 e 6, 2006. Disponível em: www.intermidias.com/miolo/cinema home.htm

Paulus, 2007.

O sujeito na tela - modos de enunciação no cinema e no ciberespaço. São Paulo:

ASSIS, Machado de. Dom Casmurro. São Paulo: Editora Globo, 1997.

AUMONT, Jacques. Du visage au cinéma. Paris: Editions Cahiers du Cinéma, 1992.

.Lumière, 'o último pintor impressionista"”. In: $O$ olho interminável (cinema e pintura). São Paulo: Cosac Naify, 2004.

BALTAR, Mariana. "Realidade lacrimosa: diálogos entre o universo do documentário e a imaginação melodramática". Tese de doutorado / Universidade Federal Fluminense, Programa de Pós-Graduação em Comunicação, 2007.

.Pacto de Intimidade - ou possibilidades de diálogo entre o documentário de Eduardo

Coutinho e a imaginação melodramática". Artigo apresentado no XIV Encontro Anual da Compós - GT Fotografia, Cinema e Vídeo, Niterói, RJ, 2005.

BALÁZS, Béla. "O homem visível”. In: XAVIER, Ismail (org.) A experiência do cinema. Rio de Janeiro: Graal, 2003.

BARTHES, Roland. "O efeito de real". In: O rumor da língua. São Paulo: Martins Fontes, 2004. . "A morte do autor". In: O rumor da língua. São Paulo: Martins Fontes, 2004. A câmera clara. Rio de Janeiro: Nova Fronteira, 1984.

2004. "Diderot, Brecht e Eisenstein". In: O óvio e o obtuso. São Paulo: Edições 70, 
BAZIN, André. "Ontologia da imagem fotográfica" e "O mito do cinema total". In: Ensaios. São Paulo: Brasiliense, 1991.

BENJAMIN, Walter. “A imagem de Proust”. In: Magia e técnica, arte e política. São Paulo: Brasiliense, 1994.

BERNARDET, Jean-Claude. "Jogo de cena", 14/01/2008. Disponível no "Blog do JeanClaude", em: http://jcbernardet.blog.uol.com.br/ . Cineastas e Imagens do Povo. São Paulo: Cia. Das Letras, 2003. . Caminhos de Kiarostami. São Paulo: Cia das Letras, 2004. ."Documentários de busca: 33 e Passaporte húngaro". In: MOURÃO, Maria Dora; LABAKI, Amir (orgs.) O cinema do real. São Paulo: Cosac Naify, 2005.

BEZERRA JR., Benilton. "O ocaso da interioridade e suas repercussões sobre a clínica". In: PLASTINO, Carlos Alberto (org.). Transgressões. Rio de Janeiro: Contra Capa, 2002.

BIRCHAL, Telma de Souza. O eu nos ensaios de Montaigne. Belo Horizonte: UFMG, 2007. . "Montaigne e a Modernidade". In: Kriterion - Revista de Filosofia. Departamento de Filosofia da Faculdade de Filosofia e Ciências Humanas da UFMG, n. 86, ago. a dez. de 1992.

BLANCHOT, Maurice. L'espace littéraire. Paris: Gallimard, 1988. . Une voix venue d'ailleurs. Paris: Gallimard, 2002.

BOLTANSKI, Luc; CHIAPELLO, Ève. O novo espírito do capitalismo. São Paulo: Martins Fontes, 2009.

BRASIL, André. "A performance: entre o vivido e o imaginado". Trabalho apresentado ao GT Comunicação e Experiência Estética, XX Encontro Anual da Compós, Universidade Federal do Rio Grande do Sul, Porto Alegre, de 14 a 17 de junho de 2011. UFMG 2010.

"Pacific: o navio, a dobra do filme". In: revista Devires, v.7, n.2, Belo Horizonte, .Formas de vida na imagem: da indeterminação à inconstância". Trabalho apresentado ao GT Estéticas da Comunicação, XIX Encontro Anual da Compós, Puc-Rio, Rio de Janeiro, 2010.

"A tela em branco: da origem do ensaio ao ensaio como origem". In: Significação (ECA/USP), n.31, outono-inverno 2009.

"O ensaio, pensamento 'ao vivo"”. In: FURTADO, Beatriz (org.) Imagem contemporânea - cinema, TV, documentário... vol. I. São Paulo: Hedra, 2009.

.Ensaio de uma revolução". Revista Cinética, set. de 2008. Disponível em: http://www.revistacinetica.com.br/videogramas.htm

."Carapiru-Andrea, Spinoza. A variação dos afetos em Serras da desordem". In: Devires. UFMG, Belo Horizonte, v.5 n.2, 2008. 2006. "Ensaios de uma imagem só". In: Devires. UFMG, Belo Horizonte, v.3, n.1, jan-dez.,

BRASIL, André; MIGLIORIN, Cezar. "A gestão da autoria: anotações sobre ética, política e estética das imagens amadoras". In: Ciberlegenda, Revista do Programa de Pós-Graduação em Comunicação da UFF, Dossiê Realidade e Ficção, N 22 , junho de 2010.

."Biopolítica do amador: generalização de uma prática, limites de um conceito". Revista Galáxia, São Paulo, n. 20, p. 84-94, dez. 2010.

"Be stupid: a Diesel e o biopoder". In: Ciberlegenda - revista do Programa de PósGraduação em Comunicação da Universidade Federal Fluminense, Edição 22, $1^{\circ}$ sem. 2010. Disponível em: http://www.proppi.uff.br/ciberlegenda/be-stupid

."Saddam e Cicarelli: nossas imagens". Revista Cinética, 2006. Disponível em: http://www.revistacinetica.com.br/saddamcicarelli.htm 
BRAGANÇA, Felipe. "Mestres dos mestres". Revista eletrônica Contracampo, 2004. Disponível em: http://www.contracampo.com.br/58/jeanrouch.htm

BRUNO, Fernanda."Jogo de cena", 2007. Disponível no blog "Dispositivos de visibilidade e subjetividade contemporânea", em: http://dispositivodevisibilidade.blogspot.com/2007/11/jogode-cena.html

."Estética do flagrante: Controle e prazer nos dispositivos de vigilância contemporâneos". In: Estéticas da biopolítica: audiovisual, política e novas tecnologias. Revista Cinética / Programa Cultura e Pensamento (MinC), 2008. Disponível em: http://www.revistacinetica.com.br/cep/fernanda_bruno.htm

."Quem está olhando? Variações do público e do privado em weblogs, fotologs e reality shows". In: Contemporânea - revista de comunicação e cultura, vol.03, n.02, dezembro de 2005 - PÓSCOM - UFBA.

"Máquinas de ver, modos de ser: visibilidade e subjetividade nas novas tecnologias de informação e comunicação". Revista Famecos, Porto Alegre, no. 24, jul. 2004.

BOURDIEU, Pierre. "A ilusão biográfica”. In: FERREIRA, M.M. \& AMADO, J. (coord.) Usos \& abusos da história oral. Rio de Janeiro: Editora da Fundação Getulio Vargas, 1996.

BUCCI, Eugênio; KEHL, Maria Rita. Videologias. São Paulo: Boitempo, 2004.

CAETANO, Daniel (org.) Serras da Desordem. Rio de Janeiro: Azougue, 2008.

"Um fantasma se movimenta - o vazio em Moscou como gesto, idéia e presença".

Cinética, set. 2009. Disponível em: http://www.revistacinetica.com.br/moscoucae.htm

CASSIN, Bárbara. Voir Helène em toute femme. Paris: Institut Sanofi-Synthélabo, 2000.

CHALIER, Catherine. As matriarcas - Sara, Rebeca, Raquel e Lia. Petrópolis, Rio de Janeiro: Vozes, 1992.

Figures du féminin. Paris: Des femmes - Antoinette Fouque, 2006.

CLARCK, T. J. "Grotesco David com a bochecha inchada: um ensaio sobre o auto-retrato". In: SALZSTEIN, Sônia. (org.) Modernismos. São Paulo: CosacNaify, 2007.

COELHO, Maria Cecília M. N. "Considerações sobre ontología, retórica, imagen e verossimilhança em Platão". In: Discurso 39, USP, São Paulo, 2010 (no prelo).

COMOLLI, Jean-Louis. Ver e poder: a inocência perdida - cinema, televisão, ficção, documentário. Belo Horizonte: UFMG, 2008.

"Os homens ordinários. A ficção documentária". In: $O$ comum e a experiência da linguagem. GUIMARÃES, C.; OTTE, G.; SEDLMAYER, S. (orgs.). Belo Horizonte: UFMG, 2007.

"Sob o Risco do Real", "Cinema contra-espetáculo" e "Carta de Marselha sobre a auto-mise-en-scène". In: Catálogo "forum.doc.bh.2001", 5. Festival do Filme Documentário e Etnográfico - Fórum de Antropologia, Cinema e Vídeo, Belo Horizonte, novembro de 2001.

.Não pensar o outro, mas pensar que o outro me pensa". In: Devires - Cinema e Humanidades. Belo Horizonte: UFMG/FAFICH, v. 2, n. 1, jan-dez. 2004.

COSTA, Flávia Cesarino. O primeiro cinema - espetáculo, narração, domesticação. Rio de Janeiro: Azougue: 2005

COUTINHO, Eduardo; FURTADO, Jorge; XAVIER, Ismail. "O sujeito (extra)ordinário". In: $O$ Cinema do Real. LABAKI, Amir; MOURÃO, Maria Dora (org.) São Paulo; CosacNaify, 2005. 
COUTINHO, Eduardo; BRAGANÇA, Felipe (org.). Eduardo Coutinho. Rio de Janeiro: Azougue, 2008.

DAHLET, Patrick. "Dialogização enunciativa e paisagens do sujeito". In: BRAIT, Beth (org.). Bakhtin - dialogismo e construção do sentido. Campinas: Ed. UNICAMP, 2008.

DAMIÃO, Carla Milani. Sobre o declínio da "sinceridade" - Filosofia e autobiografia de Jean-Jacques Rousseau a Walter Benjamin. São Paulo: Loyola, 2006.

DANEY, Serge. A rampa - Cahiers du Cinéma 1970-1982. São Paulo: Cosac Naify, 2007.

DA-RIN, Silvio. Espelho partido: tradição e transformação no documentário. Rio de Janeiro: Azougue, 2004.

DEBRAY, Regis. Vida e morte da imagem: uma história do olhar no Ocidente. Petrópolis: Vozes, 1993.

DEBORD, Guy. A Sociedade do Espetáculo. Rio de Janeiro: Contraponto, 2000.

DELEUZE, Gilles. "O esgotado". In: Sobre teatro: Um manifesto de menos; O esgotado. Rio de Janeiro: Jorge Zahar, 2010.

"Carta a Serge Daney: otimismo, pessimismo e viagem" e "Três questões sobre seis vezes dois (Godard)". In: Conversações. São Paulo: Ed.34, 2000.

"Post-Escripum sobre as sociedades de controle". In: Conversações. São Paulo: Ed. 34,2000 .

"As potências do falso". In: A Imagem-Tempo. SP: Editora Brasiliense, 2005.

."O que é um dispositivo?". In: O Mistério de Ariana. Lisboa: Vega, 1996.

"A imanência: uma vida". In: Educação e realidade. n. 27, v. 2, p. 10-18, jul/dez.

2002.

.A Lógica do Sentido. São Paulo: Perspectiva, 2003.

Foucault. São Paulo: Brasiliense, 2005.

;GUATTARI, Felix. "Postulados da lingüística". In: Mil Platôs, Vol.II. São Paulo: Ed.34, 1995.

;GUATTARI, Felix “Ano zero: rostidade”. In: Mil Platôs, Vol.III. São Paulo: Ed.34, 1997.

Alvim, 2003.

;GUATTARI, Felix. Kafka: por uma literatura menor.Rio de Janeiro: Assírio e

;PARNET, Claire. "Da superioridade da literatura anglo-americana". In: Diálogos.

São Paulo: Escuta, 1998

DESCARTES, René. Descartes, Vida e Obra. Coleção Os Pensadores. São Paulo: Ed. Nova Cultural, 2004. Trad. Bento Prado Jr.

DETIÈNNE, Marcel. Os mestres da verdade na Grécia arcaica.Rio de Janeiro: Jorge Zahar, 1993.

DIDI-HUBERMAN, George. Images malgré tout. Paris: Les Éditions de Minuit, 2003. . Cuando las imágenes toman posición. Madrid: A. Machado Libros, 2008.

."La condition des images - entretien avec Frédéric Lambert et François

Niney". In: AUGÉ, Marc; DIDI-HUBERMAN, Georges; ECO, Humberto (orgs.) L'expérience des images. Paris: INA Éditions, 2011.

DUBOIS, Philippe. Cinema, Vídeo, Godard. São Paulo: Cosac Naify, 2003.

EDUARDO, Cléber. "Subjetividade: modo ou moda?" e "Obra em processo ou processo como obra?". In: EDUARDO, Cléber; VALENTE, Eduardo; VIEIRA, João Luiz (Orgs.) "Cinema 
brasileiro anos 2000, 10 questões" (catálogo da mostra homônima). Rio de Janeiro/São Paulo: Centro Cultural Banco do Brasil, 2011.

."O 'modelo egológico' no documentário brasileiro: a individualização pela rentabilidade cênica em Estamira e A pessoa é para o que nasce". Dissertação de mestrado apresentada ao Programa de Pós-Graduação em Ciências da Comunicação, ECA / USP, 2011.

(Org.) "Baseado em caso real - filmes brasileiros, histórias reais" (catálogo da mostra homônima). Brasília: Centro Cultural Banco do Brasil, 2009.

."Subjetividade mediada:_entre a classe social e a família universal". Revista

Cinética, mar., 2007. Disponível em: http://www.revistacinetica.com.br/santiagocleber.htm

."Pan-Cinema Permanente: tudo é efeito". Revista Cinética, abril de 2008.

Disponível em: http://www.revistacinetica.com.br/pancinema.htm

“Objetos sujeitos?". Revista Cinética, maio de 2008. Disponível em:

http://www.revistacinetica.com.br/docpersonagem.htm

EHRENBERG, Alain. L'individu incertain. Paris: Hachette, 1995.

O culto da performance - da aventura empreendedora à depressão nervosa.

São Paulo: Idéias e Letras, 2010.

ESCOREL, Eduardo. "Quatro ou cinco dilemas". O Estado de S. Paulo, Caderno 2, 24 de julho de 2005.

FELDMAN, Ilana. "Do declínio da intimidade aos novos regimes de visibilidade". Pacific textos para debate. Recife: Funcutura / Fundarpe /Símio filmes, 2011.

."Na contramão do confessional: o ensaísmo em Jogo de cena, Santiago e Pan-

cinema permanente." In: MIGLIORIN, Cezar (Org.) Ensaios no real. Rio de Janeiro: Azougue, 2010.

"A indeterminação sob suspeita no cinema brasileiro contemporâneo: os distintos casos de Filmefobia e Pan-Cinema permanente". In: Revista Galáxia, São Paulo, n. 20, p. 121133, dez. 2010.

"O cinema brasileiro contemporâneo". Revista CULT, Ano 13, 151, Dossiê "Os rumos da cultura no Brasil", out., 2010.

."A vida em cena: vida-produto, vida-lazer, vida-trabalho, vida-performance". In: Ciberlegenda - revista do Programa de Pós-Graduação em Comunicação da Universidade Federal Fluminense, Edição 22, $1^{\circ}$ sem. 2010. Disponível em: http://www.proppi.uff.br/ciberlegenda/vida-em-cena

"A imagem como ausência - sobre As Cartas Psicografadas por Chico Xavier, de Cristiana Grumbach (Brasil, 2010)". In: Revista Cinética, dez. 2010. Disponível em: http://www.revistacinetica.com.br/cartaschico.htm

. "Na contramão do confessional: o ensaísmo em Santiago, de João Moreira Salles, e Jogo de cena, de Eduardo Coutinho". In: Devires - cinema e humanidades, Belo Horizonte, v. 5, n. 2, out., 2009.

"Moscou: do inacabamento ao filme que não acabou". Revista Cinética, abril de 2009. Disponível em: http://www.revistacinetica.com.br/moscouilana

.O apelo realista". In: Revista FAMECOS, "Dossiê Menções de Destaque Compós 2008", Porto Alegre, n.36, ago. 2008. Disponível em: http://revcom2.portcom.intercom.org.br/index.php/famecos/article/viewFile/5472/4970

."Santiago sob suspeita". Trópico. ago-set, 2007. Disponível em: http://pphp.uol.com.br/tropico/html/textos/2907,1.shl

"Reality show: um dispositivo biopolítico". In: Estéticas da biopolítica: audiovisual, política e novas tecnologias. Revista Cinética / Programa Cultura e Pensamento (MinC), 2008. Disponível em: http://www.revistacinetica.com.br/cep/ilana_feldman.htm

."Paradoxos do visível - reality shows, estética e biopolítica". Dissertação de mestrado apresentada ao Programa de Pós-Graduação em Comunicação da Universidade Federal Fluminense. Niterói, RJ: 2007. 
."Reality show: um paradoxo nietzschiano". In: Ciberlegenda, ano 8, n.16, dez/jan. 2006. Disponível em: http://www.uff.br/ciberlegenda/

FERÁL, Josette. "Performance e performatividade: o que são os Performance Studies?. In: MOSTAÇO, Eldécio; OROFINO, Isabel; COLAÇO, Vera (orgs.). Sobre a performatividade. Florianópolis: Letras contemporâneas, 2009.

FERRAZ, Maria Cristina Franco. "Teatro e máscara no pensamento de Nietzsche" e "O simulacro e suas implicações em Deleuze, Nietzsche e Kafka”. In: Nove variações sobre temas nietzschianos. Rio de Janeiro: Relume Dumará, 2002.

"Verdade-mulher, amor e amizade em Nietzsche". In: AZEVEDO, Vânia Dutra

(Org.). Falando de Nietzsche. Ijuí: Unijuí, 2005, p. 115-129. Platão e as artimanhas do fingimento. Rio de Janeiro: Relume Dumará, 1999.

FOSTER, Hal. The Return of the Real. The avant-garde at the end of the century. Cambridge and London: MIT Press, 1996.

FOSTER, Lila Silva. "Filmes domésticos: uma abordagem a partir do acervo da Cinemateca Brasileira". Dissertação de mestrado apresentada ao Programa de Pós-Graduação em Imagem e Som da Universidade Federal de São Carlos. São Carlos: UFSCar, 2010.

FOUCAULT, Michel. História da sexualidade, vol.1, A vontade de saber. Rio de janeiro: Graal, 1997.

Fontes, 2005.

"Aula de 17 de março de 1976". In: Em defesa da sociedade. São Paulo: Martins ."Segurança, território, população" e "Nascimento da biopolítica". In: Resumo dos cursos do Collège de France (1970-1982). Rio de Janeiro: Jorge Zahar, 1997.

."A vida, a experiência e a ciência". In: MOTTA, M. (org.) Ditos e Escritos III. Rio de Janeiro: Forense, 2004.

Microfísica do poder. Rio de janeiro: Graal, 2000.

."O que é um autor?". In: Ditos e Escritos, vol. III, Rio de Janeiro: Forense, 2003.

."De outros espaços". Conferência proferida no Cercle d'Étude Architecturale, em 1967. Domínio público: http://www.ufrgs.br/corpoarteclinica/obra/outros.prn.pdf

FRANCE, Claudine de. Cinema e antropologia. Campinas: Ed. UNICAMP. 1999.

FRANÇA, Andréa. "O documentário entre a cena do tribunal e a cena do teatro". Trabalho apresentado ao XVIII Encontro Anual da COMPÓS, PUC-MG, Belo Horizonte/BH, 2009.

. "O cinema, seu duplo e o tribunal em cena". Trabalho apresentado ao XVII Encontro

Anual da COMPÓS, UNIP, São Paulo/SP, 2008.

FREIRE, Marcius. “A questão do autor no documentário". In: Significação - revista brasileira de semiótica. São Paulo: Annablume, n.24/2005.

GABLER, Neal. Vida, o filme. São Paulo: Companhia das Letras, 1999.

GAGNEBIN, Murielle; LIANDRAT-GUIGNES, Suzane (orgs.). L'essai et le cinema. Paris: Champ Vallion, 2004.

GERVAISEAU, Henri Arraes. "O abrigo do tempo: abordagens cinematográficas da passagem do tempo e do movimento da vida dos homens". Tese de doutorado apresentada ao Programa de Pós-Graduação em Comunicação e Cultura da Universidade Federal do Rio de Janeiro. Rio de Janeiro: UFRJ, 2000.

GOMBRICH, Hans Ernst. Arte e ilusão. São Paulo: Martins Fontes, 2007. 
GONÇALVEZ, Marco Antônio. O real imaginado - etnografia, cinema e surrealismo em Jean Rouch. Rio de Janeiro: Topbooks, 2008.

GORZ, André. O imaterial - conhecimento, valor e capital. São Paulo: Annablume, 2005.

GRANGE, Marie-Françoise. L'autoportrait en cinéma. Rennes, FR: PUR Éditions, Presses Universitaire de Rennes, 2008.

GUIMARÃES, César. "A singularidade como figura lógica e estética no documentário". In: Revista Alceu, vol.07, n.13, jul./dez. 2006, p.38 a 48.

"O retorno do homem ordinário do cinema". In: Revista Contemporânea vol.03, No.02, dezembro de 2005 - revista de Comunicação e Cultura do PÓSCOM, UFBA. ;LEAL, Bruno. "Experiência estética e experiência mediada". Trabalho apresentado ao GT "Estéticas da comunicação", na XVI Compós, realizada na UTP, CuritibaPR, 2007.

.Comum, ordinário, popular: figuras da alteridade no documentário brasileiro contemporâneo". In: MIGLIORIN, Cezar (org.). Ensaios no Real. Rio de Janeiro: Azougue, 2010.

.Documentário, testemunha do presente". In FURTADO, Beatriz (org.) Imagem contemporânea - cinema, TV, documentário... vol. I. São Paulo: Hedra, 2009.

."Um dia na vida do outro espectador". In: Revista Devires, Belo Horizonte, v. 7, n. 2, p. 132-138, jul/dez 2011.

;CAIXETA, Rubens. "Pela distinção entre ficção e documentário (provisoriamente)". In: COMOLLI, Jean-Louis. Ver e poder: a inocência perdida - cinema, televisão, ficção, documentário. Belo Horizonte: UFMG, 2008.

;GUIMARÃES, Victor. "Da política no documentário às políticas do documentário: notas para uma perspectiva de análise". Revista Galáxia, São Paulo, n. 22, p. 7788, dez. 2011.

GUINSBURG, Jacob; FERNANDES, Silvia (orgs). O pós-dramático. São Paulo: Perspectiva, 2008.

GUMBRECHT, Hans Ulrich. Produção de presença - o que o sentido não consegue transmitir. Rio de Janeiro: Contraponto / Ed. PUC-Rio, 2010.

HOLANDA, Karla. "Documentário brasileiro contemporâneo e a micro-história". Devires, Belo Horizonte, UFMG, v. 2, n.1, p. 86-101, jan-dez, 2004.

HUIZINGA, Johan. Homo ludens. São Paulo: Perspectiva, 2008.

ILLOUZ, Eva. O amor nos tempos do capitalismo. Rio de Janeiro: Jorge Zahar, 2011.

JAGUARIBE, Beatriz. O Choque do Real - estética, mídia e cultura. Rio de janeiro: Rocco, 2007.

JOURNOT, Marie-Thérèse. Films amateurs dans le cinéma de fiction. Paris: Armand Colin, 2011.

KEHL, Maria Rita. Deslocamentos de feminino. Rio de Janeiro: Imago, 2008.

KLINGER, Diana. Escritas de si, escritas do outro - o retorno do autor e a virada etnográfica. Rio de Janeiro: 7Letras, 2007.

LEHMAN, Hans-Thies. O teatro pós-dramático. São Paulo: CosacNaify, 2007. 
LEJEUNE, Phillipe. O pacto autobiográfico. Belo Horizonte: UGMG, 2008.

LEVI, Giovanni. "Usos da biografia". In: FERREIRA, M.M. \& AMADO, J. (coord.) Usos \& abusos da história oral. Rio de Janeiro: Editora da Fundação Getulio Vargas, 1996.

LEVY, Tatiana Salém. A experiência do fora - Blanchot, Foucault e Deleuze. Rio de Janeiro: Relume Dumará, 2003.

LIMA, Luís Costa. Limites da voz - Montaigne, Schlegel. Rio de Janeiro: Rocco, 1983. . Persona e sujeito ficcional - pensando nos trópicos. Rio de Janeiro: Rocco, 1991.

LINS, Consuelo. O documentário de Eduardo Coutinho. Rio de Janeiro: Jorge Zahar, 2004. .Dear Doc: o documentário entre a carta e o ensaio fílmico". In: Devires, Belo Horizonte, v.3, n.1, jan-dez., 2006. .Tempo e dispositivo no cinema de Cao Guimarães". In: Devires, UFMG, Belo Horizonte, v.4, n.2, julh/dez. 2007. "Rua de Mão Dupla: documentário e arte contemporânea". In: MACIEL, Katia (org.) Trasncinemas. Rio de Janeiro: Contracapa, 2009, p. 327-340.

;CURSINO, Adriana. "O tempo do olhar: arquivos em documentários de observação e autobiográficos". In: Conexão - Comunicação e Cultura, UCS, Caxias do Sul, v.9, n.17, jan/jun. 2010.

;REZENDE, Luiz Augusto; FRANÇA, Andréa. "A noção de documento e a apropriação de imagens de arquivo no documentário ensaístico contemporâneo". Revista Galáxia, São Paulo, n. 21, p. 54-67, jun. 2011.

;"Do espectador crítico ao espectador montador: Um dia na vida, de Eduardo Coutinho". In: Revista Devires, Belo Horizonte, v. 7, n. 2, p. 132-138, jul/dez 2011.

;BLANK."Ruínas da intimidade: os 'objetos encontrados' de Péter Forgács". In: REBELlO, Patrícia; SAMPAIO, Rafael (Orgs.). Péter Forgács: arquitetura da memória. São Paulo / Rio de Janeiro / Brasília: Centro Cultural Banco do Brasil, 2012.

LINS, Consuelo; MESQUITA, Cláudia. Filmar o real - sobre o documentário brasileiro contemporâneo. Rio de Janeiro: Jorge Zahar, 2008.

"Crer, não crer, crer apesar de tudo - a questão da crença nas imagens na recente produção documental brasileira". Trabalho apresentado ao XVII Encontro Anual da Compós - GT Fotografia, Cinema e Vídeo. UNIP, São Paulo, SP, 2008.

LISPECTOR, Clarice. A paixão segundo GH. Rio de Janeiro: Rocco, 1998. . Água viva. São Paulo: Editora Círculo do Livro, 1976.

LOPES, Silvina Rodrigues. "Do ensaio como pensamento experimental". In: Literatura, defesa do atrito. Lisboa: Vendaval: 2003.

LORAUX, Nicole. Les mères en deuil. Paris: Seuil, 1990.

MACHADO, Arlindo. Pré-cinema e pós-cinemas. Campinas, SP: Papirus, 1997. .O filme-ensaio". In: Intermídias, edição 5 e 6, 2006. Disponível em: www.intermidias.com/miolo/cinema_home.htm

MAFFESOLI, Michel. O instante eterno: o retorno do trágico nas sociedades pós-modernas. São Paulo: Zouk, 2003.

MARTIN GUTIERREZ, Gregório (Ed.). Cineastas frente el espejo. T\&B: Madrid, 2008. 
MECCHI, Leonardo. "O cinema popular brasileiro do século XXI". In: HALLAK, Raquel (org.) Cinema sem fronteiras - 15 anos da Mostra de Cinema Brasileiro de Tiradentes (Reflexões sobre o cinema brasileiro 1998-2012). Belo Horizonte: Universo Produção, 2012.

MELLO, Christine. Extremidades do vídeo. São Paulo: Ed. Senac, 2008.

MÉNIL, Alain. "Entre utopie et héresie: quelque remarques à propôs de la notion d'essai". In: LIANDRAT-GUIGNES, Suzanne; GAGNEBIN, Murielle (orgs.) L'essai e le cinéma. Paris: Champ Vallon, 2004.

MESQUITA, Cláudia. "Retratos em diálogo - notas sobre o documentário brasileiro recente". In: Novos estudos CEBRAP, n.86, março 2010.

"O mundo como olhar". Texto apresentado no Seminário Cinema, Estética e Política, realizado pelo Programa de Pós-Graduação em Comunicação Social e pelo Grupo de Estudos Poéticas da Experiência da UFMG. Belo Horizonte, UFMG, abril de 2011.

MIGLIORIM, Cezar. "Documentário recente brasileiro e a política das imagens". In: MIGLIORIN, Cezar (org.) Ensaios no real. Rio de Janeiro: Azougue, 2010.

."Escritas da cidade em Avenida Brasília Formosa e O céu sobre os ombros". In:

ECO PÓS, revista do Programa de Pós-Gradução da Escola de Comunicação da UFRJ, Dossiê: Cidades midiáticas, volume 14 número 01, 2011.

."Pactos de inconstância: o devir-Tupinambá em Moscou e Aquele Meu Querido Mês de Agosto", 2010, inédito.

"Negando o conexionismo: Notas flanantes e Sábado à noite ou como ficar à altura do risco do real. Trabalho apresentado ao GT Estudos de Cinema, Fotografia e Audiovisual, da XVIII COMPÓS: Belo Horizonte/MG, 2009.

.A política no documentário". In: FURTADO, Beatriz (org.) Imagem

contemporânea - cinema, TV, documentário... vol. I. São Paulo: Hedra, 2009.

.O Dispositivo como estratégia narrativa". In:

http://www.fca.pucminas.br/ceis/kripticas1.asp

."Jogo de cena - de Eduardo Coutinho (2)". Disponível no blog "Polis + Arte", 2007, em: http://a8000.blogspot.com/2007/10/jogo-de-cena-de-eduardo-coutinho-2.html

MONDZAIN, Marie-José. Le commrce des regards. Paris: Seuil, 2003. . A imagem pode matar? Lisboa: Vega, 2009.

.Homo spectator. Paris: Bayard, 2007.

MONTAIGNE, Michel de. Confissões I. São Paulo: Nova Cultural, 2000.

MOSTAÇO, Eldécio. "Fazendo cena, a performatividade". In: MOSTAÇO, Eldécio; OROFINO, Isabel; COLAÇO, Vera (orgs.). Sobre a performatividade. Florianópolis: Letras contemporâneas, 2009.

NANCY, Jean-Luc. La mirada del retrato. Buenos Aires: Amorrortu, 2006 Au fond des images. Paris: Galilée, 2003.

NICHOLS, Bill. Introdução ao documentário. Campinas, SP: Papirus, 2005. "A voz do documentário". In: RAMOS, Fernão (org.). Teoria Contemporânea do Cinema - Documentário e Narratividade Ficcional, vol. II. São Paulo: Senac, 2005.

ODIN, Roger. Les film de famille. Usage privé, usage public. Paris: Meridiens Klinckieck, 1995.

OITICICA, Hélio. "Anotações sobre o Parangolé" e "Situação da vanguarda. In: Aspiro ao grande labirinto. Rio de Janeiro: Rocco, 1986. 
PELBART, Peter Pál. Vida Capital - ensaios de biopolítica. São Paulo: Iluminuras, 2003.

PIMENTEL, Mariana. "Fabulação: a memória do futuro". Tese de doutorado apresentada ao Programa de Pós-Graduação em Letras, Departamento de Letras, PUC-Rio, 2010.

PRADO Jr., Plinio Walder. "Confessions (III) - Structure du Double". Texto de apresentação do curso de mesmo nome, no âmbito da Faculdade de Filosofia da Universidade Paris 8, ocorrido em 2008/2009.

"O Impronunciável: Notas sobre um Fracasso Sublime". In: Remate de Males, Campinas, (9): 21-29, 1989.

."O evento Beckett". Revista Cult, n. 142, dez./2009, ano 12.

RAMOS, Fernão (Org). Teoria Contemporânea do Cinema - documentário e narratividade ficcional, vol. II. São Paulo. Senac, 2005.

. Mas afinal o que é mesmo documentário? São Paulo: Senac, 2008.

."A mise en scène do documentário". In: Cine Documentário, Número 4, Año 2011,

Argentina. Disponível em: http://revista.cinedocumental.com.ar/4/teoria.html

RANCIÈRE, Jacques. Malaise dans l'esthétique. Paris: Galilée, 2004.

. Le spectateur émancipé. Paris: La Fabrique, 2008.

.A partilha do sensível. Estética e política. São Paulo: Ed. 34, 2005.

."O efeito de realidade e a política da ficção". In: Novos Estudos, n. 86, março 2010.

ROSA, Guimarães. "O espelho". In: Primeiras histórias. Rio de Janeiro: Nova Fronteira, 1988.

. Grande Sertão: Veredas. Rio de Janeiro: José Olympio, 1982.

ROSSET, Clément. O princípio da crueldade. Rio de Janeiro: Rocco, 1989.

O real e seu duplo. Rio de Janeiro: José Olympio, 2008.

SAFATLE, Vladimir. Cinismo e falência da crítica. São Paulo: Boitempo, 2008.

. Lacan. São Paulo: Publifolha, 2009.

. "Confrontar-se com o inumano". Dossiê Jacques Lacan, revista Cult, 125, ano 11,

2008.

."O envelhecimento do moderno". Entrevista concedida a Juliano Gentile e Thais

Rivitti, em 05/01/2007. http://forumpermanente.incubadora.fapesp.br/portal/.rede/numero/revnumero6/

.“A paixão pelo real”. In: Suplemento Mais!, FSP, 30/11/2003.

SALLES, João Moreira. "O cinema inútil”. O Estado de S.Paulo, Caderno 2, 24 de julho de 2005.

SARAIVA, Leandro. "Big Brother Brasil e Edifício Máster: espetáculo e anti-espetáculo". In: Sinopse - revista de cinema, número 11, ano VIII, setembro 2006.

SARLO, Beatriz. Tempo passado - cultura da memória e guinada subjetiva. São Paulo: Cia das Letras; Belo Horizonte: Ed. UFMG, 2007.

SCHOLLHAMMER, Karl Erik. "À procura de um novo realismo - teses sobre a realidade em texto e imagem hoje". In: HEIDRUN, Olinto Krieger e SCHOLLHAMMER, Karl Erik (Orgs.) Literatura e Mídia. São Paulo: Loyola, 2002.

SCHWARTZ, Vanessa. "O espectador cinematográfico antes do aparato do cinema: o gosto do público pela realidade na Paris de fim-de-século". In: O cinema e a invenção da vida moderna. São Paulo: Cosac \& Naify, 2001. 
SELIGMANN-SILVA, Marcio. Adorno. São Paulo: Publifolha, 2003.

SENNETT, Richard. O declínio do homem público - as tiranias da intimidade. São Paulo: Cia das Letras, 2002.

SENRA, Stella. "Perguntar (não) ofende - anotações sobre a entrevista: de Glauber Rocha ao documentário brasileiro recente". In: MIGLIORIN, Cezar. Ensaios no Real. Rio de Janeiro: Azougue, 2010.

IV, dez. 2004.

"Interrogando o documentário brasileiro". In: Sinopse - Revista de Cinema, n 10, ano .Como animais que morrem". In: Devires - Cinema e Humanidades. UFMG, Belo Horizonte, v.4, n.01, 2007.

SEVERINO, Antonio Marcos Vieira. "Pequenas notas sobre o ensaio". In: Revista História UNISINOS, vol. 08, n.10, julh./dez., p. 97-106, 2004.

SIBILIA, Paula. O show do eu - a intimidade como espetáculo. Rio de Janeiro: Nova Fronteira, 2008.

. "O artista como performer: Dilemas do eu espetacular nas artes contemporâneas". In: LABRA, Daniela (Org.). Performance Presente Futuro, vol. II. Rio de Janeiro: Ed. Aeroplano e Oi Futuro, 2010; p.14-20. p. 115-118.

SIQUEIRA, Marília Rocha de. "O ensaio e as travessias no cinema documentário". Dissertação apresentada ao Programa de Pós-Graduação em Comunicação Social da Faculdade de Filosofia e Ciências Humanas da Universidade Federal de Minas Gerais, jun. de 2006.

STAM, Robert. "A fenomenologia do realismo". Introdução à teoria do cinema. São Paulo: Papirus: 2003. 1981. O espetáculo interrompido - literatura e cinema da desmistificação. RJ: Paz e Terra,

STAROBINSKI. Jean. "Peut-on défini l'Essai?". In: BONNET, Jacques (org.). Jean Starobinski. Collection cahiers pour un temps. Paris: Centre Pompidou, 1985. Montaigne em movimento. São Paulo: Cia. das Letras, 1993.

SZONDI, Peter. Teoria do drama moderno. São Paulo: Cosac Naify, 2001.

TEIXEIRA, Francisco Elinaldo (org.) Documentário no Brasil - tradição e transformação. São Paulo: Summus, 2004.

TODOROV, Tzvetan. "Os homens-narrativas" e "Introdução ao verossímil". In: Poética da Prosa. São Paulo: Martins Fontes, 2003.

VELLOSO, Silvia Pimenta. "O perspectivismo em Nietzsche". In: DANOVSKI, Débora; PEREIRA, Luiz Carlos. O que nos faz pensar. Cadernos do Departamento de Filosofia da PUCRio, set. 2004.

. Os abismos da suspeita - Nietzsche e o perspectivismo. Rio de Janeiro: Relume Dumárá, 2003.

TCHEKHOV, Anton. As três irmãs. São Paulo: Abril Cultural, 1982.

THOMPSON, John B. "Fronteiras cambiantes da vida pública e privada". In: revista Matrizes, ano 4, Nº 1, jul./dez. 2010, São Paulo, p.11-36. 
XAVIER, Ismail. O Discurso cinematográfico - a opacidade e a transparência. Rio de Janeiro: Paz e Terra, 2005. . O olhar e a cena - Melodrama, Hollywood, Cinema Novo, Nelson Rodrigues. São Paulo: Cosac\&Naify, 2003. "Ressentimento e realismo ameno", entrevista concedida a Mario Sérgio Conti. In: MENDES, Adilson (Org.) Ismail Xavier. Rio de Janeiro, Azougue, 2009.

.Teoria e história no estudo de cinema no Brasil, entrevista a Adilson Mendes". In: MENDES, Adilson (Org.) Ismail Xavier. Rio de Janeiro, Azougue, 2009.

;MENDES, Adilson (org.) Ismail Xavier. Rio de Janeiro, Azougue, 2009.

."O mundo tem as caras que pode ter". In: CEVASCO, Maria Elisa; OHATA, Milton

(Orgs.) Um crítico na periferia do capitalismo: reflexões sobre a obra de Roberto Schwarz. São Paulo: Companhia das Letras, 2007.

."El exemplar y lo contingente en el teatro de las evidencias", revista Pensamiento de los Confines v.25, Buenos Aires, 2009. "Character Construction in Brazilian Documentary Films: Modern Cinema, Classical Narrative and Micro-Realism". In: NAGIB, Lucia Nagib; MELLO, Cecilia (org.), Realism and the Audiovisual Media, Londres, Palgrave MacMillan, 2009.

. "Indagações em torno de Eduardo Coutinho e seu diálogo com a tradição moderna". In: MIGLIORIN, Cezar (org.) Ensaios no real. Rio de Janeiro: Azougue, 2010.

"Iracema: o cinema-verdade vai ao teatro". In: Devires - cinema e humanidades, n.1, vlo. 2, jan-dez.2004. Belo Horizonte: FAFICH/UFMG, 2004.

."Cinema e teatro". In: XAVIER, Ismail (org.) O cinema do Século. São Paulo: Imago, 1996.

."Corrosão social, pragmatismo e ressentimento: vozes dissonantes no cinema brasileiro de resultados". Novos estud. - CEBRAP [online]. 2006, n.75, pp. 139-155.

WEINRICHTER, Antonio. "Un concepto fugidio. Notas sobre el film-ensayo". In: WEINRICHTER, Antonio (org.) La forma que piensa. Tentativas en torno al cine-ensayo. Coleción Punto de Vista, Festival Internacional de Cine Documental de Navarra. Fondo de Publicaciones del Gobierno de Navarra, 2007.

.Hacia un cine de ensayo". In: Desvios de lo real. El cine de no ficción. T\&B: Madrid, 2005. (2a. Edición)

."Copy is right. Tres momentos fundantes de la poética de la apropiación audiovisual". In: Memorias y olvidos del archivo. Centro Altántico de Arte Moderno-Mudeo de Historia y Antropologia de Tenerife, 2010.

WOOD Jr., Thomas. "O culto da performance e o indivíduo S/A". In: EHRENBERG, Alain. $O$ culto da performance - da aventura empreendedora à depressão nervosa. São Paulo: Idéias e Letras, 2010.

ZIMMERMANN, Patricia. Reel families: a social history of amateur film. Bloomington Indianapolis: Indiana University Press, 1995.

ZIZEK, Slavoj. Bem-vindo ao deserto do Real. São Paulo: Boitempo, 2003. "Le Sujet Interpassif". In: La subjectivité à venir. Paris: Champs Flammarion, 2006.

ZUMTHOR, Paul. "Em torno da ideia de performance". In: Performance, recepção, leitura. São Paulo: Cosac Naify, 2007.

WILLIAMS, Raymond. Tragédia moderna. São Paulo: Cosac Naify, 2002. 